\title{
Some aspects of the patient after total gastrectomy : clinical studies on symptomatology, nutrient malasseimilation and medico-social performance after total gastrectomy
}

Citation for published version (APA):

Brägelmann, R. (1998). Some aspects of the patient after total gastrectomy : clinical studies on symptomatology, nutrient malasseimilation and medico-social performance after total gastrectomy. [Doctoral Thesis, Maastricht University]. [s.n.]. https://doi.org/10.26481/dis.19980925rb

Document status and date:

Published: 01/01/1998

DOI:

10.26481/dis.19980925rb

Document Version:

Publisher's PDF, also known as Version of record

Please check the document version of this publication:

- A submitted manuscript is the version of the article upon submission and before peer-review. There can be important differences between the submitted version and the official published version of record. People interested in the research are advised to contact the author for the final version of the publication, or visit the DOI to the publisher's website.

- The final author version and the galley proof are versions of the publication after peer review.

- The final published version features the final layout of the paper including the volume, issue and page numbers.

Link to publication

\footnotetext{
General rights rights.

- You may freely distribute the URL identifying the publication in the public portal. please follow below link for the End User Agreement:

www.umlib.nl/taverne-license

Take down policy

If you believe that this document breaches copyright please contact us at:

repository@maastrichtuniversity.nl

providing details and we will investigate your claim.
}

Copyright and moral rights for the publications made accessible in the public portal are retained by the authors and/or other copyright owners and it is a condition of accessing publications that users recognise and abide by the legal requirements associated with these

- Users may download and print one copy of any publication from the public portal for the purpose of private study or research.

- You may not further distribute the material or use it for any profit-making activity or commercial gain

If the publication is distributed under the terms of Article 25fa of the Dutch Copyright Act, indicated by the "Taverne" license above,

Download date: 26 Apr. 2023 


\section{Some Aspects of the Patient after Total Gastrectomy}

Clinical Studies on Symptomatology, Nutrient

Malassimilation and Medico-Social Performance after Total Gastrectomy 
Brägelmann, Robert ISBN 90-9011968-x

The scientific work was supported by grants from the pharmaceutical companies Astra Pharmaceutica BV, Tramedico BV, Yamanouchi Pharma BV, Novo Nordisk Farma BV and Novartis Pharma BV. 


\title{
Some Aspects of the Patient
}

\author{
after Total Gastrectomy
}

\section{Clinical Studies on Symptomatology, Nutrient}

\author{
Malassimilation and Medico-Social Performance
}

after Total Gastrectomy

\author{
PROEFSCHRIFT \\ ter verkrijging van de graad van doctor \\ aan de Universiteit Maastricht, \\ op gezag van de Rector Magnificus, \\ Prof. Dr. A.C. Nieuwenluijzen Kruseman, \\ volgens het besluit van het College van Decanen, \\ in het openbaar te verdedigen \\ op vrijdag 25 september 1998 om 14.00 uur
}

door

Robert Brägelmann

geboren op $\mathbb{1 2}$ november 1960 te Vechta, Duitsland 
Promotor

Prof dr RW Stockbrügger

\section{Co-promotor}

Dr. med. habil. U Armbrecht (Marbachtalklinik, Bad Kissingen)

\section{Beoordelingscommissie}

Prof dr G Kootstra, voorzitter

Prof dr H Abrahamsson (Universitet Göteborg, Sweden)

Prof dr P Pop

Prof dr ir WHM Saris

Prof dr JPMA Smout (Universiteit Utrecht) 
Aan: ming ouders 


\section{Contents}

Chapter I: Introduction and Aims of the Study 9

Chapter II: Patients and Methods 55

Chapter III: Nutrient Malassimilation Following Total Gastrectomy 75

Chapter IV: Total Gastrectomy: The influence of Preserved Duodenal Transit and of Pouch Reconstruction on Abdominal Symptoms, Nutrient Assimilation, and Medico-Social Functioning 95

Chapter V: The Effect of Pancreatic Enzyme Supplementation in Patients with Total Gastrectomy and Steatorrhoea 113

Chapter VI: The Influence of Rapid Oro-coecal Transit Time on Symptoms, Clinical Signs, and Nutrient Assimilation in Patients after Total Gastectomy 127

Chapter VII: Small Bowel Bacterial Overgrowth in Patients after Total Gastrectomy 147

Chapter VIII: Determinants of Medico-Social Functioning after Total Gastrectomy 165

Chapter IX: Coping Behaviour in Patients after Curative Total Gastrectomy 185 
Chapter X: General Discussion 197

Chapter XI: Summary and Concluding Remarks 211

Chapter XII: Samenvatting en Conclusies 217

Chapter XIII: Zusammenfassung und Kommentar 223

Dankwoord 229

Curriculum vitae 233 



\section{Chapter I}

\section{Introduction and Aims of the Study}

R Brägelmann 


\section{General Remarks}

\section{Stomach cancer incidence}

The annual incidence and mortality rates of gastric cancer as a whole are declining in most countries ${ }^{1.2}$, but stomach cancer is still the second most frequent cancer world-wide and a major cause of morbidity and mortality ${ }^{2,3}$. Table I.1 gives the age standardised incidence of stomach cancer for some countries ${ }^{3}$. The incidence of stomach cancer localised to the cardia on the other hand seems to be increasing ${ }^{3.5}$.

Table I.1 Age-standardised incidence rates of stomach cancer for selected countries

\begin{tabular}{lcc}
\hline Age-standarised incidence per $\mathbf{1 0 0 . 0 0 0}$ inhabitants & femalle & male \\
\hline Japan & 37 & 85 \\
Germany & 12 & 22 \\
Netherlands & 8 & 20 \\
Kuwait & 2 & 4 \\
\hline
\end{tabular}

adapted from Neugut ${ }^{3}$

\section{Therapeutic strategies}

Surgery is the only possibility of cure in resectable gastric carcinoma. The surgical options with curative intention most often consist of partial gastrectomy ${ }^{7-9}$, subtotal gastrectomy ${ }^{10.11}$, total gastrectomy ${ }^{12-19}$, and combined resection of stomach and adjacent organs ${ }^{12,20}$. Endoscopic mucosal resection ${ }^{21,22}$, endoscopic laser irradiation $^{22}$, laparoscopic wedge resection ${ }^{23}$, and pylorus-preserving gastrectomy ${ }^{24}$ may be of interest in selected patients. The increase in proximal stomach cancers will probably lead to an increased frequency of total or subtotal gastrectomies $s^{6,13,19}$. During gastrectomy, a D2 lymph node resection is performed most often ${ }^{8,9,25-28}$, although there still is some discussion about the benefit of $\mathrm{it}^{29-33}$. More exiended lymph node resection is under study ${ }^{34-36}$. Neoadjuvant $t^{37.38}$ and adjuvant chemotherapy ${ }^{37.40}$ is an additional option in patients with stomach cancer, whereas radiation therapy is experimental ${ }^{41}$.

\section{Survival}

Some authors state that survival after total gastrectomy has not improved at all in the last decades ${ }^{4,6,42}$. Most authors, however, suggest a longer postoperative survival which is related to improved surgical techniques ${ }^{8.16,27.43-48}$ and to better and earlier diagnosis of gastric cancer ${ }^{8,45.49-58}$ leading to percentages of potentially curative resections of stomach cancer ranging from 53 to $98 \% \%^{13,45,5 \%}$. Table 1.2 
gives reported survival rates in different countries. Although survival after gastreciomy for gastric cancer has improved, in the majority of patients stomach cancer is still found in an advanced stage and survival is therefore poor ${ }^{60}$. In a report by the American College of Surgeons in 1993 Wanebo reports $65 \%$ of the patients to have stage III or IV stomach cancer on diagnosis ${ }^{61}$. The low proportion of long-term survivors is one of the reasons why studies on metabolic problems after total gastrectomy are scarce.

Table 1.2 Five-year survival rates of gastric cancer patients

\begin{tabular}{lccc}
\hline Stage & United States & Germany & Japan \\
\hline IIA & $59 \%$ & $85 \%$ & $100 \%$ \\
IB & $44 \%$ & $69 \%$ & $89 \%$ \\
II & $29 \%$ & $44 \%$ & $72 \%$ \\
IIIA & $15 \%$ & $29 \%$ & $48 \%$ \\
IIIB & $9 \%$ & $18 \%$ & $29 \%$ \\
IV & $3 \%$ & $9 \%$ & $12 \%$ \\
\hline
\end{tabular}

data adapted from Maruyama"

\section{History of gastric reconstruction}

Since the first successful total gastrectomy by Schlatter in 1897 more than 50 different surgical approaches and types of reconstruction have been proposed for this operation in order to minimise post-operative complaints, to prevent weight loss, and to ensure the highest possible quality of life $\mathrm{e}^{62-64}$. One of the latest, an interposition of the ileocoecal segment as substitute after pylorus-preserving-near total gastrectomy, was described in March $1997^{65}$.

In 1897 Schlatter restored continuity of the alimentary tract in a patient with gastrectomy with an antecolic end-to-side oesophagojejunostomy (Figure I.1). His primary interest after the operation were nutrition and digestion in the agastric patient.

In 1908 Goldschwend used a Y'anastomosis and introduced Roux's principle in reconstruction after total gastrectomy to prevent alkaline reflux oesophagitis. Since then the Roux-en- $Y$ construction has been developed further during the years by several surgeons (Figure 1.2). 

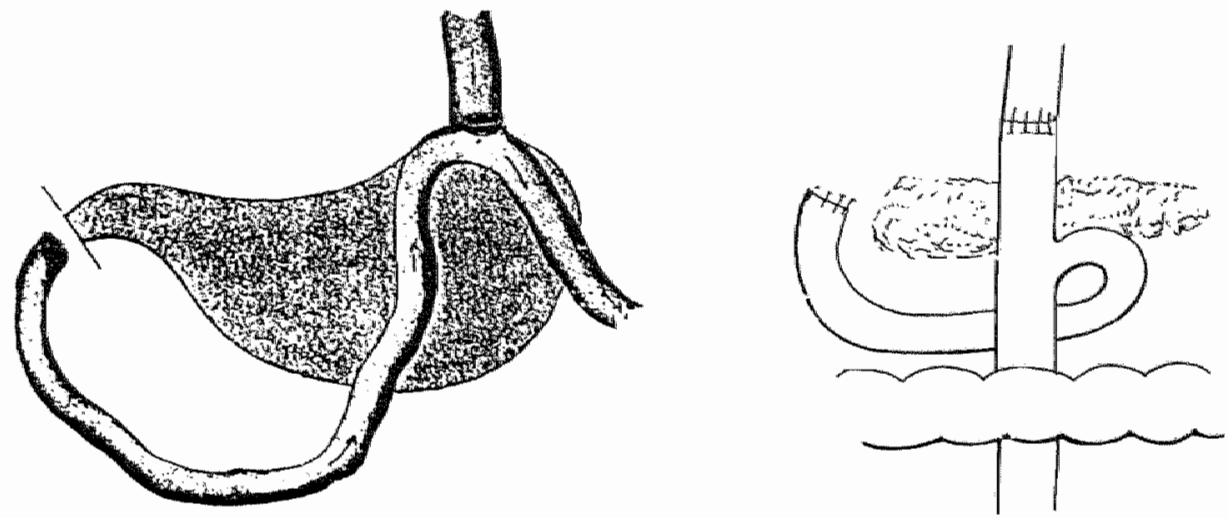

Figure 1.1

from Titte! ${ }^{62}$

Figure 1.2

The idea of jejunal interposition was first developed by Saccharow in 1939, whereas colonic interposition was reported by Hunicutt in 1949 for the first time. Various reconstructions with iso- and aniso-peristaltic jejunal- or colonic loops were described (Figures I.3 and I.4). The idea behind the concept of interposition was to preserve duodenal transit in order to improve digestion, whereas anisoperistaltic loops were introduced to slow down small bowel transit.

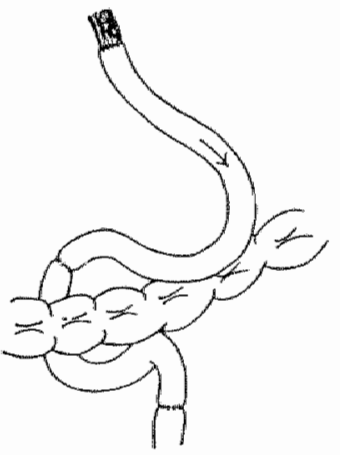

Figure 1.3

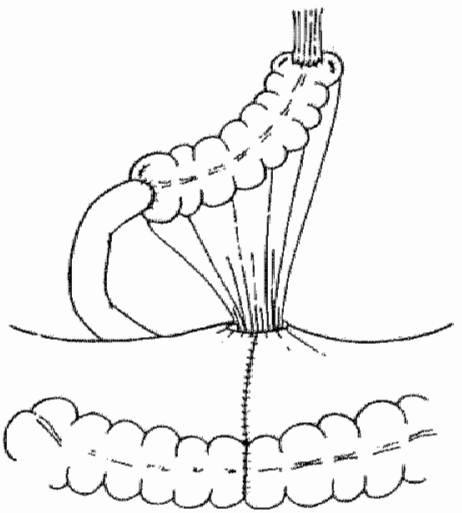

Figure 1.4 
To enlarge the gastric reservoir the concept of pouch-construction was introduced by Hoffmann in 1922. Like the other concepts, this idea was developed further in the following years (Figure I.5).

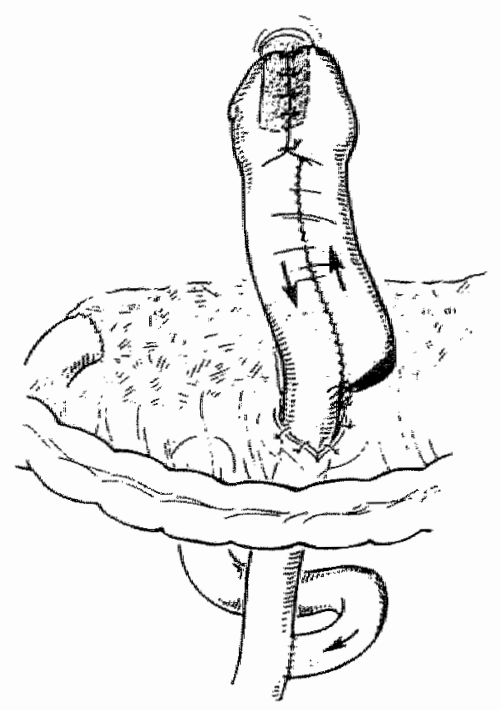

Figure I. .5 from Herfarth ${ }^{64}$

Functionally, the different types of operations can be divided into procedures which preserve a continuous duodenal transit and those with a duodenal bypass, both alternatives either with or without a construction of a reservoir as a stomach substitute (Figure 1.6).
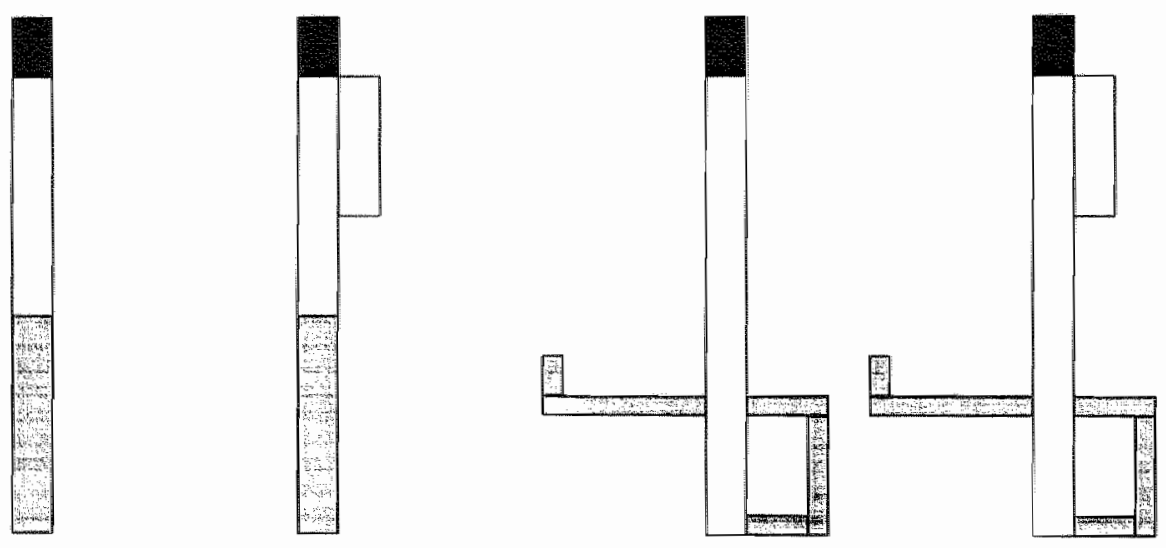

Figure 1.6 


\section{General Consequences of Gastric Resection}

\section{Symptoms}

After total gastrectomy, many patients suffer from a variety of abdominal complaints and systemic symptoms. The reported frequency of these symptoms in the literature varies widely, which partly is due to differences in symptom definition and assessment (Table I.3).

Table 1.3 Frequency of symptoms reported after total gastrectomy

\begin{tabular}{|c|c|c|c|c|c|c|c|c|c|c|}
\hline Anuthor & year & $\mathbf{n}$ & 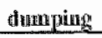 & nausera. & bloating & dyspespsia & sattiety & mellux & dysplatgia & vonutiting \\
\hline Kelly $y^{3}$ & 1953 & 26 & $\mathrm{ar}$ & 27 & nr & 46 & $\mathrm{nr}$ & $\mathrm{mr}$ & 23 & 27 \\
\hline Wizunitzer ${ }^{1 / 2}$ & 1966 & 25 & 76 & nr & $\mathrm{nr}$ & ar & arr & art & nIT & ur \\
\hline Adams & 1967 & 20 & 40 & $\mathrm{nin}^{\circ}$ & 75 & 50 & 5 & 60 & 10 & 5 \\
\hline Bradlesy & 1975 & 10 & 30 & nur & 40 & 40 & 90 & 30 & 10 & 10 \\
\hline albe & 1987 & 15 & 40 & 13 & 50 & 20 & nir & 0 & $\mathrm{inr}$ & 40 \\
\hline Herfartha & 1987 & 20 & 0 & $\mathbf{n}$ & $\mathrm{wr}$ & uir $\mathbf{r}$ & 10 & 20 & 0 & $\mathrm{~m} r$ \\
\hline \multirow[t]{2}{*}{ Schlatg ${ }^{3 / 4}$} & 1988 & 23 & 13 & ur & ur & ur & 91 & 13 & 0 & min \\
\hline & & 10 & 45 & $\operatorname{ur}$ & $\mathrm{nr}$ & $\mathrm{nr}$ & 82 & 45 & 9 & lar \\
\hline Millolic & 1989 & 20 & 35 & $\mathrm{ur}$ & ner & 25 & 15 & 25 & 25 & $\mathbf{m} r^{\circ}$ \\
\hline Miholic & 1990 & 41 & $25-29$ & $\mathrm{ur}$ & ar & 17.19 & 13 & 7.17 & $13-19$ & ar \\
\hline Pozzett? & 1990 & 23 & 36 & 17 & nr & 26 & 48 & 43 & nr & 9 \\
\hline Defbrisck & 1991 & $\begin{array}{c}11 \\
0\end{array}$ & 35 & 30 & 4.5 & 40 & $25-50$ & 30 & 14 & 22 \\
\hline \multirow[t]{2}{*}{ Scthonitz ${ }^{91}$} & 1994 & 15 & 50 & ur & nr & nr & 48 & 22 & irr & 60 \\
\hline & & 17 & 18 & ar & ur & $\mathbf{n r}$ & 60 & 50 & IIr & 30 \\
\hline Delbrick $^{\text {gz }}$ & 1994 & nr & un $r$ & 30 & 36 & 33 & 51 & 25 & 14 & 21 \\
\hline Anderson ${ }^{83}$ & 1995 & 57 & nr & 8 & wr & 7 & 8 & $\mathrm{nr}$ & 8 & 8 \\
\hline \multirow[t]{3}{*}{ Nalkane } & 1995 & 10 & 0 & $n$ & $\mathrm{nr}$ & urr & 14 & 14 & "17" & ur \\
\hline & & 10 & 0 & arr & $\mathrm{ar}$ & arr & 0 & 0 & aut & vir \\
\hline & & 10 & 0 & wir & nr & arr & 40 & 0 & air & nir \\
\hline range & & & 0.76 & $17-30$ & 36.75 & 7.50 & $0+91$ & $0-60$ & $0-25$ & 560 \\
\hline
\end{tabular}

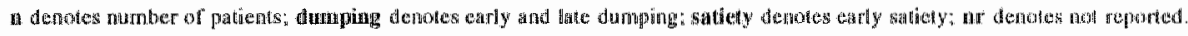

Early dumping, occurring in the first hour after meals in some patients after gastrectomy, causes systemic and abdominal symptoms. Systemic reactions are palpitations, fatigue, syncope, diaphoresis, dyspnoea, headaches, and flushing. Abdominal symptoms are epigastric fullness, diarrhoea, nausea, abdominal cramps, and borborygmia. An increase of more than 10 heartbeats/minute after an oral glucose challenge has been shown to be a good diagnostic criterion for early dumping ${ }^{66}$.

Late dumping, occurring in the first three hour after meals in some patients after gastrectomy, is characterised by perspiration, lack of concentration, hunger, 
decreased consciousness, and shakiness caused by hyperinsulinaemia and subsequent hypoglycaemia following fast delivery of meals to the intestine and rapid absorption of glucose.

Bloating, dyspepsia, and early satiety can be further symptoms of early dumping, but they are mentioned as independent entities by some authors. Early satiety is considered to be an anatomical capacity problem. The concept of pouchconstruction is based primarily on the idea of enlarging the volume of the gastric substitute.

Alkaline reflux is caused by reflux of bile acid and reflux of pancreatic and/or other intestinal juices causing anastomositis with in some cases dysphagia resulting from stenosis. Reflux oesophagitis after gastrectomy is best diagnosed by endoscopy. The frequency of oesophagitis after total gastrectomy is reported to be in the range of five to 35 percent $t^{67-69}$. Therapeutic strategies developed for this problem are the construction of a long Roux-en-Y loop 70 or of a pouch ${ }^{64}$. Vomiting after gastrectomy may be due to food retention in front of a stenosis or secondary to nausea.

\section{Malnutrition}

The primary problem of patients with stomach cancer is early diagnosis and curative resection leading to increased survival. In long-term survivors after gastrectomy malnutrition becomes of greater importance. It can be differentiated into overt macronutrient deficiency and subclinical micronutrient deficiency.

\section{Weight loss}

Most authors agree that weight loss is common after total gastrectomy, although in some studies no weight loss could be documented (Table I.4).

Comparing the results in the literature may have pitfalls, as study design and methods of reporting can vary. In Table $\mathbf{1 . 4}$ the results of ten studies with retrospective assessments and thirteen prospective longitudinal studies concerning weight loss are given. Weight loss since health comprises the pre-operative weight loss (including the pre-operative malnutrition and the possible catabolism due to malignancy) and the post-operative loss.

Overall, a weight loss of ten to 24 percent from pre-illness weight is reported. Most of the longitudinal studies point to a progressive weight loss after operation with a nadir and subsequent stabilisation of the body weight three to twelve months after operation (Table 1.4). Pre-illness weight is, however, hardly ever reached again. 
Table 1.4 Weight loss after cotal gastrectomy

\begin{tabular}{|c|c|c|c|c|c|c|c|}
\hline \multirow[t]{2}{*}{ Author } & \multirow[t]{2}{*}{ year } & \multirow[t]{2}{*}{$n$} & \multirow{2}{*}{$\begin{array}{l}\text { follow-tup } \\
\text { mond has }\end{array}$} & \multirow{2}{*}{$\begin{array}{l}\text { study design } \\
\text { ilnogitudimal }\end{array}$} & \multicolumn{2}{|c|}{ weight loss sined } & \multirow[t]{2}{*}{ naterir at } \\
\hline & & & & & health & opertilan & \\
\hline Kelly ${ }^{7 / 2}$ & 1953 & 26 & 2.96 & no & 24 & & \\
\hline Bratdey & 1975 & 10 & $3-94$ & no & $25 \mathrm{~kg}$ & & \\
\hline $\operatorname{Basso}^{\mathrm{ati}}$ & 1985 & 22 & 30 & yes & & $5-15 \%$ & 3 months \\
\hline Cristallo $o^{2 / 4}$ & 1986 & 12 & 36 & $n 0$ & & 0 & \\
\hline "Troyde & 1987 & 38 & 6 & $y e s$ & $\Rightarrow 9 \mathrm{~s}$ & & 6 months \\
\hline Sategna Gridetu & 1989 & 27 & 27 & yes & $13.7 \%$ & & \\
\hline \multirow[t]{2}{*}{ Mitholici } & 1989 & 11 & 33 & no & $22 \%$ & & \\
\hline & & 9 & 38 & & 111 路 & & \\
\hline \multirow[t]{2}{*}{ Miholie ${ }^{79}$} & 1990 & 15 & 36 & no & 21 唯 & & \\
\hline & & 26 & 43 & & 12 & & \\
\hline Bonzetu & 1990 & 4.4 & 36 & yes & $16 \%$ & & 15 months \\
\hline Crucitent & 1990 & 16 & 48 & no & most lost & most gaincol & \\
\hline Curran & 1990 & 6 & 4.5 & yes & wrigh loss & 120 loss & \\
\hline Dellbrilek & 1991 & 110 & 36 & no & $16 \%$ & & 1 months \\
\hline \multirow[t]{2}{*}{ Miholic ${ }^{\text {» }}$} & 1991 & 30 & & yes: & $27 \%$ & & with nadir \\
\hline & & 31 & & & $23 \%$ & & \\
\hline Köhter"s? & 1992 & 38 & $12-36$ & no & $10-15 \%$ & & \\
\hline Tsuburaya & 1993 & 27 & 317 & no & $20 \%$ & & \\
\hline Delbrüuk ${ }^{63}$ & 1994 & ar & $\mathrm{n} r$ & no & 210 & & \\
\hline Puchs & 1995 & 46 & 36 & yes & $10 \%$ & & platcan \\
\hline \multirow[t]{3}{*}{ Nakane } & 1995 & 10 & 24 & yes & $18 \%$ & & 6 mordhs \\
\hline & & 10 & 24 & & $14 \%$ & & 6 monuhs \\
\hline & & 10 & 24 & & 22 哭 & & 12 monthis \\
\hline Liedmans & 1996 & 61 & $3-12$ & yes & $=7 \mathrm{~kg}$ & & \\
\hline Borzentio & 1996 & 27 & 24 & yes & $20 \%$ & & 6 months \\
\hline \multirow[t]{2}{*}{ Schwarz" } & 1996 & 24 & 6 & $y u s$ & $11 \%$ & & 3 monhs \\
\hline & & 36 & 6 & $y e s$ & $17 \%$ & & no nadie \\
\hline Liedmatn ${ }^{0.8}$ & 1907 & 65 & 12 & yes & $10.5 \%$ & & 6 mothis \\
\hline
\end{tabular}

n denotes number of patients

Body composition changes of patients after total gastrectomy have been described by Miholic ${ }^{91}$, Liedman ${ }^{98}$, Bisballe ${ }^{9 y}$, and Walther ${ }^{10 \%}$. All mentioned a decrease in the lat-mass, although Bisballe found this only in men whereas the women of his study showed a decrease of fat-free mass. Liedman attributes $90 \%$ of the weight loss after total gastrectomy to loss of body fat ${ }^{98}$.

\section{Steatorrhoea}

In 1898, one year after the first successful total gastrectomy, the first studies on 
steatorrhoea after total gastrectorny were published ${ }^{101,102}$. Since then various reports dealt with this subject, of which some are summarised in the following table (Table I.5).

The range of the reported fat malabsorption between the studies is rather wide extending from five to 50 percent of the intake, both in large and in small studies, pointing to a true wide range of fat malabsorption.

The studies of Schwart $z^{103}$ and Bradley ${ }^{74}$ deserve further comment. Both were welldesigned metabolic ward studies on a small number of patients. Whereas the absolute faecal fat output was directiy proportional to the intake ${ }^{103}$, relative fat malabsorption was not correlated to intake $e^{7,103}$. Therefore studies giving faecal fat output in absolute figures without data on the intake are of limited use.

Walther is the only author providing data on fat malabsorption in patients before and after they were operated on. Two of his eleven patients had steatorrhoea preoperatively ${ }^{(0)}$. Post-operative steatorrhoea seems to normalise with increasing time after operation ${ }^{104}$. There are no reports showing a correlation of steatorrhoea and weight loss.

Table 1.5 Steatorrhoea after total gastrectomy

\begin{tabular}{|c|c|c|c|c|c|c|}
\hline \multirow[t]{2}{*}{ Autluor } & \multirow[t]{2}{*}{ year $\mathbf{r}$} & \multirow[t]{2}{*}{$\mathrm{n}$} & \multicolumn{3}{|c|}{ fat malabserption } & \multirow[t]{2}{*}{ comment } \\
\hline & & & mean & range & scale & \\
\hline Breilenbäch ${ }^{\text {nok }}$ & 1929 & 3 & $\sigma$ & & $\%$ & \\
\hline Patrisiog & 1943 & 1 & 7 & & $g_{1}$ & \\
\hline Kelly" & 1953 & 26 & 14 & $7-25$ & 㿥 & cakulated \\
\hline Bringallpor & 1956 & 6 & 8 & & \% & \\
\hline Sthwamet & 1956 & 7 & 21 & $14-33$ & 策 & \\
\hline Hays yols & 1960 & 4 & 15 & & 絭 & \\
\hline Adrans ${ }^{7 n}$ & 1967 & 20 & & $12-21$ & 嫼 & \\
\hline Pischermantent & 1967 & 12 & & $25-79$ & 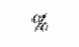 & calculated \\
\hline Bradiey & 1975 & 10 & 17 & $5-50$ & $\%$ & \\
\hline Brathey & 1977 & 5 & 19.2 & & 䗋 & \\
\hline Gulkin & 1979 & 12 & 13 & & w & \\
\hline Horfarth & 19.87 & 20 & 30 & $2-70$ & $\mathrm{~g} / \mathrm{d}$ & from thetare \\
\hline Sittengta Guiderti & 1989 & 27 & 37 & & $w$ & \\
\hline Walther & 1989 & 11 & 36 & & 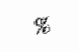 & \\
\hline Curran & 1990 & 6 & 23 & & $\%$ & calculated \\
\hline
\end{tabular}

at denotes mombar of pationas: 


\section{Anaemia}

Data on the prevalence of anaemia after gastrectomy varies and correlates with time past operation ${ }^{112 \cdot 117}$. The degree of anaemia is moderate most of the time, as can be seen in Table 1.6.

Iron deficiency was described in patients with gastrectomy as early as $1943^{\text {tan }}$. Most of the authors, however, evaluated patients with partial gastrectomy. Hobbs described iron deficiency anaemia in $50 \%$ of the patients, but also symptomatic sideropenia in $23 \%$ of the non-anaemic males ${ }^{1 / 2}$. In a prospective longitudinal study in patients with partial gastrectomy without iron supplementation Tovey ${ }^{1 / 8}$ found an iron deficiency in $60 \%$ of his patients after the first decade. The development of the iron deficiency was positively correlated with the time past operation and reached a prevalence of $90 \%$ for women and $70 \%$ for men during the third decade. There are authors, however, who found no difference in pre-operative and postoperative iron stores ${ }^{119}$. Amaral et al, report an iron deficiency in $47 \%$ of his patients after gastric exclusion for morbid obesity whom he followed over 33 months ${ }^{117}$.

It has been suggested by many authors that impaired iron absorption is the main reason for iron deficiency after gastric surgery ${ }^{71,106,112.114 .115,120.121}$. In achlorhydria, as after total gastrectomy, the inorganic ferric iron $\left(\mathrm{Fe}^{3+}\right)$ is not converted into the absorbable ferrous state $\left(\mathrm{Fe}^{2+}\right)^{106}$. Furthermore, the duodenum, which is the main resorption site for iron, is either rapidly passed ${ }^{122}$ or bypassed ${ }^{120}$, and liberation of food-bound iron is decreased due to lack of proteolysis ${ }^{120}$. Some investigators, however, could not find any difference in iron absorption ${ }^{123}$ or found impaired absorption in only few of the iron-deficient patients ${ }^{109}$. Gastro-intestinal bleeding resulting in iron deficiency can be caused by bacterial overgrowth of the small bowel $^{124}$ or oesophagitis and/or anastomositis ${ }^{114.115}$. Iron deficiency after gastrectomy or gastric exclusion responds well to oral iron supplementation ${ }^{13,119}$.

Table 1.6 Data on anamia in patients after partial or total gastrectomy or gastric exclusion surgery

\begin{tabular}{|c|c|c|c|c|c|c|c|}
\hline Author & year & $\mathbf{n}$ & $\begin{array}{l}\text { follow-up } \\
\text { (month) }\end{array}$ & median $\mathrm{Hb}$ & $\begin{array}{c}\text { anacruilat } \\
(\%) \\
\end{array}$ & $\begin{array}{l}\text { IDA } \\
(\%)\end{array}$ & $\begin{array}{l}\text { VBD } \\
(\%)\end{array}$ \\
\hline Kelly & 1953 & 26 & 2.96 & 13.5 & 41 & 8 & 35 \\
\hline Hobbsiz & 1961 & 242 & $36-60$ & $=13.5$ & $=50$ & all & nonc \\
\hline Fischermann & 1967 & 12 & $6-15$ & 13.9 & 17 & 17 & $n r^{\circ}$ \\
\hline Hilimat.18 & 1968 & 30 & $3-150$ & $=13.5$ & 47 & $\mathrm{mr}$ & nr" \\
\hline Adtanasist & $\| 968$ & 20 & $12-242$ & 10.6 & $\mathrm{nr}$ & 50 & 25 \\
\hline Toney:1"s & 1980 & 227 & $120 \mathrm{nr}$ & $\mathrm{nr}$ & 40 & all & $\mathrm{nr}$ \\
\hline Walter"s & 1984 & 17 & $12-192$ & $\mathrm{nr}$ & $n r^{\circ}$ & ar & 6 \\
\hline Amatral ${ }^{5 / 7}$ & 1985 & 150 & 12.72 & $13.7^{\circ}$ & 37 & 49 & 39 \\
\hline
\end{tabular}

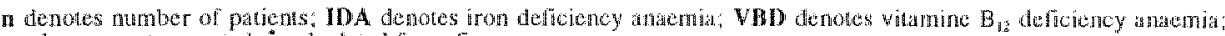
nr denotes not reported: " caloulated from ligure. 
Another potential factor leading to anaemia after gastric surgery is vitanin $\mathbf{B}_{12}$ deficiency ${ }^{86,113,169.119}$. As with iron deficiency anaemia, the prevalence of vitamin $B_{12}$ deficiency increases with time, but it takes longer to develop subnormall values. During the third decade after gastrectomy the prevalence of vitamin $B_{12}$ deficiency anaemia equals that of iron deficiency ${ }^{118}$. Vitamin $B_{12}$ deficiency after gastrectomy is due to the lack of intrinsic factor, but also to bacterial overgrowth ${ }^{118,125.127}$. Intramuscular vitamin $B_{12}$ supplementation in a dose of $1000 \mu \mathrm{g}$ every three month is thought to be an adequate treatment to prevent haematological and neurological complications of vitamin $B_{12}$ depletion ${ }^{119}$. Some authors recommend vitamin $B_{12}$ supplementation every two months ${ }^{116}$

Folic acid deficiency ${ }^{114,117,19}$ may be a third important cause of anaemia. It is due to a substantially lower intake and absorption than necessary ${ }^{17}$. However, in the presence of small bowel bacterial overgrowth, folic acid concentration in the serum may be abnormally high, due to bacterial synthesis ${ }^{128}$. Oral folic acid supplementation in a doses of five mg per day will correct a deficiency ${ }^{177,119}$.

\section{Osteopathy}

There is still a debate as to whether osteomalacia and/or osteoporosis can develop as a consequence of partial or total gastrectomy.

Maier demonstrated a $83 \%$ reduction of calcium absorption, a $70 \%$ reduction of 25-OH-vitamin D absorption, a serum parathyroid hormone level increased by $90 \%$ and a reduced bone mineral density in growing mini-pigs totally gastrectomised. He concludes that osteopathy is due to a secondary hyperparathyreoidism and calcium mobilisation from the bone ${ }^{129}$. Rumenapf et al. ${ }^{130}$ find osteopenia of the high turnover type but normal PTH levels in gastrectomised rats.

Bisballe reported $18 \%$ of the patients with partial or total gastrectomy to have osteomalacia and found that age, 25-(OH)-vitamin D levels, and the time since operation were determinants of osteomalacia after partial and total gastrectomy ${ }^{131}$. He found lower values for calcium, phosphor, and 25-hydroxycholecalciferol in gastrectomised patients with the same energy intake as healthy controls and concludes that this difference must be due to malabsorption of vitamin $D$ from the gut. He also states that supplementation with $10 \mu \mathrm{g}$ of vitamin $\mathrm{D}$ per day secures normal $25-(\mathrm{OH})-\mathrm{D}$ values in these patients ${ }^{99}$.

In a prospective longitudinal study 25 years after a partial gastrectomy Tovey 118 found osteomalacia in about $30 \%$ of the women and not in men. However, he used less sophisticated techniques for the evaluation than Bisballe. Krogsgaard compared patients operated on 20 years earlier for peptic disease with patients who had had peptic disease 20 earlier too but were not operated on. A significantly lower bone mineral content was found in patients with Billroth II-resection, but all values were still in the normal range. The number of bone fractures was not significantly higher in women with Billroth II than in controls. Bone mineral content correlated with 
the body mass index ${ }^{132}$.

Osteopathy may already start before gastrectomy. A relationship of calorie intake and bone mineral content has also been established for non-operated healthy elderly ${ }^{133}$. Decreased nutritional intake might be the reason that Kirchner found a pathologically low bone mineral density pre-operatively in $53 \%$ of a prospective cohort of 37 stomach cancer patients compared to age-matched healthy controls ${ }^{134}$.

\section{Vitamins, electrolytes, and protein}

The reports on the influence of gastrectomy on levels of fat-soluble vitamins are diverging. Some authors noted subnormal values for vitamin D, E, and A in normally nutritioned patients after gastrectomy ${ }^{99,20,135}$. Olbe ${ }^{\text {ps }}$, however, did not find any patient with subnormal vitamin A levels. A pre-operative vitamin A deficiency with disturbance of dark-adaptation in patients with gastric carcinoma was documented by Kirchner ${ }^{134}$.

Generally serum electrolyte status seems not to be altered by total gastrectomy ${ }^{74,103}$. Calcium levels might be lower due to vitamin D malabsorption ${ }^{135}$, although direct malabsorption has been described by some authors ${ }^{129}$. Although total gastrectomy decreases protein absorption by about $22 \%$, a positive nitrogen balance can be maintained ${ }^{74,103,110}$.

\section{Possible Causative Factors of Persistent Nutrient Malassimilation after Total Gastrectomy}

Possible causative factors of nutrient malassimilation can be malnutrition as a result of anorexia ${ }^{71.73 .74,86.88 .89,104,107.134 .136 .137}$, and maldigestion/malabsorption as a result of insufficient exocrine pancreatic functioning of any aetiology $74.901 .92,1000,109.110,111,133 \% .144$, rapid upper intestinal transit ${ }^{145-148}$, or upper intestinal bacterial overgrowth ${ }^{126,446,149-}$ 1.52. All these variables might be influenced by the type of surgical reconstruction and can act in concert. In the following, some of these possibilities will be discussed in more detail.

\section{Gastric resection and quantitative nutrient intake}

Adams $^{73}$, Crucitt $^{89}$, Brintnall ${ }^{107}$, and Roberts ${ }^{136}$ point to a too low calorie intake as the main problem after gastrectomy. Sategna Guidettio studied 27 patients and reports that $70 \%$ of them ate less than 31.7 kilocalories per $\mathrm{kg}$ body weight and day and $21 \%$ had a protein intake of less than $1 \mathrm{~g} / \mathrm{kg}$ body weight and day. Harju ${ }^{153}$ described symptom-induced low calorie intake in patients after total gastrectomy and Roux-en- $Y$ reconstruction. Other authors report a calorie intake in patients after gastrectomy, which is as high as in the normal heallthy 


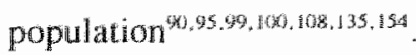

Evaluating these data, one has to keep in mind that a patient after gastrectomy may need a hypercaloric diet to regain and to maintain weight. Fredrix et al. described a small but significant increase in resting energy expenditure in gastric and colorectal cancer patients 1.5 years after operation ${ }^{135}$. In 1952 Everson recommended a diet of 50 kilocalories per kilogram body weilght and day for patients after total gastrectomy $^{156}$. Wechsler, however, considers diet with at least 40 kilocalories per kilogram body weight and day to be sufficient ${ }^{157}$. Liedman reported a lower frequency of weight loss in patients eating more than $150 \%$ of their basal metabolic requirements ${ }^{2}$. Bozzetti had a positive linear correlation of change in body weight and energy intake in a subpopulation of his study group ${ }^{96}$. Adaptive hyperphagia has been described in patients with malabsorption after small bowel resection ${ }^{158}$ and after total gastrectomy ${ }^{10 \$, 137}$. However, Leth et al. did not find any difference in body weight between patients meeting their energy requirements and those whose intake was considered to be unsatisfactory after a BI- or BII-resection ${ }^{3 *}$. Bradley found a higher than recommended calorie intake while the patients were admitted to a hospital and a $15 \%$ lower intake when the people were at home again. The number of patients examined, however, was only tent ${ }^{\text {th }}$.

Looking at the discrepancies among the studies mentioned above, there still is a need to describe energy intake in a larger number of patients after total gastrectomy and to examine, which factors determine it and what consequences nutrition has for the post-operative performance of the patient.

\section{Gastric resection and pancreatic function}

While there seems to be an agreement about the presence of steatorrhoea after partial and total gastrectomy, the pathophysiological mechanisms behind it are not clearly understood. Actually the number of patients evaluated for steatorrhoea after total gastrectomy is quite small in all studies, which compromises the usefulness of the data for the evaluation of causative factors.

In the discussion of the pathophysiology of steatorrhoea after gastric resection, one of the hypotheses is an inadequate secretion or insufficient action of pancreatic lipase. Assessment of pancreatic exocrine function after total gastrectomy is complicated: direct measurement of enzyme output is hindered by the Roux-en-Y reconstruction, and the PABA-test, the pancreolauryl test as well as determination of faccal chymotrypsin have all shown a low specificity ${ }^{159}$. Unfortunately the amino acid consumption test seems to have a low sensitivity ${ }^{\text {(6) }}, 16 !$, It is important to remember that in exocrine pancreatic insufficiency due to chronic pancreatitis pathologically increased faecal fat output occurs only when more than $90 \%$ of the lipase function have been lost ${ }^{162}$.

Nonpancreatic lipolysis by lingual ${ }^{16.3}$ and/or gastric lipase has been described. In 1993 Carriere et al. ${ }^{139}$ showed that gastric lipase digested $17.5 \%$ of the 
triglycerides in healthy volunteers. Deficiency of gastric lipase after total gastrectomy could be the first factor determining post-gastrectomy steatorthoea.

A second possible explanation of post-gastrectomy steatorrhoea is a decreased exocrine pancreatic enzyme output. This is referred to in the literature as primary pancreatic insufficiency, which actually is not a correct terminology as decreased enzyme output is secondary to surgery on a different organ. In 1952 Annis and coworkers reported the observation of a diminished pancreatic secretory response to meals in four of five dogs after gastrectomy. These findings could, however, not be reproduced in a similar study design ${ }^{140}$. In 1967 Fischermann et al. ${ }^{109}$ found a reduced output for amylase, lipase, trypsin, and chymotrypsin in twelve patients with total gastrectomy. Gullo examined twelve patients 20 months post-operatively with the secretin-caerulein test and found a reduction of the bicarbonate, lipase, and chymotrypsin output of $47,39,24 \%$, respectivelly. However, no correlation of decrease in lipase and degree of steatorrhoea was found; the lipase deficiency was modest, and Gullo concluded that "primary pancreatic insufficiency does not play, by itself, a major role in the pathogenesis of steatorhoea after total gastrectomy" $11 !$. Friess et al. ${ }^{142,143}$ studied exocrine pancreatic function in 15 patients after total gastrectomy preoperatively and three months post-operatively and found a significant decrease in volume-, trypsin-, chymotrypsin-, and amylase output of $76 \%, 89 \%, 91 \%$ and $72 \%$ respectively. Lipase, however, was not measured. The fact, that post-operative examination was only possible in about half of the patients due to technical difficulties with the anatomical situation underlines the problems with assessing pancreatic function after total gastrectomy. According to the authors, primary exocrine pancreatic insufficiency after total or subtotal gastrectomy is mediated by diminished levels of gastrin which has a trophic effect on the pancreas, and deficient triggering after destruction of the vagal nerve and the gastro-pancreatic nerves during lymph node dissection. It was, however, not proven that decreased pancreatic function parallels steatorrhoea.

There is, however, no agreement that the integral exocrine pancreatic function after total gastrectomy is decreased. On the contrary, in rals a reactive pancreatic hypertrophy and cellular hyperplasia after total gastrectomy had been described. Whereas the total enzyme content increased, the lipase content remained the same in the first weeks after gastrectomy: a phenomenon referred to as "enzyme dissociation" by Büchler ${ }^{164}$. However, four month after the operation this "enzymes dissociation" had vanished as lipase content has increased too ${ }^{165}$. This hypertrophy has been shown to be CCK-mediated ${ }^{166}$. However, it is not documented that the increase in intracellular enzyme content translates into higher enzyme secretion.

A third hypothesis explaining steatorrhoea after gastrectomy is an insufficient action/availability of normally excreted pancreatic enzymes. In the literature this is referred to as "secondary insufficiency" of the exocrine pancreatic function after 
total gastrectomy ${ }^{92,44,167,168}$. Possible reasons for this relative insufficiency are 1: bypass of the duodenum,

2. rapid transit of food through the small intestine with poor mixing of food and enzymes, also called pancreatico-cibal dys-or asynchrony, ${ }^{110,145,146,148,149}$,

3: negative feedback mechanisms of the ileum on the exocrine pancreas elicited by the presence of fat or carbohydrates ${ }^{36.170}$,

4: or bacterial overgrowth of the small intestine with bacterial degradation of pancreatic enzymes ${ }^{146,350}$

Based on the evident steatorrhoea and on the above mentioned hypotheses pancreatic enzyme supplementation has been tried after partial and total gastrectomy, but the data are scarce and not easy to interpret. After Billroth II partial gastrectomy pancreatic enzyme supplementation can reduce faecal fat excretion $^{13.171}$ and abdominal symptoms ${ }^{172}$. In a previous smaller study Armbrecht et al. could show in a small number of patients that pancreatic enzyme therapy improved fat assimilation also after total gastrectomy ${ }^{173}$. Bradley studied five patients with a Roux-en-Y construction after total gastrectomy with decreased levels of trypsin as well as lipase and delayed secretion of these enzymes compared with healthy controls. Supplementation with pancreatic enzymes resulted in an "improvement" of fat absorption, but the improvement is not quantified. He concludes that absolute or relative pancreatic insufficiency is present. However, no data are provided to characterise the patient or the control group. The attempt to control for the influence of bacterial overgrowth is insufficient and intestinal transii was not studied ${ }^{110}$. In spite of lacking scientific evidence, recommended dosages for pancreatic enzyme supplementation after total gastrectomy are 30,000 FIP lipase per meal, but this recommendation is based on experience with exocrine pancreatic insufficiency in chronic pancreatitis ${ }^{174}$.

The hypothesis of a secondary pancreatic insufficiency due to pancreatico-cibal asynchrony is also one of the reasons for the surgical concept of preserving the duodenal transit by use of a jejunal or colonic interposition. Some authors ${ }^{92,138,144}$ found less steatorrhoea in patients after Billroth I gastrectomy compared with Billroth II gastrectomy, providing indirect evidence for the hypothesis of relative pancreas insufficiency after gastrectomy.

In conclusion, although putative pancreatic exocrine insufficiency after total gastrectomy has been amply investigated, there is still no final agreement about its pathophysiological mechanisms and its relevance for the patient, mainly due to the methodological problems in assessing pancreatic function after the profound change of the anatomical situation. This leads to the question whether pancreatic enzyme supplementation after total gastrectomy is really of any benefit for the patient. 


\section{Gastric resection and different types of reconstruction}

During the last century surgeons have tried to optimise procedures of total gastric resection and post-operative reconstruction in order to minimise post-operative complaints, including weight loss, and to ensure the highest possible quality of life. Preservation of continuous duodenal transit should theoretically maintain normal entero-hormonal synergism better and preserve endocrine $e^{135-177}$ and exocrine pancreatic function compared with reconstruction based on a duodenal bypass ${ }^{73.94 .97 .138 .146}$. Furthermore, a higher degree of motility disturbances has been described in patients with duodenal bypass operations: 1) Faß et al. ${ }^{178}$ described a dissociation of the duodenal pacemaker and a second pacemaker in the gastric substitute of patients with a Roux-en-Y construction. Patients with an interposition after total gastrectomy - and without pacemaker dissociation - had a better weight gain $^{179}$. 2) Bassotti et al. ${ }^{180}$ also foster the idea of multiple pacemakers in the Rouxen- $Y$ limb interfering with normal motility resulting in a functional obstructive moment. 3) van der Mijle et al. ${ }^{181}$ showed that the Roux-limb stasis is indeed caused by motility disorders of the Roux-limb. Whereas the reason for the Rouxlimb stasis seems to be unravelled, it is still to be proven that Roux -limb stasis causes the so called "Roux-en-Y syndrome". Miedema et al. ${ }^{182}$ found motility abnormalities of the Roux-limb as frequent in asymptomatic patients with Rouxlimb stasis as in symptomatic patients.

The pouch-reconstruction was introduced to supply a gastric substitute. It was expected that patients could eat larger volumes at a meal, that the oro-coecal transit time would be protracted, and that the pouch-construction would serve as a barrier against entero-oesophageal reflux ${ }^{64,76,81,84,87,96,97,108,183-190}$.

Regarding the options of reconstruction one has to consider that preserving the duodenal transit or adding a pouch construction to a duodenal bypass operation increases operating time. Preserving the duodenal transit also adds one intestinal anastomosis and is not always applicable because of anatomical considerations ${ }^{\text {s? }}$.

Some authors have found patients with preserved duodenal transit to perform better compared with patients with duodenal bypass with regard to symptoms and weight gain $^{73,91.179}$ pointing to disturbed intestinal motility ${ }^{146.179,191}$, changed release of gastrointestinal hormones and of regulatory peptides ${ }^{175-i 77}$ and primary or secondary exocrine pancreatic insufficiency ${ }^{50,111.138 .141 .45 .168}$ after the bypass operation. Some authors, however, could not demonstrate any benefit of the continuous duodenal transit ${ }^{94}$.

The data regarding the benefit of a pouch-construction after total gastrectomy are not conclusive either. There are a number of prospective randomised studies comparing total gastrectomy with pouch-constructions with procedures without pouch. Troidl et al. ${ }^{87}$ reported a better appetice and weight development in 38 patients with pouch-construction. However, the energy intake of the patients was not quantified and a great difference in survival time might point to problems with 
comparability between the groups. Nakane et al ${ }^{34}$ found a higher food intake and less weight loss in patients with pouch, but patients were selected for the trial following unknown criteria, so that a patient bias cannot be excluded. Food intake was evaluated anamnestically, the number of patients per group was small, and the authors did not use a correction for multiple-group-comparison in the statistics. Schwarz et al. ${ }^{97}$ compared patients with duodenal preservation and pouches of two different sizes, Rodino-construction with pouches of two different sizes, and an ordinary Roux-en-Y construction (five groups with twelve patients each) and found a better quality of life in the group with duodenal preservation. Stier et al. ${ }^{192}$ assessed 18 patients with interposition with pouch and 18 patients with an Roux-en$Y$ construction without pouch. The symptom score of the first group was better. Schmitz et al. ${ }^{81}$ evaluated 39 patients with an interposition with or without pouch, and found a better quality of life in the former. Schlag et al. concluded that a pouch-construction is of use, but their study has many methodological problems ${ }^{76}$. In addition, there are retrospective studies ${ }^{183-187}$ and experimental studies ${ }^{193}$ showing benefit for a pouch-construction. However, in a prospective study by Liedman et al. on 89 patients $^{98}$, the patients with pouch had more postprandial problems than those without pouch and no benefit. Weight loss and changes in body composition were the same in both groups. In a prospective randomised controlled trial of 24 patients with a Roux-en- $Y$ reconstruction and 24 patients with a Roux-en- $Y$ construction with a Hunt-Lawrence-pouch Bozzetti found no difference in morbidity, mortality, emptying time of the loop or body weight after two years, and he concludes that there was no benefit of the pouch ${ }^{56}$. Tanaka reported more reflux problems in patients with pouches than in those without, but this study was very small ${ }^{194}$. De Almeida et al had similar results in a retrospective study ${ }^{195}$. Nakane et al. ${ }^{196}$ found a correlation of delayed emptying of the pouch construction with epigastric fullness, nausea, and vomiting. Furthermore, there are some experimental studies showing no benefit of a pouch-construction compared to a reconstruction without pouch ${ }^{197}$.

It remains to be evaluated whether or not preservation of the duodenal transit and/or pouch construction are of any influence on physical parameters and on postoperative performance of the patient after total gastrectomy.

\section{Gastric resection and small bowel transit times}

The passage of food from the oro-pharynx to the coecum is referred to as the orocoecal transit time (OCTT). During this time nutrients are mixed, portioned, digested, and absorbed.

Oro-coecal transit time can be assessed using breath tests with different substrates such as lactulose ${ }^{198.199}$ and standard meals ${ }^{200,201}$, or by scintigraphic investigations ${ }^{202-}$ 204. Whereas the average value for the oro-coecal transit time with standard meals $^{2002,201}$ and scintigraphic methods ${ }^{202-209}$ is about 4 hours, tests using lactulose 
result in more rapid small intestinal transit ${ }^{199.210}$.

Even in healthy individuals, the oro-coecal transit time is influenced by many variables, some of which are listed in Table 1.7.

Table 1.7 Variables possibly influencing oro-coecal transit time (OCTT) in patients after total gastrectomy

age

gender

qualitative and quantitative aspects of the diet

qualitative and quantitative tunction of other intestinal organs

tumour stage

type of reconstruction after gastrectomy

time since operation

According to Pilotto et al. ${ }^{211}$ oro-coecal transit time is age-dependent. Other authors, however, have not confirmed this finding $203,212,213$. Intestinal transit is not directly related to gender, but measured with the $\mathrm{H}_{2}$-breath test it is prolonged in the luteal phase of the menstrual cycle ${ }^{214}$. Increasing the volume of the meal delays oro-coecal transit time ${ }^{215}$, as does decreasing the volume of gastric secretion ${ }^{216}$. Proteolytic activity of the pancreas slows oro-coecal transi ${ }^{217}$. Short ${ }^{218}$ and medium chain fatty acids ${ }^{219}$ in the ileum accelerate oro-coecal transit, whilst long chain fatty acids prolong $\mathrm{it}^{218,220-223}$. This influence of long chain fatty acids on small bowel transit time could, however, not be shown by other authors ${ }^{219.224}$. It is remarkable that the small intestine adapts to extended duration of lipid exposure ${ }^{225.226}$. In postgastrectomy patient there are profound motility changes $8,106,178-181,191,192,227.230$. Tumour stage, type of surgical reconstruction, the time elapsed since operation and dietary habits are additional variables with a potential influence on small bowel transit time.

As a result of the multitude of factors influencing small intestinal transit time after total gastrectomy and of the small number of patients who survive operation long enough, reports on small bowel transit time after total gastrectomy are scarce and its relevance for the well-being of the patient is unclear.

Although the anatomical oro-coecal distance is shortened in gastrectomised patients, transit time is not necessarily faster than in healthy controls. Leth et al. examined 18 patients with Billroth I or Billroth II operation with a radiographic markerfollow-through-study and found a mean oro-coecal transit time of 150 minutes in both groups without any correlation to symptoms or nutrient mallabsorption ${ }^{138}$. In 1943 Farris reported a prolonged small bowel transit in patients after total gastrectomy applying a barium roentgenography ${ }^{106}$. Sategna Guidetti reported no abnormall small intestinal transit times in 27 patients after total gastrectomy ${ }^{88}$. 
Using a scintigraphic technique Pellegrini compared small bowel transit in ten patients after total gastrectomy and Roux-en-Y reconstruction with that in five healthy controls and found a significantly slower transit of the meal in the operated patients ${ }^{23 !}$. Miholic recorded a median small bowel transit time of 200 minutes in 61 patients after curative total gastrectomy with a scintigraphically controlled test meal. He found no correlation between small bowel transit and nutritional parameters!

In a small study using a radiographically controlled $\mathrm{H}_{2}$-breath test Armbrecht described four of eleven patients after total gastrectomy having an oro-coecal transit time of 60 minutes or less. A negative correlation of weight loss and oracoecal transit was found ${ }^{\mathrm{j} t t^{\prime}}$. Possible consequences of rapid small intestinal transit are disturbed mixing of food and pancreatic enzymes ${ }^{148,149}$ and impaired glucose absorption ${ }^{147,222,2,32}$. Morsiani reported a growth deficit in rats with rapid oro-coecal transit after total gastrectomy pointing to clinically relevant mutrient malassimilation ${ }^{2: 33}$.

In summary, up to now there is little information as to the frequency of rapid orocoecal transit time and its influence on symptomatology, nutrient malabsorption, and post-operative performance of patients after total gastrectomy.

\section{Gastric resection and bacterial overgrowth}

Under normal conditions the human upper and middle small bowel contains only a small number of bacteria. If more than $10^{5}$ collony forming units per $\mathrm{ml}$ of anaerobic or facultative anaerobic bacteria are found in a small bowel aspirate, one speaks of bacterial overgrowth ${ }^{234}$. Cultures of intestinal aspirates are the diagnostic "gold standard". Other diagnostic tests are based on breath-tests ${ }^{234-237}$ or urinary excretion $^{238}$ using miscellaneous substrates for the assessment of bacterial fermentation.

There are a number of aetiologic factors for small bowel bacterial overgrowth: structural lesions altering motility ${ }^{234}$, functional motility disorders ${ }^{239-241}$, an excessive load of bacteria through fistulas ${ }^{242}$ or the resection of the lleo-coecal valve $^{243}$, impaired gastric acid secretion ${ }^{24.245}$, immune deficiencies ${ }^{234}$, exocrine pancreas insufficiency $y^{234}$, age ${ }^{246}$, undernutrition itself $f^{126}$, or any combination of those.

In patients after total gastrectomy, lack of gastric acid and a profound alteration of motility are both immanent; exocrine pancreas insufficiency and malnutrition are possible. The combination of these factors results in a high risk of bacterial overgrowth.

Bacterial overgrowth can be asymptomatic $26.240 .247,248$. The term small bowel bacterial overgrowth syndrome, however, describes a varying clinical picture consisting of combinations of intermittent diarrhoea, abdominal symptoms such as meteorism, steatorrhoea and malabsorption of vitamins $86,115,150,249$ and/or macro- 
nutrients, weight-loss $\mathrm{s}^{234,237,241,250}$, gastrointestinal bleeding with iron deficiency anaemia ${ }^{124}$, and growth retardation in children ${ }^{25 !}$.

The diarrhoea is assumed to be the result of fat malabsorption and the osmotic load of unabsorbed carbohydrates. Another interesting hypothesis ${ }^{126}$ regarding the pathophysiology is that short chain fatty acids produced in fermentation processes by some intestinal bacteria ${ }^{252}$ cause rapid intestinal transit ${ }^{218}$. Steatorrhoea in small bowel overgrowth and consecutive malabsorption of fat soluble vitamins is probably due to a deficiency of conjugated bile acids ${ }^{1.50 .253}$ but possibly also to a toxic effect of deconjugated bile acids on jejunal mucosa ${ }^{25.255}$. Intraluminal bacterial utilisation of carbohydrates ${ }^{146.152}$ and diminished absorption ${ }^{256.257}$ are the causes of carbohydrate malabsorption. Protein malabsorption is mediated by intraluminal breakdown ${ }^{126}$, diminished brush border enzyme activity ${ }^{15 t}$ and active excretory $\operatorname{los}^{258}$. Vitamin $B_{12}$ deficiency in patients with small bowel bacterial overgrowth is caused by bacterial uptake of free or intrinsic factor-bound vitamin $\mathrm{B}_{12}{ }^{126}$. As can be seen from Table 1.8, the data regarding the frequency of small bowel bacterial overgrowth after gastric surgery are scarce and divergent. They need to be commented on.

Browning reported that ten days after truncal vagotomy 24 of 25 patients had bacteria in the small bowel ${ }^{260}$. Leth examined 18 patients after Billroth I- or Billroth II-gastrectomy with a $\mathrm{H}_{2}$-breath test and found no bacterial overgrowth at all ${ }^{138}$. Sategna Guidetti found no bacterial overgrowth in 27 patients after total gastrectomy $^{88}$. Lock, however, found bacterial overgrowth in 35 of $38(92 \%)$ patients after total gastrectomy ${ }^{263}$. However, he examined patients referred for endoscopy, and therefore a selection bias is possible.

Table 1.8 Frequency of small bowel bacterial overgrowth after gastric surgery

\begin{tabular}{|c|c|c|c|}
\hline Author & n & bacterial overgrowth in $\%$ of patients & with \\
\hline Ambrecht ${ }^{213}$ & 38 & 58 & achlorliydria \\
\hline Armbrecht ${ }^{2: 9}$ & 14 & 50 & achlorhydria \\
\hline Stockbrügeder & 19 & 42 & pernicious antemia \\
\hline Browning & 25 & 96 & truncal vagotomy \\
\hline Armbrecht ${ }^{2.9}$ & 10 & 90 & Billroth II \\
\hline Leth $^{1: 38}$ & 18 & 0 & Billrouth /Billroth II \\
\hline Bradley 110 & 10 & 90 & Billroth /Billrodn $\mathrm{V}$ \\
\hline Bjormeket ${ }^{261}$ & 22 & 100 & Billrodi /Billroth Ifl. \\
\hline Drasares & 43 & 30 & polyat-gastrectomy \\
\hline Sategnatis & 27 & 0 & total gastrectony \\
\hline $\operatorname{Lock}^{263}$ & 38 & 92 & totall gistrectony \\
\hline Bradlley ${ }^{74}$ & 10 & 100 & total gastrectomy \\
\hline
\end{tabular}

n denotes number of paients 
Bradley cultured anaerobes in all ten patients with total gastrectomy whom he examined ${ }^{74}$. In patients with an Billroth II resection faecal type flora was found in nine out of ten patients in gastric juice ${ }^{110}$. Bjorneklett found small bowel bacterial overgrowth in all 22 patients after a Billroth II resection. However, the situation in half of the healthy controls was the same ${ }^{261}$. Drasar assessed 43 patients with a partial gastrectomy and found small bowel bacterial overgrowth in 13 of them $(30 \%)^{262}$. In the gastric juice of patients with achlorhydria Armbrecht found faecal flora in $50-58 \%$ of the patients ${ }^{237,259}$ and Stockbrügger reported faecal type bacterial flora in duodenal biopsies in eight of 19 patients with pernicious anaemia ${ }^{245}$.

Therapy of post-surgical bacterial overgrowth is overshadowed by the risk of recurrence. Cyclic antibiotic treatment ${ }^{235,264}$, prokinetic $\mathrm{s}^{265}$, diet ${ }^{266}$, probiotics ${ }^{267,268}$ and surgery ${ }^{243}$ are possible therapeutic measures with varying success.

Looking at the possible sequelae for the patients, the frequency of small bowel bacterial overgrowth after total gastrectomy and its consequences for the patient need to be further elucidated.

\section{Gastric resection and quality of life}

Optimising quality of life in the gastrectomised patient has been recognised as a major point of concern ${ }^{7.269}$. Definitions of the quality of life are difficult. Often an operational approach is used ${ }^{270}$. Scores with emphasis on physical parameters like the Visick score ${ }^{271}$, the Karnofsky scale ${ }^{272}$, the Spitzer score ${ }^{273}$ and Sakamoto activity index ${ }^{274}$ have been used to evaluate quality of life after gastrectomy. They have been criticised for being more an assessment of health status than of quality of life $\mathrm{e}^{275,276}$. Therefore other scores encompassing physical, social, and emotional parameters were developed ${ }^{87,277,278}$.

After gastrectomy for malignancy, tumour recurrence has the highest influence on the quality of life ${ }^{274.283}$. However, untill now the influence of specific factors on the quality of life in tumour-free patients is investigational. Pre-operative patient- and tumour-characteristics, duodeno-oesophageal reflux disease $e^{63}$, small bowel bacterial overgrowth ${ }^{86.146,150}$, shortened oro-coecal transit time ${ }^{146}$, abdominal symptoms $^{83,87.186 .192}$, nutrient malassimilation and diarrhoea ${ }^{87,185}$, psychological ${ }^{269,275,281}$ and psycho-social factors ${ }^{28 !}$ are discussed as possible pathophysiological factors.

Most studies regarding quality of life after total gastrectomy compare the influence of different types of gastric reconstruction namely pouch construction, preservation of duodenal transit, or both ${ }^{81.83,87,94,97.183 .185-187,192.276 .282-286}$. An overview of these studies is given in Table I.9.

Whereas the pouch-construction seems to offer some better quality of life in most cases where it was studied, preserving duodenal transit does not seem to be of much influence. However, interpreting the results of the listed studies is difficult, because quite often the types of reconstruction differed in more than one parameter. 
Another way to look at the quality of life after total gastrectomy might be to take into account specific pre-and post-operative variables and determine their influence on medico-social functioning after surgery, hoping to point out fields where intervention might be useful. Such studies do not exist so far.

Table 1.9 Quality of Life after Total Gastrectomy

\begin{tabular}{|c|c|c|c|c|c|c|}
\hline Author & year & prospective study & \multicolumn{3}{|c|}{ reconstructions compared } & conclusion of the muthors \\
\hline Trond" & 1987 & yes & $\mathbf{P}$ & $v s$ & $\mathrm{OE}$ & pro pouch \\
\hline $\operatorname{Raab}^{2 \mathrm{BS}}$ & 1987 & nr & 1 & vs & ReY & no difference \\
\hline Roder & 1992 & no & $\mathrm{P}+\mathrm{PLI}$ & vs & OEI (-PLI) & pro pouch \\
\hline Schunitz & 1994 & yes & $I+P$ & vs & 1 & pro pauch \\
\hline Sitier $^{192}$ & 1994 & yes & $\mathrm{I}+\mathrm{P}$ & vs & $\operatorname{ReY}$ & pro interposition \\
\hline Fuchlisid & 1995 & yes & $1+P$ & vs & $\operatorname{ReY}+\mathrm{P}$ & no difference \\
\hline Buhlil $\left.\right|^{\text {ik? }}$ & 1995 & no & $\mathrm{TG}+\mathrm{P}$ & vs & PART & no difference \\
\hline Schwarz ${ }^{157}$ & 1996 & yes & $1+p$ & vs & ReY, ReY $+P$ & pro interposition $(+$ pouch $)$ \\
\hline Svedlund $^{286}$ & 1.997 & yes: & 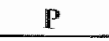 & us & OEL, PART & no difference \\
\hline
\end{tabular}

P denotes pouch: OEJ denotes oesophago-jejunostomy; I denotes interposition; ReY denotes sthndard Rouxen-Y, PLL denotes plication; PART denotes partial gastrectomy; bold letters denote what kind of reconstruction can be evalluated by the study

\section{Gastric resection and coping behaviour}

In addition to the somatic approach discussed above, psychological factors influencing the quality of life after the diagnosis and/or treatment of severe disease have been of increasing interest. Coping strategies are one facet of these factors.

Coping studies developed from the studies of stress reactions. Coping categories are not precisely defined, but different main coping styles have been described as "confrontative", "avoiding", "resigned", or a "non-dominant style"2\%? . Coping behaviour has been described as being influenced by gender ${ }^{288,289}$ and age ${ }^{20,2941}$ by some authors. The outcome of an operation or a therapy $y^{279,200,292}$, especially when compared to the subjective expectancies of the patient ${ }^{293}$, have been found to be of importance for coping behaviour. The ascribed meaning of symptoms ${ }^{294}$ and causal psychosocial attributions $^{\text {2\%5 }}$ will supposedly effect it. Coping strategies are not exclusively personal style $e^{296}$ but can be learnt ${ }^{297-302}$. There does not seem to be a direct correlation between educational level and coping responses ${ }^{200}$, but educational status is discussed as a mediating factor ${ }^{281}$. Some coping strategies are reported to correlate with better adjustment and less emotional distress than others $^{293,2953.302-305}$. The information about the cancer shatters the self-concept of the patient, but this is the prerequisite to start the coping process ${ }^{306}$. The positive influence of disease-related education on the patient's post-operative coping and subsequent performance is acknowledged by many authors ${ }^{295.300 \cdot 302,307.309}$. Personal 
interactive learning seems to be preferred by the majority of the patients ${ }^{310}$.

Whilst the importance of successful and unsuccessful coping strategies for the patient"s well-being are recognised, is not well understood what motivates the single patient to choose certain types of coping behaviour and to avoid others. The patient's personal psychological profile certainly has the most important impact on his choice of coping strategies, but a very intriguing finding in the study of coping behaviour is a certain disease specificity. Holland et al ${ }^{311}$ examined 107 patients with pancreatic cancer and 111 gastric cancer patients and found more depression, tension-anxiety, and anger in the first group. Patients with myocardial infarction or cancer seem to choose more often for a confrontative strategy than patients with arthritis $^{256}$. In a large multicentre trial Muthny et al. ${ }^{3 / 2}$ compared patients with myocardial infarction, cancer, renal dialysis, and multiple sclerosis. Depressive coping discriminated between the patients with multiple sclerosis, who more often showed depressive behaviour, and patients with myocardial infarction. Life satisfaction was higher in patients with myocardial infarction and cancer than in the two other groups; whilst a fighting spirit was considered the most helpful coping tool by cancer and multiple sclerosis patients, in patients with myocardial infarction it was trust in the doctors. Using the same questionaire as Muthny, Theissen ${ }^{3.3}$ reported a preference for certain coping strategies among a small group of patients after total gastrectomy. Disease-specific coping patterns might result from objective disease parameters, symptoms, physical stigmata, therapeutical requirements or peer-group reactions ${ }^{313}$. Reports, however, are not consistent ${ }^{304,306}$ and no correlation has been made between certain symptoms and coping strategies ${ }^{302}$. Svedlund et al. ${ }^{3 / 4}$ discuss the need for linking somatic factors to psychological performance after gastrectomy for gastric cancer.

As there is a difference in coping patterns between various disorders, it is tempting

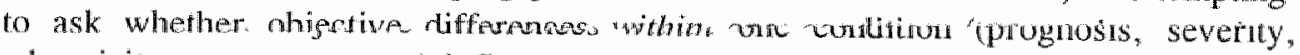
chronicity, symptoms, etc.) influence the choice of certain coping strategies. 


\section{Aims of the study}

The intentions of the following studies were:

1. To provide data on symptomatology and nutrient malassimilation of tumour-free patients after total gastrectomy (Chapter III).

2. To examine the pathophysiology of nutrient malassimilation and its influence on post-operative medico-social performance in tumour-free patients after total gastrectomy, with the following specific questions:

a. Are preservation of the duodenal transit and/or pouch construction of any influence on physical parameters and on post-operative performance of the patient after total gastrectomy? (Chapter IV)

b. Does pancreatic enzyme supplementation relieve symptoms and/or improve fat absorption in patients after total gastrectomy? (Chapter $\mathbf{V}$ )

c. What is the frequency and the clinical relevance of excessively rapid orocoecal transit in these patients? (Chapter VI)

d. What is the frequency of small bowel bacterial overgrowth after total gastrectomy and what are the consequences for the patient? (Chapter VII)

e. Is it possible to identify pre-, peri-, or postoperative factors influencing postoperative medico-social performance? (Chapter VIII)

f. Do coping patterns applied by patients after a potentially curative total gastrectomy for gastric malignancy show a disease-specificity, and is it possible to identify parameters of potential influence on the predilection of the patients for certain coping patterns. (Chapter IX) 


\section{References}

1. Parkin D. Laara E, Muir C. Estimate of the worldwide frequency of sixteen major cancers in 1980. Int J Cancer 1988;411;184-197

2. Davis DL. Hoel D, Fox J, Lopez A. Epidemiology: International trends in cancer mortality in France, West Germany, Italy, Japan, England and Wales, and the USA. The Lancet 1990;336:474-481

3. Neugut Al, Hayek M, Howe G. Epidemiology of Gastric Cancer. Semin OncolGastric Cancer 1996:23930:281-291

4. Diehj JT, Hermann RE, Cooperman AM, Hoerr SO. Gastric Carcinoma-A TenYear Review. Ann Surg 1983;198:9-12

5. Fortner JG, Lauwers GY, Thaler HT, Concepcion R, Friedlander-Klar H, Kher U, Maclean BI. Nativity, complications, and pathology are determinants of surgical results for gastric cancer. Cancer 1994;73:8-14

6. Korenaga D, Moriguchi S, Orita H, Kakeji Y, Haraguchi M, Maehara Y, Sugimachi K. Trends in survival rates in Japanese patients with advanced carcinoma of the stomach. Surg Gynecol Obstet 1992;174:387-393

7. Bozzeti F. Total versus subtotal gastrectomy in cancer of the distal stomach: facts and fantasy. Eur J Surg Oncol 1992;18:572-579

8. Breman MF, Karpeh MS Jr. Surgery for gastric cancer: The American view. Semin Oncol-Gastric Cancer $1996 ; 23: 352-359$

9. Maruyama K, Sasako M, Kinoshita T, Sano T, Katai H. Surgical treatment for gastric cancer: the Japanese approach. Semin Oncol-Gastric Cancer 1996,23:360368

10. Winkler $M$, Jentschura $D$, Winter $J$, Schwall GE. Results of surgical therapy of early stomach cancer. Zentralbl Chir 1995;120:795-799

11. Menke H. Morbidität und Letalität nach Operationen wegen Magenkarzinom. Ergebnisse einer prospektiven Untersuchung zur Bedeutung unterschiedlicher Risikolakıoren. Med Klin 1992;87:300-304

12. Maruyama $K$ Okabayashi $K$, Kinoshita $T$. Progress in gastric cancer surgery in Japan and its limits of radicality. World J Surg 1987:11:418-425

13. Meyer HJ, Jähne J, Wilke H, Pichlmayr R. Surgical Treatment of Gastric Cancer: Retrospective Survey of 1,704 Operated Cases With Special Reference to Total Gastrectomy as the Operation of Choice. Semi Surg Oncol 1991;7:356-364

14. Bandoh T, Isoyama T, Toyoshma $\mathbf{H}$. Total gastrectomy for gastric cancer in the elderly. Surgery 1991;109:136-142

15. Gouxi JL, Bloom E, Labbe F. Total versus subtotal gastrectomy for adenocarcinoma of the gastric antrum. Dig Surg 1994;11:58-63

16. lida $F$, Koike S, Koide N. Extended total gastrectomy for carcinoma of the cardia. Hepato-gastroenterology 1993;40:103-106

17. McNeer G. Bowden L. Booher R. McPeak C. Elective Total Gastrectomy for Cancer of the Stomach: End Results. Ann Surg 1974;180:252-256 
18. Xu L, Li Z, Zhang J, Sun C, Zhang Z, Ren H, Yu H. Total gastrectomy via thoracotomy for cancer of the cardia of fundus of the stomach. Chin Med Sci $1993 ; 8: 243-245$

19. Bitner $R$, Butters $M$, Ulich $M$, Uppenbrink $S$, Beger $H G$. Total gastrectomy. Updated operative mortality and long-term survival with particular reference to patients older than 70 years of age. Ann Surg 1996:224:37-42

20. Kodama I Takamiya $\mathbb{H}$, Mizutani $K$, Ohta J. Aoyagi $K$, Kofuji K, Takeda J, Shirouzu K. Gastrectomy with combined resection of other organs for carcinoma of the stomach with invasion to adjacent organs: Clinical efficacy in a retrospective study. J Am Coll Surg 1997; 184:16-22

21. Sano T, Kobori O, Muto T. Lymph node metastasis from early gastric cancer: endoscopic resection of tumour. Br J Surg 1992;79:241-244

22. Hiki Y, Shimao H, Mieno H, Sakakibara Y, Kobayashi N. Saigenji K. Modified Treatment of Early Gastric Cancer: Evaluation of Endoscopic Treatment of Early Gastric Cancers witly Respect to Treatment Indication Groups. World I Surg $1995 ; 19: 517-522$

23. Goln PMY, Alponat A, Mak K, Kum CK. Early International Results of Laparoscopic Gastrectomies. Surgical-Endoscopy-Ultrasound and Interventional Techniques 1997:11:650-652

24. Kodama $M$, Koyama K. Indication for pylorus-preserving gastrectomy for early gastric cancer located in the middle third of the stomach. World J Surg $1991 ; 15: 628-634$

25. Korenaga D, Baba $H$, Kakeji $Y$, Orita $H$, Haraguchi $M$, Maehara $Y$, Saku $M$, Sugimachi $\mathrm{K}$. Comparison of R1 and R2 gastrectomy for gastric cancer in patients over 80 years of age. J Surg Oncol 1991;48:136-141

26. Pacelli F, Doglietto GB, Bellatone R, Alfieri S, Sgadari A, Crucitti F. Extensive versus limited lymph node dissection for gastric cancer: a comparative study of patients. Br J Surg 1993;80:1153-1156

27. Roder JD, Böttcher K, Siewert JR, Busch R, Hermanek P, Meyer HI. Prognostic factors in gastric carcinoma. Result of the German Gastric Carcinoma Study. Cancer 1993;72:2089-2097

28. Harrison LE, Karpeh MS, Brennan MF. Extended lymphadenectomy is associated with a survival benefit for node negative gastric cancer. Gastroenterology $1997 ; 122: \mathrm{A} 1447$

29. Bonekamp IIJ, Songun I, Hermans, Sasako M, Welvaart K, Plukker JTM, van Elk P, Obertop H, Gouma DJ, Taat CW, van Lanschot J, Meyer S, de Graaf PW, won Meyenfeldt MF, Tilanus $H$, wan de Velde CJH. Randomised comparison of morbidity after D1 and D2 dissection for gastric cancer in 996 Dutch patients. The Lancet 1995:345:745-748

30. Robertson CS, Chung SC, Woods SD, Griffin SM, Raimes SA, Lau JT, Li AK. A prospective randomized trial comparing R1 subtotal gastrectomy with R3 total gastrecotmy for antral cancer. Ann Surg 1994;220:176-182 
31. Roukos D, Schmit-Mathiesen A, Encke A. Adenocarcinoma of the gastric antrum: does D2 total gastrectomy with splenectomy improve prognosis compared to D1 subtotal gastrectomy? A long-term survival analysis with emphasis on Lauren classification. Surg Oncol 1995;4:323-332

32. Bunt AMG, Hermans J, Smit VTHBM, van de Velde CJH, Fleuren GJ, Bruijn JA. Surgical/pathological-stage migration confounds comparisons of gastric cancer survival rates between Japan and western countries. I Clin Oncol 1995;13:19-25

33. Siewert JR. Invited commentary. World J Surg 1995;19:553

34. Wu CW, Hsieh MC, Lo SS, Wang LS, Hsu WH, Lui WY, Huang MH, P'eng FK. Morbidity and mortality after radical gastrectomy for patients with carcinoma of the stomach. J Am Coll Surg 1995;181:26-32

35. Kitamura M, Arai $K$. Iwasaki $Y$. Clinico-pathological studies and problems on paraaortic lymph node dissection--D4 dissection. Nippon-Geka-Gakkai-Zasshi 1996;97:302-307

36. Adachi $Y$, Mimori K, Mori M, Maehara Y, Sugimachi K. Morbidity after D2 and D3 gastrectomy for node positive gastric cancer. J Am Coll Surg 1997;184:240-244

37. Fukushima M. Adjuvant Therapy of Gastric Cancer: The Japanese Experience. Semin Oncol-Gastric Cancer 1996:23:369-378

38. Kelsen DP. Adjuvant and Neoadjuvant Therapy for Gastric Cancer. Semin OncolGastric Cancer 1996;23:379-389

39. Meyer $\mathrm{HJ}$, Jahne J, Wilke $\mathrm{H}$. Perspectives of surgery and multimodality treatment in gastric carcinoma. J Cancer Res Clin Oncol. 1993;119:384-394

40. Roder JD, Stein HJ, Böttcher K, Siewert JR. Surgical therapy for gastric cancer. J Infus Chemother 1995;5:97-103

41. Minsky BD. The Role of Radiation Therapy in Gastric Cancer. Semin OncolGastric Cancer 1996;23:390-396

42. Becker HD. Radikalitätsprinzipien beim Magencarcinom-eine kritische Betrachtung. Chirurg 1991;62:878-880

43. Gall FP, Altendorf A, Hermanek P, Gentsch HH. Chirurgische Therapie des Magenkrebses-Stagnation oder Fortschritte? Ergebnisse bei 2665 MagenkrebsPatienten. Fortschr Med 1982;100:1876-1882

44. Koga $S$, Kishimoto $H$, Tanaka $K$, Miyano $Y$, Kawaguchi $H$, Takeda $R$, Nishidoi $H$, Kumura O. Results of total gastrectomy for gastric cancer. Am J Surg 1980; 140:636-638

45. Sue-Ling HM, Johnston D, Martin IG, Dixon MF, Landsdown MRJ, McMahon MI, Axon ATR. Gastric cancer: a curable disease in Britain. BMJ 1993;307:591595

46. Takeda J, Koufuji K, Kodama I Tsuji Y, Yokoyama T, Kawabata S, Suematsu T, Kakegawa T. Total gastrectomy for gastric cancer: 12-year data and review of the effect of performing lymphadenectomy. Kurume Med J 1994;41:15-21

47. Moriguchi S, Hayashi $Y$, Nose $Y$ Maehara $Y$, Korenaga D, Sugimachi K. A comparison of the logistic regression and the Cox proportional hazard models in retrospective studies on the prognosis of patients with gastric cancer. J Surg Oncol $1993 ; 52: 9-13$ 
48. Schiessel $R$, Wenzl E, Pratschner T. Results of the surgical therapy of stomach cancer. Wien Klin Wochenschr 1987;99:406-410

49. Hisamichi Shigeru. Screening for Gastric Cancer. World J Surg 1989;13:31-37

50. Takeda J. Koufuji K, Kodama I, Tsuji Y, Maruiwa M, Kawabata S, Soematsu T. Kagegawa T. Retrospective studies of synchronous double early gastric cancer. Kurume Med J 1993;40:53-57

51. Maruyama $K$. The most important prognostic factor for the gastric cancer patient. Scand J Gastroenteral 1987:22:63-68

52. Moureaux J, Bougaran J. Early gastric cancer. A 25-year surgical experience. Ann Surg 1993:217:347-355

53. Pinto E, Roviello F, de Stefano A, Vindigni C. Early gastric cancer: report on 142 patients observed over 13 years. Jpn J Clin Oncoll 1994;24:12-19

54. Spataro V, Genoni M. Maurer C, Müller W. Stomach cancer: 10 years experiences with surgical treatment and possibilities for improving the prognosis. Helv Chir Acta 1993;59:589-595

55. Maehara $Y$, Tomoda M, Tomisaki S, Ohmori M, Baba H, Akazawa K, Suginachi K. Surgical Treatment and Outcome for Node Negative Gastric Cancer. Surgery 1997;121:633-639

56. Jatzko $\mathrm{G}$, Lisborg $\mathrm{Ph}$, Klimpfinger $\mathrm{M}$, Denk $\mathrm{H}$. Extended radical surgery against gastric cancer: low complication and high survival rates. Jpn J Clin Oncol 1992;22:102-106

57. Everett SM, Axon ATR. Early gastric cancer in Europe. Gut 1997;41:142-150

58. Hanazaki K, Sodeyama H, Wakabayashi M, Miyazawa M, Yokoyama S, Sode Y, Kawamura N, Miyazaki T, Ohtsuka M. Surgical treatment of gastric cancer detected by mass screening. Hepato-Gastroenterology 1997:44:1126-1132

59. Nakajima $T$, Nishi $M$, Kajitani T. Improvement in treatment results of gastric cancer with surgery and chemotherapy. Experience of 9700 cases in the Cancer Institute Hospital, Tokyo. Semin Surg Oncol 1991;7:365-372

60. Lawrence W Jr, Menk HR, Steele GD Jr, Winchester DP. The National Cancer Data Base report on gastric cancer. Cancer 1995;75:1734-1744

61. Wanebo HJ, Kennedy Bj, Chmiel J, Steele B, Winchester D, Osleen R. Cancer of the stomach. A patient care study by the American College of Surgeons. Ann Surg $1993 ; 218: 583-592$

62. Tittel A, Schumpelick V. History of Gastric Replacement. Hepato-gastroenterol $1989: 36: 57-62$

63. Catarci M, Proposito D. Guadagni S, Tuscano D, Flati G, Zaraca F, Scaccia M, Scardamaglia $\mathrm{F}$, Carboni $\mathrm{M}$. Histroy of reconstruction following total gastrectomy. Ann ltal Chir 1995;66:319-328

64. Herfarth C, Schlag P, Buh\| K. Surgical Procedures for Gastric Substitution. World J Surg 1987;11:689-698

65. Uras $C$, Yigitbasi $\mathbb{R}$, Erturk $S$, Hamzaoglu I, Sayman $H$. Restrorative caecogastroplasty reconstruction after pylorus-preserving-near total gastrectomy: a preliminary study. Br J Surg 1997;84:406-409 
66. van der Kleij FGH, vecht J, Lamers CBHW. Masclee AAM. Diagnostic value of dumping provocation in patients after gastric surgery. Scand I Gastroenterol $1996 ; 31: 1162-1166$

67. Domjan L, Simon L. Alkaline relux esophagitis in gastroresected patients. Objective detection with a simple isotope method. Scand J Gastroenterol Suppl 1984;92:245249

68. Lantone $G$, Lorusso D, Pezzolla $F$, Lacatena $M$, Guerra V, Giorgio I. Reconstruction of the digestiwe tract after total gastrectomy. A comparison of Roux anastomosis with Nakayama's beta anastomosis. Minerva Chir 1991:46:885-888

69. Parrilla P, Liron R, Martinez de Haro LF, Ortiz A, Molina J, De Andrés B. Castric surgery does not increase the risk of developing Barrett's esophagus. Am J Gastroenterol 1997:92:960-963

70. Goldschwend F. Operations- und Dauerfolge bei bösartiger maligner Geschwulstbildung des Magens. Arch Klin Chir 1908;218-22

71. Kelly WD, Maclean LD, Perry JF, Wangensteen OH. Recent Adwances in Surgery. A study of patients following total and near-total gastrectomy. Surgery $1954 ; 35: 964-982$

72. Wiznitzer T, Rozin R, Menczel J, Aviram A. A comparative sutdy of experimentally produced dumping syndrome after differen types of gastric surgery. Am J Gastroenterol 1966:45:91-98.

73. Adams JF. The climical and metabolic consequences of total gastrectomy. I. Morbidity, weight, and nutrition. Scand J Gastroenterol 1967;2:137-149

74. Bradley EL, Isaacs $J$, Hersch T, Davidson ED, Milikan W. Nutritional consequences of total gastrectomy. Ann Surg 1975;182:415-429

75. Olbe L, Lundell $L$. Intestinal Function after Total Gastrectomy and Possible Consequences of Gastric Replacement. World J Surg 1987;11:713-719

76. Schlag P, Buhl $\mathbb{K}$, Wysocki ST, Schwartz $R$, Herfarth $C H$. Nutritional Consequences of Total Gastrectomy: Esophagojejeunostomy ws. Jejunum Pouch as Reconstructive Procedures. Nutrition 1988;4:235-238

77. Miholic J. Meyer HD, Konzerke J, Balks J, Aebert $H$, Jăne J, Weimann $A$, Pichlmayr R. Emptying of the Gastric Substitute After Total Gastrectomy: Jejunal Interposition versus Roux-en-Y. Ann Surg 1989;210:165-172

78. Miholic J, Meyer HJ, Müller MJ. Weimann A, Pichlmayr R. Nutritional consequences of total gastrectomy. The relationship between mode of reconstruction, postprandial symptoms, and body composition. Surgery $1990 ; 108: 488-494$

79. Bozzeti F, Ravera E, Cozzaglio L, Dossena G, Agradi E, Bonfanti G, Koukouras $D$, Gemari L. Comparison of nutritional status after total or subtotal gastrectomy. Nutrition 1990:6:371-375

80. Delbrück $H$, Severin M, Jansen G. Postgastrectomy findings in the after care of 227 patients with stomach carcinoma. Z Gastroenterol 1991;29:222-226 


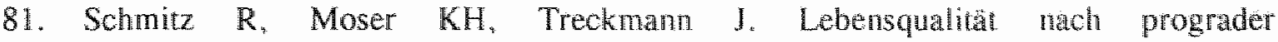
Jejunuminterposition mit und ohne Pouch. Eine prospektive Studie bei Magencarcinompatienten zur Frage des Reservoirs als Rekonstruktionsprinzip nach totaler Gastrektomie. Chirurg 1994:65:326-332

82. Delbrück $H$, Kruck $P$, Braun $G$. Beschwerdebild nach partieller und totaler Gastrektomie: Zusammenhange mit der Pankreasfunktion und Mơglichkeit der therapeutischen BeeinfluBung. In: Delbrück $H$, Layer P. Kaiser D, Bosseckert $H$, Ditschuneit $H$ eds. Die Gesichter der Pankreasinsuffizienz. Einhorn Verlag Reinbeck, 1994:9-40

83. Anderson ID, Maclntyre IM. Symptomatic outcome following resection of gastric cancer. Surg Oncol 1995;4:35-40

84. Nakane $Y$, Okumura S, Akehira K, Okamura S, Boku T, Okusa T, Tanaka K, Hioki K. Jejunal pouch reconstruction after total gastrectomy for cancer. A randomized controlled trial. Ann Surg 1995;222:27-35

85. Basso N, Materia A, Gizzonio D, Marcelli M, De Marco M. Tamburrano G. Nutritional effects of total gasitrectomy. A prospective randomized study of Rouxen-Y vs Longmire-Mouchet reconstruction. Ital J Surg Sci 1985;15:335-340

86. Cristallo M, Braga M, Agape D, Primignani M, Zuliani W, Vecchi M, Murone M, Sironi M, Di Carlo $V$, De Franchis R. Nutritional status, function of the small intestine and jejunal morphology after total gastrectomy for carcinoma of the stomach. Surg Gyn Obst 1986;163:225-230

87. Troidl H, Kusche J, Vestweber JH, Eypasch E, Maul U. Pouch versus oesophagojejunuostomy after total gastrectomy: A randomized clinical trial World J Surg 1987;11:699-712

88. Sategna Guidetti C, Bianco L, Malnutrition and malabsorption after total gastrectomy. A pathophysiologic approach. J Clin Gastroenterol 1989;11:518-524

89. Cruciti F, Pacelli F, Doglietto GB, Bellantone $R$, Perri V, Bossola M, Tommasini O, Miggiano G. RouX-en-Y Esophagojejunostomy in Reconstruction of the Alimentary Tract after Total Gastrectomy for Carcinoma of the Stomach. Nutrition $1990 ; 6: 261-263$

90. Curran FT, Hill GL. Failure of mutritional recovery after total gastrectomy. Br J Surg 1990;77:1015-1017

91. Miholic J, Meyer HJ, Balks I, Kotzerke I. Einfluß der Rekonstruktionsmethode auf den Ernährungszustand nach Gastrektomie. Vergleich von Roux-en-Y Ösophagojejunostomie und Jejunuminterposition. Chirurg 1991:62:300-305

92. Köhler H, Schafmayer A, Peiper HJ. Die sekundäre exokrine Pankreasinsuffizienz nach Magenresektion. In: Pankreas, Diagnostik, Therapie. Kozuschek W, Paguet KJ. eds. Freiburg, S. Karger GmbH, 1992:547-554

93. Tsuburaya A, Noguchi $Y$, Yoshikawa T, Nomura K, Fukuzawa K, Makino T. Long-term effect of radical gastrectomy on nutrition and immunity. Surg. Today $1993 ; 23: 320-324$

94. Fuchs KH, Thiede A, Engemann R, Deltz E, Stremme O, Hamelmann H. Reconstruction of the food passage after total gastrectomy: randomized trial. World J Surg 1995; 19:698-705 
95. Liedman B, Andersson H, Berglund B, Bosaeus I, Hugosson I, Olbe L, Lundell L. Food intake after gastrectomy for gastric carcinoma: the role of a gastric reservoir. Br J Surg 1996;83:1138-1143

96. Bozzetti F, Bonfanti G, Castellani R, Maffioli L, Rubino A, Diazzi G, Cozzaglio L, Gennari $L$. Comparing reconstruction with Roux-en- $Y$ to a pouch following total gastrectomy, J Am Coll Surg 1996;183:243-248

97. Schwarz A, Büchler $M$, Usinger $K$, Rieger $H$, Glasbrenner $B$, Friess $H$, Kunz $R$, Beger HG. Importance of the duodenal passage and pouch volume after total gastrectomy and reconstruction with the Ulm pouch: prospective randomized clinical study. World J Surg 1996;20:60-67

98. Liedman B, Andersson H, Bosaeus MD, Hugosson BSC, Lundell L. Changes in Body Composition after Gastrectomy: Results of a Controlled Prospective Clinical Trial. World J Surg 1997:21:416-421

99. Bisballe S, Buus S, Lund B, Hessov I. Food Intake And Nutritional Status After Gastrectomy, Human Nutrition: Clinical Nutrition 1986;40:301-308

100. Walther B, Clementson C, Vallgren S, thse I, Ảkesson B. Fat malabsorption in patients before and after total gastrectomy, studied by the triolein breath test. Scand J Gastroenterol 1989:24:309-314

101. Wróblewski A. Eine chemische Notiz zur Schlatter'schen totalen Magenexstirpation. Zentrabl f Physiol 1898;11:665-668

102. Hofmann A. Stoffwechseluntersuchungen nach totaler Magenresection. München Med Wchnschr 1898;45:560-564

103. Schwartz MK, Bodansky O, Randal L. Metabolism in surgical patients. II. Fat and mineral metabolism in totally gastrectomized patients. Am J Clin Nutr 1956;4:51-60

104. Lawrence W Jr. Reconstruction After Total Gastrectomy: What Is The Preferred Technique? J Surg Onc 1996;63:215-220

105. Breitenbach G. Stoffwechselwersuch nach totaler Maganresektion. München Med Wchnschr 1929;46:1920-1921

106. Farris JM, Ransom HK, Coller FA. Total Gastrectomy: Effects upon Nutrition and Hematopoisis. Surgery 1943:13:823-833

107. Brintnall ES, Daum K, Hickey RC, Tidrick RT, Wickstrom AP. Total Gastrectomy: An Evaluation. J Int Coll Surg 1956;24:409-420

108. Hays RP, Clark DA. Nutrition in Patients with Total Gastrectomy and a Jejunal Food Pouch. Ann Surg 1960; 152:864-870

109. Fischermann K, Harly S, Worning $H$, Zacho A. Pancreatic function and the absorption of fat, iron, vitamin $\mathrm{B}_{12}$, and calcium after total gastrectomy for gastric cancer. Gut 1967;8:260-266

110. Bradley EL. Isaacs JT, Mazo JD, Hersh T, Chey WY. Pathophysiology and significance of malabsorption after Roux-en-Y reconstruction. Surgery 1977;81:684691

111. Gullo L, Costa L, Ventrucci M, Mattioli S, Vitti G, Labò G. Exocrine Pancreas Function after Total Gastrectomy. Scand J Gastroent 1979;14:401-407

112. Hobbs JR. Iron deficiency after partial gastrectomy. Gut $1961 ; 2: 141-149$

113. Hillman HS. Postgastrectomy malnutrition. Gut 1968;9:576-584 
114. Adlams JF. The clinical and metabolic consequences of toral gastrectomy. II. Anaemia. Metabolism of Iron, Vitamin $B_{12}$ and Folic Acid. Scand $J$ Gastroent $1968 ; 3: 145-151$

115. Tovey FI, Clark CG. Anaemia after partial gastrectomy: a neglected curable condition. The Lancet $1980: 956$-957

116. Walter $\mathbb{F}$. Adler $K$, Baumann J, Sorger $D$, Winkler $E$. Vitamin $B_{12}$ levels in the serum in gastrectomized patients. Zentralbl Chir 1984;109:803-808

117. Amaral JF, Thompson WR, Caldwell MD, Martin HF, Randall HT. Prospective hematologic evaluation of gastric exclusion surgery for morbid obesity. Ann Surg $1985 ; 201: 186-193$

118. Tovey FI, Godfrey JE, Lewin MR. A gastrectomy population: 25-30 years on. Postgrad Med J 1990;66:450-456

119. Harju $\mathbb{E}$. Metabolic problems after gastric surgery. Int Surg 1990;75:27-35

120. Schölmerich J, Holstege A. Micronutrients: Deficiency and treatment after Total Gastrectomy. Nutrition 1988;4:317-319

121. Magnusson B, Faxen A, Cederblad A, Rosander L, Kewenter J, Hallber L. The effect of parietal cell vagotomy and selective vagotomy with pyloroplasty on iron absorption. A prospective randomized study. Scand J Gastroenterol 1979;14:177. 182

122. Harju E, Larmi TKI. The Effects of Gastric Surgery on Serum ferritin Concentrations. Int Surg 1984;69:51-54

123. Schröder H, Winnefell $K$, Splinter $K$. Untersuchungen zum Verhalten des Serumeisens und der totalen Eisenbindungskapazität nach Gastrektomie. Dt Z Verdau u Stoffwechselkr 1984;44:1 18-120

124. Gianmella RA, Toskes PP. Gastrointestinal bleeding and iron absorption in the experimental blind loop sydrome. Am J Clin Nutr 1976;29:754-757

125. Husebye E. Gastrointestinal motility disorders and bacterial overgrowth. J Internal Medicine 1995;237:419-427.

126. King CE, Toskes PP. Small intestinal bacterial overgrowth. Gastroenterology $1979 ; 76: 1035-1055$

127. Sherman PM. Bacterial Overgrowth. In: Yamada T ed, Textbook of Gastroenterology, 1st edition, Philadelphia: Lippincott Company, 1991:1673-80

128. Hoffbrand AV, Tabaqchali S, Mollin DL. High serum-folate levels in intestinal blind loop syndrome. The Lancet 1966; 1:1339-1342

129. Maier GW, Kreiss ME, Zittel TT, Becker HD. Calcium Regulation and Bone Mass Loss After Total Gastrectomy in Pigs. Ann Surg 1997;225:181-192

130. Rumenapf G, Schwille PO, Erben RG, Schreiber M, Fires W, Schmiedl A, Hohenberger W. Osteopenia following total gastrectomy in the ral: State of mineral metabolism and bone histomorphometry. Eur Surg Res 1997;29:209-221

131. Bisballe S, Eriksen EF, Melsen F, Mosekilde L, Sørensen OH, Hessov I. Osteopenia and osteomalacia after gastrectomy: interrelations beween biochemical markers of bone remodelling, vitamin $D$ metabolites, and bone histomorphometry. Gut 1991:32:1303-1307 
132. Krogsgaard MR, Frolich A, Lund B, Lund B. Long-term Changes in Bone Mass after Partial Gastrectomy in a Well-Defined Population and Its Relation to Tobacco and Alcohol Consumption. World J Surg 1995;19:867-871

133. v d Wielen RPJ, Löwik MRH, van d Berg $H$, de Groot LCPGM, Haller J, Moreiras O, van Staveren WA. Serum vitamin D concentrations among elderly people in Europe. The Lancet 1995;346:207-210

134. Kirchner R, Schölmerich J, Schäfer U, Holstege A, Häring RU, Reinbold WD. Inwieweit sind Mangelzustände gastrektomierter Patienten der Gastrektomie anzulasten? In: Häring $R$ et al, eds. Chirurgisches Forum $1990 \mathrm{f}$. experim. $u$. klinische Forschung. Springer Verlag, 1990:223-226

135. Stael-von-Holstein $C$, Ibrahimbegovic $E$, Walther $B$, Akesson B. Nutrient intake and biochemical markers of nutritional status during long-term follow-up after total and parital gastrectomy. Eur J Clin Nutr 1992;46:265-272

136. Roberts KE, Randall HT, Bane HN, Medwid A, Schwartz MK. Studies of the physiology of dumping syndrome. NY State J Med 1955;55:2897-2902

137. Braga M, Zulian W, Luciano F, Cristallo M, Carlo VD. Nutritional Follow-up after total Gastrectomy. Nutrition 1990;6:177-178

138. Leth RD, Abrahamsson H, Kilander A, Lundell LR. Malabsorption of fat after partial gastric resection. A study of pathophysiological mechanisms. Eur I Surg $1991 ; 157: 205-208$

139. Carriere F. Barrowman JA, Verger R, Laugier R. Secretion and Contribution to Lipolysis of Gastric and Pancreatic Lipases During a test Meal in Humans. Gastroenterology 1993; 105:876-888

140. Annis D, Hallenbeck GA. The effects of partial gastrectomy on canine external pancreatic secretion. Surgery 1952;31:517-527

141. Büchler M, Malfertheiner P, Glasbrenner B, Firiess H, Beger HG. Secondary Pancreatic Insufficiency Following Partial and Total Gastrectomy. Nutrition $1988: 4: 314-316$

142. Friess H, Böhm J, Malfertheiner P. Glasbrenner B, Müller M, Hofbauer B, Riepl RL. Büchler MW. Exokrine Pankreasinsuffizienz nach Gastrektomie: Eine primáre Funktionsstörung. Chirurgische Gastoenterologie 1994;10:324-330

143. Friess H. Bölm J. Müller MW, Glasbrenner B, Riepl RL, Malferthemer P, Büchler MW. Maldigestion after total gastreciomy is assoctated with pancreatic insufficiency. Am J Gastroenterol 1996;91:341-347

144. Fuchs $M$, Kohler H, Scharmayer A. Einfluss verschiedener Resektionsverfahren am Magen auf die Freisetzung von Cholecystokinin, Neurotensin und die Pankreasfunktion. Zentrib| Chir 1995;120:472-477

145. Mackay C. Postgastrectomy steatorrhea. Am J Surg 1970;120:324-328

146. Armbrecht U, Lundell L, Lindstedt G, Stockbrügger RW. Causes of malabsorption atter total gastrectomy with Roux-en-Y reconstruction. Acta Chir Scand $1988 ; 154: 37-41$

147. Bond JH, Levitt MD. Use of breath hydrogen $\left(\mathrm{H}_{2}\right)$ to quantitate small bowel transit time following partial gastrectomy. J Lab Clin Med 1977;90:30-36 
148. Lundh $\mathrm{G}$. Intestinal digestion and absorption after gastrectomy. Acta Chir Scand $1958 ; 231: 1-83$

149. MacGregor I, Parent J, Meyer JH. Gastric emptying of liquid meals and pancreatic and billiary secretion after subtotal gastrectomy or truncal vagotomy and pyloroplasty in man. Gastroenterology 1977;72:195-205

150. Tabaqchali $S$. The Pathophysiological Role of Small Intestinal Bacterial Flora. Scand J Gastroenterol 1970;6:139-163

151. Toskes PP, Giannella RA, Jerwis HR, Rout WR, Takeuchi A. Small intestinal mucosal injury in the experimental blind loop sundrome: light and electronmicroscopic and histochemical studies. Gastroenterology 1975:68:1193-1203

152. Toskes PP, King CE, Spivey $I C$, Lorenz E. Xylose catabolism in the experimental rat blind loop syndrome: studies including use of a newly developed $d-{ }^{14} \mathrm{C}$ xylose. breath test. Gastroenterology 1978;74:69:-697

153. Harju E. Dietary habits and eating related symptoms in out-patients following total gastrectomy and Roux-en-Y reconstruction for carcinoma of the stomach. Anticancer Res 1985;5:277-279

154. Raab M, Stützer H, Kotthoff G. Ernnährungsanalyse nach vollständiger Entfernung des Magens wegen eines malignen Tumors. Akt Ernähr 1988;13:10-14

155. Fredrix EW, Soeters PB, Wouter EF, Deerenberg IM, von Meyenfeldt MF, Saris WH. Effect of different tumor types on resting energy expenditure. Cancer Res $1991: 51: 6138-6141$

156. Everson TC. Nutrition following total gastrectomy, with particular reference to fat and protein assimilation. Internat. Abst Surg 1952;95:209

157. Wechsler, JG. Ernährungsverhalten und Diät nach Gastrektomie. In: Der gastrektomierte Patient. Armbrecht U, Stockbrügger RW eds. Freiburg, S. Karger GmbH 1992:79-87

158. Cosnes J, Lamy P, Beaugerie L, Le Quintrec M, Gendre JP, Le Quintrec Y. Adaptive hyperphagia in patients with postsurgical malabsorption. Gastroenterology 1990:99:1814-1819

159. Heptner G, Domschke S, Domschke W. Exocrine Pancreatic Function After Gastrectomy - Specificity of Indirect Tests. Gastroenterology 1989:97:147-153

160. Lembcke B, Konle O, Duan LP. Caspary WF. Lack of accuracy of plasma $\alpha$-amino nitrogen profiles as an indicator of exocrine pancreatic function both after continuous and bolus stimulation of the pancreas with sectetin and choecystokinin pancreozymin. Z Gastroenterol 1994;32:679-683

161. Maringhini A, Nelson DK, Jones JD, DiMagno EP. Is the plasma amino acid consumption test an accurate test of exocrine pancreatic insufficiency? Gastroenterology 1994; 106:488-493

162. DiMagno EP, Go VLW, Summerskill WHJ. Relations between pancreatic enzyme outputs and malabsorption in severe pancreatic insufficiency. N Eng I Med $1973 ; 288: 813-815$

163. Hamosh M, Burns WA. Lipolytic activity of human lingual glands (Ebner). Lab Invest 1977;37:603-608 
164. Büchler M, Malfertheiner P, Glasbrenner B, Beger HG. Rat exocrine pancreas function following total gastrectomy. Int J Pancreatol 1986;1:389-398

165. Glasbrenner B, Malfertheiner $P$, Buchler $M$, Brandle $F$, Friess $H$, Ditschuneit $H$. Long-term effect of growth promoting conditions on the exocrine pancreas of rats. Int J Pancreatol 1989;5:55-67

166. Büchler $M$, Malfertheiner $P$, Friess $H$, Nustede $R$, Feurle GE, Geger $H G$. Cholecystokinin influences pancreatic trophism following total gastrectomy in rats. Int J Pancreatol 1989:4:261-271

167. Búchler M, Malfertheiner $P$, Glasbrenner B, Friess H, Beger HG. Secondary Pancreatic Insufficiency Following Partial and Total Gastrectomy. Nutrition $1988 ; 4: 314-316$

168. Friess $H$, Böhm $J$, Ebert $M$, Büchler $M$. Enzyme treatment after gastrointestinal surgery. Digestion 1993;54:48-53

169. Layer P, Holst JJ, Grandt D, Goebell H. lleal release of gluciagon-like peptide-1 (GLP-1). Association with inhibition of gastirc acid secetion in Humans. Dig Dis Sci $1995 ; 40: 1074 ; 082$

170. Layer P, Schlesinger $T$, Gröger G, Goebell H. Modulation of Human Periodic Interdigestive Gastrointestinal Motor and Pancreatic Function by the lleum. Pancreas 1993;8:426-432

171. Worning $H$. The effect of enzyme substitution in patients with pancreatic insufficiency. Scand I Gastroenterol 1980;15:529-533

172. Tillander $H$, Tveit E. Beeinflussung des Dumping -Syndroms mit Pankreon. Münch Med Wschr 1978;120:1717-1718

173. Armbrecht U, Lundell L, Stockbrügger RW. The benefit of pancreatic enzyme substitution after total gastrectomy. Aliment Pharmacol Therap 1988;2:493-500

174. Lankisch PG. Enzyme Treatment of Exocrine Pancreatic Insufficiency in Chronic Pancreatitis. Digestion 1993;54:21-29

175. Heil TH, Etzrodt H, Mattes P, Peros G, Herfarth CH. Gastrectomy with and without duodenal transit: release of glucagon, insulin and somatostatin. Scand $J$ Gastroenterol $1981 ; 16: 83-87$

176. Sichwarz A, Friess H, Usinger K, Büchler MW, Beger HG. The influence of the type of reconsuruction after total gastrectomy on the release of GIP and iss importance for the release of insulin. Langenbecks Arch Chir 1996;6:81-84

177. Miholic J, Orskov C, Holst JJ, Kotzerke J, Meyer HJ. Emptying of the gastric substitute, glucagon-like peptide-1 (GLP-1), and reactive hypoglycemia after total gastrectomy. Dig Dis Sci 1991;36:1361-1370

178. Faß $\mathrm{J}$, Bares $\mathrm{R}$, Hermsdorf $\mathrm{V}$, Schumpelick $\mathrm{V}$. Intestinal motility after jejunum interposition and Roux-Y construction - an animal experiment study. Langenbecks Arch Chir 1993:378:239-248

179. FaB J, Bares R, Staude M, Schumpelick V. Type of stomach replacement and intestinal motility after total gastrectomy. Leber Magen Darm 1993;194:197-203

180. Bassorti G, Chiarienalli ML, Germani U, Chiarioni G, Morelli A. Effects of Some Abdominal Surgical Operations on Small Bowel Motility in Humans: Our Experience, J Clin Gastroenterol 1995:21:211-216 
181. van der Mijle HC, Kleibeuker JH, Limburg AI, Bleichrodt RP, Beekhuis H, wan Schilfgaarde $R$. Manometric and scintrigraphic studies of the relation between motillity disturbances in the Roux limb and the Roux-en-Y syndrome. Am I Surg $1993 ; 166: 11-17$

182. Miedema BW, Kelly KA, Camilleri M, Hanson RB, Zinsmeister AR, O'Connor MK, Brown ML. Human gasuric and jejunal transit and motility after Roux gastrojejunostomy. Gastroenterology $1992 ; 103: 1133-43$

183. Junginger TH, Walgenbach S. Postgastrectomy Reconstruction By Esophagojejunostomy Roux-en-Y. Nutrition 1988:4:239-242

184. Michielsen D, Van Hee R, Hendrickx L, Creve U, Peeters R. Functional results after total gastrectomy with enteric pouch reconstruction. A review of 34 cases. Acta Chir Belg 1996;96:155-157

185. Roder JD, Herschbach P, Henrich G, Nagel M, Botther $K$, Siewert IR. Lebensqualität nach totaler Gastrektomie wegen Magenkarzinoms. Ösophagojejunoplicatio mit Pouch versus Ösophagojejunostomie ohne Pouch. Disch Med Wochenschr 1992;117:241-247

186. Roder JD, Stein HJ, Eckel F, Herschbach P. Henrich G, Bottcher K, Busch R, Siewert JR. Vergleich der Lebensqualität nach subtotaler und totaler Gastrektomie beim Magenkarzinom. Disch Med Wochenschr 1996; 121:543-549

187. Buhl $\mathrm{K}$, Lehnert $T$, Schlag P, Herfarth $\mathrm{C}$. Reconstruction after gastrectomy and quality of life. World J Surgery 1995;19:558-564

188. Thiede A. Magenersatzoperation und Lebensqualität. In: Fuchs KH, Hamelmann H eds. Gastrointestinale Funktionsdiagnostik in der Chirurgie. Berlin: Blackwell Wissenschaft, 1991:222-228

189. Broll R, Muller G, Burk C, Stefanovich P, Bruch HP. Disturbed esophageal motility after total gastrectomy. Acta Chir Belg 1993;93:78-82

190. McAleese P, Calvert H, Ferguson WR, Laird J. Evaluation of "gastric" emptying time in the $\mathrm{J}$ pouch compared with a standard esophagojejunal anastomosis. World $J$ Surg. 1993:17:595-599

191. Behrns KE, Sarr MG. Diagnosis and management of gastric emptying disorders. Adv Surg 1994;27:233-255

192. Stier A, Hölscher AH, Schwaiger M, Siewert JR. Jejunumpouch nach totaler Gastrektomie-Klinische und szintigraphische Untersuchungen zu Funktion und Befindlichkeit. Zentralbl Chir 1994;119:838-844

193. Beese G, Fuchs KH, Thiede A. Experimental studies of the value of the pouch after gastrectomy. Zentralbl Chir 1994;119:904-910

194. Tanaka T, Fujiwara Y, Nakagawa K, Kusunoki M, Uiunomiya J. Reflux Esophagitis after Total Gastrectomy with Jejunal Poucl Reconstruction: Comparison of Long and Short Pouches. Am J Gastroenterol 1997;92:821-824

195. de Almeida AC, dos-Santos NH, Aldeia FJ. Long-term clinical and endoscopic assessment after total gastrectomy for cancer. Surg Endosc 1993;7:518 -523

196. Nakane $\mathrm{Y}$, Akehira K, Okumura S, Okamura S. Osawa T, Okusa T, Hioki K. Emptying of the jejunal pouch as a gastric substitute after total gastrectomy for cancer. Hepato Gastroenterology 1997;44:901-906 
197. Li Destri $G$. Trombatore $G$, La Greca $G$, Rinzivillo $C$, Rodolico $M$, Desiderio $C$, Orsina N, Di Cataldo A. Puleo S. Total gastrectomy: nutritional status after three different reconstruction techniques. An experimental study. I Surg Oncol $1992 ; 49: 98-102$

198. Corbett CL, Thiomas $S$, Read NW, Hobson $\mathbb{N}$, Bergman I, Holdsworth CD. Electrochemical detector for breath hydrogen determination: measurement of small bowel transit time in nomal subjects and patients with the irritable bowel syndrome. Gut 1981;22:836-840

199. Boud JH Jr, Leviti MD, Prentiss $\mathbb{R}$. Investigation of small bowel transit time in man utilizing pulmonary hydrogen $\left(\mathrm{H}_{2}\right)$ measurements. J Lab Clin Med 1975;85:546-555

200. Korth H, Muller I. Erkenbrecht JF, Wienbeck M. Breath hydrogen as a test for gastrointestinal transit. Hepatogastroenterology 1984;31:282-284

201. Armbrecht U, Jensen J, Eden S, Stockbrügger RW. Assessment of Oro-coecal Transit Time by Means of a Hydrogen $\left(\mathrm{H}_{2}\right)$ Breath Test As Compared with a Radiologic Control Method. Scand J Gastroenterol 1986:21:669-677

202. von der Ohe MR, Camilleri M. Measurement of small bowel and colonic transit: indications and methods. Mayo Clin Proc 1992;67:1169-1179

203. Argenyi ES, Soffer EE, Madsen MT, Berbaum KS, Walkner WO. Scintigraphic evaluation of small bowel transit in healthy subjects: inter and intrasubject variability. Am J Gastroenterol 1995;90:938-942

204. Maurer AH, Krevsky B. Whole-gut transit scintigraphy in the evaluation of smallbowel and colon transit disorders. Semin Nucl Med 1995;25:326-338

205. Malagelada JR, Robertson JS, Brown ML, Remington M, Duenes JA, Thomforde GM. Carryer PW. Intestinal Transit of Solid and Liquid Components of a Meal in Health. Gastroenterology 1.984;87:1255-1263

206. Read NW, Al-Janabi MN, Holgate AM, Barber DC, Edwards CA. Simultaneous measurement of gastric emptying, small bowel residence and colonic filling of a solid meal by the use of the gamma camera. Gut 1986;27:300-308

207. Camilleri M, Colemont Ld, Philips SSF, Brown ML, Thomforde GM, Chapman N, Zinsmeister A.R. Human gastric emplying and colonic filling of solids characterized by a new method. Am J Physiol 1989*257:284-290

208. Kerlin P, Byrnes O, Wong L. Radiolabelled unprocessed bran: Validation of a practical labelling technique and evaluation of gastrointestimal profiles in health. J Gastroenterol Hepatol 1989;4:119-126

209. Camilleri M. Zinsmeister AR, Greydanus MP, Brown ML, Proano M. Towards a less costly but accurate test of gastric emptying and small bowel transit. Dig Dis Sci $1991 ; 36: 609-615$

210. Miller MA, Parkman HP, Brown KL, Donahue DJ, Knight LC, Urbain I-L, Maurer AH. Fisher RS. The lactulose breath test is not a physiologic standard for orocecal transit: Lactulose delays gastric emptying and accelerates small bowel transit. Gastroenterology 1995;108:A650

211. Pilloto A. Franceschi M. Del Favero G, Fabrello R, Di Mario F, Valerio G. The effect of aging on oro-coecal transit time in normal subjects and patients with gallstone disease. Aging Clin Exp Res 1995;7:234-237 
212. Kupfer RM, Heppel M, Haggith JW, Bateman DN. Gastric emptying and small bowel transit rate in the elderly. J Am Geriatr Soc 1985;33:340-343

213. Wegener M, Borsch G, Schaffstein J, Luth I, Rickels R, Ricken D. Effect of aging on the gastrointestinal transit of a lactulose supplemented mixed solid-liquid meal in humans. Digestion 1988;39:40-46

214. Wald A, Van Thiel DH, Hoechstetter L, Gavaler IS, Egler KM. Verm R, Scott L, Lester R. Gastrointestinal transit: The effect of the menstrual cycle. Gastroenterology 1981;80:1497-1500

215. Read NW, Cammack I, Edwards C, Holgate AM, Cann PA, Brown C. Is the transit time of a meal through the small intestine related to the rate at which it leaves the stomach? Gut $1982 ; 23: 824-828$

216. Armbrecht U, Dotevall G, Stockbrügger RW. The effect of gastric secretion on orocoecal transit time measured with the hydrogen (H2) breath test. $Z$ Gastroenterologie 1987;25:145-150

217. Mizumoto A, Sarr MG, DiMagno EP. Do pancreatic enzymes regulate oroileal transit in canine pancreatic insufficiency? Gastroenterology 1995; 108:A377

218. Richardson A, Delbridge AT, Brown NJ, Rumsey RD, Read NW. Short chain fatty acids in the terminal ileum accelerate stomach to caecum transit time in the rat. Gut $1991 ; 32: 266-269$

219. Ledeboer M, Masclee AA, Jansen JB, Lamers CB. Effect of equimolar amounts of long-chain triglycerides and medium-chain triglycerides on small-bowel transit time in humans. Jour Parenter Enteral Nutr 1995;19:5-8

220. Dreznik Z, Brocksmith D, Meininger TA, Soper NJ. Inhibitory effect of ileal oleate on postprandial motility of the upper gut. Am J Physiol 1990;26:458-463

221. Read NW, McFarlane A, Kinsman RI, Bates TE, Blackhall NW, Farrar GBJ, Hall JC, Moss G, Morris AP, O'Neill B, Welch I, Lee Y, Bloom SR. Effect of Infusion of Nutrient Solutions Into the Ileum on Gastointestinal Transit and Plasma Levels of Neurotensin and Enteroglucagon. Gastroenterology 1984:86:274-280

222. Holgate AM, Read NW. Effect of Ileal Infusion of Intralipid on Gastrointestinal Transit, Ileal Flow Rate, and Carbohydrate Absorption in Humans After Ingestion of a Liquid Meal. Gastroenterology 1985;88:1005-1011

223. Spiller RC, Trotman IF, Higgins BE, Ghatei MA, Grimble GK, Lee YC, Bloom SR. Misiewicz JJ, Silk DBA. The ileal brake - inhibition of jejunal motility after ileal fat perfusion in man. Gut 1984:25:365-374

224. Steed KP, Bohemen EK, Lamont GM, Evans DF", Wilson CG, Spiller RC. Proximal colonic responses and gastrointestinal transit after high and low fat meals. Dig Dis Sci $1993 ; 38: 1793-1800$

225. Cunningham $\mathbb{K M}$, Daly J, Horowitz M. Read NW. Gastrointestinal adaptation to diets of differing fat composition in human volunteers. Gut 1991:32:483-486

226. Brown NJ, Rumsey RD, Read NW. Gastrointestinal adaptation to enlanced small intestinal lipid exposure. Gut 1994;35:1409-1412

227. Thomas H, Heimbucher J, Fuchs KH, Freys SM, DeMeester TR, Peters JH, Bremner CG, Thiede A: The mode of RouX-en-Y reconstruction affects motility in the efferent limb. Arch Surg 1996;131:63-66 
228. Gustavsson $S$. Transport of small bowel contents after interposition of an antiperistaltic jejunal segment in the rat. Eur Surg Res 1979;11:381-391

229. Pezzola F, Lantone G, Guerra V. Misciagna G, Prete F, Giorgio I, Lorusso D: Influence of the method of digestive tract reconstruction on galistone development after total gastrectomy for gastric cancer. Am I Surg 1993;166:6-17

230 Takahashi T, Yamamura T, Yokohama E, Kantoh M, Kusunoki M, Ishikawa Y, Utsunomiya J. Impaired contractile motility of the gallbladder after gastrectomy. Am J Gastroenterol 1986;81:672-677

231. Pellegrini CA, Deveney CW, Patti MG, Lewin M, Way LW. Intestinal transit of food after total gastrectomy and Roux-Y esophagojejunostomy. Am J Surg 1986; 151:117-125

232. Sellin $\mathrm{JH}_{\text {, Hart }} \mathrm{R}$. Glucose malabsorption associated with rapid intestinal transit. Am J Gastroenterol 1992:87:584-589

233. Morsiani E, Tassinati E, Rescazzi R, Benea G. Rapid intestinal transit and postgastrectomy malnutrition. An experimental study in growing rats. Ital J Surg Sci $1985 ; 139-144$

234. Toskes PP, Donaldson RM. Enteric Bacterial Flora and Bacterial Overgroweln Syndrom. In: Sleisinger MH, Fordtran IS eds. Gastrointestinal disease: pathophysiology, diagnosis, management. Philadelphia: WB Saunders 1993:11061118

235. Ellen Li. Bacterial Overgrowth. In: Yamada T ed. Textbook of Gastroenterology, 2nd edition, Philadelphia: Lippincott Company, 1995:1673-80

236. Corazza GR, Menozzi MG, Stocchi A, Rasciti L, Varia D, Lecchini R, Avanzini P, Chezzi $C$, Gasbaririni $G$. The diagnosis of small bowel bacterial overgrowth. Reliability of jejunal culture and inadequecy of breath hydrogen testing. Gastroenterology 1990;98:302-309

237. Armbrecht U, Eden S, Seeberg S, Stockbrügger RW. The Value of the Hydrogen $\left(\mathrm{H}_{2}\right)$ Breath Test for the Diagnosis of Bacterial Overgrowth in Gastric Achlohydria. Hepato-gastroenterol 1987;34:219-222

238. Konishi T, Takahashi $M$, Ohta $S$, Basic studies on 5-(7-hydroxy-3-Ophosphonocholy) aminosalicylic acid for the evaluation of microbial overgrowth. Biol Pharm Bull 1997:20:370-375

239. Goldstein F, Wiris CW, Kowlessar OD. Diabetic diarrhea and steatorrhea: microbiologiy and clinical observations. Ann Intern Med 1970;72:215-218

240. Vantrappen $G$, Janssens $J$, Coremans $G$, Jian R. Gastrointestinal motility disorders. Dig Dis Sci 1986;31:5-25

241. Husebye E. Gastrointestinal motility disorders and bacterial overgrowth. J Int Med 1995;237:419-427

242. Atwater IS, Butt HR, Priestly JT. Gastrojejunocolic fistulae with special reference to associated nutritional deficiencies and certain surgical aspects. Ann Surg 1943:117:414-419

243. Griffin WO Jr, Richardson JD. Medley ES. Prevention of small bowel contamination by ileocecal valve. South Med J 1971;64:1056-1058 
244. Drasar BS, Shiner M. McLeod GM. Studies on the intestinal flond. 1. The bacterial flora of the gastrointestinal tract in healthy and achlorbydric persons. Gastroenterology 1969;56:71-79

245. Stockbrügger RW, Cotton PB, Eugenides N. Bartholomew BA. Hill MI. Walters CL. Intragastric nitrites, nitrosamines, and bacterial overgrowh during cimetidine treatment. Gut 1982;23:1048-54

246. Roberts SH, Janes $\mathrm{O}$, Jarvis EH. Bacterial contamination of the small intestine is an important cause of occult malabsorption in the elderly. The Lancet 1977:2:1193. 1195

247. Saltzman JR, Kowdley KV, Pedrosa MC, Sepe T, Golner B, Perrone G, Russel RM. Bacterial overgrowth without clinical malabsorption in alderly hypochlorhydric subjects. Gastroenterology 1994; 107:1214-1215

248. Stockbrügger RW, Armbrecht U, Rode JW, Teall AJ, Oberholzer VG, Croker IR, Cotton PB. The Bacterial Overgrowth Syndrome is Uncommon in Pernicious Anaemia: Results of a Follow-up Study. Microbial Ecology in Health and Disease $1990 ; 3: 209-215$

249. Dawson AM, Isselbacher KJ, Bell VM. Studies on lipid metabolism in the small intestine with observations on the role of bile salts. J Clin Invest 1960:39:730-40

250. Haboubi NY. Montgomery RD. Snall-bowel bacterial overgrowth in elderly people: clinical significatice and response to treatment. Age-Ageing 1992;21:13-19

251. Khin-Maung U, Bolin TD, Ducombe VM, Myo Khin, Nyunt-Nyunt Wai, Pereira SP, Linklater JM. Epidemiology of small bowel bacterial overgrowth and rice carbohydrate malabsorption in Burmese (Myanmar) village children. Am I Trop Med Hyg 1992;47:298-304.

252. Miller TL, Wolin MJ. Fermentations by saccharolytic intestinal bacteria. Am J Clin Nutr 1979;332:164-172

253. Kim YS, Spritz M, Blum M, Terz J, Sherlock P. The role of altered bile acid metabolism in the steatorrhea of experimental blind loop. I Clin Invest 1966;45:956962

254. Wanitschke R, Ammon HV. Effects of dilydroxy bile acids and hydroxy fatty acids on the absorption of oleic acid in the human jejunum. J Clin Invest 1978;61:178186

255. Shimoda SS, O'Brien TK, Saunders DR. Fat absorption after infusing bile salts into the human small intestine. Gastroenterology 1974;67:7.18

256. Garcey M, Thomas J, Houghton M. Effect of stasis on intestinal enzyme activities. Aust NZ I Med $1975 ; 5: 141-1.44$

257. Jonas A, Flanagan PR, Forstner GG. Pathogenesis of mucosal inury in the blind loop syndrome: brush border enzyme activity and glycoprotein degradation. I Clin Invest 1977:60:1321-1330

258. King $C$, Lorenz $\mathbb{E}$, Toskes $P$. The pathogenesis of decreased serum protein levels in the blind loop syndrome: evaluation including a newly developed A $_{\text {-amino acid }}$ breath test. Gastroenteroglogy 1976;70:901-913 
259. Armbrecht U, Bosaeus 1, Gillberg R, Seeberg S, Stockbrïgger R. Hydrogen (H2) breath test and gastric bacteria in acid-secreting subjects and in achlorhydirc and postgastrectomy patinets before and after antimicrobial treatment. Scand I Gastroenterol 1985;20:805-813

260. Browning GG, Buchan KA, Mackay $\mathrm{C}$. The effect of vagotomy and dramage on the small bowel flora. Gut 1974;15:139-142

261. Bjorneklett A, Fausa O, Midtvedt T. Small-Bowel Bacterial Overgrowth in the Postgastrectomy Syndrome. Scand J Gastroenterol 1983; 18:277-287

262. Drasar BS, Shiner M. Studies on the intestinal flora. Part II Bacterial flora of the small intestine in patients with gastrointestinal disorders. Gut 1969;10:812-819

263. Lock G, Hollerbach S, Linde HJ, Vogt W, Andus T, Schölmerich J, Holstege A. Bacterial overgrowth after gastric surgery: Comparison of endoscopic aspiration and glucose $\mathrm{H}_{2}$-breath test. Gastroenterology 1995;110:A343

264. Kumar A, Forsmark CE, Toskes PP. The response of small bowel bacterial overgrowith to treatment: Effects of coexisting conditions. Gastroenterology $1995 ; 110: A 340$

265. Venturi M, Zuccato E, Restelli A, Mazzoleni L, Mussini E, Doldi SB. Utility of hydrogen and methane breath tests in combination with $X$-ray atter a barium meal in the diagnosis of small bowel bacterial overgrowth after jejuno-ileal bypass for morbid obesisty. Obes Surg 1994;4:144-148

266. Willard MD, Simpson RB, Delles EK, Coben ND, Fossum TW, Kolp D, Reinhart G. Effects of dietary supplementation of fructo-oligosaccharides on small intestinal bacteriall overgrowth in dogs. Am J Vet Res 1994;55:654-659

267. Attar A, Bouhnik Y, Flourié B, Franchisseur C, Crenn P, Briet F, Ruszniewski P, Rambaud JC. Efficacy of two antibiotics and a probiotic in the treatment of small intestinal bacterial overgrowth. Gastroenterology 1995;110:A310

268. Stotzer PO, Blomberg L, Conway PL, Henriksson A, Abrahamsson H. Probiotic treatment of small intestinal bacterial overgrowth by Lactobacillus fermentum. Scand I Infect Dis 1996;28:615 619

269. Troidl H. Lebensqualităl: ein relevantes Zielkriterium der Chirurgie. Chirurg $1989 ; 60: 445-449$

270. Beckmann J, Ditley G. Conceptual Views on Quality of Life: An Impossible Task or a Necessary Challenge? Scand J Gastroenterol 1987:22:83-86

271. Visick H. Measured radical gastrectomy-a review of 505 operations for peptic ulcer. The Lancet 1948:1:505-510

272. Karnofsky DA, Abermann WA, Craver LF, Burchenal JH. The use of nitrogen mustards in the palliative treatment of carcinomas. Cancer 1948;1:634-656

273. Spitzer WO, Dobson AJ, Hall J. Measuring quality of life in cancer patients: a concise QL-index for use by physicians. J Chronic Dis 1981;34:585-597

274. Sakamoto K, Nakano G, Hashimoto I, Nagamachi Y. Potential usefulness of a physical activity index in the assessment of quality of life of patients after gastrointestinal surgery. Acta Chir Scand 1989;155:305-312

275. Egli H. What constitutes Quality of Life? Methodological Considerations and Suggestions for Clinical Practice. Scand J Gastroenterol 1987;22 Suppl 133:87-89 
276. Kusche J, Vestweber KH, Troidl H. Quality of Life after Total Gastrectomy for Stomach Cancer. Results of Three Types of Quality of Life Exaluative Methods. Scand J Gastroenterol 1987;22:96-101

277. Buhl K, Schlag P, Herfarth C. Quality of life and functional resulis following different types of resection for gastric carcinoma. Eur J Surg Oncol 1990;16:404409

278. Baron JH. What constitutes quality of life? A conceptualization of the Dimension of Life Quality in Cancer Patients. Scand J Gastroenterol 1987;22:93-95

279. Zieren HU, Zippel K, Zieren J. Müller JM. Quality of Life after Surgical Treatment of Gastric Carcinoma. Eur J Surg 1998;164:119-125

280. Stützer H. Die Analyse von Längsschnittdaten zur Lebensqualität am Beispiel des Magenkarzinoms. Köin: Medizinische Fakultät, Universität Köln. 1992 (Thesis)

281. Siegrist K. Siegrist J.Psychosocial Factors in the Course of Gastric Cancer. Scand J Gastroenterol 1987;22:90-92

282. Descottes B, Thognon P, Valleix D, Sodji M, Breuille G, Antarieu S. Gastrectomies rotales et viscerosynthese. J Chir Paris 1995; 132:3336-3341

283. Jentschura D, Strohmeier N, Winkler M, Sturm J. Comparative study of the quality of life after stomach resection. Langenbecks Arch Chir Suppl 1996;113:247-248

284. Korenaga D, Orita H, Okuyama T, Moriguchi S, Maehara Y, Sugimach K. Quality of life after gastrectomy in patients with carcinoma of the stomach. $\mathrm{Br}$. S Surg $1992 ; 79: 248-250$

285. Raab M, wan Maercke $P$, Stützer $H$. Quality of life following gastrectomy-a comparison of Longmire and Roux stomach replacement methods. Zentralbl Chir 1987;112:1140-1145

286. Svedlund J, Sullivan M, Liedman B, Lundell L, Sjodin I. Quality of Life after Gastrectomy for Gastric Carcinoma: Controlled Study of Reconstructive Procedures. World J Surg 1997:21:422-433

287. Shapiro DE, Rodrigue JR, Boggs SR, Robinson ME. Cluster analysis of the medical coping modes questionnaire: evidence for coping with cancer styles? I Psychosom Res 1994;38:151-159

288. Baider L, Perry S, Sison A, Holland J, Uuziely B. DeNour AK. The role of psychological variables in a group of melanoma patients. An Israeli sample. Psychosomatics. 1997;38:45-53

289. Graupe F, Schwenk. W, Bracht B, Kroner-Herwig B, Stock W. Psychological stress on patients in tumor after-care after $R 0$ resection of colorectal carcinomas. Chirurg 1996:67:604-609

290. Gross RE, Burnet CB, Borelli M. Coping responses to the diagnosis of breast cancer in postmastectomy patients. Cancer Pract 1996:4:204-211

291. Jacobson PB, Butler RW. Relation of cognitive coping and catastrophizing to acute pain and analgesic use following breast cancer surgery. J Behav Med 1996;19:17-29

292. Hulme Moir I. Psychological, social, and surgical factors which influence success or failure after gastric operations. Scand J Gastroenterol 1979;14:457-462

293. Wagner MK, Armstrong D, Laughlin JE. Cognitive determinants of quality of life after onset of cancer. Psychol Rep 1995:77:147-154 
294. Barkwell DP. Ascribed meaning: a critical factor in coping and pain attenuation in patients with cancer-related pain. J Palliat Care 1991;7:5-14

295. Faller $H$, Lang $H$, Schilling $S$. Causal "cancer personality" attribution- an expression of maladaptive coping with illness? Z Klin Psychol Psychopathol Psychther 1996;44:104-116

296. Feifel H, Strack S, Nagy VT. Degree of life-threat and differential use of coping modes. J Psychosom Res 1987;31:91-99

297. Spiegel D. Health caring. Psychosocial support for patients with cancer. Cancer 1994:74:1453-1457

298. Cunningham AJ, Lockwood GA, Edmonds CV. Which cancer patients benefit most from a brief, group, coping skills program? Int J Psychiatry Med 1993;23:383-398

299. Finlay IG, Jones OL. Hypnotherapy in palliative care. J R Soc Med 1996;89:493496

300. Grahn G. Coping with the cancer experience. I. Developing an education and support programme for cancer patients and their significant others. Eur I Cancer Care Engl 1996;5:176-181

301. Grahn G, Danielson M. Coping with the cancer experience. II. Evaluating an education and support programme for cancer patients and their significant others. Eur IJ Cancer Care Engl 1996;5:182-187

302. Grassi L, Rosti G. Psychosocial morbidity and adjustment to illmess among longterm cancer survivors. A six-year follow-up study. Psychosomatics 1996;37:523-532

303. Classen C, Koopman C, Angell K. Spiegel D. Coping styles associated with psychological adjustment to advanced breast cancer. Health Psychology $1996 ; 15: 434-437$

304. Dunkel-Schetter D, Feinstein LG, Taylor SE, Falke RL. Patterns of coping with cancer. Health Psychol 1992;11:79-87

305. Parle $M$, Jones $B$, Maguire $P$. Maladaptive coping and affective disorders among cancer patients. Psychol Med 1996;26:735-744

306. Wimmer H. Coping with disease by the patient. Results of a medico-sociological study of the coping process by cancer patients and possibilities for support by the physician. Wien Med Wochenschr 1991:141:90-95

307. Cella DF, Orav EJ, Kornblith AB, Holland JC, Silberfarb PM, Lee KW, Comis RL. Perry M. Cooper DF, Maurer LH. Socioeconomic status and cancer survival. J Clin Oncol 1991:9:1500-1509

308. Galloway SC, Graydon JE. Uncertainty, symptom distress, and information needs after surgery for cancer of the colon. Cancer Nurs 1996;19:112-117

309. Vinokur AD. Threatt BA, Vinokur-Kaplan D. The process of recovery from breast cancer for younger and older patients. Changes during the first year. Cancer 1990;65:1242-1254

310. Foltz A, Sullivan J. Reading level, learning presentation preference, and desire for information among cancer patients. J Cancer Educ 1996;11:32-38

311. Holland JC, Korzun AH, Tross S, Silberfarb P, Perry M, Comis R, Oster M. Comparative psychological disturbance in patients with pancreatic and gastric cancer. Am J Psy 1986;143:982-986 
312. Muthy FA, Bechtel M. Spaete M. Lay eteologic theories and coping with illness in severe physical diseases. An empirical comparative study of female myodardial infarct, cancer, dialysis and multiple sclerosis patients. Psychother Psyshosom Med Psychol 1992:42:41-53

313. Theissen HH. Coping with illness in the postoperative phase following gastrectomy. Z Gastroenterol 1996:34:29 31

314. Svediund J, Sullivan M, Sjodin I, Liedman B, Lundell L. Quality of life in gastric cancer prior to gastrectomy. Qual Life Res 1996;5:255-264 


\title{
Chapter II
}

\section{Patients and Methods}

\author{
R Brägelmann
}




\section{Patients}

\section{The "ideal" patient group}

The prognosis of most gastric cancer patients is sombre. Only for the proportion of patients with a much better prognosis, are long-term consequences of gastrectomy of interest.

Following this idea, the ideal patient group for a study on symptoms and nutrient malassimilation caused by total gastrectomy would consist of prospectively recruited patients who are curatively operated by a standardised operative procedure for lymphnode-negative early gastric cancer confined to the gastric mucosa. This would ensure the least pre-operative catabolic changes and the smallest risk of recurrence to interfere with the evaluation. However, in the following studies we pursued a more realistic approach for the following reasons.

There are many patients with more advanced stage tumour who are curatively operated and a restriction to early tumour stages might have given a biased impression of the whole group of gastric cancer patients. Furthermore, only ten percent of all diagnosed gastric cancers in Europe are early gastric cancers ${ }^{1}$. In combination with the other restrictive inclusion criteria the number of suitable study patients would have decreased considerably.

The restriction to a patient group with standardised operative procedure was not either desirable. The surgical heterogeneity of the patients has many positive aspects: standard procedures very often are not applicable because of anatomical reasons, decreasing recruitment percentage enormously $y^{2}$. In addition, specialised surgical centres will not necessarily perform all different types of surgical reconstruction with the same skill. This would make randomisation procedures problematic. The surgical parameters in our patients vary independently and, therefore, they reflect an averaged group of patients after total gastrectomy performed in different hospitals.

It would also be desirable to perform pre- and post-operative examinations on all patients to elucidate more clearly the changes induced by operation. However, the final determination whether a tumour was curatively resected or not is made after operation under the microscope. In a prospective study, a great number of patients with non-curable disease would have undergone pre-operative examinations which were of no clinical use to them.

These were the reasons why we preferred a retrospective survey of patients with curative resection of a gastric malignancy irrespective of the tumour stage at operation. In the following the selection procedures and their specific advantages and drawbacks are discussed in detail. 


\section{Selection to the rehabilitation centre}

During the period from May 1990 to January 1993, 196 consecutively admitted patients following a potentially curative total gastrectomy for gastric malignancy were seen at three German gastroenterological rehabilitation hospitals in Bad Kissingen, Bad Driburg, and Bad Brückenau. The first clinic mainly serves bluecollar workers, whilst the latter two preferably deal with patients employed in the public sector.

In Germany patients of "productive age" have the opportunity of post-operative admission to a rehabilitative centre. The patients admitted to these hospitals are almost always between 18 and 65 years of age, because the hospitals are owned by social security organisations which do not provide health care to retired personnel. Whilst the rehabilitation clinics combine medical and psychological expertise regarding chronic gastroenterological conditions, they are less equipped to deal with acute medical problems. The patients of this study, therefore, were electively referred for rehabilitative purposes of longer lasting medical problems of different degrees and had no acute disease.

In the case of post-gastrectomy the admission to the rehabilitation centre occurs normally months to years after the operation. In the setting of this study, the referral was either done by the general practitioner or by specialists, who thought rehabilitation to be useful for their patient. The total number of patients who had undergone a curative total gasirectomy during the recruitment period in the region and the number of patients not referred to rehabilitation are not known as there is no central register for stomach cancer in Germany. This study, therefore, does not provide any epidemiological answers as the age-restriction, disease severity, and non-standardised referral practices of general practitioners and/or specialists result in selection biases for the admission to the rehabilitation clinics.

The advantages of the rehabilitative setting for this study are the combination of specific medical and psychological expertise and a special emphasis on the evalluation and the treatment of chronic medical problems compared to the standard clinical settings.

\section{Selection to the study group}

Only patients with a potentially curative resection as stated by the surgeon on the basis of macroscopic appearance and microscopic evaluation of the resection margins were considered as candidates for this study. This reflects the moment at study entry. There was no prospective follow-up of the included patients. Clearly, these patients constitute a subgroup of gastric cancer patients with a much better prognosis than the overall group of gastric cancer patients. However, such a selection was intended for the special purpose of this study; i.e. the investigation of the pathophysiology and therapy of nutrient malassimilation of patients after total 
gastrectomy supposedly free of cancer recurrence. Demographic and medical data concerning the time before admission to the rehabilitation centres was allocated as completely as possible by contact with the hospital where the patient had been operated on. Special emphasis was given to study the surgical records. In a few patients, however, surgical procedures and reconstruction cannot be given in detail because of the recruitment procedure.

The time span between operation and admission in the revalidation centres was recorded to examine or to control for possible time-related adaptive changes in the patients.

Of the 196 patients, 14 were admitted for the second time to the rehabilitation centres, and in eight patients a cancer recurrence and/or metastasis was diagnosed shortly after admission. These 22 patients were not included in this study. The remaining 174 patients ( $\mathrm{f}=63, \mathrm{~m}=111$; median age 58 (IQR 50 to 66) years) had been admitted 206 days (median; IQR 56 to 691 ) after the potentially curative total gastrectomy (Figure II.1). $27 \%$ of the patients were admitted within the first two months after the total gastrectomy and $39 \%$ of the patients after more than one year.

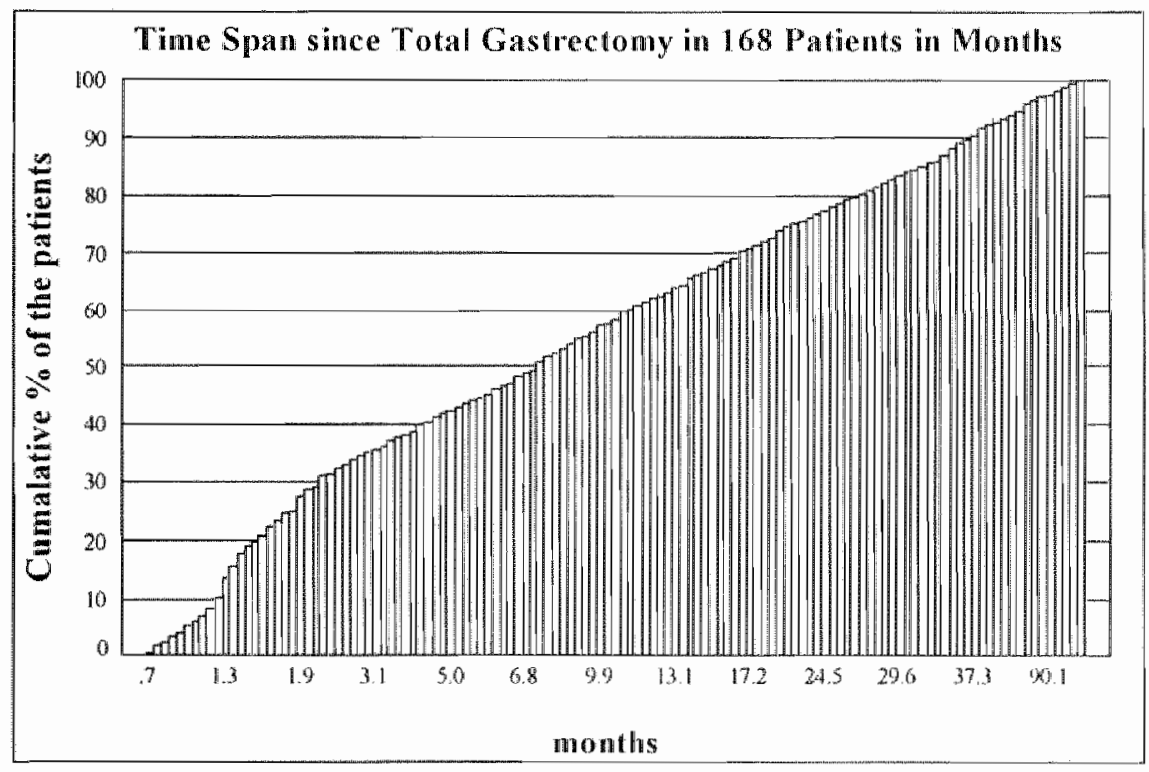

Figure 11.1 Time span since total gastrectomy in 168 patients in monthe. Given is the distribution of the time between operation and admission in the revalidation centres in 1.68 patients after total gastrectomy. In 6 cadses values were missing. 


\section{Methods}

\section{Study design}

After clinical, biochemical and haenatological evaluation on admission, patients were put on a standardised diet for a period of five days during which symptoms, bowel habits, calorie intake and fat assimilation were evaluated. Thereafter, a $\mathrm{H}_{2}$. breath test with radiopaque markers, and an oesophago-intestinal endoscopy were performed. Patients with a faecal fat output of $\geq 14 \mathrm{~g} /$ day were asked to participate in an intervention study with pancreatic enzyme supplementation. Informed conseni was obtained. The intervention study was of randomised double-blind, placebocontrolled design. Participants of the intervention study started placebo or enzyme treament on day 14 after admission. During the last five days of intervention, they were re-examined according to the same protocol $a s$ in the beginning. Figure II.2 gives an outline of the study design.

\begin{tabular}{|c|c|c|c|c|c|c|c|c|c|c|c|c|c|c|c|c|c|c|c|c|c|c|c|c|c|c|c|}
\hline 1 & 2 & 3 & 4 & 5 & 6 & 7 & 8 & 9 & 10 & 11 & 12 & 13 & 14 & 15 & 16 & 17 & 18 & 19 & 20 & 21 & 22 & 23 & 24 & 25 & 26 & 27 & 28 \\
\hline \multirow{2}{*}{$\frac{1}{1}$} & & & & & & & & & & & & & & & & & & & & & & & & & & & I \\
\hline & & & \multicolumn{5}{|c|}{ Dict } & & & & & & & & & & & & & & & \multicolumn{5}{|c|}{ Diet } & \\
\hline & & & \multicolumn{5}{|c|}{ Symptom Score } & & & & & & & & & & & & & & & \multicolumn{5}{|c|}{ Symplom Score } & \\
\hline & & & \multicolumn{5}{|c|}{ Faecall Frequency } & & & & & & & & & & & & & & & \multicolumn{5}{|c|}{ Faccal Frequency } & \\
\hline & & & \multicolumn{5}{|c|}{ Faecral Consistency } & & & & & & & & & & & & & & & \multicolumn{5}{|c|}{ Faecal Consistency } & \\
\hline & & & \multicolumn{5}{|c|}{ Caloric Intake } & & & & & & & & & & & & & & & \multicolumn{5}{|c|}{ Caloric Intake } & \\
\hline & & & & & \multicolumn{3}{|c|}{ Faecal Fat } & & & & & & & & & & & & & & & & & \multicolumn{3}{|c|}{ Faccal Fat } & \\
\hline & & & & & & & & & $\mathrm{IW}$ & & & & & & & & & & & & & & & & & & \\
\hline & & & & & & & & & & 0 & & & & & & & & & & & & & & & & & \\
\hline & & & & & & & & & & & & & & rHel & ton & & & & & & & & & & & & \\
\hline
\end{tabular}

Figure 11.2

Study Design I denotes standarised interview for symptoms; B denotes standarised clinical, biochemical, and haematological evaluation; $\mathbf{H}$ denotes $\mathrm{H}_{2}$ breath test with radiopaque markers: $O$ denotes oesophago-intestinoscopy

\section{Assessment of body mass index and weight development}

Body mass was measured applying the Quetelet index (mass/height ${ }^{2}$; normal range 20.0 to $25.0 \mathrm{Kg} / \mathrm{m}^{2}$ ) using anamnestic data for weight in health and measured weight on operation and admission.

\section{Registration of symptoms}

Symptoms reported often after total gastrectony according to the literature (see Table 1.3, page 15) were evaluated. Symptoms were recorded in two different ways: 1) On admission and at discharge patients were asked for the presence of the following symptoms: dyspepsia, meteorism, early satiety, reflux, dysphagla, and 
postprandial vomiting. 2) During the period of controlled diet faecal frequency (number/day) and faecal consistency (scale 0 to 3, "none" to "watery diarrhoea") were registered, and symptoms were scored ( 0 to 3 , "none at all" to "severe") daily by the patients according to a questionnaire (Figure II.3). The means of the five-day score of all three parameters was reported in all patients. The means of the specific symptoms asked during the controlled-diet period were reported in 71 patients of one centre (Marbachtalklinik). In the following the data on symptoms of the period with controlled diet are referred to as "symptom score" in the distinction from the summarising symptom registration on hospital admission and at discharge.

\begin{tabular}{|l|l|l|l|l|l|l|}
\hline DAY & 1 & 2 & 3 & 4 & 5 & mean \\
\hline faecal frequency & & & & & & \\
\hline faecal consistency & & & & & & \\
\hline & 1 & 2 & 3 & 4 & 5 & mean \\
\hline meteorism & & & & & & \\
\hline early satiety & & & & & & \\
\hline dyspepsia & & & & & & \\
\hline nausea & & & & & & \\
\hline dumping & & & & & & \\
\hline dysphagia & & & & & \\
\hline vomiting & & & & & & \\
\hline sum of means & & & & \\
\hline sum of means $/ 7=$ symptom score & & \\
\hline
\end{tabular}

Figure I1.3 Evaluation of the symptom score

\section{Controlled diet period}

Patients on pancreatic enzyme supplementation at the time of hospital admission were asked to discontinue this for at least three days. This wash-out time is sufficient, since proteolytic enzymes cause a marked loss of lipase activity ${ }^{3}$.

All patients were then put on a standardised diet for five days to ensure a stable "dietary equilibrium". During the diet period, meals were composed of $48 \%$ fat, $17 \%$ protein, and $35 \%$ carbohydrates, respectively. The standardisation of the meals ensured that symptomatic and biochemical data acquired during this period could be related to energy intake in the statistical work-up. The individual intake was not restricted, but was quantified at every meal by an attending dietician and 
summarised each day. In this way, the energy intake of the patients and the possible influence of intervention with pancreatic enzyme supplementation on energy intake could be evaluated at the same time. The evaluation of fat assimilation is not hindered by this non-restricted approach, as fat malassimilation is not proportional to intake over a large range of fat consumption ${ }^{4.5}$.

\section{Fat malassimilation}

During the last three days of the controlled diet period faecal mass and faecal fat output were assessed, the latter according to the method of van de Kamer. The idea of fat balance studies lasting more than one day had already been mentioned by van de Kamer".

\section{Exocrine pancreatic function}

In one centre, Bad Kissingen, chymotrypsin concentration and output per 72 hours was measured to evaluate the exocrine pancreatic function. Normal values for the latter are 504-34769 U/72 hours?. The value of faecal chymotrypsin concentration in the evaluation of severe exocrine pancreatic insufficiency has been documented by Ammann et al. ${ }^{8}$. Although the faecal chymotrypsin concentration after total gastrectomy has a low specificity for exocrine pancreatic insufficiency ${ }^{9}$, it was chosen because all the other alternative non-invasive tests have the same problem but are not as easy to perform. The faecal elastase-1 test ${ }^{10}$ was not described yet when this study was started. It might have been of great interest for the evaluation. Invasive tests to evaluate pancreatic function after total gastrectomy are hindered by post-operative anatomy and rule out any study in a large proportion of patients.

\section{Endoscopy}

An upper endoscopy was performed in each patient, unless it had been performed during the previous two months to evaluate for oesophagitis and to ensure control of local recurrence. In patients who had an endoscopy a short time before admission, it was attempted to allocate endoscopic records as completely as possible from hospitals and private practioners who had performed the endoscopy according to the patients. Howwer, in 90 patients $(52 \%)$ no endoscopic records were availlable.

\section{Oro-coecal transit time and bacterial overgrowth as assessed with the $\mathrm{H}_{2}$-breath test in combination with radiopaque markers}

A hydrogen breath test was chosen to assess the presence of rapid oro-coecal transit, as scintigraphic facilities were not available in all centres and as the presence of small bowel bacterial overgrowth could be assessed at the same time 
with this method.

\section{Theoretical background}

\section{Substrates}

For the hydrogen breath test, substrates must contain an adequate amount of carbohydrate. To obtain reliable test results, the composition of the substrates should be tailored to the purpose of the investigation.

To study oro-coecal transit time by means of an $\mathrm{H}_{2}$-breath rest, the substrates should contain unabsorbable or only partially absorbable carbohydrates and should not influence the transit time themselves. Lactulose accelerates small bowel transit time ${ }^{11,12}$ and should therefore not be used in this context. A more physiological approach has been described using standard meals ${ }^{13-16}$.

To study small bowel bacterial overgrowth, the substrate should be available for bacterial metabolism of the whole small intestine and not accelerate oro-coecal transit time, because this would hinder the interpretation of an early $\mathrm{H}_{2}$ rise. Lactulose $^{17,18}$, glucose ${ }^{17.19-22}$, xylose $e^{22-27}$, and standard meals rich in carbohydrate ${ }^{13 .}$ ${ }^{16,28}$ have been used.

\section{Cut-off points}

An increase of the $\mathrm{H}_{2}$-concentration $50 \%$ above the values at 90 and at 120 minutes has been described to correlate well with the entry of radiopaque markers in the coecum $^{14}$. Sarno et al. described a very sophisticated method to determine coecal entry using shifting medians of $\mathrm{H}_{2}$-concentrations and reported a $100 \%$ rise above baseline values to be as good as the method mentioned above $\mathrm{e}^{29}$. Others have used "absolute values" in a range of five to $20 \mathrm{ppm} \mathrm{H}_{2}$ to define entry of different substrates into the coecum $20,22,24,28,30,31$.

\section{Test qualities}

Measurement of oro-coecal transit time with the $\mathrm{H}_{2}$-breath test compares well with scintigraphic methods, which must be considered the "gold standard". Bond et al." found a close correlation $(r=0.97)$ of the oro-coecal transit time assessed by the transit of polyethylene glycol and an $\mathrm{H}_{2}$-breath test using lactulose. Armbrecht et al. ${ }^{14}$ compared an $\mathrm{H}_{2}$-breath test using a test meal with radiopaque markers and had comparable results $(r=0.90)$. Similarly, Read et al. reported a correlation coefficient $(r=0.88)$ between a scintigraphic method and a breath test using a solid meal $^{32}$. Reproducibility of the measurements with lactulose is good and a coefficient of variation of $14 \%$ is documented". For tests using a test meal this value is reported to be below ten percent ${ }^{33}$. The normal oro-coecal transit time measured with either scintigraphic methods or $\mathrm{H}_{2}$-breath test with meals is about four hours ${ }^{13.14,3440}$. Assessment of transit times below 60 minutes is problematic, because oral flora ${ }^{41}$ and the gastro-colic reflex can cause a slight transit rise of 
$\mathrm{H}_{2}$-concentration in the breath.

The following table (Table II. I) lists the reported sensitivity and specificity for the diagnosis of small bowel bacterial overgrowth compared to intestinal cultures as reference examination. As substrates and patient groups are different, these values vary to a certain degree.

Table II. Sensitivity and specificity of the $\mathrm{H}_{2}$-breath test in the assessment of small bowel bacterial overgrowh

\begin{tabular}{|c|c|c|c|}
\hline \multirow[t]{2}{*}{ Author } & \multirow[t]{2}{*}{ year } & \multicolumn{2}{|c|}{ small bowel bacterial overgrowth } \\
\hline & & sensitivity & specificity \\
\hline Asmbrecht ${ }^{38}$ & 1987 & 77 & 93 \\
\hline Chang" & 1995 & $60(90)$ & $90(100)$ \\
\hline CoratzZat & 1990 & 68 & 44 \\
\hline Lewis & 1997 & 71 & 94 \\
\hline Lock ${ }^{19}$ & 1995 & 73 & 66 \\
\hline $\operatorname{Lock}^{23}$ & 1996 & 74 & 94 \\
\hline
\end{tabular}

- values without and with correction for gastric emptying rate; "* the examined patient group included patients with jejuno-ileal bypass. Bacterial overgrowth/coecal entry of the substrate was differentiated purely on the basis of the $\mathrm{H}_{2}$-breath test

Although intestinal cultures are considered to be the "gold standard" for the diagnosis of bacterial contamination, there are some drawbacks to this method. Focal contamination of the bowel, which not necessarily is sampled with a proximal tube or endoscope, might be of influence. This especially might be important for post-operative situations with stagnant loops. Studies assessing this problem are scare and results are diverging ${ }^{17.42}$. The problem of segmental variation of bacterial density and subsequent sampling problems, therefore, still is under discussion ${ }^{21}$.

\section{Limitations and problems of the $\mathrm{H}_{2}$-breath test}

There are a number of factors influencing the reliability of the $\mathrm{H}_{2}$-breath test of which some are listed in Table II.2.

One problem with the $\mathrm{H}_{2}$-breath test is, that some authors could not find any $\mathrm{H}_{2}$ produciion in a few patients $s^{43}$. These patients are referred to as "non-producers". The reported frequency of non-producers ranged from "occasionally" to $20 \%$. In the study by Gilat" however, patients who had had antibiotic treatment were included which makes interpretation difficult. Furthermore, diets rich in cereals might exert an imhibiting effect on colonic bacterial flora ${ }^{45}$. 
Table 11.2 Factors interfering with the $\mathrm{H}_{2}$-breath test

\begin{tabular}{ll}
\hline & Heconcentration \\
\hline Antimicroblat therapy & decreased \\
Preparation for colonoscopy & decreased \\
Diarnoea & decreased \\
Acidic pH of the faeces & decreased \\
Hyperventilation & decreased \\
Smoking & increased \\
Strach containing diet the day before the examination & increased \\
H, non-producer & decreased to none \\
\hline
\end{tabular}

adapted from Armbrecht ${ }^{43}$

\section{Definition of rapid intestinal transit}

The time point of 75 minutes to define rapid intestinal transit was chosen for two reasons: 1 . In a pilot study with a small group of patients after total gastrectomy ${ }^{46}$, relevant weight loss was seen in those patients with a transit below 60 minutes. 2 . The methodological problems of the $\mathrm{H}_{2}$-breath test with transit times below 60 minutes as mentioned above.

\section{Description of the test procedure in detail}

Rapid upper intestinal transit - defined as an oro-coecal transit time below 75 minutes $^{46}$ - and small bowel bacterial overgrowth were evaluated simultaneously using a modification of the $\mathrm{H}_{2}$-breath test described by Armbrecht et al. ${ }^{14}$. Medical records were scrutinised to ensure that no antimicrobial treatment had been given during the two previous weeks. After a low-fibre diet during the day before the test and an overnight fast ${ }^{4}$, end-expiratory $\mathrm{H}_{2}$-concentrations were serially analysed every 15 minutes, starting 15 minutes prior to the test breakfast, the composition of which is shown in Table M.3.

Ten radiopaque markers $(6.0 \times 1.8 \mathrm{~mm})$ were added to the test meal to indicate transit into the coecum. $\mathrm{H}_{2}$-concentrations were measured with a GMI Exhaled $\mathrm{H}_{2}$ Monitor (GMI Medical Lid., Inchinnan Estate, Renfrew, Scotland). Samples were taken by direct insufflation via a $Y$-piece with flow reduction ${ }^{47}$. Duplicate samples were taken at each time point, and the arithmetic mean of these two measurements was used for evaluation. Seventy-five minutes after the start of the breakfast a plain abdominal $\mathrm{x}$-ray was taken to detect oro-coecal transit shorter than 75 minutes. If the first radiopaque marker(s) had reached the coecal area or the ascending colon, the patient was assumed to have a rapid oro-coecal transit. 
Table 11.3 Composition of the standard test meal for the combined assessment of the oro-coecal transit the and upper gastrointestinal bacterial owargrowth

\begin{tabular}{lccc}
\hline Water & 150 & $\mathrm{ml}$ \\
Porridge made from & water & 200 & $\mathrm{ml}$ \\
& milk & 50 & $\mathrm{ml}$ \\
White bread & rolled odts & 36 & $\mathrm{~g}$ \\
Margarine & & 50 & $\mathrm{~g}$ \\
Cheese (16\% fat) & 10 & $\mathrm{~g}$ \\
Smoked medwurst & 13 & $\mathrm{~g}$ \\
Total encrgy content & 12 & $\mathrm{~g}$ \\
Energy contribution from carbohydrate & 2.0 & $\mathrm{MJ}$ \\
10 ratdiopaque markers & 39 & $\%$ \\
\hline
\end{tabular}

In this case the further examination was stopped. In all other cases a second radiograph was taken when a $100 \%$ rise occurred above base line values of breath $\mathrm{H}_{2}$-conceniration, in order to differentiate between upper intestinal bacterial overgrowth and transit of the test meal into the colon. If markers were identified in the colon, the time point was recorded as the oro-coecal transit time. If markers were still in the small intestine, it was concluded that oro-coecal transit was longer than the time period measured and that patients had small intestinal bacterial overgrowth. The test was ended at 210 minutes irrespective of markers having reached the colon or not. Therefore, absolute values for transit time below 75 minutes and above 210 minutes cannot be given in this paper. Patients with an orocoecal transit time longer than 210 minutes were evaluated mathematically as having an oro coecal transit time of 210 minutes. Figure II.4 exemplifies four possible test results.

\section{Medico-social functioning as an assessment of quality of life}

In order to assess medico-social functioning the Edinburgh Rehabilitation Status Scale (ERSS) was applied on admission by one of the authors on the day of admission. The ERSS ranges from 0 to 28 points, with higher figures indicating a poorer medico-social functioning. The ERSS measures the dimensions of medicosocial performance in four different subscales: Independence/dependence, activity/ inactivity, social integration/social isolation, and effects of symptoms on lifestyle. These subscalle points are summed up to the final score. In one centre the specific subscales were recorded as well.

The Edinburgh Rehabilitation Status Scale was chosen for this study for several 
reasons: 1) It has been tested in several somatic patient groups in rehabilitative medicine including patients after gastrectomy for gastric cancer ${ }^{43-53}$. 2) It encompasses physical, psychological, as well as social parameters. 3) The interrater reliability is good ${ }^{50}$ and there is good correlation to the Barthel Index and the Pulses profile ${ }^{s_{2}}$. 4) It is easy to perform and very time efficient.

Table II.4 gives the final scores for different patient groups as reported by Affleck et al. ${ }^{50}$.

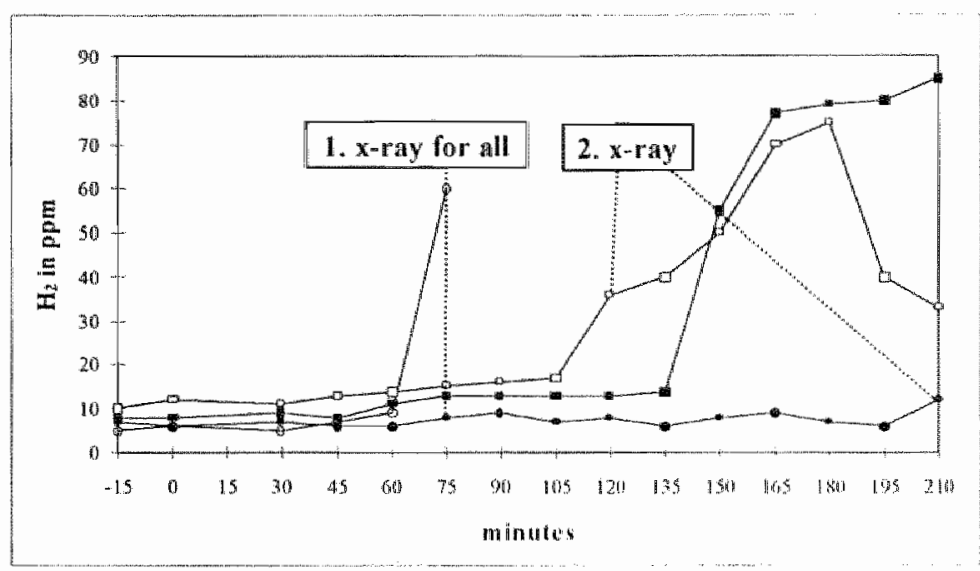

Figure II.4 Measurement of oro-coecal transit time in patients after total gastrectomy with normal or with rapid oro-coecal transit (OCTT<75 minutes). Examples of $\mathrm{H}_{z}$ breath tests with a test breakfatst as used in this study. The line with the filled circles denotes a patient without bacterial overgrowth and an orocoecal transit time exceeding 210 minutes. The line with the black squares denotes at patient without bacterial overgrowth in whon markers were indentified in the ascending colon at 150 minutes. The line with the white squares denotes a patient with bacterial overgrowth. At 120 minutes there is a rise in $\mathrm{H}_{2}$-concentration, but markers were identitied in the small intestine; the OCTT could theretore not be measured. The line with the white circles denotes a patient with an oro-coecal transit time below 75 minutes as the $\mathrm{H}_{2}$-values were already rising and radiopague matkers were identitied in the ascending colon at 75 minutes. 
Table 11.4 Mean Edinburgh Rehabilitation Status Scale (ERSS) scores in different patient groups

\begin{tabular}{lc}
\hline Patient groups & ERSS \\
\hline Upper limb \& neck lesions & 7.7 \\
Back-pain syndromes & 9.8 \\
Arthritis & 10.0 \\
Cardiac & 14.9 \\
Amputation & 15.4 \\
CNSi excluding CVA & 16.7 \\
CVA & 18.0 \\
Muttiple impairments & 18.3 \\
\hline
\end{tabular}

\section{Assessment of coping behaviour}

All patients included in the study at Bad Kissingen were invited to see the clinical psychologist for a personal or, if preferred, written interview to evaluate coping behaviour. The patients were totally free in their decision to accept this invitation or to decline the offer. No reasons were inquired if patients choose not to participate.

In order to assess coping behaviour the "Freiburger Fragebogen zur Krankheitsverarbeitung - FKV 102 " of Muthny et al. "was used. This questionnaire has been developed to assess coping and social support. It can either focus recrospectively on the moment when the patient was told the diagnosis, or on the week before the interview. The latter procedure was followed in this study. The questionnaire consists of 102 items which have to be rated by the patient in a range from one to five reflecting "not fitting at all" to "fits perfectly". The items are related to twelve scales which are given in the following table (Table M.5). Higher numbers indicate that a pattern is more important for the patient.

Primarily, the predilection of the patients for the specific patterns was described with an intra-scale comparison. Thereafter, the degree to which the individual scales are applied by our patients was compared with a disease-control group from the licerature consisting of patients with chronic renal insufficiency $(n=212)$ and patients with breast cancer $(n=107)^{54}$. Finally, the following variables were analysed with regard to the possible influence on coping strategies: tumour stage, time past operation, gender, weight loss since operation, and energy intake per kilogram body weight and day. For this evaluation the patients were re-grouped into three tumour groups, as prognosis and/or therapy of these groups differ substantially: group I with stage IA gastric cancer $(n=17)$, group 2 with stage IB to IV gastric cancer $(n=27)$, and group 3 with gastric lymphoma $(n=6)$. 
Table II.5 Scales of the "Freiburger Fragebogen zur Krankheitsverarbeitung" (FKV 102) and examples of some items

\begin{tabular}{|c|c|c|c|c|}
\hline & Scales of the FKV 102 & Example of an ittem* & \multicolumn{2}{|c|}{ raghe } \\
\hline 1 & problem analysis \& problem solving & I rned to find the cause of my disonse & 13 & 65 \\
\hline 2 & depression & I was dapressed and sal & 16 & 80 \\
\hline 3 & hedonist & I diof songething ance today & 11 & 59 \\
\hline 4 & raligion search for reason & Throughth the disense, Ifound myed & 8 & 40 \\
\hline 5 & pessunistic behaviour \& distrustuness & I fell dominated by the doctors & 7 & 35 \\
\hline 6 & cognitive dentall bo dissimulation & I wanted to thear that it was not all that bot & i) & 45 \\
\hline 7 & distraction \& sell-applatisat & I triad lo doget & 8 & 40 \\
\hline 8 & cmotional control \& social isolation & I wanted fo too alone & 7 & 35 \\
\hline 9 & regressive tendency & I wished that If were allowed to be weak & 5 & 25 \\
\hline 10 & ralativation by comparison & I got strengh. because others liwed through if & 4 & 20 \\
\hline 11 & compliance strategy \& irust in doctors & I did exactly what any doctor told me & 4 & 20 \\
\hline 12 & self-support & I reliad on my ontimism and hasl for life & 5 & 25 \\
\hline
\end{tabular}

"Ttanslation from the German by the author

\section{Statistics and figures}

Throughout this thesis continuous variables are given as means with standard error of the mean (SEM) or medians with the interquartile range (IQR). A p-value of 0.05 was used to indicate significance unless stated otherwise.

In chapter III the Students "T-test for independent samples together with Levene's test for equality of variances, and the $x^{2}$-test with Fisher's exact test where necessary were used.

Statistical calculations in chapter IV consisted of the $\chi^{2}$ - test and ANOVA-models using a Bonferroni correction for three-group-comparisons with a p-value of 0.017 indicating significance.

For chapter $V$ statistical calculations included the Mann-Whitney- $U$ test for independent samples, the Wilcoxon-test for paired samples, and the $\chi^{2}$-test, with Fisher's exact test in cases necessary. An ANOVA model was applied to assess the influence of pre-treatment differences in the test groups.

Statistical calculations used in chapter VI were the $\chi^{2}$-tests and Mann-Whitney $\mathrm{U}$ test.

In chapter VII statistical calculations included the $\chi^{2}$-tests. General factorial ANOVA-models and multiple logistic regression models were used to control for difference in time since operation.

To elucidate the factors influencing medico-social functioning, a linear regression analysis (mode enter) was performed with all the available variables. To account for missing values we substitued the mean value (continuous values) or zero (categorical variables) for the missing value and included a missing indicator 
variable in the analysis.

In chapter $[X$, the specific scales of the FKV 102 were compared with each other by means of a Wilcoxon Matched-Pairs Signed-Ranks Test with a Bonferroni correction. A p-value of $0.013(0.05 / 4)$ was used to indicate significance. The possible influence of five variables on coping strategies was analysed in linear regression models with a Bonferroni correction. A p-value of $0.004(0.05 / 12)$ was used to indicate significance.

Figures used were whisker-boxplots, scatter plots, column scatter plots, histograms and line diagrams. 


\section{References}

1. Everett SM, Axon ATR. Early gastric cancer in Europe. Gut 1997:41:142-150

2. Troidl H, Kusche J, Vestweber JH, Eypasch E. Maul U. Ponch versus oesophagojejunuostomy after total gastrectomy: A randomized clinical trial World J Surg 1987;11:699-7!2

3. DiMagno EP. Paterns of Human Exocrine Pancreatic Secretion and Fate of Human Pancreatic Enzymes During Aboral Transit. In: Lankisch PG ed. Pancreatic Enzymes in Health and Disease. Berlin, Springer Verlag 1991:1-10

4. Schwartz MK, Bodansky O, Randal L. Metabolism in surgical patients. II. Fat and mineral metabolism in totally gastrectomized patients. Am J Clin Nutr 1956;4:51-60

5. Bradley EL, Isaacs J, Hersch $T$, Davidson ED, Milikan W. Nutritional consequences of total gastrectomy. Ann Surg 1975;182:415 429

6. van de Kamer JH, ten Bokkel Huinink H, Weyers HA. Rapid method for the determination of fat in faeces. J Biol Chem 1949;177:347-355

7. Stockbrügger RW, Armbrecht U. Determination of Faecal Chymotrypsin Concentration and 72-Hour Faecal Chymotrypsin Output in the Detection of Pancreatic Steatorrhoed. Scand J Gastroenterol 1991;26:13-19

8. Ammann R, Tragwercher E, Kashiwagi H, Rosemund H. Diagnostic value of fecal chymotrypsin and trypsin assessment for detection of pancreatic disease. Am I Dig Dis 1968;13:123-146

9. Heptner G, Domschke S, Domschke W. Exocrine Pancreatic Function After Gastrectomy - Specificity of Indirect Tests. Gastroenterology 1989;97:147-153

10. Stein J, Schoonbroodt $D$, Jung $M$, Lembcke B, Caspary WF. Measurement of fecal elastase 1 by immunoreactivity: a new indirect test of the pancreatic function. Gastroenterol Clin Biol 1996;20:424-429

11. Bond JH Jr, Levitt MD, Prentiss R. Investigation of small bowel transit time in man utilizing pulmonary hydrogen $\left(\mathrm{H}_{2}\right)$ measurements. I Lab Clin Med 1975:85:546-555

12. Miller MA, Parkman HP, Brown KL, Donahue DJ, Knight LC, Urbain J-L, Maurer AH, Fisher RS. The lactulose breath test is not a physiologic standard for orocoecal transit: Lactulose delays gastric emptying and accelerates small bowel transit. Gastroenterology 1995; 108:A650

13. Korth $H$, Müller I, Erkenbrech JF, Wienbeck M. Breath hydrogen as a test for gastrointestinal transit. Hepatogastroenterology 1984;31:282-284

14. Armbrecht U, Jensen J, Eden S, Stockbrügger RW. Assessment of Oro-coecal Transit Time by Means of a Hydrogen $\left(\mathrm{H}_{2}\right)$ Breath Test As Compared with a Radiologic Control Method. Scand J Gastroenterol 1986;21:669-677

15. Malagelada JR, Robertson JS, Brown ML, Remington M, Duenes JA, Thomforde GM, Carryer PW. Intestinal Transit of Solid and Liquid Components of a Meal in Health. Gastroenterology 1984;87:1255-1263

16. Read NW, Cammack J, Edwards C. Holgate AM, Cann PA, Brown C. Is the transit time of a meal through the small intestine related to the rate at which it leaves the stomach? Gut 1982;23:824-828 
17. Corazza GR, Menozzi MG. Stocchi A, Rasciti L, Varia D, Lecchini R, Avanzini $P$, Chezai $C$. Gasbaririni $G$. The diagnosis of small bowel bacterial overgrowth. Reliability of jejunal culture and inadequecy of breath hydrogen testing. Gastroenterology 1990;98:302-309

18. Haboubi NY, Montgomery RD. Small-bowel bacterial overgrowth in elderly people: clinical significance and response to treatment. Age-Ageing 1992;21:13-19

19. Lock $G$, Hollerbach $S$, Linde HJ, Vogt $W$, Andus $T$, Schölmerich $J$, Holstege A. Bacterial overgrowth after gastric surgery: Comparison of endoscopic aspiration and glucose $\mathrm{H}_{2}-$ breath test. Gastroenterology 1995; 110:A343

20. Casellas F, Guarner L, Vaquero E, de Gracia $X$, Antolín M, Malagelada J-R. Intestinal bacterial overgrowth in pancreatic insufficiency. Gastroenterology 1995: 108: A346

21. Lembcke, B. Current Role of Breaih Tests in Gastroenterology. Z Gastroenterol 1996:4:46-53

22. Lock $\mathrm{G}$, Hollerbach $S$, Linde HJ, Vogt W, Andus $T$, Schölmerich J, Holstege A. Bacterial overgrowth after gastric surgery: Comparison of endoscopic aspiration and glucose $\mathrm{H}_{2}$-breath test. Gastroenterology 1996;4:A343

23. Chang $\mathrm{CS}$, Chen $\mathrm{GH}$, Kao $\mathrm{CH}$, Wang SJ, Peng $\mathrm{SN}$, Huang $\mathrm{CK}$, Poon SK. Increased accuracy of the carbon-14 D-xylose breath test in detecting smallintestinal bacterial overgrowth by correction with the gastric emptying rate. Eur $J$ Nucl Med 1995;22:1118-1122

24. Briet F, Attar A, Flourié B, Bouhnik, Maurel M, Franchisseur C, Descos L, Rambaud JC. Does the ${ }^{13} \mathrm{C}$-xylose breath test improve the accuracy of the $\mathrm{H}_{2}$-breath test for the diagnosis of bacterial overgrowth of the small intestine. DDW A 4014

25. Dellert SF, Nowicki MJ. Farrell MK, Delente J, Heubi JE. The ${ }^{13} \mathrm{C}$-xylose breath test for the diagnosis small bowel bacterial overgrowth in children. I Pediatr Gastroenterol Nutr 1997;25:153-158

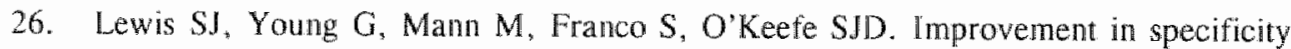
of $\left.\right|^{14} \mathrm{Cl}$-xylose breath test for bacterial overgrowth. Dig Dis Sci 1997:42:15871592

27. Riordan SM, Mclver Cd, Duncombe VM, Bolin TD, Thomas MC. Factors influencing the $1-\mathrm{g}{ }^{14} \mathrm{C}-\mathrm{D}$-Xylose breath test for bacterial overgrowth. Am J Gastroenterol 1995:90:1455-1460

28. Armbrecht U. Eden $S$. Seeberg $S$, Stockbrügger RW. The Value of the Hydrogen (H2) Breath Test for the Diagnosis of Bacterial Overgrowth in Gastric Achlohydria. Hepatongastroenterol 1987;34:219-222

29. Sarno S, Erasmus LP, Halsbeck M, Holzl R. Orocaecal transit-time by the $\mathrm{H}_{2}$ method: effects of definitions of caecal entry and test meal. Ital J Gastroenterol 1993:25:55-64

30. Sallzman JR, Kowdley KV, Pedrosa MC, Sepe T, Golner B, Perrone G, Russel RM. Bacterial overgrowth without clinical malabsorption in elderly hypochlorhydric subjects. Gastroenterology 1994:107:1214-1215 
31. Palitzsch K-D, Holstege A, Braun B, Lock $G$, Zietz B, Schömerich I. Frequency of small bowel bacterial overgrowth in diabetes mellitus type I and type II. Gastroenterology 1996; 4: A352

32. Read NW, Al-Janabi MN, Holgate AM, Barber DC, Edwards CA. Simultaneous measurement of gastric emptying, small bowel residence and colonic filling of a solid meal by the use of the gamma camera. Gut 1986;27:300-308

33. La Brooy SJLA, Male PJ. Beavis AK, Misiewicz JJ. Assessment of the reproducibility of the lactulose $\mathrm{H}_{2}$-breath test as a measure of mouth to caecum transit time. Gut 1983;23:893-896

34. Argenyi ES, Soffer EE, Madsen MT, Berbaum KS, Walkner WO. Scintigraphic evaluation of small bowel transit in healhy subjects: inter- and intrasubject variability. Am J Gastroenterol 1995;90:938-942

35. Maurer AH, Krevsky B. Whole-gut transit scintigraphy in the evaluation of smallbowel and colon transit disorders. Semin Nucl Med 1995;25:326-338

36. Malageladla IR, Robertson JS, Brown ML, Remington M, Duenes JA, Thomforde GM, Carryer PW. Intestinal Transit of Solid and Liquid Components of a Meal in Health. Gastroenterology 1984;87:1255-1263

37. von der Ohe MR, Camilleri M. Measurement of small bowel and colonic transit: indications and methods. Mayo Clin Proc 1992;67:1169-1179

38. Camilleri M, Colennont LJ, Phillips SSF, Brown ML, Thomforde GM, Chapman $\mathbb{N}$, Zinsmeister AR. Human gastric emptying and colonic filling of solids characterized by a new method. Am J Physiol 1989;257:284-290

39. Kerlin P, Byrnes $O$, Wong L. Radiolabelled unprocessed bran: Validation of a practical labelling technique and evaluation of gastrointestinal profiles in health. J Gastroenterol Hepatol 1989;4:119-126

40. Camilleri $M$. Zinsmeister AR, Greydanus MP, Brown ML, Proano M. Towards a less costly but accurate test of gastric emptying and small bowel transit. Dig Dis Sci $1991 ; 36: 609 \cdots 615$

41. Read NW, Al Janabi MN, Bates TE, Hogate AM, Camn PA, Kinsman RI, McFarlane A, Brown C. Interpretation of the breath hydrogen profile obtained after ingesting a solid meal containing unabsorbable carbohydrate. Gut 1985;26:834-842

42. Tillman $R$, King $C$, Toskes P. Continued experience with the xyllose breath test: evidence that the small bowel culture as the gold standard for bacterial owergrowth may be tarnished. Gastroenterology 1981;80:1304

43. Armbrecht U. Hydrogen $\left(\mathrm{H}_{2}\right)$ Breath Test in Man. Studies under experimantal conditions and in clinical practice. Göteborg, 1988 (Thesis)

44. Gilat T, Ben Hur H. Gelman-Malachi E, Terdiman R. Peled Y. Alterations of the colonic flora and their effect on the hydrogen breath test. Gut 1978;19:602-605

45. Vogelsang H, Ferenci P. Frotz $S$, Meryn $\$$, Gang A. Acidic colonic microclimatepossible reason for lalse negative hydrogen breath test. Gut 1988;29:21-26

46. Armbrecht U, Lundell L, Lindstedt $\mathrm{G}_{*}$ Stockbrügger RW. Causes of malabsorption after total gastrectomy with Roux-en-Y reconstruction. Acta Chir Scand $1988 ; 154: 37-4$ 
47. Brummer RJM, Armbrecht U. Bosaeus I, Dotevall G, Stockbrügger RW. The Hydrogen $\left(\mathrm{H}_{2}\right)$ Breath test. Sampling Methods and the Influence of Dietary Fibre on Fasting Level. Scand J Gastroenterol 1985;20:1007-1013

48. Gutschmidt $\$$, Hänisch $S$, Wurthner $K$. Verlaufsbeschreibung stationärer Rehabilitation bei Verdauungs-und Stoffwechselkrankheiten unter zunehmender Integration von Verhalten und Erleben. Rehabilitation 1993;32:185-196

49. Gutschmidt $\mathrm{S}$, Hänisch $\mathrm{S}$. Integrativer Therapieansatz in der stationären Rehabilitation von Frauen und Männern mit totaler Gastrektomie wegen Magenkarzinom. Rehabilitation 1994;33:228-236

50. Affleck JW, Aitken RCB, Hunter IAA, McGuire RJ, Roy CW. Rehabilitation Status: A Measure of Medicosocial Dysfunction. Lancet 1988;1:230-233

51. Disler PB, Christopher WR, Smith BP. Predicting Hours of Care Needed. Arch Phys Med Rehabil 1993;74:139-143

52. Mattison $P G$, Aitken $C B$, Prescott RJ. Rehabilitation status-the relationship between the Edinburgh Rehabilitation Status Scale (ERSS), Barthel Index, and PULSES profile. Int Disabil Studies 1991;13:9-11

53. Mattison PG, Aitken CB, Prescott RJ. Rehabilitation status in multiple handicap. Arch Phys Med Rehabil 1992;73:926-929

54. Muthny FA. Freiburger Fragebogen zur Krankheitsverarbeitung. Manual. Verlag Beltz, Weinheim 1989 


\section{Chapter III}

\section{Nutrient Malassimilation Following Total Gastrectomy}

R Brägelmann, U Armbrecht, D Rosemeyer, B Schmeider, W Zilly, R Stockbrügger

Scand J Gastroenterol 1996; 31 Suppl 218:26-33 


\section{Abstract}

\section{Background}

The aim of the study was to elucidate the degree and the pathophysiology of abdominal symptoms, malnutrion and malassimilation after total gastrectomy.

\section{Methods}

In 174 consecutive patients, with potentially curative total gastrectomy for gasiric malignancy, subjective symptoms and objective parameters of malassimilation were evaluated.

\section{Results}

Abdominal symptoms were present in $86 \%$ of the patients. In spite of a high daily calorie intake (median $37.8 \mathrm{kcal} / \mathrm{kg}$ body weight) mean body mass index had been decreasing since good health. Anaemia was found in $46 \%$, sideropenia in $31 \%$, and oesophagitis in $26 \%$. Mean faecal fat excretion was $17.4(1.4)$ grams/day and mean fat malassimilation $14.8 \%$ (SEM 1.1) of the intake. A shortened small bowel transit was measured in $21.7 \%$ of the patients, and bacterial overgrowth was present in $37.7 \%$.

\section{Conclusions}

Malassimilation post total gastrectomy seems to be multifactorial. Shortened small bowel transit and subsequent dyssynchrony of pancreatic enzyme supply seem to be of major importance. 


\section{Introduction}

After total gastrectomy anorexia, abdominal symptoms, and weight loss caused by tumour recurrence and/or nutrient malassimilation are frequently feared by patients and physicians. Nutrient malassimilation can be caused by malnutrition and maldigestion/malabsorption as a result of anorexial-4, rapid upper intestinal transit ${ }^{5}$, the type of operation ${ }^{6-12}$, upper intestinal bacterial overgrowth ${ }^{5}$, lack of gastric lipase ${ }^{13}$, primary or secondary exocrine pancreatic insufficiency ${ }^{14-18}$, and pancreatico-cibal dyssynchrony ${ }^{19-25}$. The aim of this study was to evaluate a large group of patients after potentially curative total gastrectomy with special reference to dietary habits, nutritional status, and objective parameters of nutrient malassimilation, and to present a preliminary analysis of possible pathophysiological mechanisms.

\section{Patients and Methods}

During the period from May 1990 to January 1993182 consecutive patients who had had a potentially curative total gastrectomy for gastric malignancy, were evaluated in a prospective study at three German gastroenterological rehabilitation hospitals in Bad Kissingen, Bad Driburg, and Bad Brückenau. In eight patients $(4.4 \%)$ a recurrence and/or metastasis was diagnosed shortly after admission. The remaining 174 patients $(f=63, m=111$, mean age 57.6 (SEM 0.8 ) years) were included in further evaluation.

\section{Study Design}

After clinical evaluation on admission, participants were put on a standardised diet for a period of five days during which symptoms, bowel thabits, callorie intake and fat assimilation were evaluated. Thereafter, a $\mathrm{H}_{2}$-breath test with radiopaque markers, and an oesophago-intestinal endoscopy were performed.

\section{History, physical and biochemical examination}

On admission a standardised history was taken and an attempt was made to obtain detailed surgical reports. A careful physical examination and a standardised biochemical evaluation were performed.

\section{Registration of symptoms and signs}

Symptoms were recorded in two different ways. When admitted to hospital patients were presented with a standardised questionnaire asking whether they suffered from 
a number of abdominal symptoms. During the period of controlled diet abdominal complaints, faecal frequency, and faecal consistency were scored daily according to a questionnaire in all patients. A five-day-score of each specific parameter was reported in 71 patients of one centre (Figure III.1).

\begin{tabular}{|l|l|l|l|l|l|l|}
\hline DAY & 1 & 2 & 3 & 4 & 5 & mean \\
\hline faucal frequency & & & & & & \\
\hline fatecal consistency & & & & & & \\
\hline & 1 & 2 & 3 & 4 & 5 & mean \\
\hline meteorism & & & & & & \\
\hline early satiety & & & & & & \\
\hline dyspepsia & & & & & & \\
\hline nausea & & & & & & \\
\hline dumping & & & & & & \\
\hline dysphagia & & & & & \\
\hline vomiting & & & & & & \\
\hline Sum of means & & & & \\
\hline sum of means $/ 7=$ symptom score & & \\
\hline
\end{tabular}

Figure III.I Evaluation of the symptom scure. On every day of the controlled diet period patients were questioned. Faecal frequency per day was noted. Faecal consistency was ranked $0=$ no faleces, $1=$ normally formed, $2=\operatorname{soft}, 3=$ watery diarthoen and the fiveday-mean is given. Symptoms were ranked: $0=$ no, $1=$ few, 2 =intermediate, 3 =severe symptoms. The five-day-mean of these parameters was noted. The symptom score was calculated as the sum of the means of the spectioc symptoms devided by seven.

\section{Dietary evaluation and controlled diet period}

Patients who were on pancreatic enzyme supplementation at the time of hospital admission were asked to discontinue this. The controlled diet period of five days started three to five days following admission. The diet was composed of $48 \%$ fat, $17 \%$ protein and $35 \%$ carbohydrates respectively, and was not limited quantitatively. However, individual nutritional intake was quantified during the controlled diet period at every meal by an attending dietician and summarised each day. 


\section{Faecal analyses and fat assimilation}

Faecal fat output was assessed during the last three days of the controlled diet period according to the method of van de Kamer ${ }^{26}$. Fat assimilation was calculated as the proportion $(\%)$ of fat excreted compared with the intake.

\section{$\mathbf{H}_{2}$-breath test}

Oro-coecal transit time and upper intestinal bacterial overgrowth were determined by an $\mathrm{H}_{2}$-breath test using a standardised breakfast with ten radiopaque plastic markers added to it according to Armbrecht et al..$^{27}$ using a GMI Exhaled Monitor with $\mathrm{H}_{2}$ selective and sensitive electrochemical cells (GMI Medical Ltd, Inchinnan Estate, Renfrew, Scotland). 15 minutes prior to the breakfast basal $\mathrm{H}_{2}$-breath concentrations were determined. After the breakfast a double sample of endexpiratory air was examined, and thereafter every 15 minutes. 75 minutes after breakfast a radiograph was taken to determine whether the plastic markers had reached the colon. If the markers were not in the colon a second radiograph was taken when the $\mathrm{H}_{2}$-concentration was $100 \%$ above the mean of the baseline concentration, or 210 minutes after breakfast, when the examination was ended.

\section{Endoscopy}

The upper endoscopy was performed in each patient, unless it had been performed during the previous two months. In these cases the endoscopic diagnosis from the last examination was noted.

\section{Weight development}

Body mass was evaluated using the Quetelet index (weight/height, $\mathrm{kg} / \mathrm{m}^{2}$ ). The normal range was assumed to be 20.0 to 25.0 . Pre-operative body mass was estimated according to anamnestic data, body mass index at the time of operation was taken from the hospital records, and on admission the body mass index was measured.

\section{Statistics}

Statistical calculations included the Students 'T-test for independent samples together with Levene's test for equality of variances, and the $\chi^{2}$-test with Fisher's exact test where necessary. A p-value of $<5 \%$ was assumed to be statistically significant. 


\section{RESULTS}

\section{Demographical parameters}

Patient characteristics and postoperative care are given in Table III.1. More than half of the patients were admitted during the first post-operative year. 75 percent of the patients with gastric cancer had been operated on for UICC tumour stages ${ }^{28}$ beiter than III. The most frequent operation was an oesophago-jejunostomy with a jejuno-jejunostomy Roux-en- $Y$ without pouch formation $(\mathrm{n}=80,48.8 \%$ ).

Table III.I Gender, age, time since operation, cancer stage, type of operation in $\$ 74$ patients after total gastrectomy

\begin{tabular}{|c|c|c|c|c|}
\hline & mean & SEM & $\mathbf{n}$ & $\%$ \\
\hline Gender & & & 174 & \\
\hline Mate & & & 111 & 63.8 \\
\hline Female & & & 63 & 36.2 \\
\hline Age (in years) & 57.6 & 0.8 & 172 & \\
\hline Time since OP (days) & 567 & 82 & 168 & \\
\hline Tumourstage (UICC) & & & 174 & \\
\hline 0 & & & 4 & 2.3 \\
\hline $\mathbb{I A}$ & & & 48 & 27.6 \\
\hline IB & & & 38 & 21.8 \\
\hline II & & & 23 & 13.2 \\
\hline IIIA & & & 22 & 12.6 \\
\hline IIIB & & & 8 & 4.6 \\
\hline IV & & & 7 & 4.0 \\
\hline None (Iymphomas) & & & 24 & 13.8 \\
\hline \multicolumn{5}{|l|}{ Type of operation } \\
\hline poruch and continuous duodenal passige & & & 4 & 2.3 \\
\hline pouch without continuous dundenall passage & & & 27 & 15.5 \\
\hline no pouch without continuous duodenal passage & & & 88 & 50.6 \\
\hline no pouch with continuous duodenal passage & & & 22 & 12.6 \\
\hline onther & & & 22 & 12.6 \\
\hline anknown & & & 11 & 6.3 \\
\hline
\end{tabular}




\section{Symptoms and bowel habits}

On admission $86 \%$ of the patients complained of abdominal symptoms, consisting of meteorism, dyspepsia, early satiety, reflux, dysphagia, and vomiting (Table III.2).

Table III.2 Frequency of symptoms on admission in 174 patients after total gastrectomy

\begin{tabular}{lrc}
\hline Total & 150 & $86.2 \%$ \\
Dyspepsia & 115 & $65.5 \%$ \\
Early Satiety & 96 & $55.2 \%$ \\
Reflux & 46 & $26.4 \%$ \\
Dysphagid & 36 & $20.7 \%$ \\
Vomiting & 2.1 & $12.1 \%$ \\
Meteorism & 48 & $67.6 \%$ \\
\hline
\end{tabular}

"Meteorism was only asked for in 71 patients

During the period of controlled diet meteorism and early satiety were the most frequent and severe symptoms. However, the overall symptom score was low (Table III.3).

Table III.3 Frequency and severity of symptoms as expressed in total symptom score and specific symptom scores during the controlled diet period in 71 patients after total gastrectomy

\begin{tabular}{lcccc}
\hline & $\mathrm{n}$ & $\%$ & mean $^{*}$ & SEM \\
\hline Total symptom score & 71 & & 0.414 & 0.039 \\
Specific symptom score & & & & \\
Meteorism & 54 & 76 & 1.331 & 0.128 \\
Early satiety & 35 & 49 & 0.742 & 0.108 \\
Dyspepsia & 18 & 25 & 0.304 & 0.079 \\
Nausea & 13 & 18 & 0.188 & 0.062 \\
Dumping & 12 & 17 & 0.206 & 0.065 \\
Dysphagia & 9 & 13 & 0.137 & 0.054 \\
Vomiting & 4 & 6 & 0.046 & 0.031 \\
\hline
\end{tabular}

* range 0.000-3,000

$23 \%$ of the patients had more than two stools per day. In $46.5 \%$ the faecal consistency was reported as being soft to watery. 


\section{Haematological and biochemical analysis}

Haematological and biochemial data are given in Table MII.4.

Table MI.4 Hawmatological and biochemical parameters on hospital admission

\begin{tabular}{lccccc}
\hline & normal range & unit & $\mathrm{n}$ & mean & SEM \\
\hline Haemoglobin & $133-177$ & $\mathrm{~g} / 1$ & 170 & 134.2 & 1.2 \\
Ferrition & $20-400$ & $\mu \mathrm{g} / 1$ & 165 & 95.0 & 12.7 \\
Altumin & $35.2-50.4$ & $\mathrm{~g} / \|$ & 164 & 43.7 & 0.5 \\
Calcium corrected for albumin & $2.2-2.5$ & mmol/1 & 163 & 2.40 & 0.02 \\
Chymotrypsinoutput & $504-34769^{\circ}$ & $\mathrm{U} / 72 \mathrm{hrs}$ & 61 & 3246 & 303 \\
\hline
\end{tabular}

- according to Stockbrügger et at

In patients without iron supplementation $(n=138)$ anemia was present in $48.6 \%$ of the cases. Ferritin was subnormal in $26.7 \%$ and decreasing with time (Figure III.2). When the ten patients with iron supplementation on admission were included in the evaluation, those values were 46 and $31 \%$ respectively.

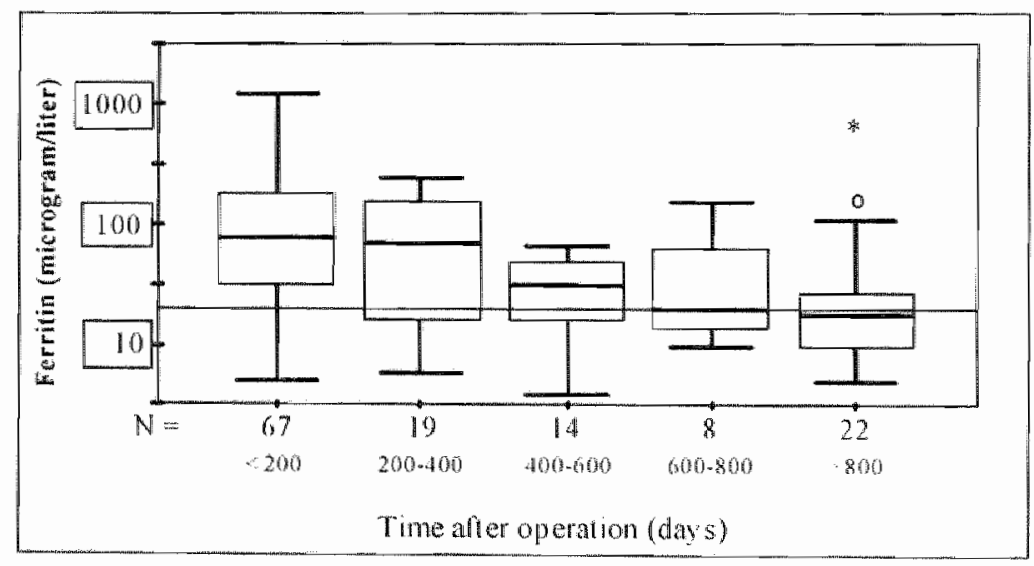

Figure III.2 Development of iron deficiency in 130 patients without iron supplementation after total gastrectomy. In this whisker-boxplot the lower boundary of the boxes is the

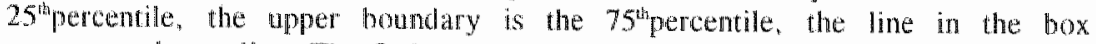
represents the median. The $O$ denotes an outlier, which is defined as a case with a value 1.5 tot 3 box-lenghts from the edge of the box. Cases more than 3 boxlenghts from the upper or lower end of the box are designated with an asterix. The whiskers show the highest and lowest values that are not outlers. Ferritin values are in $\mu \mathrm{g} / \mathrm{L}$ (on a logarithmic scalle) and time after operation is given in days. The furorizontal line denotes the lower normal ferritin value of $20 \mu \mathrm{g} / \mathrm{l}$. Of the 174 patients, ten patients had iron supplementation on admission, the iron supplementation status of 22 patients was not known, ferritin values of 9 patients were missing, and the time after operation of five patients was not exactly known. These values are not given in the tigure. 
Hypocalcaemia was found in $7 \%$ of the patients and hypercalcaemia in $20 \%$. The mean chymotrypsin output was in the lower normal range with $19 \%$ of the patients showing subnormal values ${ }^{29}$.

\section{Dietary habits and controlled diet period}

$62.6 \%$ of the patients had had dietary advice after operation. The number of meals per day exceeded three in $90 \%$ of the cases with $75 \%$ having at least five meals a day. Food intolerance was present in $62.4 \%$, with milk as the most frequently addressed single agent in $18 \%$. Half of the patients had a caloric intake of more than 2347 kilocalories (median 37.8 kilocalories per $\mathrm{kg}$ body weight per day). $25 \%$ of the patients consumed even more than $43.1 \mathrm{kcal} / \mathrm{kg}$ body weight per day (Figure III.3).

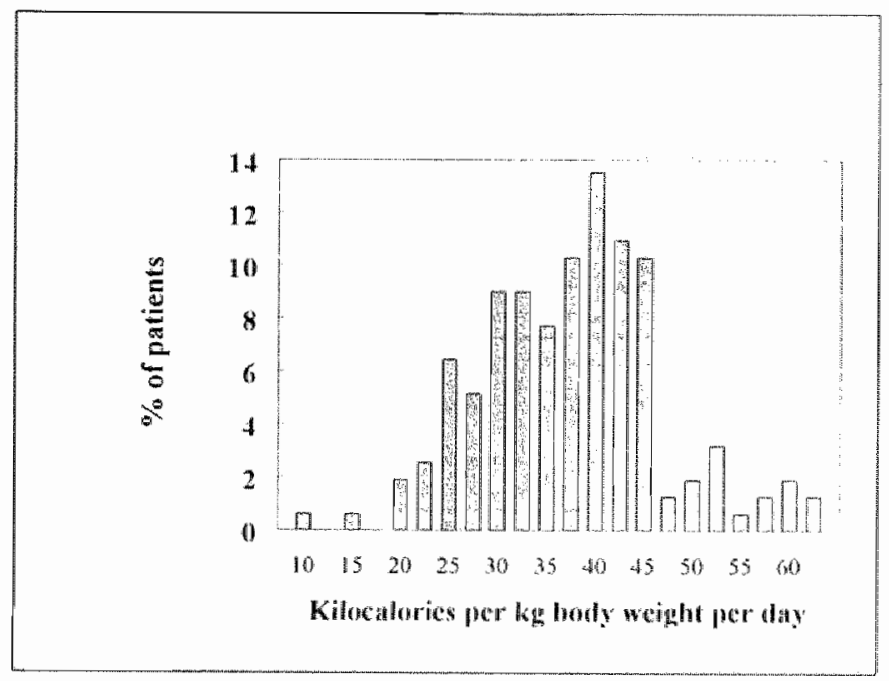

Figure III.3 Calorie intake of 162 patients after total gastrectomy. The distribution of the mean calorie intake per kilogram body weight per day during the controlled diet period is shown. The bars denote a range of 2.5 kilocalories/kg body weight beginning with the number given. The median was 37.8 , the $25^{\text {th }}$ percentile 30.4 and the $75^{\text {th }}$ percentile 43 . I kilocalories $/ \mathrm{kg}$ body weight Values were missing with regards to 12 patierts.

\section{Faecal analysis and fat assimilation}

Mean faecal mass was 252 (SEM 13) grams/day. Mean faecal fat excretion was 17.4 (SEM 1.4) grams/day and mean fat malabsorption was 14.8 (SEM 1.1) \% (Figures III.4-6). 


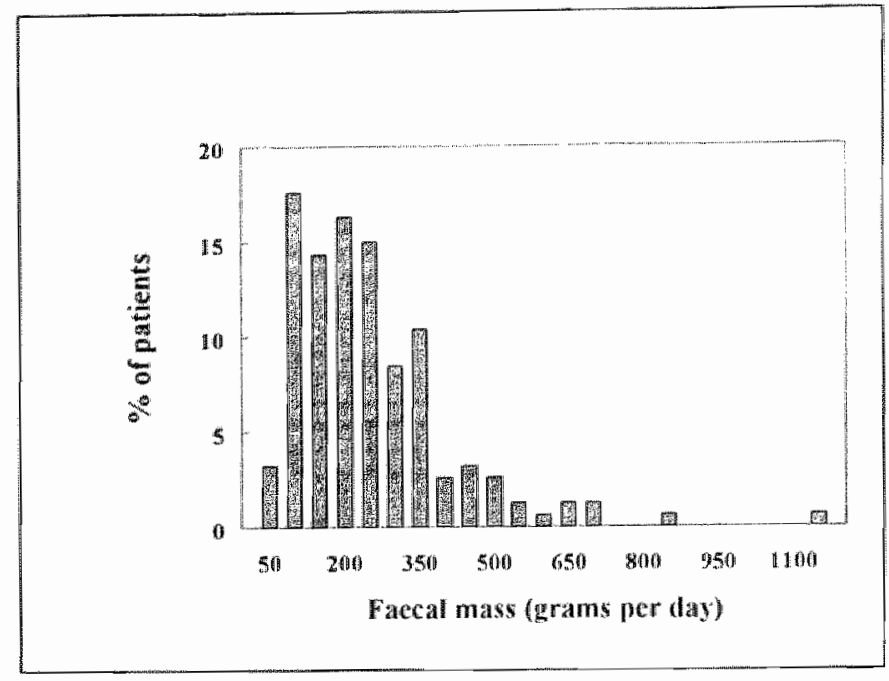

Figure III.4 Faecal mass per day in 153 patients after total gastrectomy. Faeces was collected over 72 hours and faecal mass was measured. The bars denote a range of 50 grams beginning with the number given. The median was 219 , the $25^{\text {th }}$ percentile 139 , and the $75^{\text {th }}$ percentile 322 grams per day. Values were missing for 21 patients.

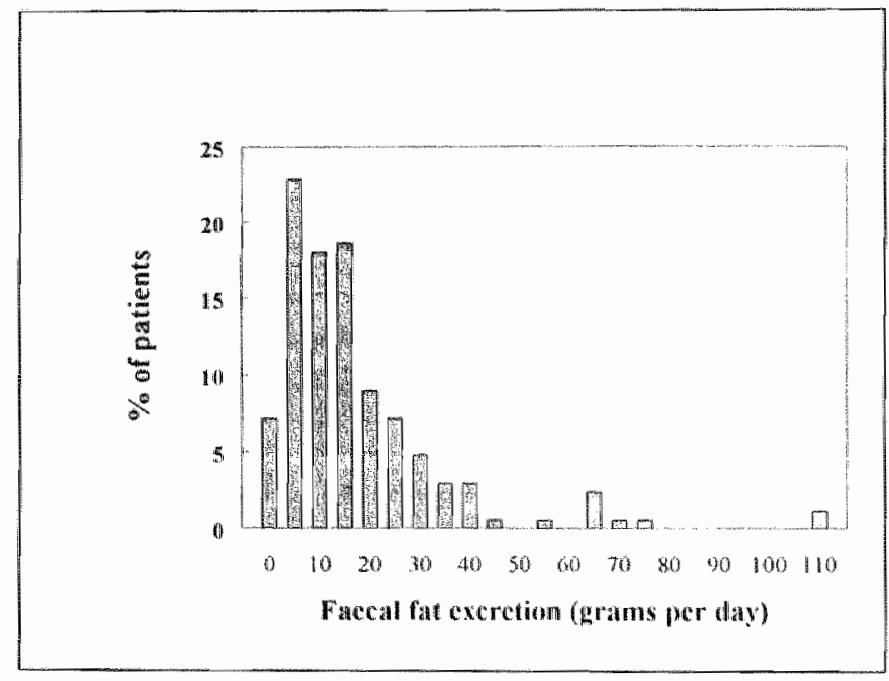

Figure III.5 Fuecal fat excretion per day in 166 patients after total gastrectomy. The bars denote at range of 5 grams beginning with the number given. The median was 12.9 , the $25^{\text {th }}$ percentile 6.2 , and the $75^{\text {th }}$ percentile 21.6 grams per day. Values were missing for 8 patients. 


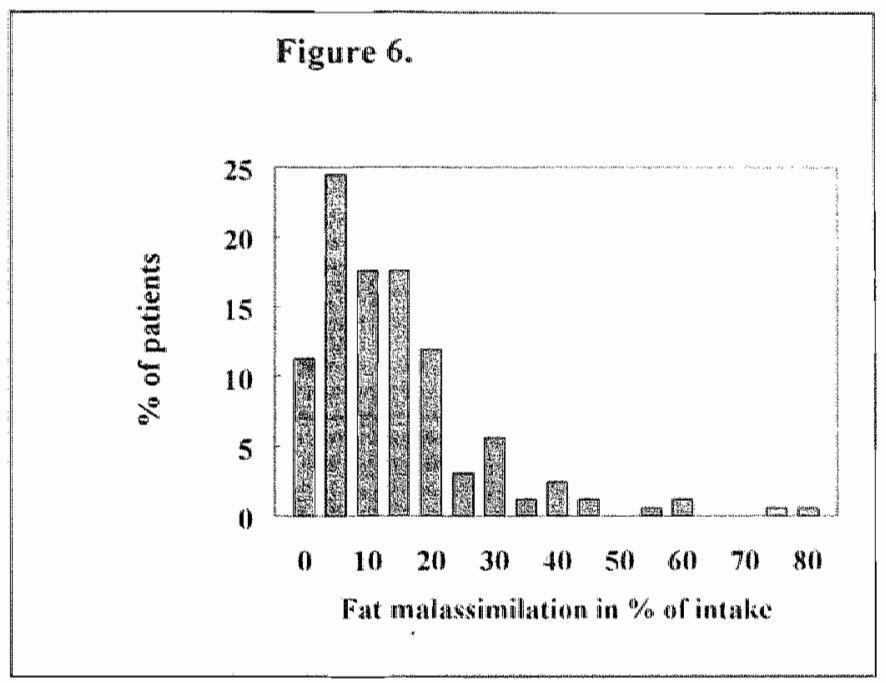

Figure III.6 Fat malassimilation in 159 patients atter total gastrectomy. Fat malassimilation was calculated as fat excretion divided by fat intake multiplied with 100 . The bars denote a range of $5 \%$ beginning with the number given. The median was 11.6 , the $25^{\text {th }}$ percentile 5.1 , and the $75^{\text {th }}$ percemtile $19.6 \%$. The values for fat excretion or fat intake were missing for 15 patients and the calculation could not be made.

\section{Endoscopy and $\mathrm{H}_{2}$-breath test}

Endoscopic data were available in 84 of the 174 patients $(48.2 \%)$. At endoscopy $67 \%$ had a normal postoperative anatomy, $26 \%$ oesophagitis, $4 \%$ retention of food, and $4 \%$ a stenosis. Patients in whom endoscopic findings were present significantly more often had reflux symptoms $(p<0.01)$ compared with the others.

Using the $\mathrm{H}_{2}$-breath test an oro-coecal transit shorter than 75 minutes was found in $21.7 \%$ of the patients, while the mean transit time in the others was 202 (SEM 4.0) minutes (Table III.5) $37.7 \%$ of the evaluated patients showed signs of bacterial overgrowth of the upper intestine (Table III.5). 
Table III.5 Frequency of bacterial overgrowth and rapid oro-coecal transit (according to the $\mathrm{H}_{2}$-breath test with radiopaque markers) after lotal gastrectomy

\begin{tabular}{lrr}
\hline Bacterial overgrowth & $\mathrm{n}=17.4$ & $\%$ \\
yes & 49 & 37.7 \\
no & 81 & 62.3 \\
not evaluable & 44 & 25.2 \\
Rapid oro-coecal transit & $\mathrm{n}=174$ & 21.7 \\
yes & 35 & 78.3 \\
no & 130 & 5.2 \\
not evaluable & 9 & \\
\hline
\end{tabular}

\section{Weight development}

Mean body mass index according to Quetelet $\left(\mathrm{kg} / \mathrm{m}^{2}\right)$ was $26.61(0.31)$ preoperatively, $24.17(0.33)$ at operation, and $22.06(0.23)$ on admission. $96 \%$ of the patients had lost weight pre-operatively, and $67 \%$ had lost weight since the operation. While $13.4 \%$ had a body mass index of less than 20 Quetelet-points at operation, this was the case with $25 \%$ of the patients on admission (Figure III.7).

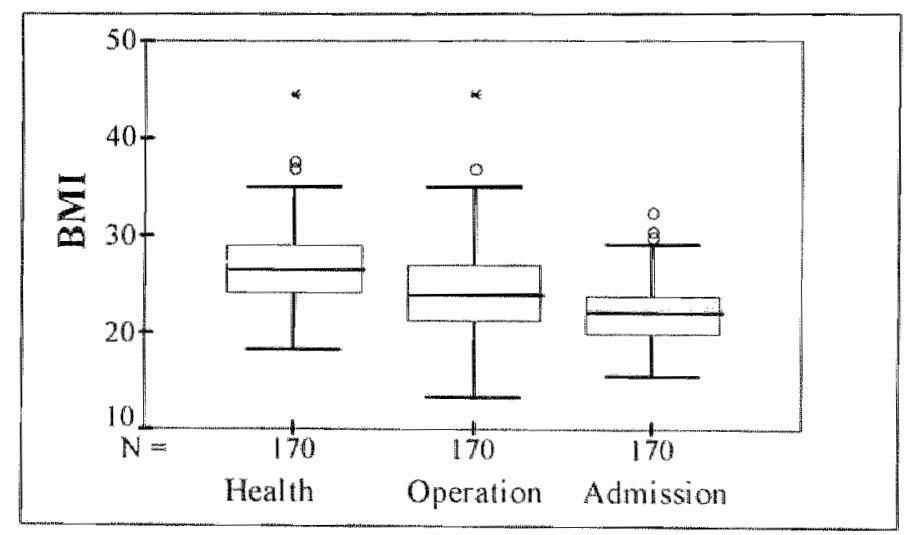

Figure 111.7 Development of the body mass index of 170 patients after total gastrectomy. The body mass index (BMI) according to Quetelelt (weight/height ${ }^{2}$ ) is given. BMI in health is anamnestically estimated, at operation taken from the hospital records, and on admission measured in the rehabilitation centers. The definition of the whisker-boxplots is as in figure III.1. 


\section{Preliminary analysis of possible pathophysiological mechanisms of nutrient malassimilation after total gastrectomy}

\section{Calorie intake}

In a univariate subgroup analysis of patients with low calorie intake $(<30 \mathrm{kcal} / \mathrm{kg}$ body weight per day) and of patients with higher calorie intake ( $\geq 30 \mathrm{kcal} / \mathrm{kg}$ body weight per day) it was found that the latter reported significantly less early satiety and vomiting, whilst meteorism was more frequent. Faecal mass, faecal fat, and bowel frequency were significantly higher in the group with higher calorie intake. The percentage of fat malassimilation was, however, similar. Body mass index when healthy and on admission were significantly higher in the group with low calorie intake, but this was not the case at the time of operation. Patients with a higher calorie intake had lost more weight since being operated on. (Table III.6).

Table III.6 Difterences in patients after total gastrectomy divided according to low and high callorie intake per $\mathrm{Kg}$ body weight and day

\begin{tabular}{|c|c|c|c|c|c|c|c|c|}
\hline & \multicolumn{3}{|c|}{$<30 \mathrm{kcal} / \mathrm{kg}$ body weight } & \multicolumn{3}{|c|}{$\geq 30 \mathrm{kcall} / \mathrm{kg}$ body weight } & \multirow[t]{2}{*}{$\mathrm{p}$} \\
\hline & & $\mathbf{n}$ & mean & $\mathrm{SEM}$ & n & mean & SEM & \\
\hline \multirow[t]{3}{*}{ BMI } & in hedith & 36 & 28.1 & 0.7 & 117 & 26.0 & 0.4 & *** \\
\hline & at operation & 36 & 25.2 & 0.7 & 118 & 23.4 & 0.4 & nis \\
\hline & on admission & 36 & 24.1 & 0,6 & 118 & 21.3 & 0.2 & 象冰将 \\
\hline \multirow[t]{2}{*}{ Change } & in $\mathrm{BMI}$ & & & & & & & \\
\hline & operation - admission & 36 & 1.0 & 0.6 & 118 & 2.3 & 0.3 & * \\
\hline \multicolumn{9}{|c|}{ \% change in $\mathrm{BMI}$} \\
\hline & operation - admission & 36 & 2.7 & 2.6 & 118 & 8.4 & 1.1 & $*$ \\
\hline \multicolumn{2}{|c|}{ Severity of early satiety/H } & 20 & 1.19 & 0.21 & 49 & 0.56 & 0.12 & 米米 \\
\hline \multicolumn{2}{|c|}{ Faecal fat (grams/day) } & 32 & 11.5 & 1.3 & 119 & 18.5 & 1.6 & 米粉 \\
\hline \multicolumn{2}{|c|}{ Fat maldssimilation in $\%$} & 32 & 14.2 & 2.6 & 119 & 14.8 & 1.2 & $n \mathrm{si}^{2}$ \\
\hline \multicolumn{2}{|c|}{ Faecal mass (grams/day) } & 31 & 180 & 17 & 109 & 274 & 17 & 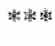 \\
\hline \multicolumn{2}{|c|}{ Bowel frequency per day } & 35 & 1.4 & 0.1 & 115 & 1.7 & 0.1 & 㽝 \\
\hline \multicolumn{2}{|c|}{ Frequency of } & $n$ & yes & $\%$ & n & yes & $\%$ & \\
\hline & early satiety & 38 & 29 & 76 & 125 & 63 & 50 & 粉 \\
\hline & meteorism & 20 & 9 & 45 & 46 & 36 & 78 & 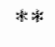 \\
\hline & vomiting & 38 & 10 & 26 & 125 & 9 & 7 & 将为 \\
\hline
\end{tabular}

Hange is from 0.000 to 3.000

* denotes $\mathrm{p}<0.05 ; *$ denotes $\mathrm{p}<0.01$; *** denotes $\mathrm{p}<0.001$ 


\section{Steatorhoea}

The significant differences in patients with normal faecal fat output to moderate steatorrhoea (faecal fat $<14$ grams/day) and severe steatorrhoea (faecal fat $\geq 14$ grams/day) are given in Table III.7. It was found that patients with higher faecal fat excretion had lost significantly more weight since health, whilst the difference in weight loss since operation was non-significant. Patients with severe steatorrhoea had a significantly higher incidence of oro-coecal transit shorter than 75 minutes and were admitted earlier after operation (Table III.7).

Table III.7 Differences in patients after total gastrectomy divided according to normal faecal fat output / moderate steatorrhoed and severe steatorrhoea

\begin{tabular}{|c|c|c|c|c|c|c|c|}
\hline & \multicolumn{3}{|c|}{ faccall fat $<14 \mathrm{~g} / \mathrm{d}$} & \multicolumn{3}{|c|}{ faecal fat $\geq 14 \mathrm{~g} / \mathrm{d}$} & \multirow[t]{2}{*}{ p } \\
\hline & n & mean & SEM & $\mathrm{n}$ & mean & SEM & \\
\hline Time pastis operation (days) & 87 & 706 & 140 & 73 & 384 & 54 & * \\
\hline Weight logs since health (BMA) & 88 & 2.03 & 0.23 & 75 & 2.94 & 0.28 & $*$ \\
\hline Ferritin $(\mu \mathrm{g} / \mathrm{l})$ & 83 & 66.4 & 10.8 & 77 & 125.8 & 24.1 & $*$ \\
\hline Alburnine $(g / 1)$ & 85 & 45.2 & 0.8 & 74. & 42.3 & 0.6 & $* *$ \\
\hline Chymotrypsin (U/1) & 30 & 7.3 & 1.0 & 34 & 3.5 & 0.3 & ** \\
\hline Frecal masss $(g / d)$ & 83 & 181 & 11 & 69 & 340 & 21 & 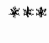 \\
\hline Faccal frem tuency (per day) & 83 & 1.49 & 0.10 & 76 & 1.80 & 0.12 & * \\
\hline Frecal consístency & 88 & 1.21 & 0.06 & 78 & 1.54 & 0.06 & *** \\
\hline \multirow[t]{2}{*}{ Rupid oro-coecall transith } & n & yes & w & n. & yes & $\%$ & \\
\hline & 85 & 12 & 14 & 72 & 22 & 31 & $*$ \\
\hline
\end{tabular}

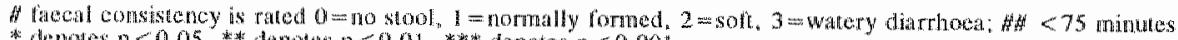

$*$ denotes $p<0.05$, * denotes $p<0.01$, * * wenotes $p<0.001$

\section{Body mass index}

In a univariate subgroup analysis of patients with normal weight (body mass index $\geq 20$ ) and patients with underweight on admission (body mass index $<20$ ) it was found that patients with a body mass index below 20 suffered significantly more often from symptoms $(p=0.02)$. A specific symptom, however, could not be indicated. Neither the weight development since health and since operation, the calorie intake during the controlled diet period, the types of operations (with or without continuous duodenal passage and/or pouch), the frequency of bacterial overgrowth and/or rapid upper intestinal transit, nor the degree of steatorrhoea were significantlly different in these two groups.

Patients who had lost much weight since operation $(\geq 9.5 \%$ of body mass index at operation) had been heavier during health and at operation, but lighter on admission, compared with patients with weight loss $<9.5 \%$. Calorie intake was 
similar, resulting in a significantly higher calorie intake per $\mathrm{kg}$ body weight in this group. The mean number of meals was lower in the group with greater weight loss (Table III.8).

Table III.8 Differences in patients after total gastrectomy divided according to the amount of weight loss since operation

\begin{tabular}{|c|c|c|c|c|c|c|c|}
\hline & \multicolumn{3}{|c|}{ weight loss $<9.5 \%$} & \multicolumn{3}{|c|}{ weight loss $\geq 9.5 \%$} & \multirow[t]{2}{*}{ p } \\
\hline & $n$ & mean & SEM & $\mathbf{n}$ & mean & SEM & \\
\hline BMI in health & 85 & 25.8 & 0,4 & 85 & 27.4 & 0.5 & 皮妆 \\
\hline BMI at operation & 86 & 22.2 & 0.4 & 86 & 26.2 & 0.4 & ***** \\
\hline BMI on admission & 86 & 22.6 & 0.4 & 86 & 21.5 & 0.3 & * \\
\hline \multicolumn{8}{|l|}{ Change in BMI between } \\
\hline health and operation & 85 & 3.6 & 0.3 & 85 & 1.3 & 0.2 & $* *$ \\
\hline health and admission & 85 & 3.2 & 0.3 & 85 & 5.9 & 0.3 & 瓷米 \\
\hline Number of meals/day & 82 & 5.9 & 0.2 & 85 & 5.4 & 0.1 & * \\
\hline Kcal/day & 79 & 2280 & 58 & 83 & 2300 & 46 & ns \\
\hline $\mathrm{Kcal} / \mathrm{kg}$ body weight/day & 78 & 35.8 & 1.1 & 76 & 39.2 & 1.0 & * \\
\hline
\end{tabular}

$*$ denotes $p<0.05, * *$ denotes $p<0.01,{ }^{* * *}$ denotes $p<0.001$

\section{Discussion}

In the future, the number of patients surviving gastric cancer can be expected to increase due to earlier diagnosis ${ }^{30.33}$, improved surgical techniques ${ }^{34.42}$, and adjuvant chemotherapy ${ }^{34}$. The problems arising after potentially curative total gastrectorny are therefore of great clinical importance.

Possible causative factors for malnutrition and weight loss after total gastrectomy are: tumour reccurence, anorexia ${ }^{1-4}$, rapid upper intestinal transit ${ }^{5}$, the type of operation $^{6-12}$, upper intestinal bacterial overgrowth ${ }^{5}$, lack of gastric lipase ${ }^{13}$, exocrine pancreatic insufficiency $y^{14-18}$ or pancreatico-cibal dyssynchrony ${ }^{19-25}$.

In our study group lower tumour stages were predominant and patients with recurrences and/or metastasis were excluded. The risk that unnoticed tumour recurrence influenced the evaluation is therefore very low.

The vast majority of the study patients complained of a variety of abdominal symptoms of which meteorism, dyspepsia, and early satiety were the most common and most severe. Although the overall symptomatic burden, estimated with the symptom score, was low, symptoms seemed to be a limiting factor with regards to 
the daily calorie intake.

The patients in our study group had lost weight before and after the potentially curative operation. Considering that underweight patients complained more often of abdominal symptoms and patients who had recently lost more weight consumed more kilocalories per $\mathrm{kg}$ body weight and day, one possible conclusion is that the patients troubled by the weight loss attempt in vain to overcome the phenomenon by eating more.

Some of the symptoms, e.g. dysphagia, have an easily identifiable cause: Oesophagitis was common in this study, as is reported by other authors ${ }^{43}$, and should be investigated at the least clinical suspicion. The frequency of oesophagitis reported by us may, however, be too high, as the patients with known endoscopic data had more reflux symptoms. This might be due to a selection bias from the endoscopic examination performed before admission. Treatment of postgastrectomy oesophagitis is difficult as the inflammation is per definition of the alkaline type.

The calorie intake of our patients during the period of controlled diet was supprisingly high, almost reaching the recommended value of 40 kilocalories $/ \mathrm{kg}$ body weight ${ }^{4}$. Though calorie intake at home probably had been lower, these results do not support the idea that the weight loss is mainly caused by low intake. On the contrary, patients suffering from greater weight loss seem to consume more calories per $\mathrm{kg}$ body weight as a (subconscious) reaction.

Looking at the biochemical values reflecting malabsorption we found anaemia to be frequent, but most of the time it was not severe. Iron deficiency was increasing with time after operation, but it was not until more than 800 days post-operatively that the majority of the patients had subnormal ferritin values.

The incidence and severity of fat malassimilation is high in patients after total gastrectomy, resulting in higher faecal mass and more frequent and softer stools. Weight loss since health was higher in the group with severe steatorrhoea and these patients also had been admitted sooner after surgery.

Using univariate analysis, neither the type of operation nor the prevalence of bacterial overgrowth of the upper intestine seemed to be of marked importance as pathophysiological mechanisms of steatorrhoea. The same is true of the exocrine pancreatic function: mean faecal chymotrypsin output was similar compared with nomal controls ${ }^{29}$. However, in a separate intervention study, the effect of large doses of pancreatic enzymes was compared with placebo treatment in patients with severe steatorrhoea. Enzyme supplementation resulted in an overall symptomatic improvement of the patients, a small but significant improvement of fat assimilation within the group of patients with moderate steatorrhoea $(<28 \mathrm{~g} /$ day $)$, and a lower caloric demand to maintain body weight ${ }^{45}$.

Considering the rather high prevalence of rapid oro-coecal transit in the study patients the hypothesis of pancreatico-cibal dyssynchrony as a main cause of fat 
malassimilation is supported by our results.

In conclusion, malassimilation after total gastrectomy does not have one single cause. Possible factors have to be analysed by means of multivariate techniques. Symptom-induced malnutrition and rapid upper intestinal transit, resulting in pancreatico-cibal dyssynchrony, seem to be major determinants. 


\section{References}

1. Adams JF. The clinical and metabolic consequences of total gastrectomy. I. Morbidity, weight, and nutrition. Scand J Gastroenterol 1967;2:137-149

2. Robers KE, Randall HT, Bane HN, Medwid A, Schwartz MK. Studies of thephysiology of the dumping syndrome. NY State J Med 1955,55:2897-2902

3. Delbrück H, Severin M, Lindenbeck U. Diäterische Aspekte und Befunde bei 227 gastrektomierten Magenkarzinompatienten. Akt Ernähr 1990;15:17-19

4. Sategna Guideti C. Bianco L. Malnutrition and malabsorption after total gastrectomy. A pathophysiologic approach. J Chin Gastroenterol 1989; 11/5:518-524

5. Armbrecht U, Lundell L, Lindstedt G, Stockbrügger RW. Causes of malabsorption after total gastrectomy with Roux-en-Y reconstruction. Acta Chir Scand $1988 ; 154: 37-41$

6. Fass J, Bares R, Staude M, Schumpelick V. Type of stomach replacement and intestinal motility after total gastrectomy. Leber Magen Darm 1993;23;194-203

7. Fass J, Bares R, Hermsdorf V, Schumpelick V. Intestinal motility after jejunum interposition and Roux- $Y$ construction - an animal experiment study. Langenbecks Arch Chir 1993;378:239-248

8. van der Mijle HC, Kleibeuker JH, Limburg AJ, Bleichrodt RP, Beekhuis H, van Schilfgaarde $\mathbb{R}$. Manometric and scintigraphic studies of the relation between motility disturbances in the Roux limb and the Roux-en-Y syndrome. Am J Surg $1993 ; 166: 11-17$

9. Woodward A, Sillin Lf, Bortoff A. Migrating myoelectric complex and jejunal slow-wave propagation after Roux-gastrectomy in dogs. Dig Dis Sci 1993;38:10731078

10. Takahashi T, Yamamura T, Yokohama E Kantoh M, Kusunoki M, Ishikawa Y.Utsunomiya I. Impaired contractilie motility of the gallbladder after gastrectomy. Am J Gastroenterol 1986:81:672-677

11. Miholic J, Meyer HD, Kotzerke J, Balks J, Aebert H, Jane J, Weimann A, Pichlmayr R. Emptying of the Gastric Substitute After Total Gastrectomy: Jejunal Interposition versus Roux-en-Y. Ann Surg 1989;210/2:165-172

12. Li Destri G. Trombatore G, La Greca G, Rinzivillo C, Rodolico M, Desiderio C. Orsina N, Di Cataldo A, Puleo S. Total gastrectomy: Nutritional status after different reconstruction techmiques. An experimental study. J Surg Oncol $1992 ; 49: 98-102$

13. Carriere F. Barrowman JA, Verger, Laugier R. Secretion and Contribution to Lipolysis of Gastric and Pancreatic Lipases During a Test Meal in Humans. Gastroenterology 1993:105:876-888

14. Früess H, Böhm J, Malfertheiner P, Glasbrenner B, Müller M, Hotbauer B, Riepl RL, Büchler MW. Exokrine Pankreasinsuffizienz nach Gastrektomie: Eine primäre Funktionsstörung. Chirurgische Gastoenterologie 1994;10:324-330

15. Gullo L, Costa L, Ventrucci M, Mattioli S, Vitti G, Labò G. Exocrine Pancreas Funktion after Total Gastrectomy. Scand J Gastroenterol 1979;14:401-407 
16. Köhler H, Schafmayer A, Peiper HJ. Die sekundäre exokrine Pankreasinsuffizienz nach Magenresektion. In: Kozuschek W, Paquet KJ eds. Pankreas Diagnostik, Theraple. Freiburg: S. Karger Gmbl 1992:547-554

17. Büchler $M$, Malfertheiner $P$, Glasbremer B, Friess $H$, Beger HO. Secondary Pancreatic Insufficiency Following Partial and Total Gastrectomy. Nutrition $1988: 4: 314-316$

18. Walther B, Clementson C, Vallgren S, Ihse I, Ảkesson B. Fat malabsorption in patients before and after total gastrectony, studied by the triolein breath test. Scand J Gastroenterol $1989: 24: 309-314$

19. Mackay C. Postgastrectomy steatorrhea. Am J Surg 1970;120:324-328

20. Curran FT, Hill GL. Failure of nutritional recovery after total gastrectony. $\mathrm{Br} J$ Surg 1990;77:1015-1017

21. Tabaqchali $S$. The Pathophysiological Role of Small Intestinal Bacterial Flora. Scand J Gastroenterol 1970;6:139-163

22. Armbrecht U, Lundell L, Stockbrügger RW. The benefit of pancreatic enzyme substitution after total gastrectomy. Aliment Pharmacol Therap 1988:2:493-500

23. Armbrecht U, Brägelmann R, Baumgart I, Stockbrügger RW. Fecal Chymotrypsin Output in Relation To Fecal Fat after Partial and Total Gastrectomy. Gastroenterology 1994: 106:A219

24. Worning $H$. The effect of enzyme substitution in patients with pancreatic insufficiency. Scand J Gastroenterol 1980;15:529-533

25. Tillander H, Tveit $\mathbb{E}$. Beeinflussung des Dumping-Syndroms mit Parkreon. Münch Med Wschr 1978;120:1717-1718

26. van de Kamer JH, ten Bokkel Huinink $H$, Weyers HA. Rapid method for the determination of fat in faeces. J Biol Chem 1949;177:347-355

27. Armbrecht; U, Jensen J, Eden S, Stockbrügger RW. Assessment of Oro-coecal Transit Time by Means of a Hydrogen $\left(\mathrm{H}_{2}\right)$ Breath Test As Compared with a Radiologic Control Method. Scand J Gastroenterol 1986;21:669-677

28. TNM Classification of Malignant Tumours, Hermanek P. Sobin L.H. eds, $4^{\text {th }}$ edition, $2^{\text {tal }}$ revision, Springer Verlag 1992:45-48

29. Stockbrügger RW, Armbrecht U. Determination of Faecal Chymotrypsin Concentration and 72- Hour Faecal Chymotrypsin Output in the Detection of Pancreatic Steatorrhea. Scand I Gastroenterol 199; 188:13-19

30. Sue-Ling HM, Johston D, Martin IG, Dixon MF, Lansdow MR, McMahon MJ, Axon AT. Gastric cancer: a curable disease in Britain. BMI 1993;307:591-596

31. Spataro V, Genoni M, Maurer C, Muller W. Stomach cancer: 10 years experiences with surgical treament and possibilities for mproving the prognosis. Helv Chir Acta 1993;59:589-595

32. Guadagni S, Reed PI, Johnston BJ, De-Bernardinis $G$, Catarci M, Valenti M, diOrioF, Carboni M. Early gastric cancer: follow-up after gastrectomy in 159 patients. Br J Sur 1993;80:325-328

33. Moureaux I, Bougaran d. Early gastric cancer. A 25-year surgical experience. Ann Surg 1993;217:347-355 
34. Meyer HJ, Jahne J, Wilke H. Perspectives of surgery and multimodality treatmeni in gastric carcinoma. I Cancer Res Clin Oncol 1993;119:384-394

35. Pacelli-F. Doglietto-GB, Bellatone-R, Alfieri-S, Sgadari-A, Crucitti-F. Extensive versus limiced lymph node dissection for gastric cancer: a comparative study of patients. Br J Surg 1993;80:1153-1156

36. Bonenkamp $J \mathbb{J}$, Van den Velde $\mathrm{CJ}$, Kampschoer $\mathrm{GH}$, Hermans $\mathbb{J}$, Hermanek $\mathrm{P}$, Bemelmans $M$, Gouma DJ, Sasako M Maruyama $K$. Comparison of faciors influencing the prognosis of Japanese, German, and Dutch gastric cancer patients. World J Surg. 1993; 17:410-414

37. Roder JD, Bottcher K, Siewert JR, Busch R, Hermanek P, Meyer HJ. Prognostic factors in gastric carcinoma. Result of the German Gastric Carcinoma Study. Cancer 1993; 72:2089-2097

38. Wanebo HJ, Kennedy Bj, Chmiel J, Steele B, Winchester D, Osleen R. Cancer of the stomach. A patientent care study by the American College of Surgeons. Ann Surg 1993;218:583-592

39. Junginger TH, Walgenbach S. Postgastrectomy Reconstruction By Esophagojejunostomy Roux-en-Y. Nutrition 1988;4:239-242

40. Meyer HJ, Jähne J, Wilke H, Pichlmayr R. Surgical Treatment of Gastric Cancer: Retrospective Survey of 1,704 Operated Cases With Special Reference to Total Gastrectomy as the Operation of Choice. Semin Surg Oncol 1991;7:356-364

41. McNeer G, Bowden L, Booher R, McPeak C. Elective Total Gastrectomy for Cancer of the Stomach: End Results. Ann Surg 1974;180/2:252-256

42. Menke H. Morbiditär und Letalität nach Operationen wegen Magenkarzinom. Ergebnisse einer prospektiven Untersuchung zur Bedeutung unterschiedlicher Risikofaktoren. Med Klin 1992;87:300-304

43. Domjan L, Simon L. Alkaline relux esophagitis in gastroresected patients. Objective detection with a simple isotope method. Scand J Gastroenterol Suppl. 1984:92:245249

44. Wechsler, JG. Ernährungsverhalten und Diät nach Gastrektomie. In: Der gastrektomierte Patient. Armbrecht U, Stockbrügger RW eds. Freiburg, S. Karger GmbH 1992:79-87

45. Brägelmann R, Armbrecht U, Rosemeyer D, Schneider B, Zilly W, Stockbrügger RW. The Effect of Pancreatic Enzyme Supplementation in Patients with Total Gastrectomy and Steatorrhea. Gastroenterology 1995;108/4:A451 


\section{Chapter IV}

Total Gastrectomy: The Influence of Preserved Duodenal Transit and of Pouch Reconstruction on Abdominal Symptoms, Nutrient Assimilation, and Medico-Social Functioning

R Brägelmann, U Armbrecht, D Rosemeyer, B Schneider, W Zilly, RW Stockbrügger

Accepted for publication in the Italian Journal of Gastroenterology 


\section{Abstract}

\section{Background/Aims}

The aim of this retrospective study was to elucidate whether patients with different reconstruction after total gastrectomy (duodenal bypass without pouch (subgroup la, $\mathrm{n}=88$ ); duodenal bypass with pouch (subgroup $\mathrm{Ib}, \mathrm{n}=27$ ); continuous duodenal transit (subgroup II, $n=27)$ ) differ concerning abdominal symptoms, nutrient assimilation, and medico-social functioning.

\section{Methods}

The 142 patients $(f=49, m=93$; mean age 57.2 years, $(95 \%$ confidence interval 55 to 59)) after potentially curative total gastrectomy for gastric malignancy 500 days earlier (mean; $95 \%$ confidence interval 334 to 666) were evaluated for abdominal symptoms, biochemical and haematological parameters, endoscopic findings, small intestinal bacterial overgrowth, oro-coecal transit time, objective signs of malassimilation, and the degree of medico-sociall functioning.

\section{Results}

There were no significant differences between the subgroups in any of the examined parameters.

\section{Conclusion}

In this study, neither subjective nor objective patient data support preference for any single mode of the examined reconstructions after total gastrectomy. However, small patient numbers, unstandardised reconstruction procedures and a recruitment bias might. influence these findings. 


\section{Introduction}

Since the first successful total gastrectomy in 1897 by Schlatter more than 50 different surgical approaches and types of reconstruction have been proposed for this operation. This has caused a continuous discussion about the best procedure to minimise postoperative abdominal symptoms and malassimilation!

Functionally, the different types of operations can be divided into procedures which preserve a continuous duodenal transit and procedures with a duodenal bypass, both alternatives either with or without a construction of a reservoir as a stomach substitute.

Some authors have found patients with preserved duodenal transit to perform better compared with patients with duodenal bypass ${ }^{2-6}$, pointing to disturbed intestinal motility ${ }^{7.9}$, changed release of hormones and of regulatory peptides ${ }^{5,10}$ and primary or secondary exocrine pancreatic insufficiency ${ }^{9,11-17}$ after the bypass operation. Evaluation of exocrine pancreatic function after total gastrectomy, however, is very problematic $^{18}$. Some authors could not demonstrate any benefit of the continuous duodenal transit ${ }^{19}$. Authors favouring pouch-constructions underline the necessity of a reservoir for an adequate digestive function ${ }^{20.32}$, while others could not demonstrate any benefit of the pouch construction ${ }^{33-36}$.

The aim of the study was to elucidate whether after total gastrectomy patients with duodenal bypass without pouch-construction, or with duodenal bypass with pouchconstruction, or with preserved continuous duodenal transit differ in symptoms, nutrient assimilation, and medico-social functioning. Other aspects of these data have been evaluated on different occasions ${ }^{9,37}$.

\section{Patients and methods}

During the period from May 1990 to January 1993, 196 consecutively admitted patients following a potentially curative total gastrectomy for gastric malignancy were investigated according to a standardised protocol at three German gastroenterological rehabilitation hospitals in Bad Kissingen $(n=95)$, Bad Driburg $(\mathrm{n}=79)$, and Bad Brückenau ( $\mathrm{n}=22)$. In Germany patients after major surgery have the opportunity of a post-operative admission to a rehabilitative centre. These patients, therefore, were electively admitted for rehabilitative purposes and had no acute or severe disease. Of the 196 patients, 14 were evaluated for the second time, and in eight patients a recurrence and/or metastasis was diagnosed shortly after admission. In eleven patients it could not exactly be established whether they had continuous duodenal transit or not. In 21 patients it was unknown whether they had a pouch construction. These 54 patients were not included in this study. The remaining 142 patients were evaluated (Bad Kissingen $n=77$, Bad Driburg $n=52$, 
and Bad Brückenau $n=13$ ). They were 49 females and 93 males with a mean age of 57.2 years $(95 \%$ confidence interval 55.4 to 59.0 ) after potentially curative total gastrectomy for gastric malignancy 500 days earlier (mean; $95 \%$ confidence interval 334 to 666 ). Three groups were compared: patients with duodenal bypass without pouch (subgroup la, $\mathrm{n}=88$ ), patients with duodenal bypass and pouch (subgroup $\mathrm{Ib}, \mathrm{n}=27$ ), and patients with continuous duodenal transit without pouch (subgroup II, $\mathrm{n}=27$ ).

\section{Study Design}

After clinical and biochemical evaluation on admission, all patients were put on a standardised diet for a period of five days during which symptoms, bowel habits, energy intake and fat assimilation were evaluated. Thereafter, a $\mathrm{H}_{2}$-breath test with radiopaque markers and an oesophago-intestinal endoscopy were performed. Symptoms were recorded in two different ways: 1) When admitted to the hospital patients were asked by the investigators whether they suffered from the following abdominal symptoms: dyspepsia, meteorism, early satiety, reflux, dysphagia, dumping, vomiting; also overall well-being was evaluated. 2) Additionally, meteorism, early satiety, dyspepsia, nausea, dumping, dysphagia, and vomiting were scored daily in all patients according to a questionnaire during the period of controlled diet and the sum of a five-day-score was reported. In one centre (Marbachtalklinik) the specific scores for the abdominal complaints were noted in 66 patients (11 missing values). Faecal frequency and faecal consistency were scored in a similar way for all patients. Patients who were on pancreatic enzyme supplementation at the time of hospital admission had been asked to discontinue this. During the diet period, meals were composed of $48 \%$ fat, $17 \%$ protein, and $35 \%$ carbohydrates respectively, and were not limited quantitatively. However, individual nutritional intake was quantified at every meal by an attending dietician and summarised each day. Faecal fat output was assessed during the last three days of the controlled diet period according to the method of van de Kamer ${ }^{38}$.

Using a standardised breakfast with ten radiopaque plastic markers added to it according to Armbrecht et $\mathrm{al}^{3{ }^{34}}$, the frequency of a shortened oro-coecal transit time was diagnosed radiographically, when the first markers had passed into the colon at 75 minutes. Upper intestinal bacterial overgrowth was evaluated by an $\mathrm{H}_{2}$ breath test in combination with a second radiograph which was taken when a $100 \%$ rise above baseline values occurred in $\mathrm{H}_{2}$-concentration in breath.

An upper endoscopy was performed in each patient, except when it had been done during the previous two months. In these cases the endoscopic diagnosis from the last examination was recorded. Body mass was evaluated using the Quetelet index (weight/height ${ }^{2}$; normal range 20.0 to $25.0 \mathrm{Kg} / \mathrm{m}^{2}$ ).

In order to assess medico-social dysfunction the Edinburgh Rehabilitation Status Scale (ERSS) was applied to all patients on admission by one of the authors, and 
the employment status was noted. The ERSS scale ranges from 0 to 28 points, with higher points indicating a poorer medico-social functioning. The scale measures the dimensions of medico-social performance in four different subscales: independence, activity, social integration, and effects of symptoms on lifestyle. The Edinburgh Rehabilitation Status Scale has been tested in several somatic patient groups in rehabilitative medicine ${ }^{40}$. In one centre (Marbachtalklinik; $n=77$ ) the ERSSsubscores were analysed.

Statistical calculations included the $x^{2}$ - test and ANOVA-models using a Bonferroni correction for three-group-comparisons with a p-value of 0.017 indicating significancet ${ }^{41}$. The protocol was approved by the ethical committee of the Bayerische Landesärztekammer, Germany.

\section{Results}

\section{Patient characteristics}

Gender, age, time since operation, tumour stage, and type of operation are given in Table IV.1 and Table IV.2.

Table IV.1 Gender, age, time since operation, and tumour stage in 142 patients with different reconstruction after total gastrectomy

\begin{tabular}{lccc}
\hline \multicolumn{3}{c}{ duodenal bypass } & jejunal interposition \\
& withour pouch & with pouch & \\
Gender & 31 & 9 & 9 \\
Female & 57 & 18 & 18 \\
Male & $58(57-60)$ & $57(55-63)$ & $53(49-57)$ \\
Age (years)* & $573(318-829)$ & $37(221-519)$ & $395(144-646)$ \\
Time past operation** & & 0 & \\
Tumour stage (UICC) & 3 & & 0 \\
O & 26 & 1 & 11 \\
IA & 21 & 3 & 5 \\
IB & 15 & 5 & 0 \\
II & 10 & 2 & 6 \\
IIIA & 3 & 5 & 2 \\
IIIB & 2 & 3 & 1 \\
IV & 8 & 1 & 2 \\
Lymphomas & & 7 & \\
\hline
\end{tabular}

* means and $95 \%$ confidence intervals; ** in days 
Table IV.2 Type of operation in 142 patients with different reconstruction after total gastrectomy

duodenal bypass

jejunal interposition

without pouch with pouch

Type of operation

Rolix-en-Y

80

8

Rodino

0

2

Omegaloop

2.

0

schloffer

1

0

Siewert-peiper

0

3

Kremer

0

2

Graham

0

1

Oesophagojejunostomy*

5

11

Jejunal interposition 27

* not further specified

\section{Biochemistry}

Laboratory tests are given in Table IV.3. Patients with continuous duodenal transit had a higher faecal chymotrypsin concentration and output than patients with duodenal bypass. However, these differences were not significant.

Table IV.3 Haenatological and biochemical data on hospital admission in 142 patients with different reconstruction after total gastrectomy

\begin{tabular}{|c|c|c|c|c|c|c|c|c|c|}
\hline & \multicolumn{6}{|c|}{ duodenal bypass $(n=115)$} & \multicolumn{3}{|c|}{ jejunal interpesition $(n=27)$} \\
\hline & \multicolumn{3}{|c|}{ witllow promeh $(\mathrm{n}=8 \mathrm{~S})$} & \multicolumn{3}{|c|}{ with pouch $(n=27)$} & \multirow[b]{2}{*}{$\mathrm{n}$} & \multirow[b]{2}{*}{$\mathbf{m}$} & \multirow[b]{2}{*}{$\mathrm{Cr}$} \\
\hline & $\mathrm{n}$ & m & $\mathrm{CH}$ & $n$ & m & $\mathrm{Cl}$ & & & \\
\hline Hacmoglobim (m) & 86 & 83.1 & $80.6-84.9$ & 27 & 85.6 & $80.6-90.5$ & 27 & 被1.8 & $78.1 \times 85.6$ \\
\hline Ferrilin $(\mu g / L)$ & 83 & 91 & 67116 & 27 & 159 & $29-288$ & 26 & 83 & $43-123$ \\
\hline Albumin $(\mathrm{g} / \mathrm{L})$ & 41 & 43.3 & $41.8-44.7$ & 27 & 43.4 & 41.456 & 27 & 42.0 & $38.6-45.4$ \\
\hline Culdeian (mmoll/L) & $\mathrm{SO}_{0}$ & 2.1 & $2.35-2.47$ & 27 & 2.33 & $2.28-2.39$ & 27 & 2,46 & $2.37-2.56$ \\
\hline Chymotryph in* (W/g) & 38 & 4.1 & 3.4 .4 .9 & 10 & 6.6 & $2.9 \cdot 10.3$ & 13 & 7,3 & $2.9 \times 11.7$ \\
\hline Chy-outgui (U/7an) & 37 & 2790 & $2200-3390$ & 9 & 3117 & 2121.4113 & 13 & 4521 & $2244-6798$ \\
\hline
\end{tabular}

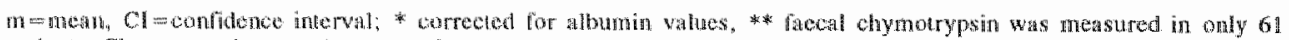
puthenis: Chy-bitput denoles chymotrypin ouput.

\section{Endascopy}

Forty-nine of the 75 patients undergoing endoscopy $(65 \%)$ showed a normal postoperative appearance. Twenty-seven percent had an oesophagitis, and three 
patients $(4 \%)$ had food retention proximal to the anastomosis. Three other patients had a stenosis of the anastomosis. There was no significant difference between the study groups regarding endoscopic findlings (Table NV.4).

Table IV.4 Endoscopic findings on admission in 75 patients with different reconstruction after total gastrectomy

\begin{tabular}{|c|c|c|c|c|c|c|c|}
\hline & & \multicolumn{4}{|c|}{ duodenal bypass } & \multicolumn{2}{|c|}{ jejunal interpostition } \\
\hline & & \multicolumn{2}{|c|}{ without pouch } & \multicolumn{2}{|c|}{ with pouch } & \multirow[b]{2}{*}{$\mathrm{n}$} & \multirow[b]{2}{*}{ W } \\
\hline & & n & $\%$ & n & $\%$ & & \\
\hline \multicolumn{2}{|c|}{ Endoscopy performed } & $45 / 88$ & 51 & $17 / 27$ & 63 & $13 / 27$ & 48 \\
\hline \multirow[t]{4}{*}{ Diagnosis } & normal & 31 & 69 & 7 & 41 & 11 & 85 \\
\hline & oesophagitis & 9 & 20 & 9 & 53 & 2 & 15 \\
\hline & retention & 2 & 4 & 1 & 6 & 0 & 0 \\
\hline & stenosis & 3 & 7 & 0 & 0 & 0 & 0 \\
\hline
\end{tabular}

\section{Bacterial overgrowth and oro-coecal transit time}

The $\mathrm{H}_{2}$-breath test concerning bacterial overgrowth was unreliable in 31 patients, as they had raised $\mathrm{H}_{2}$-values in combination with rapid oro-coecal transit time. Three patients were $\mathrm{H}_{2}$-non-producers, and in six patients the test was unreliable because of technical reasons. The assessment of oro-coecal transit time was unreliable in six patients because of technical reasons (Table IV.5).

Table IV.5 Frequency of small bowel bacterial overgrowth (SBBO) and rapid oro-coecal transit ( $<75$ minutes, $\mathrm{ROCT}$ ) according to the $\mathrm{H}_{2}$-breath test with radiopaque markers in 142 patients with different reconstruction after total gastrectomy

\begin{tabular}{|c|c|c|c|c|c|c|c|}
\hline & & \multicolumn{4}{|c|}{ duodenal bypass } & \multicolumn{2}{|c|}{ jejunall interposition } \\
\hline & & \multicolumn{2}{|c|}{ without pouch } & \multicolumn{2}{|c|}{ with pouch } & \multirow[b]{2}{*}{$\mathrm{n}$} & \multirow[b]{2}{*}{$\%$} \\
\hline & & $\mathbf{n}$ & $\%^{\mathrm{a}}$ & $n$ & $\%$ & & \\
\hline \multirow[t]{3}{*}{$\mathrm{SBBO}$} & unreliable & $28^{*}$ & & $4^{* *}$ & & $8^{* * 4+4}$ & \\
\hline & yes & 21 & 35 & 10 & 42 & 10 & 53 \\
\hline & no & 39 & 65 & 13 & 58 & 9 & 47 \\
\hline \multirow[t]{3}{*}{ ROCT } & unrebliable & 4 & & 1 & & 1 & \\
\hline & yes & 22 & 26 & 2 & 8 & 7 & 27 \\
\hline & no & 62 & 74 & 24 & 92 & 19 & 73 \\
\hline
\end{tabular}

a denotes percentages of evaluable patients; "denotes 22 patients with fast iransit. $2 \mathrm{H}_{2}$-nonproducers, and 4 with technical problems; ${ }^{*}$ denotes 2 patients with fast transit, $1 \mathrm{H}_{2}$-nonproducer. and 1 with technical problems; $*$ denotes 7 patients with fast ransit and I with technical problems 
There were no significant differences regarding the frequency of small bowel bacterial overgrowth between the study groups. Patients with a pouch reconstruction had less often a shortened oro-coecal transit time than patients without, but this difference was not significant.

\section{Symptoms}

The study groups were similar concerning the frequency of abdominal symptoms. Meteorism, dyspepsia and early satiety were the symptoms mentioned most often (Table IV.6).

During the controlled diet period there were no significant differences in frequency and severity of total symptom score or of the specific abdominal symptoms between the study groups. The total symptom score was non-significantly lower in the patients with a pouch-construction (subgroup Ib) compared with those without (subgroup Ia and II; $p=0.07$ ) (Figure IV.1). The specific symptoms scores that were recorded in a subgroup of patients were not different either (Figure IV.2).

Table IV.6 Endoscopic findings on admission in 75 patients with different reconstruction after totall gastrectomy

\begin{tabular}{|c|c|c|c|c|c|c|}
\hline & \multicolumn{4}{|c|}{ Wuodenal bypass } & \multicolumn{2}{|c|}{ jejunal interposition } \\
\hline & \multicolumn{2}{|c|}{ without pouch } & \multicolumn{2}{|c|}{ with pouch } & \multirow[b]{2}{*}{$\mathbf{n}$} & \multirow[b]{2}{*}{$\%$} \\
\hline & $\mathbf{n}$ & $\%$ & $\mathbf{n}$ & $\%$ & & \\
\hline Dyspepsia & 61 & 69 & 18 & 67 & 18 & 67 \\
\hline Early satiety & 46 & 52 & 12 & 44 & 20 & 74 \\
\hline Reflux & 24 & 27 & 6 & 22 & 109 & 33 \\
\hline Dysplatgia & 18 & 20 & 6 & 22 & 93 & 11 \\
\hline Vomiting & 12 & 14 & 5 & 19 & 2 & 7 \\
\hline Metemrism* & $28 / 44$ & 64 & $12 / 17$ & 71 & $6 / 8$ & 75 \\
\hline Any symptom & 79 & 90 & 20 & 74 & 25 & 93 \\
\hline
\end{tabular}

" meteorism was only asked in 69 patients 


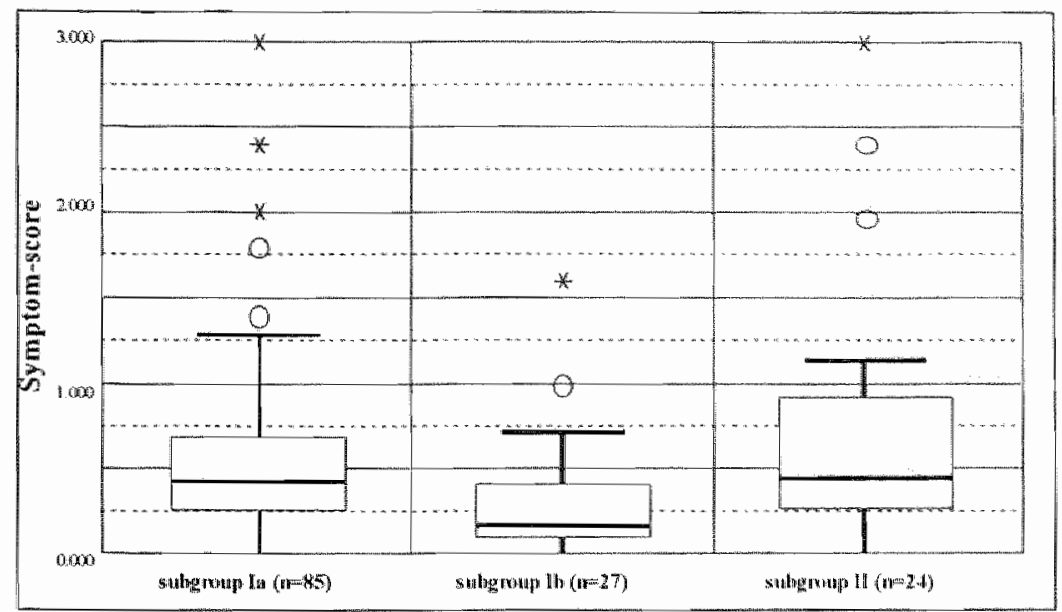

Figure IV.1 Total symptom score in subgroup la (duodenal bypass without pouch), subgroup Ib (duodenal bypass with pouch), and subgroup II (continuous duodenal transit) given in whisker-boxplots. The lower boundary of the boxes is the $25^{\text {th }}$ percentile, the upper boundary is the $75^{\text {tb }}$ percentile, the line in the box represents the median. The circles denote outliers, which are defined as cases with a value 1.5 to 3 box lenghts from de edge of the box. Cases mote that 3 box-lengths from the upper or lower end of the box are designated with a asterix. The whiskers show the highesi and lowest values that are not oulliers. The scale is from 0.000 to 3.000 . There were three missing values in subgroup la, and three missing values in subgroup II.

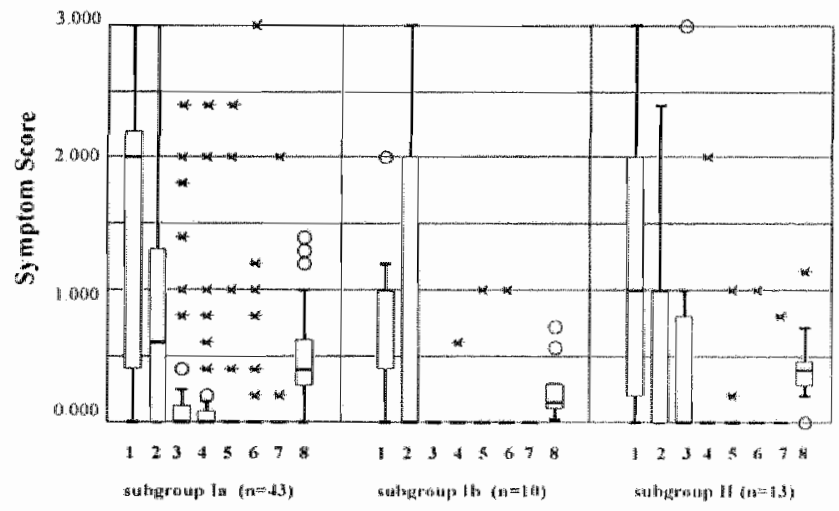

Figure IV.2 Total symptom score and specific symptom scores in subgroup la cduodenal bypass without pouch), subgroup Ib (duodenal bypass with pouch), and subgroup if (continuous duodenal transit) given in whisker-boxplots. (For explanation of the boxplots see figure (V.1). I=meteorism, $2=$ early satiety, $3=$ dyspepsin, $4=$ natsed, $5=$ dumping, $6=$ dysphagid, $7=$ vomiting, $8=$ total symptom scone. Symptoms arte ranked: $0=$ no, $1=$ light, 2 =moderate, $3=$ severe. The scalle is from 0.000 to 3.000 . in some cases the $75^{\text {th }}$ percentile was zeto. 


\section{Body mass and energy intake}

On admission the mean body mass index of all patients was $22.2 \mathrm{~kg} / \mathrm{m}^{2} 195 \%$ confidence interval 21.6 to 22.7 ) and mean weight loss since operation was $6.5 \%$ (95\% confidence interval 4.4 to 8.5). Mean energy intake was 155 kilojoules per kilogram body weight per day (95\% confidence interval 148 to 162) and the number of meals 5.7 (95\% confidence interval 5.4 to 5.8 ). Neither the continuous duodenal transit nor the presence of a pouch-construction after duodenal bypass was of significant influence on any of these parameters (Table IV.7).

Thable IV.7 Weight development and energy intake in 142 patients with different reconstruction after total gastrectomy

\begin{tabular}{lccc}
\hline & \multicolumn{2}{c}{ duodenal bypass } & jejunall interposition \\
& without pouch & with pouch & \\
\hline number & 88 & 27 & 27 \\
BMI $\left(\mathrm{kg} / \mathrm{m}^{2}\right)$ & $21.9(21.3-22.5)$ & $22.8(21.6-24.7)$ & $22.2(20.9-23.5)$ \\
number & 88 & 27 & 27 \\
Weight los: & $5.7(2.8-8.6)$ & $5.5(1.1-9.9)$ & $9.9(6.1-13.7)$ \\
number & 80 & 25 & 22 \\
Eunergy intake** & $156(1.47-165)$ & $158(137-179)$ & $148(136-160)$ \\
\hline
\end{tabular}

means and $95 \%$ confidence intervals; BMI denotes body mass index on admission; * weight loss in \% since operation; * kilojoule intake in $\mathrm{kJ} / \mathrm{kg}$ body weight and day of a 5 -day-period

\section{Bowel habits and steatorrhoea}

In the total patient population faecal consistency was reported to be normal to soft with a mean daily faecal frequency of 1.6 (95\% confidence interval 1.4 to 1.7 ). Mean faecal mass was 247 grams/day (95\% confidence interval 221 to 273). Mean faecal fat output was $16.5 \mathrm{grams} /$ day $(95 \%$ confidence interval 13.9 to 19.1) accounting for a mean fat malassimilation of $14.4 \%$ (95\% confidence interval 12.2 to 16.6 ), the median of which was $11.7 \%$. There were no significant differences between the three subgroups concerning faecal consistency, faecal frequency, faecal mass, faecal fat output and fat malassimilation (Table IV.8).

\section{Medico-social functioning}

On admission, there were no significant differences between the subgroups regarding the sum ERSS-score (Figure IV.3). The mean score of all patients $(n=141)$ was $4.4(95 \%$ contidence interval 3.8 to 4.9$)$, which shows a high degree of medico-social functioning. In the subgroup of patients with analysis of the ERSS-subscores the mean sum score was $5.4(95 \%$ confidence interval 4.5 to 6.3 ). 
"Inactivity" and "symptom induced lifestyle changes" scored highest.

Table IV.8 Bowel habits, faecal mass, faecal fat output and fat malassimilation in 142 patients with different reconstruction after total gastrectomy

\section{duodenal bypass jejunalinterposition}

without pouch with pouch

\begin{tabular}{lcccc}
\hline Faecal consistency* & $\mathrm{n}=$ & 88 & 27 & 27 \\
(per day; 5 days) & & $1.3(1.2-1.4)$ & $1.3(1.1-1.5)$ & $1.2(0.9-1.5)$ \\
Faecal frequency & $\mathrm{n}=$ & 85 & 25 & 23 \\
(per day; 5 days) & & $1.6(1.4-1.8)$ & $1.6(1.3-1.9)$ & $1.5(1.2-1.9)$ \\
Faecal mass & $\mathrm{n}=* *$ & 81 & 24 & 27 \\
(g/d; 3 days) & & $249(221-277)$ & $258(167-350)$ & $231(167-296)$ \\
Faecal fat output & $\mathrm{n}=$ & 85 & 25 & 27 \\
(g/d; 3 days) & & $18.3(14.5-22.0)$ & $14.1(9.9-18.4)$ & $13.0(8.7-17.3)$ \\
Fat malassimilation & $\mathrm{n}=$ & 82 & 25 & 24 \\
$(\% ; 3$ days) & & $16.0(12.9-19.1)$ & $11.5(8.3-14.7)$ & $11.9(7.7-16.0)$ \\
\hline
\end{tabular}

* faecal consistency is ranked: $0=$ no taeces, $1=$ normally formed, $2=$ soft, $3=$ watery diarrhoea; scale from 0.0 to 3.0 ; ** one centre (Hartwaldklinik) reported no faecal mass; given are the means and $95 \%$ confidence intervals

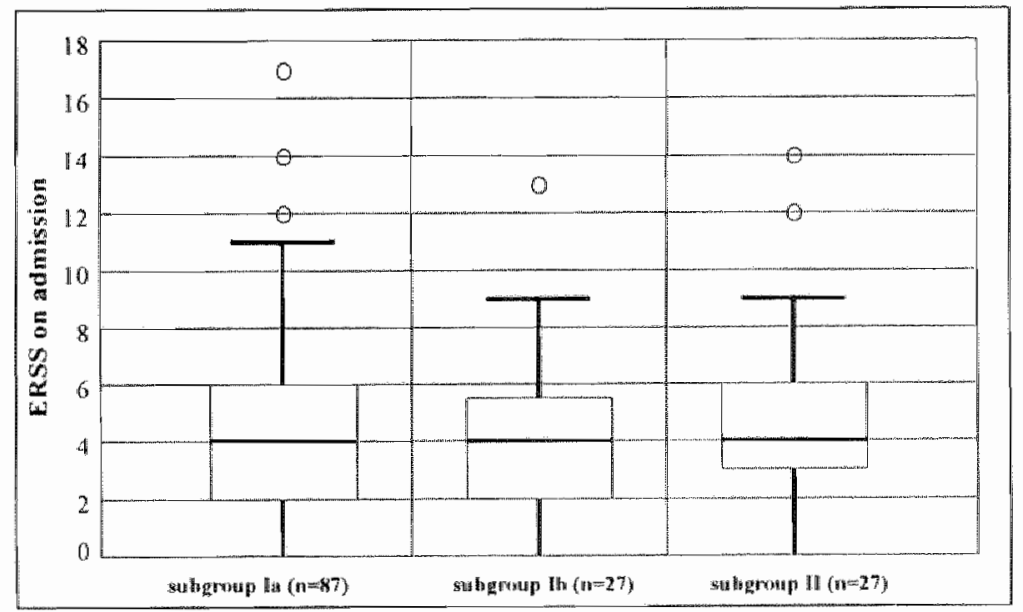

Figure IV.3 Edinburgh Rehabilitation Status Scale on admission in subgroup la (duodenal bypass without pouch), subgroup It) (duodenal bypass with pouch), and subgroup II (continuous duodenal transit) given in whisker-boxplots. (For explanation of the boxplots see figure IV. 1) The range of the summarising score is 0 to 28 with higher numbers indicating greater severity of dysfunction. There was one missing value in subgroup la. 
There were no significant differences between the study groups regarding the ERSS-subscores (Figure IV.4). Of those patients, who had been in active working life before operation, $52 \%$ of the patients with duodenal bypass without pouch, $54 \%$ of the patients with duodenal bypass with pouch, and $64 \%$ of the patients with continuous duodenal transit were temporarily not working or were in early retirement due to ill health; these differences were not significant.

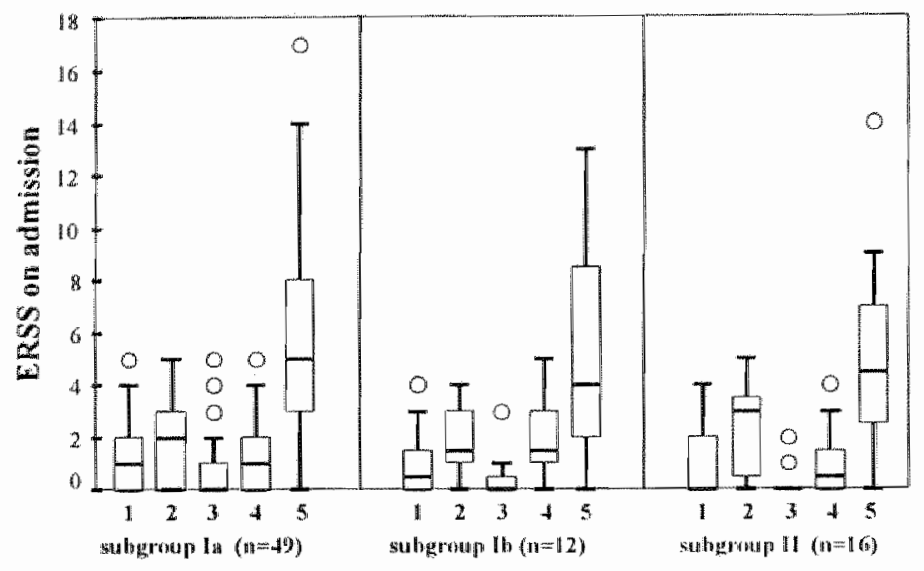

Figure IV.4 Edinburgh Rehabilitation Starus Scale and subscales on admission in subgroup la (duodenal bypass without pouch), subgroup to (duodenal bypass with pouch), and subgroup 11 (continuous duodenal transit) given in whisker boxplots. (For explanation of the boxplots see Figure IV. 1) Shown are the subscalles and the total scalle. 1 =independence/dependence, $\quad 2$ =activity/inactivity,$\quad 3=$ social integration/isolation, $4=e$ ffects of symptoms on lifestyle, 5=sum score. Each subscale has a range of zero to seven points with higher numbers indicating greater severity of dystunction. The range of the summarising score is 0 iro 28 . In sone cases the $75^{\text {th }}$ percentile was zero.

\section{Discussion}

During the last century surgeons have tried to optimise procedures of total gastric resection and post-operative reconstruction in order to minimise post-operative complaints, weight loss, and to ensure the highest possible quality of life.

Preservation of continuous duodenal transit should theoretically maintain normal entero-hormonal synergism better, and exocrine pancreatic function should change less compared with reconstruction based on a duodenal bypass. ${ }^{4-10.12}$. Furthermore, a higher degree of motility disturbances has been described in patients with duodenal bypass operations , $^{2,3.5}$.

The pouch-reconstruction was introduced to supply a gastric substitute. It was 
expected that patients could eat larger volumes at a meal, that the oro-coecal transit time would be longer, and that the pouch-construction would serve as a barrier against entero-oesophageal reflux ${ }^{20.32}$. However, preserving the duodenal transit or performing a duodenal bypass operation with construction of a pouch increases operating time. Preserving the duodenal transit also adds one intestinal anastomosis and is not always applicable because of anatomical considerations ${ }^{20}$.

The data regarding the benefit of a pouch-construction after total gastrectomy are not conclusive. There are a number of prospective randomised studies comparing total gastrectomy with pouch-constructions with procedures without pouch. Troid! et al ${ }^{20}$ reported a better weight development and appetite in patients with pouchconstruction. However, the energy intake of the patients was not quantified and the great difference in survival time might point to problems with comparability between the groups. Nakane et al. ${ }^{21}$ found a higher food intake and less weight loss in patients with pouch. However, patients for the trial were selected following unknown criteria, so that a patient bias is possible. Food intake was only anamnestically evaluated, the number of patients per group was very small, and the authors did not use a correction for three-group-comparison in the statistics. Applying such a correction to the data eliminates some of the reported differences. Schwarz et al. ${ }^{22}$ compared patients with duodenal preservation and pouches of two different sizes, Rodino-construction with pouches of two different sizes, and an ordinary Roux-en-Y construction (five groups with twelve patients each) and found a better quality of life in the first group. Stier et al. ${ }^{23}$ assessed 18 patients with interpositions with pouch and 18 patients with an Roux-en-Y construction without pouch. Patients with pouch-construction (and interposition) judged their own situation better on a symptom score. The study of Schmitz et al. ${ }^{24}$, who evaluated patients with an interposition and patients with an interposition with pouch, illustrates a major problem of prospective studies, because only 39 of the 74 patients fulfilled the criteria for the trial. Schlag et al. conclude that a pouchconstruction is of use, but this study has many methodological problems ${ }^{25}$. Additionally there are retrospective studies ${ }^{26.30}$ showing benefit for a pouchconstruction. However, in a prospective study by Liedman et al. ${ }^{3.3}$ on 89 patients, the patients with pouch had more postprandial problems than those without pouch and no benefit. De Almeida et al. had similar results in a retrospective study ${ }^{34}$. Furthermore, there are some experimental studies showing no benefit of a pouchconstruction compared to a construction without pouch ${ }^{35.36}$

In this survey in three gastroenterological rehabilitation centres we evaluated a large group of patients with different types of reconstruction after potentially curative total gastrectomy for gastric malignancy. The patients had in general been operated on for early stage tumour. In this group of patients a gastric reconstruction was regarded useful despite the surgical difficulties. The selection of the patients to a rehabilitation centre made sure that there was no current morbidity 
due to the post-operative situation, and excluded cancer recurrence in most of the cases.

A randomised prospective study with few centres entering patients would have ensured a homogenous group regarding the surgical procedures. Due to the selection procedure of the patients to a rehabilitation centre, surgical parameters and modifications were not standardised and cannot be given in detail as many different centres were admitting patients. Although this creates a certain heterogeneity of the patients, it also has positive aspects. Specialised surgical centres will not necessarily perform all different types of surgical reconstructions with the same skill. This would make randomisation procedures problematic. The surgical parameters in our patients vary independently and, therefore, they constitute an averaged group of patients after total gastrectomy performed in different hospitals.

A further problem might be a possible recruitment bias, as patients performing very well and patients performing very badly might not have applied for rehabilitation. As patients after total gastrectomy in Germany have the right for an admission to the rehabilitation centres irrespectively of their performing status the risk of bias does not seem to be very large.

The present comparison of three types of surgical reconstruction after total gastrectomy includes sufficient numbers of patients and used a uniform investigation of subjective symptoms and objective findings. In spite of this approach, no clinically significant differences could be found between the operation types.

Abdominal symptoms were common in all study groups and of similar frequency and intensity. Meteorism, dyspepsia, and early satiety were the complaints mentioned most often and causing the greatest discomfort. The overall symptom intensity, though, was low. This is possibly due to the above-mentioned selection.

After total gastrectomy, oesophagitis is frequent. In contrast to the results of other authors $^{20,21}$ our patients with pouch-constructions had non-significantly more often oesophagitis than patients without pouch and patients with continuous duodenal transit. This might be due to the stasis of the bowel fluids in the pouch. ${ }^{6}$. The frequency of a shortened oro-coecal transit time tended to be lower in patients with pouch than in those without, but also this difference was not significant.

Looking at exocrine pancreatic function, there was a higher faecal chymotrypsin output in patients with continuous duodenal transit compared with patients with duodenal bypass, but this was statistically not significant. Correspondingly, other authors could not find any differences in body weight and quality of life in patients with an jejunal interposition and patients with a Roux-en-Y operation both with pouch $^{19}$.

We did not find any significant difference in parameters concerning post-operative weight development, dietary habits, and energy intake. This is in agreement with 
the similarity of the three study groups concerning bowel habits and signs of malassimilation.

The Edinburgh Rehabilitation Status Scale has so far not been applied to patients with malignant disease. However, it seems applicable to use for comparison of our patients, since they were free of recurrence and/or metastasis, and the point of interest was the post-operative situation and its influence on medical and social functioning. All study groups had a high degree of medico-social functioning according to the ERSS compared to other patient groups in the literature ${ }^{40}$. It was not expected that medico-social function parameters would be affected by the type of operation, as we could not find any differences between the study groups regarding the principal somatic parameters.

In conclusion, in this large study of randomly-allotted cases neither subjective nor objective data support preference for any single mode of reconstruction after total gastrectomy for gastric cancer. 


\section{References}

1. Tittel A, Schumpelick $V$. History of Gastric Replacement. Hepato-gastroenterol $1989.36: 57-62$

2. Fass J, Bares $R$, Staude $M$, Schumpelick V. Type of stomach replacement and intestinal motility after total gastrectomy. Leber Magen Darm 1993;194:197-203

3. Miholic J, Meyer HD, Kotzerke J, Balks $J$, Aebert $H$, Jäne $J$, Weimann $A$, Pichlmayr R. Emptying of the Gastric Substitute After Total Gastrectomy: Jejunal Interposition versus RoulX-en-Y. Ann Surg 1989;210:165-172

4. Miholic J, Meyer HJ, Muller MJ, Weimann A, Pichlmayr R. Nutritional consequences of total gastrectomy: The relationship between mode of reconstruction, postprandial symptoms, and body composition. Surgery $1990 ; 108: 488-494$

5. Basso N, Materia A, Gizzonio D, Marcelli M, De Marco M, Tamburrano G. Nutritional effects of total gastrectomy. A prospective randomized study of Rouxen-Y vs Longmire- Mouchet reconstruction. Itaj. J Surg Sci 1985; 15:335-340

6. Behrns KE, Sarr MG. Diagnosis and management of gastric emptying disorders. Adv Surg 1994:27:233-255

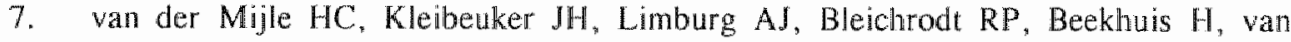
Schilfgaarde R. Manometric and scintigraphic studies of the relation between motility disturbances in the Roux limb and the Roux-en-Y syndrome. Am J Surg $1993 ; 166: 11-17$

8. Armbrecht $U$, Lundell $L$, Lindstedt $G$, Stockbrügger RW. Causes of malabsorption after total gastrectomy with Roux-en-Y reconstruction. Acta Chir Scand $1988 ; 154: 37,41$

9. Brägelmann R, Armbrecht U, Rosemeyer D, Schneider B, Zilly W, Stockbrügger RW. Nutrient malassimilation following total gastrectomy. Scand I Gastroenterol $1996 ; 31: 26-33$

10. Heil TH, Ezrodt H, Mattes P, Peros G, Herfarth CH. Gastrectomy with and without duodenal transit: release of glucagon, insulin and somatostatin. Scand J Gastroenterol 1981:16:83-87

11. Büchler M, Malfertheiner P, Glasbrenner B, Friess H, Beger HG. Secondary Pancreatic Insufficiency Following Partial and Total Gastrectomy. Nutrition $1988: 4: 314-316$

12. Fuchs M, Kohler H, Schafmayer A. Einfluss verschiedener Resektionsverfahren am Magen auf die Freisetzung von Cholecystokinin, Neurotensin und die Pankreastunktion. Zentrbl Chir 1995;120:472-477

13. Friess H, Böhm I, Müller MW, Glasbrenner B, Riepl RL, Malfertheiner P, Büchler MW. Maldigestion after total gastrectomy is associated with pancreatic insufficiency. Am J Gastroenterol 1996,91:341-347

14. Gullo L, Costa L, Ventrucci M. Mattioli S, Vitti G, Labò G. Exocrine Pancreas Function after Total Gastrectomy. Scand J Gastroenterol 1979;14:401-407 
15. Köhler H, Schafmayer A, Peiper HJ. Die sekundäre exokrine Pankreasinsuffizienz nach Magenresektion. In: Pankreas, Diagnostik. Therapie. Kozuschek W, Paquet KJ. eds. 1992:547-554

16. Mackay C. Postgastrectomy steatorrhoea. Am J Surg 1970; 120:324-348

17. Curran FT, Hill GL. Failure of nutritional recovery after total gastrectomy. Br J Surg 1990;77: 1015-1017

18. Heptner G, Domschke S, Domschke W. Exocrine Pancreatic Function After Gastrectomy - Specificity of Indirect Tests. Gastroenterology 1989:97:147\%153

19. Fuchs $\mathbb{K H}$, Thiede $A$, Engemann $R$, Deltz $E$, Stremme O. Hamelmann $H$. Reconstruction of the food passage after total gastrectomy: Randomized trial. World J Surg 1995; 19:698-705

20. Troidl H, Kusche J, Vestweber JH, Eypasch E, Maul U. Pouch versus oesophagojejunostomy after total gastrectomy: A randomized clinical trial. World I Surg 1987;11:699-712

21. Nakane $\mathrm{Y}$, Okumura $S$, Akehira K, Okamura S, Boku T, Okusa T, Tanaka K, Hioki $K$. Jejunal pouch reconstruction after tolal gastrectomy for cancer. A randomized controlled trial. Ann Surg 1995;222:27-35

22. Schwarz A, Büchler $M$, Usinger $K$, Rieger $H$, Glasbremer B, Friess $H$, Kunz R, Beger $H G$. Importance of the duodenal passage and pouch volume after total gastrectomy and reconstruction with the Ulm pouch: prospective randomized clinical study. World J Surg 1996;20:60-67

23. Stier A, Holscher AH, Schwaiger M, Siewert JR. Jejunum pouch after total gastrectomy. Clinical and scintigraphic studies of function and quality of life. Zentralbl/Chir 1994;119:838-844

24. Schmitz R, Moser $\mathbf{K H}$, Treckmann I. Lebensqualität nach prograder Jejunuminterposition mit und ohne Pouch. Eine prospektive Studie bei Magencarcinompatienten zur Frage des Reservoirs als Rekonstruktionsprinzip nach totaler Gastrektomie. Chirurg 1994;65:326-332

25. Schlag P. Buhl K, Wysocki ST, Schwartz R, Herfarth CH. Nutritional Consequences of Total Gastrectomy: Esophagojejeunostomy vs, Jejunum Pouch as Reconstructive Procedures. Nutrition 1988;4:235-8.

26. Junginger $\mathrm{TH}$, Walgenbach $S$. Postgastrectomy Reconstruction By Esophagojejunostomy Roux-en-Y. Nutrition 1988:4:239-242

27. Michielsen D, Van Hee R. Hendrickx L, Creve U, Peeters R. Functional resuls after total gastrectomy with enteric pouch reconstruction. A rewiew of 34 cases. Acta Chir Belg 1996;96:155-157

28. Roder ID, Stein HJ, Eckel F. Herschbach P. Henrich G, Böttcher K, Busch R, Siewert IR. Vergleich der Lebensqualiät mach subtotaler und totaler Gastrektomie beim Magenkarzinom. Dtsch Med Wochenschr 1996;121:543-549

29. Buhl K, Lehnert T, Schlag P. Herfarth C. Reconstruction after gastrectomy and quality of life. World J Surg $1995 ; 19: 558-564$ 
30. Roder JD, Herschbach $P$, Henrich $G$, Nagel $M$, Bötcher $K$, Siewert JR. Lebensqualität nach totaler Gastrektomie wegen Magenkarzinoms. Ösophagojejunoplicatio mit Pouch versus Ósophagojejunostomie olme Pouch. Dusch Med Wochenschr 1992;117:241-247

31. Thiede A. Magenersatzoperation und Lebensqualität. In:Fuchs KH, Hamelmann H, eds. Gastrointestinale Funktionsdiagnostik in der Chirurgie. Berlin:Blackwell Wissenschaft, 1991:222-228.

32. Herfarth C, Schlag P, Buhl K. Surgical Procedures for Gastric Substitution. World J Surg 1987:11:689-698

33. Liedman B, Andersson H, Berglund B, Bosaeus I, Hugosson I, Olbe L, Lundell L. Food intake after gastrectomy for gastric carcinoma: the role of a gastric reservoir. BJS 1996;83:1138-1143

34. de Almeida $\mathrm{AC}$, dos-Santos $\mathrm{NH}$, Aldeia FJ. Long-term clinical and endoscopic assessment after total gastrectomy for cancer. Surg Endosc 1993;7:518-23.

35. Heimbucher $J$,Fuchs KH, Freys SM, Clark GW, Incarbone R, DeMeester TR, Bremner $\mathrm{CG}$, Thiede $\mathrm{A}$. Motility in the Hunt-Lawrence pouch after total gastrectomy. Am J Surg 1994; 168:622-625

36. Li Destri G. Trombatore G, La Greca G, Rimzivillo C, Rodolico M, Desiderio C, Orsina $N$, Di Cataldo A, Puleo S. Total gastrectomy: nutritional status after three different reconstruction techniques. An experimental study. I Surg Oncol $1992 ; 49: 98-102$

37. Brägelmann $\mathbb{R}$, Armbrecht U, Rosemeyer D, Schneider B, Zilly W, Stockbrügger RW. Small bowel bacterial overgrowth in patients after total gastrectomy. Eur J Clin Invest 1997;27:409-416

38. van de Kamer JH, ten Bokkel Huinink $H$, Weyers HA. Rapid method for the determination of fat in faeces. J Biol Chem 1949;177:347-355

39. Armbrecht U, Jensen I, Eden S, Stockbrügger RW. Assessment of Oro-coecal Transit Time by Means of a Hydrogen $\left(\mathrm{H}_{2}\right)$ Breath Test As Compared with a Radiologic Control Method. Scand J Gastroenterol 1986;21:669-677

40. Affleck IW, Aitken RCB, Hunter JAA, McGuire RJ, Roy CW. Rehabilitation Status: A Measure of Mediosocial Dysfunction. Lancet 1988;1:230-233

41. Lindeman RH. Merenda PF, Gold RZ. Introduction to Bivariate and Multivariate Analysis. London:Scott, Foresman and Company, 1980. 


\section{Chapter V}

\section{The Effect of Pancreatic Enzyme Supplementation in Patients with Total Gastrectomy and Steatorrhoea}

R Brägelmann, U Armbrecht, D Rosemeyer, B Schneider, W Zilly, RW Stockbrügger 


\section{Abstract}

\section{Objective}

To assess the influence of pancreatic enzyme supplementation on symptoms, energy intake, bowel habis and fat malassimilation in patients after total gastrectomy.

\section{Design}

A prospective, double-blind, randomised, parallel, placebo-controlled multi-centre trial.

\section{Setting}

Institutionalised patients in three gastroenterological rehabilitation clinics.

\section{Participants}

52 institutionalised patients with a faecal fat output $\geq 14 \mathrm{~g} /$ day, operated on for malignant gastric disease 198 (median, interquartile range (IQR) 47 to 608) days previously, and free from recurrence and/or metastasis.

\section{Interventions}

Nine sachets of pancreatic enzymes per day (each containing lipase 36.000, anylase 27.000 , protease $2.400 \mathrm{FIP}$ ), or identicall-looking placebo were given for 14 days.

\section{Main outcome measures}

Abdominal symptoms, energy intake, bowel habits and fat malassimilation.

\section{Results}

After treatment, patients on enzyme therapy felt overall better $(p=0.006)$, but no improvement in a specific symptom could be identified. During the interwention the median kilojoule intake per kilogram body weight and day was $9 \%$ higher in the placebo group (170.8 (IQR 146.9 to 202.6)) than in the enzyme treated group (157.0 (IQR 134.8 to $170.4 y)(p=0.03)$. Enzyme treament did not result in a significant difference between the placebo and the enzyme treated group regarding bowel habits or fat malassimillation.

\section{Conclusions}

The effect of high dose pancreatic enzyme supplementation on symptoms and steatorhoea after total gastrectomy is marginal and does not justify its routine use. 


\section{Introduction}

The annual incidence and mortality rates of gastric cancer are declining in most countries, but stomach cancer is still a major cause of morbidity and mortality world-wide ${ }^{1}$. Survival rates for patients with gastric cancer are improving ${ }^{2.3}$. due to improved surgical technique ${ }^{3.5}$ and earlier diagnosis ${ }^{2.6 .3}$. If in the future an increasing number of patients is to survive gastric cancer more attention has to be directed to the post-gastrectomy situation with the problems of abdominal symptoms, anorexia, malabsorption and weight loss.

The persisting malassimilation syndrome has been attributed to changed eating habits ${ }^{8,9}$, bacterial overgrowth ${ }^{10}$, rapid upper intestinal transit ${ }^{10-12}$, primary ${ }^{13}$ or secondary pancreatic insufficiency $y^{14.15}$, deficiency of gastric lipase after total gastrectomy $^{16}$, pancreatico-cibal asynchrony ${ }^{17.28}$, or other gastrointestinal motility disorders ${ }^{19,20}$. It has been shown in patients with a Billroth II partial gastrectomy that pancreatic enzyme supplementation can reduce faecal fat excretion ${ }^{2122}$ and abdominal symptoms ${ }^{2.3}$. In spite of the discussion around the exocrine pancreatic insufficiency after total gastrectomy, there is little data concerning therapeutic intervention with enzyme supplementation. In a previous study with a small number of patients we could show that pancreatic enzyme therapy improved fat assimilation after total gastrectomy ${ }^{24}$. The aim of this study was to evaluate the effect of pancreatic enzyme supplementation on symptoms, energy intake, bowell habits and fat malassimilation in a larger and well characterised group of patients.

\section{PATIENTS AND METHODS}

\section{Patients}

This prospective study was performed at three different gastroenterological clinics in Bad Kissingen, Bad Driburg, and Bad Brückenau (all in Germany) engaged in postoperative rehabilitation. During the period from May 1990 to January 1993196 patients were seen at the three hospitals following a potentially curative total gastrectomy for gastric malignancy $(\mathrm{m}=124, \mathrm{f}=72, \mathrm{~m} / \mathrm{f}=1.7$; median age 57.0, interquartile range (IQR) 50 to 65 years). Eighty-eight patients with faecal fat of 14 grams or more per day and free from recurrence of their malignant disease were asked to participate in a prospective, randomised, parallel, double-blind, placebocontrolled, multi-centre trial of pancreatic enzyme supplementation. Two patients had a recurrence diagnosed shortly after randomisation, one suffered from an acute pancreatitis, and 33 refused to participate. The remaining 52 patients were included in the study. 


\section{Study Design}

On hospital admission a standardised history was taken, detailed surgical reports were obtained, a physical examination and standardised biochemical evaluation were performed. Body mass index according to Quetelet (mass $/$ height ${ }^{2}$ in $\mathrm{kg} / \mathrm{m}^{2}$, normall range 20.0 to 25.0 ) was calculated. Then the patients were put on a standardised diet for a period of five days during which symptoms, bowel habits, energy intake and fat assimilation were evaluated. Thereafter an $\mathrm{H}_{2}$-breath test with a standard meal including radiopaque markers was performed. The subsequent drug intervention lasted for 14 days. During the last five days of the intervention period the investigations of the initial dietary period were repeated. Two days after the intervention a second standardised interview was performed.

\section{Registration of symptoms}

Symptoms were recorded in two different ways: 1) On admission and after the intervention patients had a standardised registration of abdominal symptoms. 2) During the two periods of controlled diet in all patients faecal frequency (number/day) and faecal consistency (scale 0 to 3, "none" to "watery diarrhoea") were registered, and symptoms were scored ("symptom score", scale 0 to 3, "none at all" to "severe") daily by the authors according to a questionnaire. The five-day score of all three parameters was reported.

\section{Controlled diet period}

If patients used pancreatic enzymes on hospital admission they were asked to discontinue these. The period of controlled diet started three days later. The diet consisted of $48 \%$ fat, $17 \%$ protein, and $35 \%$ carbohydrates, respectively, and was not limited quantitatively. Individual nutritional intake was quantified during the controlled diet period at every meal by an attending dietician.

\section{Oro-coecal transit time and small bowel bacterial overgrowth}

The frequency of rapid upper intestinal transit and small bowel bacterial overgrowth were evaluated simultaneously using a modification of the $\mathrm{H}_{2}$-breath test described by Armbrecht et al. with a standard test meal and radiopaque markers ${ }^{25}$. The application of the test in the post-gastrectomy situation has been described elsewhere ${ }^{2 \hbar}$.

\section{Faecal analyses and fat assimilation}

Faecal analysis was performed during the last 72 hours of the two controlled diet periods. Mean 24-hour values for faecal mass and faecal fat (according to van de Kamer $^{27}$ ) were calculated. Fat assimilation was calculated as the proportion of fat 
excreted in relation to the intake. Faecal chymotrypsin concentration and faecal chymotrypsin output were registered in one centre (normal values $504-34769$ U/72 $\left.\mathrm{hrs}^{28}\right)$

\section{Intervention}

During 14 days participants received daily in total nine sachets of pancreatin (Pankreon Granulat). Two sachets were given with every large meal, and one sachet was given with every smaller meal. Each sachet contained lipase 36.000 , anylase 27.000 , protease $2.400 \mathrm{FIP}$, or identical-looking placebo. The pancreatic enzyme preparation used is not "enteric-coated" as all patients were achlorhydric following the total gastrectomy.

\section{Ethical considerations}

The protocol was approved by the ethical committee of the Bayerische Landesärztekammer, Germany (90109). Written informed consent was obtained from all patients after information about the study.

\section{Statistics}

The study was designed to have a statistical power of $80 \%$. Statistical calculations included the Mann-Whitney-U test for independent samples, the Wilcoxon-test for paired samples, and the $\chi^{2}$-test, with Fisher's exact test in cases necessary. An ANOVA model was used to assess the influence of pre-treatment differences in the test groups on following target variables: body mass index, kilojoule intake, fat intake, faecal consistency, faecal frequency, faecal mass, faecal fat excretion, fat malassimilation the summarising symptoms asked on admission and after intervention, and the specific symptoms that were asked during the controlled diet period. A p-value of $<5 \%$ was assumed to be statistically significant.

\section{RESULTS}

Tumour characteristics, operations, and post-operative care.

Demographical data of the patients are given in Table V.1. There were 25 patients in the placebo group and 27 patients in the enzyme treated group. The time span since operation was significantly shorter in the enzyme treated group $(p=0.03)$. In spite of intensive inquiries the exact tumour stage could not be identified in live of the 52 patients. 
Table $V .1$ Demographical parameiers in 52 patients entering the study

\begin{tabular}{|c|c|c|c|}
\hline & & Placebo & Enzymes \\
\hline \multicolumn{2}{|l|}{ Mate f fermale } & $17 / 8$ & $21 \%$ \\
\hline \multicolumn{2}{|l|}{ Age $(\text { years })^{*}$} & $57.5(50.5-61.8)$ & $56.0 \quad\{50.0-68: 0\}$ \\
\hline \multicolumn{2}{|c|}{ 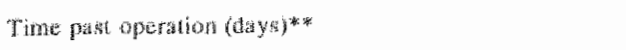 } & $390 \quad(69-869)$ & $123(39-402)$ \\
\hline \multirow[t]{7}{*}{ Tumor stage ruco) } & $\mathbb{L A B}_{\mathrm{B}}$ & $g$ & 7 \\
\hline & $1 \mathrm{~B}$ & 5 & 3 \\
\hline & II & 2 & 3 \\
\hline & IIIA & 5 & 8 \\
\hline & $111 \mathrm{~B}$ & 0 & 3 \\
\hline & IV & 2 & 1 \\
\hline & unknown & 2 & 3 \\
\hline \multirow[t]{7}{*}{ Type of operation } & Roux-en- $Y$ wilh protach & 2 & 2 \\
\hline & RoulX-en-Y wilhot prouch & 14 & 16 \\
\hline & Longmire & 2 & 8 \\
\hline & Siewen-Peiper & 0 & $\Downarrow$ \\
\hline & Schlorfer & 2 & 0 \\
\hline & ocsophago-jcjunostany & 3 & 0 \\
\hline & unkrown & 0 & 2 \\
\hline
\end{tabular}

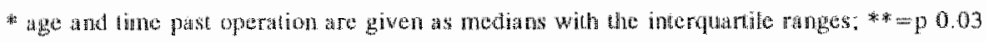

\section{Biochemistry}

Pre-study laboratory tests included haemoglobin, ferritin, albumin, calcium, faecal chymotrypsin concentration, and faecal chymotrypsin output per 72 hours. There were no significant differences regarding these parameters in the two study groups.

\section{Oro-coecal transit time and small bowel bacterial overgrowth}

The $\mathrm{H}_{2}$-breath test was unreliable regarding the diagnosis of small bowel bacterial overgrowth in two patients, because they were $\mathrm{H}_{2}$-non-producers, and in eighteen, because they had raised $\mathrm{H}_{2}$-values in combination with a rapid oro-coecal transit time. According to the $\mathrm{H}_{2}$-breath test, signs of bacterial overgrowth were present in 17 of 32 evaluable patients (placebo $8 / 15$ vs. enzymes $9 / 17$ ). A rapid oro-coecal transit time was diagnosed in 18 of 50 patients (placebo 9/23 vs. enzymes 9/25). In two patients transit time assessment was unreliable because of technical reasons. There were no significant differences between the study groups regarding the frequency of small bacterial overgrowth or rapid oro-coecal transit.

\section{Premature termination of the study}

During the intervention period the participation was prematurely ended in six 
patients (placebo $n=1$, enzyme $=5$ ): two patients complained of bloating (on enzymes), one had unspecified complaints (on enzymes), one had social reasons for an early hospital discharge (on enzymes), one was accidentally not evaluated during intervention (placebo), and in one patient faeces were accidentally not collected during the intervention (on enzymes). These six patients were excluded from the evaluation of malassimilation and calorie intake. In the last patient the data concerning symptoms were evaluated.

\section{Symptoms}

On admission there was no difference in symptom frequency between the placebo and the enzyme treated group (Table V.2).

Table V.2 Frequency of symptoms before and after intervention

\begin{tabular}{|c|c|c|c|}
\hline & & $\begin{array}{c}\text { placebo } \\
n=24\end{array}$ & $\begin{array}{c}\text { enzymes } \\
\mathbf{n}=\mathbf{2 3}\end{array}$ \\
\hline \multirow[t]{2}{*}{ Dyspepsia } & before intervention & 17 & $16^{\mathrm{mit}}$ \\
\hline & afier intervention & 13 & $8^{* *}$ \\
\hline \multirow[t]{2}{*}{ Bloating" } & before intervention & $12 / 18$ & $11 / 18$ \\
\hline & after intervention & $10 / 18$ & $7 / 8$ \\
\hline \multirow[t]{2}{*}{ Early satiety } & before intervention & $10^{* *}$ & 10 \\
\hline & after intervention & $4^{* * 4}$ & $10^{* *}$ \\
\hline \multirow[t]{2}{*}{ Reflux } & before intervention & 6 & 8 \\
\hline & after intervention & 3 & 7 \\
\hline \multirow[t]{2}{*}{ Dysphagia } & before intervention & 3 & 2 \\
\hline & after intervention & 1 & 3 \\
\hline \multirow[t]{2}{*}{ Postprandial vomiting } & before intervention & 3 & 2 \\
\hline & after intervention & 2 & 1 \\
\hline \multicolumn{4}{|c|}{ Overall improvement of symptoms } \\
\hline after intervention & not better & $18^{* * *+}$ & $8^{4 * *}$ \\
\hline after intervention & better & $6^{*+* i}$ & $15^{0.4 n}$ \\
\hline
\end{tabular}

"bloating was asked in 36 patients only; ** denotes $p<0.05 ;$ *** denotes $p<0.01$

After the intervention, dyspepsia had improved significantly $(p=0.012)$ within the enzyme treated group, but there was no significant difference when compared to placebo. The symptom of early satiety significantly decreased in the group 
receiving placebo. There was no significant effect by either treatment on any of the other symptoms. However, after intervention patients who had been on enzyme therapy reported an improvement of overall well-being significantly more often than patients on placebo $(p=0.006)$. The total symptom scores before and during the intervention period were not different between the study groups (median 0.340 on a scale from 0.000 to 3.000 in both).

\section{Body mass and energy intake}

From operation to hospital admission the median (IQR) decrease in body mass index in the total group of study patients had been $2.04 \mathrm{~kg} / \mathrm{m}^{2}(-1.04$ to 5.13$)$. This weight loss was significant in both the placebo $(p=0.04)$ and the enzyme treated $(p=0.002)$ group. At time of operation, on admission, at the start and at the end of the two weeks' intervention period there were no significant differences between the enzyme treated and the placebo treated group regarding body mass; neither was there any significant change in body mass index during therapy within either of the trial groups.

During the first dietary registration the median kilojoule intake was 10101 (IQR 8996 to 10817 ) kilojoules per day or 166.2 (IQR 134.4 to 181.3) kilojoules $/ \mathrm{kg}$ body weight and day for all patients, with no significant difference between the two study groups. During the intervention the median kilojoule intake per kilogram body weight was $9 \%$ higher in the placebo group (170.8 (IQR 146.9 to 202.6)) than in the enzyme treated group (157.0 (IQR 134.8 to 170.4)) $(\mathrm{p}=0.03)$. This difference was due to a significant increase of the median kilojoule intake in the placebo group and a non-significant decrease of kilojoule intake in the enzyme treated group. The fat intake was not significantly different between the two study groups before and during intervention.

\section{Bowel habits and steatorrhoea}

In the whole group of patients, faecal consistency was reported to be normal to soft with a median bowel frequency of 1.9 bowel movements per day. There were no significant differences of either faecal consistency or faecal frequency before and during intervention between the two groups.

In the total patient group, the median (IQR) for faecal mass and faecal fat output per day was 316 (236 to 443 ) grams and 23.0 (16.3 to 35.2 ) grams, respectively. During the intervention there was a non-significant decrease in median faecal mass and median faecal fat output in the enzyme treated group resulting in a nonsignificant trend to improved fat assimilation $(20.8 \%(16.4-30.4) ; 15.5 \%$ (9.2$24.9), p=0.1)$, whereas these parameters did not change in the placebo group $(19.4 \%(1.4 .3-27.1) ; 18.7 \%(11.7-29.1), p=0.4)$. However, neither faecal mass, faecal fat output, nor fat assimilation were significantly different between the 
placebo group and the enzyme treated group before and during intervention (Figures V.1-3).

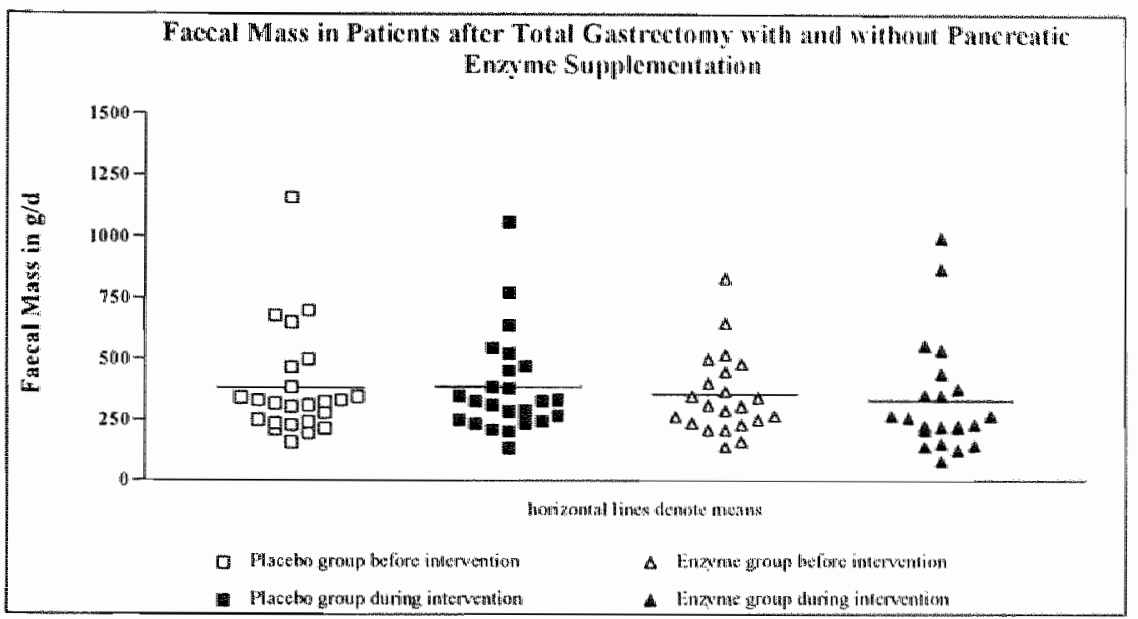

Figure V.1 Faecal mass in patients after total gastrectomy without and with pancreatic enzyme supplementation. Given are the invidual mean vallues of faecal mass per day in a 72 hour-period before and during pancreatic enzyme supplementation. The number of patients was 24 in the placebo and 22 in the enzyme group.

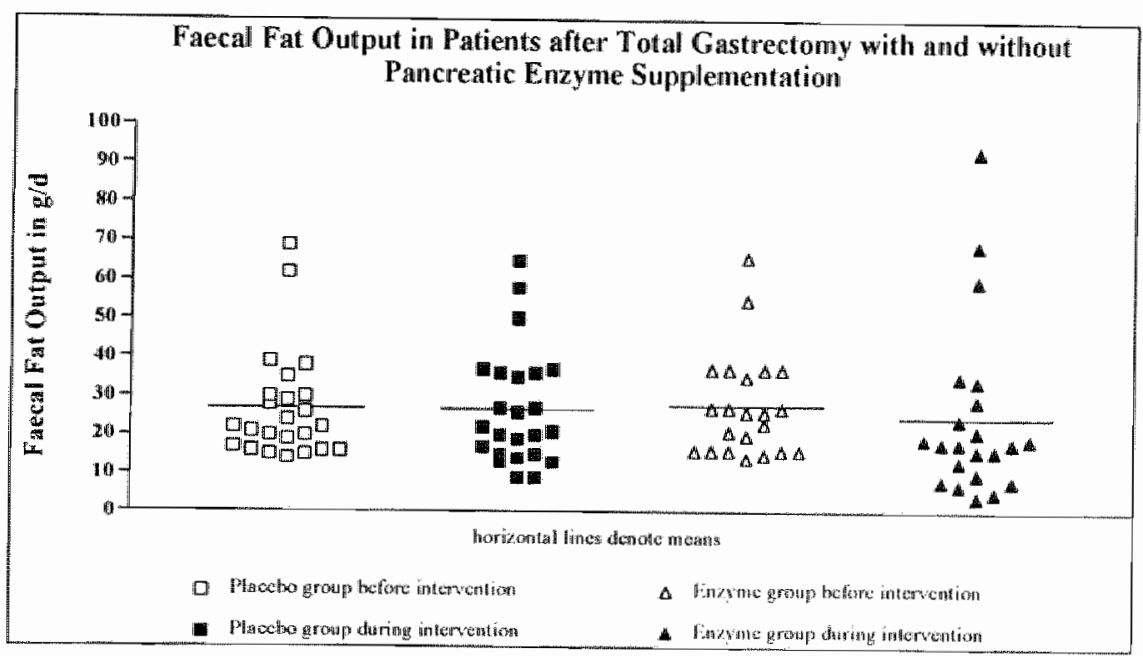

Figure V.2 Faecal fat output in patients after total gastrectomy without and with pancreatic enzyme supplementation. Given are the individual mean values of faecal fat output per day in a 72 hour-period before and during pancreatic enzyme supplementation. The number of patients was 24 in the placebo and 22 in the enzyme group. 


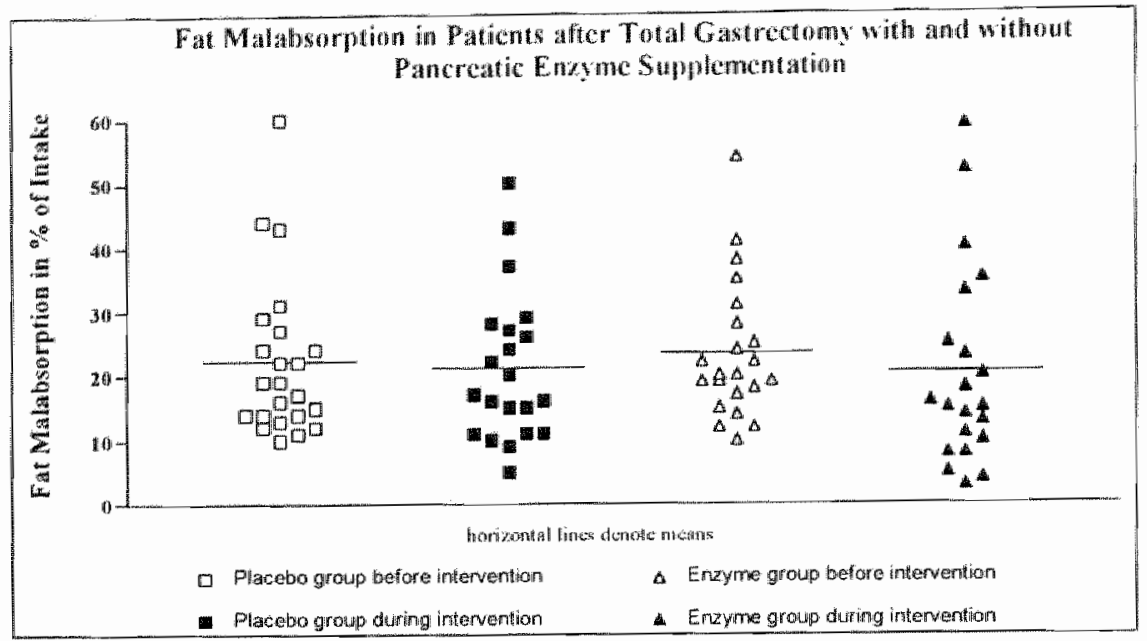

Figure V.3 Fat malabsorption in patients after total gastrectomy without and with pancreatic enzyme supplementation. Given are the individual mean values of fat malabsorption per day in a 72 hour-perilod before and during pancreatic enzyme supplementation. The number of patients was 20 in the enzyme and 22 in the placebo respectively, due to two missing values in each group.

\section{DISCUSSION}

Post-gastrectomy malabsorption probably has many causes including pancreatic maldigestion ${ }^{13-15,17,18}$. Although pancreatic exocrine insufficiency after total gastrectomy has been much investigated, there is no tinal agreement about its pathophysiological mechanisms, mainly due to the methodological problems in assessing pancreatic function after the profound change of the anatomical situation: direct measurement of enzyme output is hindered by the Roux-en-Y reconstruction, and the PABA-test, the pancreolauryl test as well as determination of faecal chymotrypsin have all shown a relatively low specificity ${ }^{29}$. The amino acid consumption test seems to have a low sensitivity ${ }^{30.32}$. The faecal elastase test might be of interest for this topic, but was not described yet when this study was started $^{33}$. The question remains whether steatorrhoea after total gastrectomy is due to primary or secondary pancreatic insufficiency combined with pancretico-cibal dyssynchrony.

It is important to remember that in exocrine pancreatic insufficiency due to chronic pancreatitis pathologically increased faecal fat output occurs only when more than $90 \%$ of the lipase function has been lost ${ }^{34}$. If exocrine pancreatic insufficiency were 
the principal causative factor in post-gastrectomy fat malassimilation supplementation with large doses of pancreatic enzymes should change this situation. In this trial we studied a group of patients - well defined regarding their symptoms, dietary habits, and weight development - with the aim of analysing the overall impact of pancreatic enzyme supplementation. To our knowledge this is the only controlled study published so far regarding this question.

After total gastrectomy, symptoms and weight loss are of major concern to patients and physicians. Frequently weight stabilises on a low level, with the risk of rapid deterioration at minor somatic or psychological stress. We did not expect that pancreatic enzyme supplementation would be able to significantly revert weight loss during a fortnight's intervention. However, if pancreatic enzyme supplementation had any effect on weight loss after total gastrectomy, the most probable ways of action were either by increasing energy intake due to less eating related symptoms ${ }^{11,35}$ and/or by improving fat absorption ${ }^{36}$. Neither of these events could be confirmed in this study.

The placebo and enzyme treated groups were similar regarding their subjective and objective pre-study parameters except for a significantly shorter time span since operation in the enzyme treated group. In an ANOVA model, the time span since operation did not influence any of the target variables and therefore does not disturb the interpretation of the main results.

The spectrum of symptoms reported by the patients was similar to what has been reported by others. Symptoms were frequent, but of low degree. This fact may have contributed to the small effect of enzyme supplementation on every single symptom investigated. The reason for the significant improvement of the overall well-being during enzyme supplementation therefore remains unclear.

The diet during the controlled diet period was not limited quantitatively, because we also wanted to assess the impact of pancreatic enzymes on energy inlake, being well aware that relative fat malabsorption after total gastrectomy is independent of intake $e^{x, 37}$.

Looking in synopsis at the effect of pancreatic enzyme supplementation after total gastrectomy in this study, it cannot be denied that there are some marginal advantages regarding subjective symptoms. However, enzyme supplementation in the high dosage applied did not lead to an increased energy intake and did not significantly alter fat malabsorption.

Pancreatic exocrine insufficiency, therefore, seems not to be the most important contributor to nutrient malassimilation after total gastrectomy. Other than in chronic pancreatitis, where enzyme supplementation can have considerable effects, these are inconspicuous after total gastrectomy. 


\section{References}

1. Parkin D, Laara E, Muir C. Estimate of the world-wide frequency of sixteen major cancers in 1980. Int J Cancer 1988:411:184-197

2. Sue-Ling HM, Johnston D, Martin IG, Dixon MF, Landsdown MRJ, McMahon MJ, Axon ATR. Gastric cancer: a curable disease in Britain. BMJ 1993;307:591595

3. Maruyama $K$, Sasako $M$, Kinoshita $T$, Sano $T$, Katai $H$. Surgical treatment for gastric cancer: the Japanese approach. Semin Oncol 1996:23:360-368

4. Pacelli F, Doglietto GB, Bellatone R, Alfieri S, Sgadari A, Cruciti F. Extensive versus limited lymph node dissection for gastric cancer: a comparative study of patients. Br J Surg 1993;80:1153-1156

5. Harrison LE, Karpeh MS, Bremnan MF. Extended Iymphadenectomy is associated with a survival benefit for node negative gastric cancer. Gastroenterology $1997: 122: A 1447$

6. Farley DR, Donohue JH, Nagorney DM, Carpenter HA, Katzmann JA, IIstrup DM. Early gastric cancer. Br J Surg 1992;79:539-542

7. Hisamichi S. Screening for Gastric Cancer. World J Surg 1989;13:31-37

8. Bradley EL, Isaacs J, Hersch $T$, Davidson ED, Milikan W. Nutritional consequences of total gastrectomy. Ann Surg 1975;182:415-429

9. Cristallo $M$, Braga $M$, Agape D, Primignani $M$, Zuliani W, Vechi $M$, Murone $M$, Sironi M, Di Carlo V, De Franchis R. Nutritional status, function of the small intestine and jejunal morphology after total gastrectomy for carcinoma of the stomach. Surg Gyn Obst 1986;163:225-230

10. Armbrecht $U$, Lundell L, Lindstedt $G$, Stockbrügger RW. Causes of malabsorption after total gastrectomy with Roux-en-Y reconstruction. Acta Chir Scand $1988 ; 154: 37-41$

11. Brägelmann R, Armbrecht U, Rosemeyer D. Schneider B, Zilly W, Stockbrügger RW. Nutrient malassimilation following total gastrectomy. Scand J Gastroenterol $1996 ; 31: 26-33$

12. Bond $\mathrm{JH}$, Levitt MD. Use of breath hydrogen $\left(\mathrm{H}_{2}\right)$ to quantitate small bowel transit time following partial gastrectomy. J Jab Clin Med 1977;90:30-36

13. Friess H, Böhm J. Müller MW "Glasbrenner B, Riepl RL, Malfertheiner P, Büchler MW. Maldigestion after total gastrectomy is associated with pancreatic insufficiency. An \Gastroenterol 1996;91:341-347

14. Büchler M, Malfertheiner P, Glasbrenner B, Beger HG. Rat exocrine pancreas function following total gastrectomy. Int I Pancreatol 1986;1:389-398

15. Gullo L, Costa L. Ventrucci M, Mattioli S, Vitti G, Labò G. Exocrine Pancreas Function after Tolal Gastrectomy. Scand I Gastroenterol 1979:14:401-407

16. Carriere F, Barrowman JA, Verger R, Laugier R. Secretion and Contribution to Lipolysis of Gastric and Pancreatic Lipases During a Test Meal in Humans. Gastroenterology 1993; 105:876-888 
17. Leth RD, Abrahamsson $H$, Kilander A, Lundell LR. Malabsorption of fat after partial gastric resection. A study of pathophysiological mechanisms. Eur I Surg $1991 ; 157: 205-208$

18. Armbrecht U, Brägelmann R, Baumgart I, Stockbrügger RW. Fecal Chymotrypsin Output in Relation To Fecal Fat after Partial and Total Gastrectomy. Gastroenterology 1994; 106:A219

19. Faß J, Bares R, Staude M, Schumpelick V. Type of stomach replacement and intestinal motility after total gastrectomy. Leber Magen Darm 1993:23:194-203

20. Miholic J, Meyer HJ, Müller MJ, Weimann A, Pichlmayr R. Nutritional consequences of total gastrectomy. The relationship between mode of reconstruction, postprandial symptoms, and body composition. Surgery $1990 ; 108: 488-494$

21. Hillman HS. Postgastrectomy malnutrition. Gut 1968;9:576-584

22. Worning $H$. The effect of enzyme substitution in patients with pancreatic insufficiency. Scand J Gastroenterol 1980;15:529-533

23. Tillander H, Tveit E. Beeinflussung des Dumping-Syndroms mit Pankreon. Münch Med Wschr 1978:120:1717-1718

24. Armbrecht $U$, Lundell $L$, Stockbrügger RW. The benefit of pancreatic enzyme substitution after total gastrectomy. Aliment Pharmacol Therap 1988;2:4493-4500

25. Armbrecht U, Jensen J, Eden S, Stockbrügger RW: Assessment of Oro-coecal Transit Time by Means of a Hydrogen $\left(\mathrm{H}_{2}\right)$ Breath Test As Compared with a Radiologic Control Method. Scand J Gastroenterol 1986;21:669-677

26. Brägelmann R, Armbrecht U, Rosemeyer D, Schneider B, Zilly W, Stockbrügger RW. Small bowel bacterial overgrowth in patients after total gastrectomy. Eur J Clin Invest 1997;27:409-16

27. van de Kamer JH, ten Bokkel Huinink $\mathbb{H}$, Weyers HA. Rapid method for the determination of fat in faeces. J Biol Chem 1949;177:347.355

28. Stockbrügger RW, Armbrecht U. Determination of Faecal Chymotrypsin Concentration and 72- Hour Faecal Chymotrypsin Output in the Detection of Pancreatic Steatorrhoea. Scand J Gastroenterol 1991;188:13-19

29. Heptner G, Domschke S, Domschke W. Exocrine Pancreatic Function After Gastrectomy - Specifity of Indirect Tests. Gastroenterology 1989;97:147-153

30. Lembcke B, Konle O, Duan LP, Caspary WF. Lack of accuracy of plasma $\alpha$-amino nitrogen profiles as an indicator of exocrine pancreatic function both after continuous and bolus stimulation of the pancreas with secretin and choecystokininpancreozymin. Z Gastroenterol 1994;32:679-683

31. Maringhimi A, Nelson DK, Jones ID, DiMagno EP. Is the plasma amino acid consumption test an accurate test of exocrine pancreatic insufficiency? Gastroenterology 1994;106:488-493

32. Kemmer TP, Malfertheiner $P$, Häberle H, Pohlandi F, Friess H, Büchler M. Die diagnostische Wertigkeit des Aminosäurenabsorptionstest beim Nachweis einer exokrinen Pankreasfunktionsstörung. Z Gastroenterol 1992;30:391-396

33. Stein J, Schoonbroodt D, Jung M, Lembcke B, Caspary WF. Measurement of fecal elastase 1 by immunoreactivity: a new indirect test of the pancreatic function. Gastroenterol Clin Biol 1996:20:424-429 
34. DiMagno EP, Go VLW. Summerskill WHJ. Relations between pancreatic enzyme output and malabsorption in severe pancrearic insufficiency. $N$ Eng $J$ Med $1973 ; 288: 813-815$

35. Bozzetti F, Bonfanti G, Castellani R, Maffioli L, Rubino A, Diazzi G, Cozzaglio L, Gennari $L$. Comparing reconstruction with Roux-en-Y to a pouch following total gastrectomy. J Am Coll Surg 1996;183:243-248

36. Liedman B. Andersson H, Bosaeus MD, Hugosson BSC, Lundell L. Changes in Body Composition after Gastrectomy: Results of a Controlled Prospective Clinical Trial. World J Surg 1997;21:416-421

37. Schwartz MK, Bodansky O, Randal L. Metabolism in surgical patients. II. Fat and mineral metabolism in totally gastrectomized patients. Am J Clin Nutr 1956;4:51-60 


\section{Chapter VI}

\section{The Influence of Rapid Oro- coecal Transit Time on Symptoms, Clinical Signs, and Nutrient Assimilation in Patients after Total Gastrectomy}

R Brägelmann, U Armbrecht, D Rosemeyer, B Schneider, W Zilly, RW Stockbrügger 


\section{Abstract}

\section{Purpose}

To determine the influence of rapid oro-coecal transit time on symptomatology, clinical signs and nutrient malassimilation after total gastrectomy.

\section{Patients and Methods}

97 patients after potentially curative total gastrectomy for gastric malignancy were evaluated for symptoms and signs of malassimilation. Oro-coecal transit time was assessed with a radiographically controlled $\mathrm{H}_{2}$-breath-test. 62 patients had a normal transit time and 35 of the patients had an oro-coecal transit time $<75$ minutes.

\section{Results}

Bloating was significantly more frequent in patients with a rapid oro-coecal transit $(p=0.03)$. They also had a significantly greater faecal fat output $(p<0.02)$ and malassimilation of ingested fat $(p<0.05)$ than patients with normal transit.

\section{Conclusions}

After total gastrectomy, a small bowel transit time shorter than 75 minutes is associated with marked fat malassimilation. In these patients studies are needed on medical intervention aiming at prolonging oro-coecal transit. 


\section{Introduction}

The oro-coecal transit time (OCTT) covers the passage of food through the oesophagus, the stomach and the small intestine. During this time nutrients are mixed, portioned, digested and absorbed.

Oro-coecal transit time can be assessed using $\mathrm{H}_{2}$-breath tests with different substrates such as lactulose $e^{1.2}$ and standard meals ${ }^{3.4}$, or by scintigraphic investigations ${ }^{3.7}$. The average value for the oro-coecal transit time with standard meals $s^{3.4}$ and scintigraphic methods $s^{6-12}$ is about 4 hours. Tests using lactulose result in more rapid small intestinal transit, which may render physiological assessment difficult $t^{2.13}$.

Various factors influence the oro-coecal transit time. Whereas the influence of the age on oro-coecal transit time is controversial ${ }^{6.14-16}$, intestinal transit as measured with the $\mathrm{H}_{2}$-breath test is prolonged in the luteal phase of the menstrual cycle ${ }^{17}$. Size and composition of gastric contents ${ }^{18}$ as well as volume of gastric secretion ${ }^{19}$ seem to be of importance. Proteolytic activity of the pancreas slows oro-coecal transit ${ }^{20}$. Short ${ }^{21}$ and medium chain fatty acids ${ }^{22}$ in the ileum accelerate oro-coecal transit, whilst long chain fatty acids prolong it ${ }^{21,23-26}$. However, some authors could not show an influence of long chain fatty acids on small bowel transit time $e^{22.27}$. Extended duration of lipid exposure may lead to adaptation of the small intestine ${ }^{28.29}$.

In the situation after total gastrectomy there are profound motility changes ${ }^{30-40}$. Although the anatomical oro-coecal distance is shortened, transit time is not necessarily faster than in healthy controls ${ }^{30,31.44}$. The frequency of an oro-coecal transit time below 75 minutes after total gastrectomy as assessed with a radiographically controlled $\mathrm{H}_{2}$-breath test is by our group reported to be around $36 \%$ \%

A rapid oro-coecal transit time can cause malabsorption of all nutrients ${ }^{43.44}$. In our own previous small study oro-coecal transit time was inversely correlated to postoperative weight loss after total gastrectomy ${ }^{42}$. The aim of the present study was to elucidate in a large representative patient population whether rapid oro-coecal transit influences symptoms, biochemical parameters, and - most importantly nutrient assimilation after total gastrectomy.

\section{Patients and methods}

During the period from May 1990 to January 1993, 196 consecutively admitted patients following a potentially curative total gastrectomy for gastric malignancy were seen at three German gastroenterological rehabilitation hospitals in Bad Kissingen, Bad Driburg, and Bad Brückenau. In Germany after major surgery, patients have the opportunity of one or several post-operative admissions to a 
rehabilitative centre. Therefore, the patients of the present study were electively referred for rehabilitative purposes without known other serious disease. Of the 196 pattents, 14 were admitted for the second time, and in eight patients a recurrence and/or metastasis was diagnosed shortly after admission. These patients were excluded from this study. The remaining 174 consecutive patients were considered for this study.

\section{Basic evaluation}

After clinical, haematological and biochemical evaluation on admission, all patients were asked whether they suffered from the following abdominal symptoms: dyspepsia, bloating, early satiety, reflux, dysphagia, dumping, vomiting; also overall well-being was evaluated. Body mass was evaluated using the Quetelet index (weight/height ${ }^{2}$; normal range 20.0 to $25.0 \mathrm{Kg} / \mathrm{m}^{2}$ ).

\section{Employment Status and Medico-social functioning}

The employment status was recorded on admission. In order to assess medicosocial functioning the Edinburgh Rehabilitation Status Scale (ERSS) was applied on admission by one of the authors. The Edinburgh Rehabilitation Status Scale has been tested in several somatic patient groups in rehabilitative medicine ${ }^{45}$. The scale ranges from 0 to 28 points, with higher figures indicating a poorer medico-social functioning. The ERSS measures the dimensions of medico-social performance in four different subscales: Independence, activity, social integration, and effects of symptoms on life style. Subscale points are summed up to the final score.

\section{Controlled diet period}

Patients on pancreatic enzyme supplementation at the time of hospital admission were asked to discontinue this at least three days before the following evaluation started. All patients were then put on a standardised diet for five days. During the diet period, meals were composed of $48 \%$ fat, $17 \%$ protein, and $35 \%$ carbohydrates, respectively. The individual nutritional intake was quantified at every meal by an attending dietician and summarised each day. During the period of controlled diet abdominal complaints, faecall frequency, and faecal consistency were scored daily according to a questionnaire-interview (score 0 to 3) and a fiveday average score of each parameter was reported.

\section{Fat malassimilation}

During the last three days of the controlled diet period faecal mass and faecal fat output were assessed, the latter according to the method of van de Kamer ${ }^{46}$. Fat assimilation was calculated as the proportion of fat output compared to the intake. 
In one centre, Bad Kissingen, chymotrypsin concentration and output per 72 hours were measured. Normal values for the latter are 504-34769 U/72 hours ${ }^{47}$.

\section{Endoscopy}

An upper endoscopy was performed in each patient, unless it had been performed during the previous two months. In these cases the endoscopic diagnosis from the last examination was recorded.

\section{Oro-coecal transit time as assessed with the $\mathrm{H}_{2}$-breath test with radiopaque markers}

Rapid upper intestinal transit - defined as an oro-coecal transit time below 75 minutes $^{42}$ - and small bowel bacterial overgrowth were evaluated simultaneously using a modification of the $\mathrm{H}_{2}$-breath test described by Armbrecht et $\mathrm{al}^{4}$ : Medical records were scrutinised to ensure that no antimicrobial treatment had been given during the two previous weeks. After a low-fibre diet during the day before the test and an overnight fast ${ }^{48}$, end-expiratory $\mathrm{H}_{2}$-concentrations were serially analysed every 15 minutes, starting 15 minutes prior to the test breakfast, the composition of which is shown in Table VI.1. Ten radiopaque markers $(6.0 \times 1.8 \mathrm{~mm})$ were added to the test meal to indicate transil into the coecum. $\mathrm{H}_{2}$-concentrations were measured with a GMII Exhaled $\mathrm{H}_{2}$ Monitor (GMI Medical Ltd., Inchinnan Estate, Renfrew, Scotland). Samples were taken by direct insufflation via a $\mathrm{Y}_{\text {-piece with }}$ nlow reduction ${ }^{48}$. Duplicate samples were taken at each time point, and the arithmetic mean of these two measurements was used for evaluation.

Table V1.1 Composition of the standard test meal for the combined assessment of the orocoecal transit time and upper gastrointestinal bacterial overgrowth

\begin{tabular}{lccc}
\hline Water & 150 & $\mathrm{ml}$ \\
\hline Porridge made from & watter & 200 & $\mathrm{ml}$ \\
& milk & 50 & $\mathrm{ml}$ \\
& rolled odts & 36 & $\mathrm{~g}$ \\
White bread & & 50 & $\mathrm{~g}$ \\
Margarine & 10 & $\mathrm{~g}$ \\
Cheese (16\% fal) & 13 & $\mathrm{~g}$ \\
Smoked medwurst & 12 & $\mathrm{~g}$ \\
Total energy content & 2.0 & $\mathrm{MJ}$ \\
Energy contribution from carbohydrate & 39 & $\%$ \\
l0 radiopaque markers & & $\%$ \\
\hline
\end{tabular}


Seventy-five minutes after the start of the breakfast a plain abdominal $x$-ray was taken to detect oro-coecal transit shorter than 75 minutes. If the first radiopaque marker(s) had reached the coecal area or the ascending colon, the patient was assumed to have a rapid oro-coecal transit. In this case the further examination was stopped. In all other cases a second radiograph was taken when a $100 \%$ rise occurred above base line values of breath $\mathrm{H}_{2}$-concentration, in order to differentiate between upper intestinal bacterial overgrowth and transit of the test meal into the colon. If markers were identified in the colon, the time point was recorded as the oro-coecal transit time. If markers were still in the small intestine, it was concluded that oro-coecal transit was longer than the time period measured and that patients had small intestinal bacterial overgrowth. The test was ended at 210 minutes irrespective of markers having reached the colon or not. Therefore, absolute values for transit times below 75 minutes and above 210 minutes cannot be given in this paper. Patients with an oro-coecal transit time longer than 210 minutes were evaluated mathematically as having an oro-coecal transit time of 210 minutes. Figure VI.1. exemplifies four possible test results.

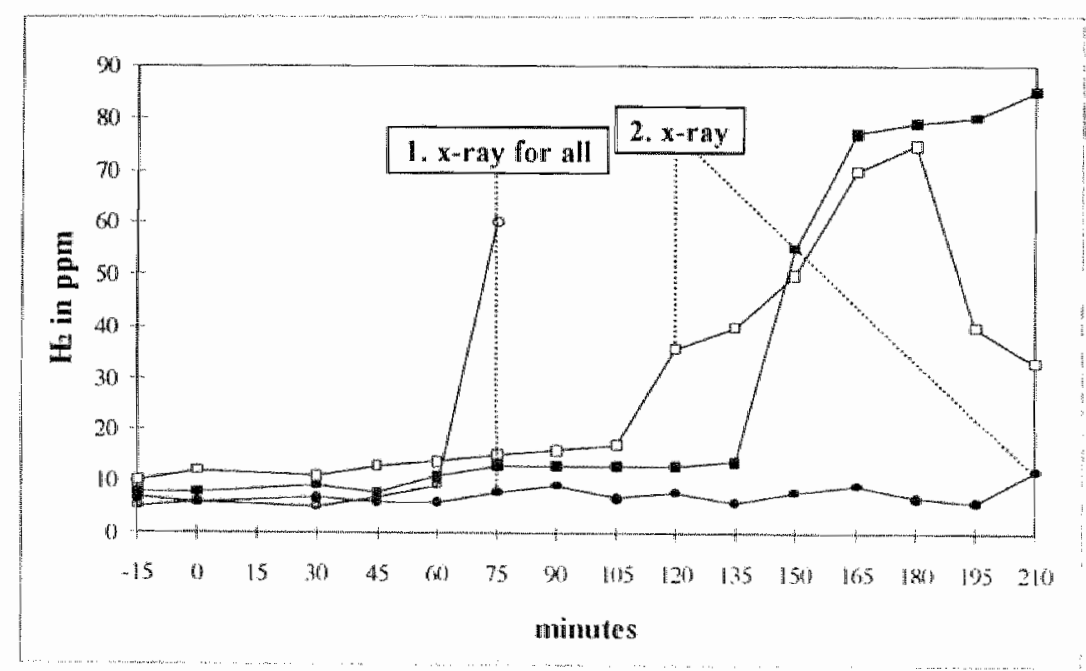

Figure VI.l Measurements of oro-coecal transit time in patients after total gastrectomy with normal of with rapid oro-coecal transit (OCTT $<75$ minutes). Examples of $\mathrm{H}_{2}$ breath tests with a test breakfast as used in this study. The line with the filled circles denotes a patient withour bacterial overgrowth and an oro-coecal transit time exceeding 210 minutes. The line with the black squares denotes al patient without bacterial wergrowth in whom markers were idenutied in the ascending colon at 150 minutes. The line with the white squares denotes at patient with bacterial overgrowth. At 120 minutes there is a rise in $\mathrm{H}_{2}$-concentration, but markers were identified in the simall intestine; the OCTT could therefore not be measured. The line with the white circles denotes a patient with an oro-coecal transit time below 75 minutes as the $\mathrm{H}_{2}$-values were already rising and radiopaque markers were identified in the ascending colon at 75 minutes. 


\section{Statistics}

Statistical calculations included the $\chi^{2}$-tests and Mann-Whitney $U$ test. A p-ralue of 0.05 was considered to be significant. The protocol was approved by the ethical committee of the Bayerische Landesärztekammer, Germany.

\section{Results}

The radiographic evaluation of the complete oro-coecal transit could not be performed in 30 patients $(f=9, m=21$; median age $=53$ years, interquartile range $(I Q R)=50$ to 63 ) because of technical reasons. Another forty-seven patients had small bowel bacterial overgrowth. A detailed report regarding these patients is given elsewhere ${ }^{49}$. These two patient groups were excluded from the further analysis. The remaining 97 patients $(\mathrm{f}=33, \mathrm{~m}=64$; median age $=58$ years, interquartile range (IQR) $=50$ to 67) were evaluable. In these, the total gastrectomy for gastric malignancy had taken place 226 days earlier (median; IQR 63 to 727).

Patients with a transit time $\geq 75$ minutes $(n=62 ; 64 \%)$ were compared with patients with rapid oro-coecal transit defined as $<75$ minutes $(n=35 ; 36 \%)$. Figure VI.2 gives the distribution of the oro-coecal transit times for the patients of the three different clinics; the frequency of rapid and normal oro-coecal transit times did not differ between the three clinics, 46 patients (47\%) had an oro-coecal transit time of 210 minutes or more.

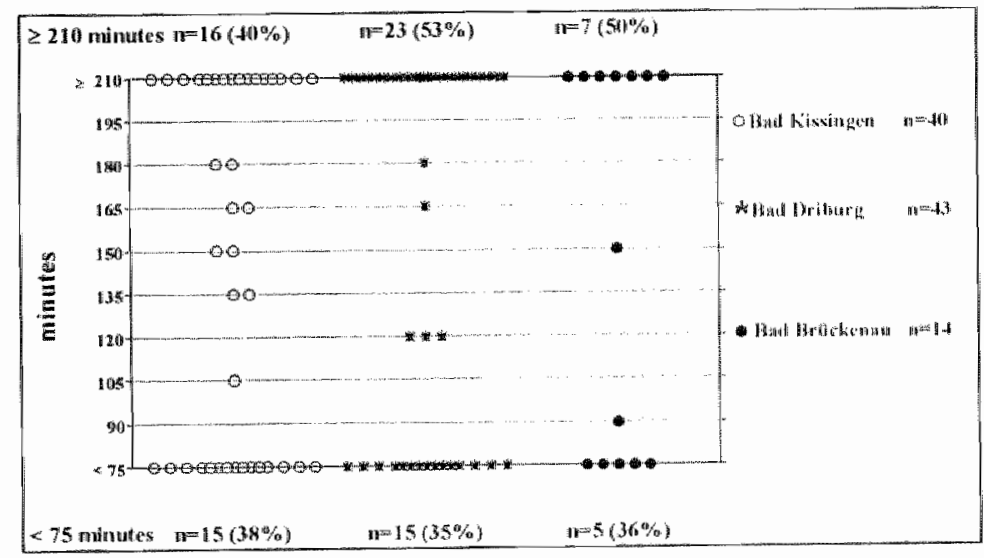

Figure VI.2 Oro-coecal transit time in patients after total gastrectomy with normal and with rapid oro-coecal transit (OCTT $<75$ minutes). Giwen are the oro-coecal transit time for 97 patients after total gastrectomy with normal and with rapid $(<75$ minutes) oroncoecal transit from Bad Kissingen, Bad Driburg, and Bad Bruckenau. The $\geq 210$-minutes-line denotes values that are $\geq 210$ minutes and the 75 -minute-line denotes values that are $<75$ minutes. Absolute values for transit times above 210 minutes and below 75 minutes cannot be given becadse of methodological reasons. 
There were no significant differences between the two transit-time groups regarding gender, age, lime since operation, tumour stage, and type of operation (Table VI.2).

Table VI.2 Gender, age, time since operation, tumour stage and type of operation in patients with normal or with rapid oro-coecal transit (OCTT $<75$ minutes)

\begin{tabular}{|c|c|c|c|c|}
\hline & \multicolumn{2}{|c|}{$O C T T \geq 75$ minutes $(n=62)$} & \multicolumn{2}{|c|}{ OCTT $<75$ minutes $(n=35)$} \\
\hline Male/Female & 41121 & & $23 / 12$ & \\
\hline Age (yearsis $)^{*}$ & $n=61$ & $57(50-67)$ & $\mathrm{n}=35$ & $59(52-68)$ \\
\hline Time past operation (days) & $n=60$ & $309(86-747)$ & $n=34$ & $164(55-656)$ \\
\hline Turnour stage 0 & 1 & & 0 & \\
\hline $\mathrm{M}$ & 18 & & 13 & \\
\hline $\mathbb{I B}$ & 12 & & 9 & \\
\hline II & 9 & & 3 & \\
\hline IIIA & 9 & & 3 & \\
\hline IIIIB & $\mathbb{1}$ & & 2 & \\
\hline IV & 2 & & 3 & \\
\hline Lymphomas & 10 & & 2 & \\
\hline Roux-en-Y without pouch & 30 & $48 \%$ & 22 & $62 \%$ \\
\hline Roux-en-Y with pouch & 13 & $21 \%$ & 2 & $6 \%$ \\
\hline Small bowel interposition & 6 & $10 \%$ & 7 & $20 \%$ \\
\hline Unknown & 13 & $21 \%$ & 4 & $11 \%$ \\
\hline
\end{tabular}

"median and interquartile range (lQR); one missing walue;" for time past operation three missing values

Symptoms were present in almost all patients (Table VI.3). Bloating and dyspepsia were the most common complaints. Bloating was significantly more frequent in patients with an oro-coecal transit time below 75 minutes than in those with longer transit time ( $82 \%$ vs. $52 \% ; \mathrm{p}=0.03)$. There were no other significant differences in symptom frequency and symptom severity between the groups. 
Table V1.3 Frequency and severity of symptoms on admission in patients with normat or with rapid orowcoecal transit (OCTT $<75$ minutes)

\begin{tabular}{|c|c|c|c|c|c|c|}
\hline & \multicolumn{3}{|c|}{ OCTT $\geq 75$ mimutes $(n=62)$} & \multicolumn{3}{|c|}{ OCTT $<75$ minutes $(n=35)$} \\
\hline & $n$ & $\%$ & & n & $\%$ & \\
\hline Bloating" & $13 / 25$ & 52 & & $18 / 22$ & 82 & \\
\hline Dyspepsia & 37 & 60 & & 27 & 77 & \\
\hline Early stiety & 36 & 58 & & 20 & 57 & \\
\hline Retux & 16 & 26 & & 10 & 29 & \\
\hline Dysphagia & 9 & 15 & & 7 & 20 & \\
\hline Postprandial womiting & 10 & 16 & & 3 & 9 & \\
\hline \multirow[t]{2}{*}{ Any symptoms } & 51 & 82 & & 33 & 94 & \\
\hline & & med $^{* * i}$ & IQR & & $\operatorname{med}^{\text {**** }}$ & IQR \\
\hline Symptomscore & 61 & 0.290 & $0.030-0.715$ & 35 & 0.450 & $0.280-0.570$ \\
\hline
\end{tabular}

- bloating was asked in 47 patients, $p=0.03$; "scale from 0.000 to $3.000 ;$ " med denotes median; IQR denotes interquartile range

The Edinburgh Rehabilitation Status Scale (ERSS) used as a measure of medicosocial functioning and the employment status were not different between the two groups (Table VI.4).

Table VI.4 Employment status and Edinburgh Rehabilitation Status Scalle (ERSS) on admission in patients with normal or with rapid oro-coecal transit (OCTT $<75$ minutes)

\begin{tabular}{|c|c|c|c|c|c|c|c|}
\hline & & \multicolumn{3}{|c|}{ OCTT $\geq 75$ minutes } & \multicolumn{3}{|c|}{ OCTT $<75$ minutes } \\
\hline & & $n=62$ & $\%$ & & $\mathrm{n}=35$ & $\%$ & \\
\hline \multicolumn{8}{|c|}{ Employment status } \\
\hline Working & & 8 & 13 & & 4 & \|\| & \\
\hline Not working & due to ill health & 16 & 26 & & 12 & 34 & \\
\hline Early retirement & due to ill health & 5 & 8 & & 0 & 0 & \\
\hline Retirement & due to age & 19 & 31 & & 15 & 43 & \\
\hline Unemployed & & 14 & 23 & & 4 & $\| 1$ & \\
\hline \multirow{2}{*}{\multicolumn{2}{|c|}{ Working/potentially working }} & $8 / 29$ & 28 & & $4 / 16$ & 25 & \\
\hline & & & med" & IQR & & med" & IQR \\
\hline ERSS (0 to 28, & st to worst) & 62 & 3.0 & $1.0-5.0$ & 34 & 3.5 & 1.060 .0 \\
\hline
\end{tabular}

* med denotes median: IQR denotes interquartile range 
Endoscopic findings in patients with an oro-coecal transit time below 75 minutes were not different from findings in patients with normal transit.

In the total patient population the median body mass index on admission was 21.9 $\mathrm{kg} / \mathrm{m}^{2}$ (IQR 20.0 to 24.0 ). The median weight loss since operation had been $9.2 \%$ (IQR -2.6 to 16.3). The median calorie intake during the controlled diet period was 2347 kilocalories per day (median, IQR 2004 to 2600), accounting for a median calorie intake of 38.0 (IQR 30.0 to 43.1) kilocalories per kilogram body weight and day (Table VI.5).

Table V1.5 Weight development and energy intake in patients with normal or will rapid oro-coecal transit (OCTT< $<5$ minutes)

\begin{tabular}{lcccccc}
\hline & \multicolumn{3}{c}{ OCTT $\geq 75$ minutes } & \multicolumn{3}{c}{ OCTT < 75 minutes } \\
& $\mathrm{n}$ & median & IQR & $\mathrm{n}$ & median & IQR \\
\hline BMI $\left(\mathrm{kg} / \mathrm{m}^{2}\right)$ & 62 & 22.0 & $20.0-24.0$ & 35 & 22.4 & $20.0-24.2$ \\
Weight loss (\%) & 62 & 8.7 & $-4.8-14.2$ & 35 & 10.3 & $-1.7-16.7$ \\
Calorie intake (kcal/day) & 61 & 2378 & $1946-2600$ & 34 & 2380 & $1973-2582$ \\
Calorie intake* & 58 & 38.0 & $29.6-41.9$ & 30 & 39.4 & $29.8-44.0$ \\
Fadt intake (g/day)" & 61 & 121 & $99-133$ & 34 & 122 & $101 \% 132$ \\
\hline
\end{tabular}

IQR denotes interquartile range: " during a five day period: "** denotes kilocalories per $\mathrm{kg}$ bodly weight and day

Haematological and biochemical data on hospital admission were comparable in patients with normal transit and patients with rapid oro-coecal transit (Table VI.6).

Table VI.6 Halematological and biochemical dattd on hospital admission in patients with normal or with rapid oro-cecal transit (OCTT $<75$ minutes)

\begin{tabular}{llccccccc}
\hline & normal range & \multicolumn{3}{c}{ OCTT $\geq 75$ minutes } & \multicolumn{3}{c}{ OCTT <75 minutes } \\
& & $\mathrm{n}$ & median & IOR & $\mathrm{n}$ & median & IQR \\
\hline Harnoglotin $(\mathrm{g} / \mathrm{L})$ & $133-177$ & 61 & 137 & $127-149$ & 35 & 133 & $124-140$ \\
Ferritin $(\mu \mathrm{g} / \mathrm{L})$ & $20-400$ & 60 & 38 & $16-92$ & 33 & 61 & $18-197$ \\
Albumin $(\mathrm{g} / \mathrm{L})$ & $35.2-50.4$ & 60 & 44 & $41-48$ & 32 & 45 & $40-48$ \\
Calcium $(\mathrm{mmol} / \mathrm{L})$ & $2.20-2.50$ & 60 & 2.35 & $2.28-2.48$ & 31 & 2.34 & $2.27-2.48$ \\
FOBT & & & $2 / 59$ & $3 \%$ & & $1 / 35$ & $3 \%$ \\
\hline
\end{tabular}

IQR denotes interquartille range: "corrected for albumin; FOBT denotes faecal occult blood fest (at least 1 of 3 slides positive) 
Bowel habits were not different between the two groups. Median faecal mass tended to be higher in the patients with an oro-coecal transit time below 75 minutes compared to patients with a normal oro-coecal transit time. In none of these parameters was there a significant difference between the two study groups (Table VI.7).

Table VI.7 Bowel habits in patients with normal or with rapid oro-coecal nansit (OCTT $<75$ minutes)

\begin{tabular}{lccccccc}
\hline & \multicolumn{3}{c}{ OCTT $\geq 75$ minutes } & \multicolumn{3}{c}{ OCTT $<75$ minutes } \\
& $\mathrm{n}$ & median & $\mathrm{IQR}$ & $\mathbf{n}$ & median & $\mathbb{1 Q R}$ \\
\hline Faecall consistency & 62 & 1.0 & $1.0-2.0$ & 35 & 1.2 & $1.0-2.0$ \\
Faecal frequency per day & 59 & 1.2 & $1.0-2.0$ & 35 & 1.6 & $1.0-2.0$ \\
Faecal mass & \\
\hline
\end{tabular}

IQR denotes interquatile range; "faecal consistency is ranked: $0=$ no faecs, $1=$ normally formed, $2=$ soft, $3=$ watery diarrhoea, scale from 0.0 to $3.0 ;$ * one centre reported no faecal mass

The median faecal chymotrypsin concentration was significantly lower in patients with oro-coecal transit time below 75 minutes compared to the remainder $(2.7$ (IQR 2.1 to 4.6 ) vs. 4.9 (IQR 2.9 to 7.2 ) U/g; $p<0.05$ ). Also, median faecal chymotrypsin output during 72 hours tended to be lower in the patients with an oro-coecal transit time below 75 minutes. However, this difference was statistically not significant $(p=0.2$ ) (Table VI.8).

Table VI.8 Faecall chymotrypsin concentration and faecal chymotrypsin output on hospital admission in 35 patients with normal or with rapid oro-coecal transit (OCTT $<75$ minutes)

\begin{tabular}{lllllllll}
\hline & mormal range & \multicolumn{3}{c}{ OCTT $\geq 75$ mimutes } & \multicolumn{3}{c}{ OCTT <75 minutes } \\
& & & n & median & IQR & n & median & IQR \\
\hline Chym (U/g)* & $>6$ & 20 & 4.9 & $3.2-7.5$ & 15 & 2.7 & $2.1-4.6$ \\
Chym-out (U/72hrs) & $504-34769^{* * *}$ & 20 & 2916 & $1572-3942$ & 15 & 2097 & $1167-3699$ \\
\hline
\end{tabular}

1OR denotes interquartile range: "Chym denotes chymotrypsin concentrations in faeces, $p<0.05$; * Chym-out denotes faecal chymotrypsin outpur during 72 bours, $p=0.2$; *** according to Stockbrügger et all. ${ }^{47}$

Patients with rapid oro-coecal transit had a $50 \%$ higher median daily faecal fat output $(\mathrm{p}<0.02)$ (Figure VI.3) and a $47 \%$ higher fat malassimilation $(\mathrm{p}<0.05)$ (Figure VI.4) compared to patients with normal transit. The number of patients 
with a daily faecal fat output exceeding 14 grams was $24 / 62(39 \%)$ in the group with normal oro-coecal transit time versus $22 / 34(65 \%)$ in those patients with rapid oro-coecal transit $(\mathrm{p}=0.02)$.

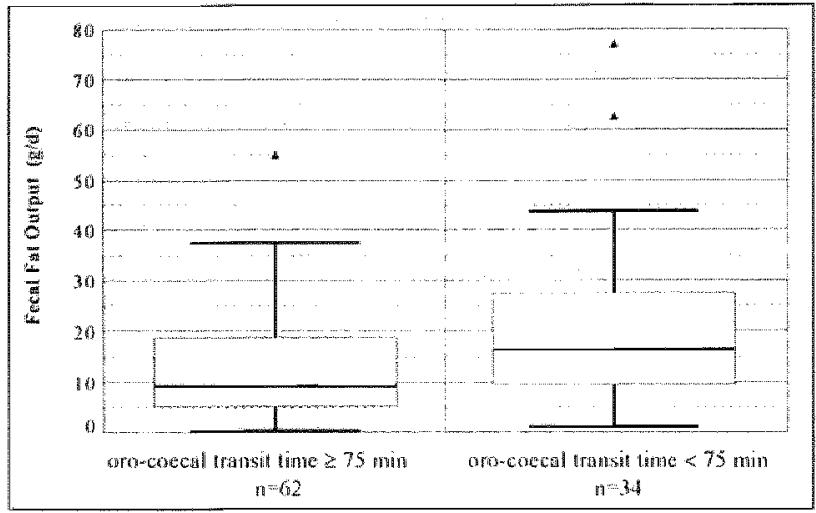

Figure VI.3 Fated fat output in patients after total gastrectomy with normall or with rapid oro-coecal transit (OCTT $<75$ minutes). Faecal fat output of patients without $(\mathrm{n}=62)$ and patients with $(n=34)$ an oro-coecal transit time below 75 minutes in whisker-boxplots. The lower boundary of the boxes is the $25^{\text {th }}$ percentile, the upper boundary is the $75^{\text {th }}$ percentile, the line in the box represents the median. The triangles denote outliers, which are defined as cases with a value 1.5 to 3 box-lenghts from the edge of the box. The whiskers show the highest and lowest values that are not outliers. In one patients data was missing.

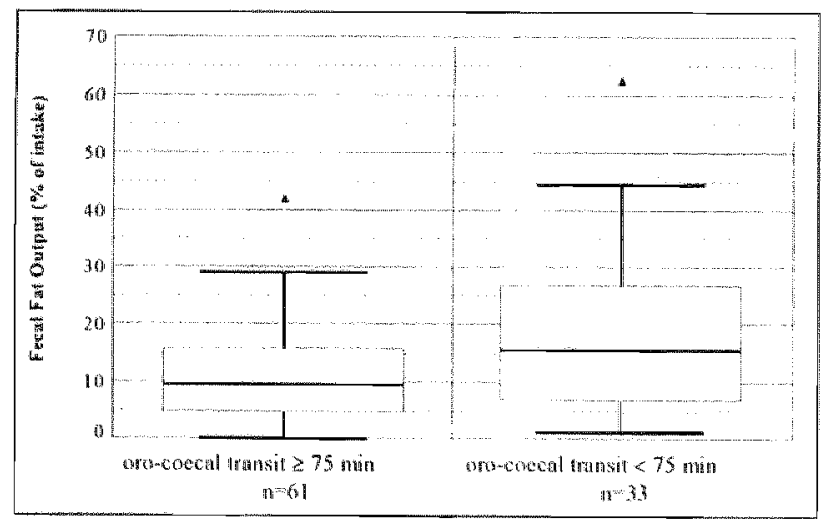

Figure VI.4 Fatt mallassimilation in patients atter total gastrectomy with normal or with rapid oro-conecal transit (OCTT $<75$ minutes). Fat output in $\%$ of intake in patients without $(n=61)$ and patients with $(n=33)$ an oro-coecal transit time below 75 minutes in whisker-boxplots. The definition of the box plots is as in figure VI.3. In three patients data was missing. 


\section{Discussion}

Patients with a potentially curative total gastrectomy frequently experience weightloss, diarrhoea and abdominal symptoms. This malassimilation syndrome has been attributed to changed eating habits ${ }^{50-59}$, bacterial overgrowth ${ }^{42}$, rapid upper intestinal transit $^{42.44}$, primary ${ }^{60.61}$ or secondary pancreatic insufficiency ${ }^{62.64}$, deficiency of gastric lipase after total gastrectomy ${ }^{65}$, pancreatico-cibal asynchrony ${ }^{66-68}$, or other gastrointestinal motility disorders ${ }^{34,35,39,69}$.

Oro-coecal transit time in healthy persons is influenced by various factors including size and composition of gastric contents ${ }^{18}$, as well as volume of gastric secretion ${ }^{19}$, diet composition ${ }^{21-29}$, and proteolytic activity of the pancreas ${ }^{30}$. After total gastrectomy for gastric cancer tumour stage, type of surgical reconstruction, the time elapsed since operation and nutritional factors are of potential impact.

Studies on intestinal motility changes after curative total gastrectomy and their consequences are $\operatorname{rare}^{42}$. The aim of the present multicenter study was, therefore, to elucidate whether rapid oro-coecal transit influences symptoms, biochemical parameters, and nutrient assimilation controlling for some of the confounding variables mentioned above.

The patients of the present study had in general been operated on for early stage cancer and the selection of the patients to care in a rehabilitation centre remote from home made it probable that there was limited comorbidity. In all cases persisting or recurrent malignancy was excluded by thorough clinical investigation. Assessing oro-coecal transit time after total gastrectomy poses a problem. An $\mathrm{H}_{2}$ breath test with lactulose seemed not feasible, because this substance accelerates transit time in healthy persons ${ }^{2,3,13}$ and might even cause dumping problems after total gastrectomy. Radio-nuclear methods were not available in all participating hospitals. We therefore used a radiographically controlled $\mathrm{H}_{2}$-breath test with a standard meal in a modification described by Armbrecht et al ${ }^{4}$ to look for rapid oro-coecal transit and to simultaneously control for bacterial overgrowth of the small bowel. Rapid oro-coecal transit was defined as being faster than 75 minutes ${ }^{42}$. This value is lower than the lower normal limit for oro-coecal transit in healthy persons $s^{3,4,6 \cdot 12}$. The test, however, does not give absolute figures for transit times below 75 minutes, and also, in patients with bacterial overgrowth the transit time cannot be assessed. Patients with bacterial overgrowth were therefore excluded from the study.

After total gastrectomy, the frequency of an oro-coecal transit time below 75 minutes as assessed with this method has previously been described as $21.7 \%$. The frequency of an oro-coecal transit below 75 minutes described in this study $(36 \%)$, is probably falsely high, as 47 patients with small bowel bacterial overgrowth and normal oro-coecal transit time were left out of the analysis to exclude bacteria as a possible aetiopathogenic factor for alterations in symptoms, 
nutrient malassimilation, and medico-social functioning ${ }^{49}$. In 30 other patients there were technical problems with the second radiograph and oro-coecal transit time could not be measured precisely. These patients were not included in this study either.

On first sight it might be surprising that not all patients after total gastrectomy have a shortened oro-coecal transit time, since the anatomical oro-coecal distance is shortened. However, transit time after gastrectomy is not necessarily faster than in healthy controls $\mathrm{s}^{30-41}$.

The prevalence of symptoms of the patients was high. Bloating was significantly more frequent in patients with an oro-coecal transit time below 75 minutes. Colonic bacterial fermentation of malabsorbed carbohydrates with gas production is the probable explanation for this.

Although the overall symptom-score of the patients with a rapid OCTT was $55 \%$ higher than the score of the patients with normal OCTT, this difference was not significant. Since overall symptom intensity as well as the medico-social functioning were similar in both groups, it is not surprising that the employment status of the two study groups did not differ essentially.

Body mass index and weight development were nearly identical in patients with normal oro-coecal transit time and in patients with a transit faster than 75 minutes; also the energy intake of the two groups was comparable. This seems to be in contrast to a smaller previous study, which showed a negative correlation between weight loss and oro-coecal transit time. However, in contrast to the present study, in that study by Armbrecht et al ${ }^{42}$ oro-coecal transit times below 75 minutes were further specified. Three of the eleven patients analysed had an oro-coecal transit of less than 60 minutes and in one additional patient oro-coecal transit was faster than 50 minutes. Two of these four patients had by far the greatest weight loss of the whole study group.

Bowel habits were not different between the study groups. This is understandable, since a healthy colon is able to compensate for moderate malabsorption. Anamnestical data regarding bowel habits will therefore give little clue as to the presence or absence of rapid oro-coecal transit in patients after total gastrectomy.

Whereas most biochemical values did not differ between the studly groups, the chymotrypsin concentration of the faeces was significantly lower in patients with short oro-coecal transit, and faecal chymotrypsin output also tended to be lower. The most probable explanation is a decreased stimulation of the exocrine pancreas in patients with rapid oro-coecal transit compared to those with normal transit times.

Patients with rapid OCTT had a significantly greater fat malassimilation than those with normal OCTT. Two main factors seem to be responsible: at the first the spillover to the colon of considerable amounts of nutrient substrate, secondly the impaired intraluminal digestion of the substrate due to lack of lipolytic capacity. If 
the chymotrypsin concentrations and output measured in this study can be supposed to reflect exocrine pancreatic function, then the values obtained not only suggest a decreased pancreatic function (due to insufficient stimulation) but also a decreased intraluminal availability (due to pancreatico-cibal dyssynchrony).

The findings of the present study seem to explain why after total gastrectomy supplementation of pancreatic enzymes in its own has little effect on nutrient malassimilation (as recently indicated ${ }^{70}$ ). We suggest, therefore, that in patients with nutrient malassimilation and shortened OCTT after total gastrectomy pancreatic enzymes should be combined with measures prolonging small-intestinal transit. 


\section{References}

1. Corbett CL, Thomas S, Read NW, Hobson N, Bergman I, Holdsworth CD. Electrochemical detector for breath hydrogen determination: measurement of small bowel transit time in normal subjects and patients with the irritable bowel syndrome. Gut $1981 ; 22: 836-840$

2. Bond JH Jr, Levit MD, Prentiss R. Investigation of small bowel transit time in man utilizing pulmonary hydrogen $\left(\mathrm{H}_{2}\right)$ measurements. J Lab C in Med 1975;85;546-555

3. Korth H, Muller I, Erkenbrecht JF, Wienbeck M. Breath hydrogen as a vest for gastrointestinal transit. Hepatogastroenterology 1984;31:282-284

4. Armbrecht U, Jensen J, Eden $\mathrm{S}$, Stockbrügger RW. Assessment of Oro-coecal Transit Time by Means of a Hydrogen $\left(\mathrm{H}_{2}\right)$ Brealh Test As Compared with a Radiologic Control Method. Scand J Gastroenterol 1986;21:669-677

5. von der Ohe MR, Camilleri M. Measurement of small bowel and colonic transit: indications and methods. Mayo Clin Proc 1992;67:1169-1179

6. Argenyi ES, Soffer EE, Madsen MT, Berbaum KS, Walkner WO. Scintigraphic evaluation of small bowel transit in healthy subjects: inter- and intrasubject variability. Am J Gastroenterol 1995;90:938-942

7. Maurer AH, Krevsky B. Whole-gut transit scintigraphy in the evaluation of smallbowel and colon transit disorders. Semin Nucl Med 1995;25:326-338

8. Malagelada $J \mathbb{R}$, Robertson JS, Brown ML, Remington $M$, Duenes JA, Thomforde CM, Carryer PW. Intestinal Transit of Solid and Liquid Components of a Meal in Health. Gastroenterology 1984;87:1255-1263

9. Read NW, Al-Janabi MN. Holgate AM, Barber DC, Edwards CA. Simultaneous measurement of gastric emplying, small bowel residence and colonic filling of a solid meal by the use of the gamma camera. Gut 1986;27:300-308

10. Camilleri M, Colemont LJ, Phillips SSF, Brown ML, Thomforde GM, Chapman N, Zinsmeister AR. Human gastric emptying and colonic filling of solids characterized by a new method. An J Physiol 1989;257:284-290

11. Kerlin P. Byrnes O. Wong L. Radiolabelled unprocessed bran: Validation of a practical labelling technique and evaluation of gastrointestinal profiles in health. I Gastroenterol Hepatol 1989:4:119-126

12. Camilleri M, Zinsmeister AR, Greydanus MP, Brown ML, Proano M. Towards a less costly but accurate test of gastric emptying and small bowel transit. Dig Dis Sci $1991 ; 36: 609-615$

13. Miller MA, Parkman HP, Brown KL, Donahue DJ, Knight LC, Urbain J-L, Maurer AH, Fisher RS. The lactulose breath test is not a physjologic standard for orocecal transit: Lactulose delays gastric emptying and accelerates small bowel transit. Gastroenterology 1995; 108: A650

14. Piloto A. Franceschi M, Del Favero G, Fabrello R. Di Mario F, Valerio G. The effect of aging on oro-coecal transit time in normal subjects and patients with gallstone disease. Aging Clin Exp Res 1995;7:234-237 
15. Kupfer RM, Heppel M, Haggith JW, Bateman DN, Gastric emptying and small bowel transit rate in the elderly. J Am Geriatr Soc 1985;33:340-343

16. Wegener M, Borsch G, Schaffstein J, Luth I, Rickels R. Ricken D. Effect of aging on the gastrointestinal transit of a lactulose supplemented mixed solid-liquid meal in humans. Digestion 1988;39:40-46

17. Wald A, Van "Thiel DH, Hoechstetter L, Gavaler IS, Egler KM, Verm R, Scott L, Lester R: Gastrointestinal transit: The effect of the menstrual cycle. Gastroenterology 1981:80:1497-1500

18. Read NW, Cammack I, Edwards C, Holgate AM, Cann PA, Brown C. Is the transit time of a meal through the small intestine related to the rate at which it leaves the stomach? Gut $1982 ; 23: 824-828$

19. Armbrecht U, Dotevall $G$, Stockbrügger RW. The effect of gastric secretion on orocoecal transit time measured with the hydrogen (H2) breath test. $Z$ Gastroenterologie 1987;25:145-150

20. Mizumoto A, Sarr MG, DiMagno EP. Do pancreatic enzymes regulate oroileal transit in canine pancreatic insufficiency? Gastroenterology 1995; 108:A377

21. Richardson A, Delbridge AT, Brown NJ, Rumsey RD, Read NW. Short chain fatty acids in the terminal ileum accelerate stomach to caecum transit time in the tat. Gut $1991 ; 32: 266-269$

22. Ledeboer M, Masclee AA, Jansen JB, Lamers CB. Effect of equimolar amounts of long-chain triglycerides and medium-chain triglycerides on small-bowel transit time in humans. Jour Parenter Enteral Nutr 1995;19:5-8

23. Dreznik $Z$, Brocksmith D, Meininger TA, Soper $\mathbb{N J}$. Inhibitory effect of ileal olleate on postprandial motility of the upper gut. Am I Physiol 1990;26:458-463

24. Read NW, McFarlane A, Kinsman RI, Bates TE, Blackhall NW, Farrar GBJ, Hall JC, Moss G, Morris AP, O'Neill B, Welch I, Lee Y, Bloom SR. Effect of Infusion of Nutrient Solutions Into the Ileum on Gastointestinal Transit and Plasma Levels of Neurotensin and Enteroglucagon. Gastroenterology 1984;86:274-280

25. Holgate AM, Read NW. Effect of lleal Infusion of Intralipid on Gastrointestimal Transit, lleal Flow Rate, and Carbohydrate Absorption in Humans After Ingestion of a Liquid Meal. Gastroenterology 1985;88:1005-1011

26. Spiller RC, Trotman IF, Higgins BE, Ghatei MA, Grimble GK, Lee YC, Bloom SR, Misiewicz JJ, Silk DBA. The ileal brake - inhibition of jejunal motility after ileal fat perfusion in man. Gut 1984;25:365-374

27. Steed KP, Bohemen EK, Lamont GM, Evans DF, Wilson CG, Spiller RC. Proximal colonic responses and gastrointestinal transit after high and low fat meals. Dig Dis Sci $1993 ; 38: 1793-1800$

28. Cunningham KM, Daly J, Horowitz M, Read NW. Gastrointestimad adaptation to diets of differing fat composition in human volunteers. Gut 1991:32:483-486

29. Brown NI, Rumsey RD, Read NW. Gastrointestinal adaptation to enfanced small intestinal lipid exposure. Gut 1994;35:1409-1412

30. Farris JM, Ransom HK, Coller FA. Total Gastrectomy: Effects upon Nutrition and Hematopoisis. Surgery $1943 ; 13: 823-833$ 
31. Behrns KE, Sarr MG. Diagnosis and management of gastric emptying disorders. Adv Surg 1994:27:233-255

32. Thomas $H$, Heimbucher J, Fuchs KH, Freys SM, DeMeester TR, Peters JH, Bremner $\mathrm{CG}$. Thiede $\mathrm{A}$. The mode of Roux-en-Y reconstruction affects motility in the efferent limb. Arch Surg 1996;131:63-66

33. Gustavsson $\mathrm{S}$. Transporl of small bowel contents after interposition of an antiperistaltic jejunal segment in the rat. Eur Surg Res 1979;11:381-391

34. Faß J, Bares R, Hermsdorf V, Schumpelick V. Intestinal motility after jejunum interposition and Roux-Y construction - an animal experiment study. Langenbecks Arch Chir 1993:378:239-248

35. Faß\} J, Bares R, Staude M, Schumpelick V. Type of stomach replacement and intestinal motility after total gastrectomy. Leber Magen Darm 1993; 194:197-203

36. Pezzola $F$, Lantone $G$, Guerra $V$, Misciagna $G$, Prete F, Giorgio $I$, Lorusso D. Influence of the method of digestive tract reconstruction on gallstone development after total gastrectomy for gastric cancer. Am J Surg 1993;166:6-17

37. Stier A, Hölscher AH, Schwaiger M, Siewert JR. Jejunumpouch nach totaler Gastrektomie-Klinische und szintigraphische Untersuchungen zu Funktion und Befindlichkeit. Zentralbl Chir 1994; 119:838-844

38. Takahashi T, Yamamura T, Yokohama E, Kantoh M, Kusunoki M, Ishikawa Y, Utsunomiya J. Impaired contractile motility of the gallbladder after gastrectomy. Am J Gastroenterol 1986;81:672-677

39. van der Mijle HC, Kleibeuker JH, Limburg AJ, Bleichrodt. RP, Beekhuis H, van Schilfgarde R. Manometric and scintigraphic studies of the relation between motility disturbances in the Roux limb and the Roux-en-Y syndrome. Am J Surg $1993 ; 166: 11-17$

40. Woodward A, Sillin LF, Bortoff A. Migrating myoelectric complex and jejunal slow wave propagation after Roux-gastrectomy in dogs. Dig Dis Sci 1993;38:10731078

41. Pellegrini CA, Deveney CW, Patti MG, Lewin M, Way LW. Intestinal transit of food after lotal gastrectomy and Roux-Y esophagojejunosiomy. Am I Surg $1986: 151: 117-125$

42. Armbrecht U, Lundell L, Lindstedt G, Stockbrügger RW. Causes of malabsorption after tolal gastrectomy with Roux-en-Y reconstruction. Acta Chir Scand $1988 ; 154: 37-41$

43. Brägelmann R, Armbrecht U, Rosemeyer D, Schneider B, Zilly W, Stockbrugger RW. Nutrient malassimilation following total gastrectomy. Scand I Gastroenterol $1.996 ; 31: 26-33$

44. Bond $\sqrt{ }$, Levitt MD. Use of breath hydrogen $\left(\mathrm{H}_{2}\right)$ to quantitate small bowel transit time following partial gastrectomy. I Lab Clin Med 1977;90:30-36

45. Affleck JW, Aitken RCB, Hunter JAA, McGuire RJ, Roy CW. Rehabilitation Status: A Measure of Mediosocial Dysfunction. Lancet 1988;1:230-233

46. van de Kamer JH, ten Bokkel Huinink $H$, Weyers HA. Rapid method for the determination of fat in faeces. J Biol Chem 1949; 177:347-355 
47. Stockbrüger RW, Armbrecht U. Determination of Faecal Chymotrypsin Concentration and 72-Hour Faecal Chymotrypsin Output in the Detection of Pancreatic Steatorhoea. Scand J Gastroenterol 199:26:13-19

48. Brummer RJM, Armbrecht U, Bosaeus 1. Dotevall G. Stockbrügger RW. The Hydrogen $\left(\mathrm{H}_{2}\right)$ Breath test. Sampling Methods and the Influence of Dietary Fibre on Fasting Level. Scand J Gastroenterol 1985;20:1007-1013

49. Brägelmann R, Armbrecht U, Rosemeyer D, Schneider B. Zilly W, Stockbrügger RW. Small bowel bacterial overgrowth in patients atter cotal gastrectomy. Bur J Cin Invest 1997;27:409-16

50. Adams JF. The clinical and metabolic consequences of total gastrectomy. I. Morbidity, weight, and nutrition. Scand J Gastroenterol 1967:2:137-149

51. Roberts KE, Randall HT, Bane HN, Medwid A, Schwartz MK. Studies of the physiology of dumping syndrome. NY State J Med 1955;55:2897-2902

52. Sategna-Guidetti C, Bianco L. Malnutrition and malabsorption after total gastrectomy. A pathophysiologic approach. J Clin Gastroenterol 1989;11/5:518-524

53. Bradley EL, Isaacs J, Hersch $T$, Davidson ED, Milikan W. Nutritional consequences of total gastrectomy. Ann Surg 1975;182:415-429

54. Braga M, Zuliani W, Luciano F, Cristallo M, Carlo VD. Nutritional follow-up after total gastrectomy. Nutrition 1990;6:177-178

55. Cristallo $M$, Braga $M$, Agape $D$, Primignani $M$, Zuliani $W$, Vecchi $M$, Murone $M$, Sironi M, Di Carlo V, De Franchis R. Nutritional status, function of the small intestine and jejunal morphology after total gastrectomy for carcinona of the stomach. Surg Gyn Obst 1986:163:225 230

56. Crucitti F, Pacelli F, Doglietto GB, Bellantone R, Perri V, Bossola M, Tommasini O, Migglano G. Roux-en-Y Esophagojejunostomy in Reconstruction of the Alimentary Tract after Total Gastrectomy for Carcinoma of the Stomach. Nutrition $1990 ; 6: 261-263$

57. Delbrück H, Severin M. Lindenbeck U. Diätetische Aspekte und Befunde bei 227 gastrektomierten Magenkarzinompatienten. Akt Ernahr 1990;15:17-19

58. Nakane $Y$, Okumura $S$, Akehira K, Okamura S, Boku T, Okusa T, Tanaka K, Hioki K. Jejunal pouch reconstruction after rotal gastrectomy for cancer. A randomized controlled trial. Ann Surg 1995:222:27-25

59. Wechster JG. Ernährungsverhalten und Diät nach Gastrektomie. In: Der gastrektomierte Patient. U Armbrecht, RW Stockbrügger eds. Freiburg, S. Karger GmbH 1992:79-87

60. Friess $H$, Böhm J, Müller MW. Glasbrenner B, Riepl RL, Malfertheiner P, Buchler MW. Maldigestion after total gastrectomy is associated with pancreatic insutficiency. Am J Gastroenterol 1996;91:341-347

61. Büchler M, Malfertheiner P, Glasbrenner B, Beger HG. Rat exocrine pancreas function following total gastrectomy. Int J Pancreatol 1986;1:389-398

62. Gullo L, Costa L, Ventrucci M, Mattioli S, Vitti G, Labò G: Exocrine Pancreas Function after Total Gastrectomy. Scand J Gastroenterol 1979;14:401-407 
63. Köhler $H$, Schafmayer A, Peiper HJ. Die sekundäre exokrine Pankreasinsuffizienz nach Magenresektion. In Pankreas Diagnostik, Therapie. W Kozuschek, KJ Paquet. eds. Freiburg, S. Karger GmbH 1992:547-554

64. Büchler M, Malfertheiner P, Glasbrenner B, Friess H, Beger HG. Secondary Pancreatic Insufficiency Following Partial and Total Gastrectomy. Nutrition $1988: 4: 314-316$

65. Carriere $F$, Barrowman JA, Verger $R$, Laugier $R$. Secretion and Contribution to Lipolysis of Gastric and Pancreatic Lipases During a Test Meal in Humans. Gastroenterology 1993;105:876-888

66. Mackay C. Postgastrectomy steatorrhoea. Am J Surg 1970;120:324-328

67. Curran FT, Hill GL. Failure of nutritional recovery after total gastrectomy. Br J Surg 1990;77:1015-1017

68. Armbrecht U, Brägelmann R, Baumgart I, Stockbrügger RW. Fecal Chymotrypsin Output in Relation To Fecal Fat after Partial and Total Gastrectomy. Gastroenterology 1994; 106:A219

69. Miholic J, Meyer HD, Kotzerke J, Balks J, Aebert H, Jäne J, Weimann A, Pichlmayr R. Emptying of the Gastric Substitute After Total Gastrectomy: Jejunal Interposition versus Roux-en-Y. Ann Surg 1989;210:165-172

70. Brägelmann R, Armbrecht U, Rosemeyer D, Schneider B, Zilly W, Stockbrügger RW. The Effect of Pancreatic Enzyme Supplementation in Patients with Total Gastrectomy and Steatorrhea. Gastroenterology 1995108:A451 


\section{Chapter VII}

\section{Small Bowel Bacterial Overgrowth in Patients after Total Gastrectomy}

R Brägelmann, U Armbrecht, D Rosemeyer, B Schneider, W Zilly, RW Stockbrügger

Eur J Clin Invest 1997; 27:409-416 


\section{Abstract}

\section{Purpose}

To elucidate the consequences of small bowel bacterial overgrowth (SBBO) after total gastrectomy.

\section{Methods}

127 patients evaluated for SBBO with a radiographically controlled $\mathrm{H}_{2}$-breath-test (subgroup I, without $\mathrm{SBBO}, \mathrm{n}=80$; subgroup II, with $\mathrm{SBBO}, \mathrm{n}=47$ ) after potentially curative total gastrectomy for gastric malignancy were uniformly evaluated.

\section{Results}

Mean time since operation was significantly shorter in subgroup II than in subgroup I $((370$, confidence interval $=\mathrm{CI} 96-645$ vs. 687, CI 397-976) days; $\mathrm{p}<0.01)$. Controlling for this difference, there were no other significant differences in symptoms and signs between the subgroups except for the medico-social functioning measured with the Edinburgh Rehabilitation Status Scale (ERSS). The mean ERSS showed significantly better medico-social functioning in subgroup I than in subgroup II $(3.7 \mathrm{CI}(2.2-5.2)$ vs. $5.1 \mathrm{Cl}(3.0-7.0) ; \mathrm{p}<0.05)$.

\section{Conclusions}

After total gastrectomy, patients without SBBO did not significantly differ from patients with SBBO in most parameters. Medico-social functioning was significantly poorer in the latter. 


\section{Introduction}

Under normal conditions the human small bowel contains only a small number of bacteria. If more than $10^{5} \mathrm{CFU}$ per $\mathrm{ml}$ of anaerobic or facultative anaerobic bacteria are found in a small bowel aspirate, one speaks of bacterial overgrowth? Cultures of intestinal aspirates are the diagnostic "gold standard". Other diagnostic tests are based on breath-tests using miscellaneous substrates ${ }^{1.24}$.

There are a number of different etiological factors for small bowel bacterial overgrowth: Structural lesions altering motility ${ }^{1}$, functional motility disorders ${ }^{5.4}$, an excessive load of bacteria through fistulas ${ }^{3}$ or the resection of the ileo-coecal valve ${ }^{9}$, impaired gastric acid secretion ${ }^{10.11}$, immune deficiencies", exocrine pancreas insufficiency ${ }^{1}$, age ${ }^{12}$, undernutrition itself ${ }^{13}$, or any combination of those, are thought to be causative related to bacterial overgrowth.

Bacterial overgrowth can be asymptomatic ${ }^{7.14}$. The term small bowel bacterial overgrowth syndrome, however, describes a varying clinical picture consisting of intermittent diarrhoea, abdominal symptoms, steatorrhoea and malabsorption of vitamins and/or micronutrients, weight-loss. ${ }^{2.7 .15}$, and -in children- growth retardation ${ }^{16}$.

In patients after total gastrectomy, lack of gastric acid and motility disorders both are immanent, making bacterial overgrowth very frequent ${ }^{17}$. Patients after total gastrectomy often suffer from abdominal symptoms, malabsorption, steatorrhoea, and weight $\operatorname{loss}^{18}$. Possible factors influencing this post-gastrectomy syndrome are rapid upper intestinal transit ${ }^{19}$, the type of operation ${ }^{20-23}$, lack of gastric lipase ${ }^{24}$, primary or secondary exocrine pancreatic insufficiency ${ }^{2527}$, pancreatico-cibal dyssynchrony ${ }^{18,19,28-30}$, and possibly also small bowel bacterial overgrowth $(\mathrm{SBBO})^{4.9 .19 .31 .32}$.

The aim of this study was to elucidate whether in patients after totall gastrectomy there are any differences in symptoms, nutrient assimilation, and medico-social functioning between those with smatl bowel bacterial overgrowth and those without.

\section{Patients and methods}

During the period from May 1990 to January 1993, 196 consecutive patients following a potentially curative total gastrectomy for gastric malignancy were seen in a retrospective study at three German gastroenterological rehabilitation hospitals in Bad Kissingen, Bad Driburg, and Bad Brückenau. Of these, 14 patients were evaluated for the second time and in eight patients $(4.4 \%)$ a recurrence and/or metastasis was diagnosed shortly after admission. These patients were excluded from this study. The remaining 174 consecutive patients were evaluated in study. 


\section{Basic ewaluation}

After clinical and biochemical evaluation on admission, all patients were asked whether they suffered from the following abdominal symptoms: dyspepsia, bloating, early satiety, reflux, dysphagia, dumping, vomiting; also overall wellbeing was evaluated. Body mass was evaluated using the Quetelet index (weight/height; normal range (20.0 to 25.0$\left.) \mathrm{Kg} / \mathrm{m}^{2}\right)$.

\section{Medico-social functioning}

In order to assess medica-social functioning the Edinburgh Rehabilitation Status Scale (ERSS) ${ }^{33}$ was applied on admission and the employment status was noted. The ERSS scale ranges from 0 to 28 points, with higher points indicating a poorer medico-social functioning. The scale measures the dimensions of medico-social performance in four different subscales: Independence, activity, social integration, and effects of symptoms on lifestyle. These subscales are summed up in the sumscore. This was done in all patients.

\section{Controlled diet period}

Patients who were on pancreatic enzyme supplementation at the time of hospital admission were asked to discontinue this. Thereafter, all patients were put on a standardised diet for five days. The controlled diet period of five days started three to five days following admission. The diet was composed of $48 \%$ fat, $17 \%$ protein, and $35 \%$ carbohydrates, respectively, and was not limited quantitatively. However, individual nutritional intake was quantified during the controlled diet period at every meal by an attending dietician and summarised each day. During the period of controlled diet abdominal complaints, faecal frequency and faecal consistency were scored daily according to a questionnaire and a five-day-score of each parameter was reported.

\section{Fat malassimilation}

During the last three days of the controlled diet period faecal mass and faecal fat output were assessed. The latter according to the method of van de $\mathrm{Kamer}^{34}$. Fat assimilation was calculated as the proportion of fat excreted compared with intake.

\section{Endoscopy}

An upper endoscopy was performed on each patient, except when it had been performed during the previous two months. In these cases the endoscopic diagnosis from the last examination was noted. 


\section{$\mathbf{H}_{2}$-breath test with radiopaque markers}

The frequency of rapid upper intestinal transit and small bowel bacterial overgrowth were evaluated simultaneously using a modification of the $\mathrm{H}_{2}$-breath test described by Armbrecht ef al. ${ }^{4}$ : Medical records were scrutinised to ensure that no antimicrobial treatment had been given during the previous 2 weeks. After a low-fibre diet during the day before the test and an overnight fast ${ }^{35}$, end-expiratory $\mathrm{H}_{2}$-concentrations were analysed serially every 15 minutes, starting 15 minutes prior to the breakfast, the composition of which is shown in Table VII.1.

Table VII.1

Composition of the standard test meal

\begin{tabular}{llcc} 
Water & 150 & $\mathrm{mi}$ \\
Porridge made from & water & 200 & $\mathrm{ml}$ \\
& milk & 50 & $\mathrm{ml}$ \\
& rolled oats & 36 & $\mathrm{~g}$ \\
White bread & & 50 & $\mathrm{~g}$ \\
Margarine & 10 & $\mathrm{~g}$ \\
Cheese (16\% fat) & 13 & $\mathrm{~g}$ \\
Smoked medwurst & 12 & $\mathrm{~g}$ \\
Total energy content & 2.0 & $\mathrm{MJ}$ \\
Energy contribution from carbohydrate & 39 & $\%$ \\
lo radiopaque markers & & \\
\hline
\end{tabular}

Ten radiopaque markers $(6.0 \times 1.8 \mathrm{~mm})$ were added to the test meal to evaluate orocoecal transit time. $\mathrm{H}_{2}$-concentrations were measured with a GMI Exhaled $\mathrm{H}_{2}$ Monitor (GMI Medical Ltd., Inchinnan Estate, Renfrew, Scotland). Samples were taken by direct insufflation via a $\mathrm{Y}$-piece with flow reduction ${ }^{35}$. Samples were taken at each time point, and the arithmetic mean of these two measurements was used for evaluation. 75 minutes after the beginning of the breakfast a plain abdominal $x$ ray was taken to diagnose oro-coecal transit shorter than 75 minutes. In patients with an oro-coecal transit time below 75 minutes it is not possible to diagnose bacterial overgrowth with a breath test, because rise in $\mathrm{H}_{2}$-concentration can be due to oral flora or movement of ileal contents into the coecum by the gastro-intestinocolic reflex ${ }^{4.36}$. When there was a $100 \%$ rise above base line values in breath $\mathrm{H}_{2}$-concentration a second radiograph was taken to differentiate between upper intestinal bacterial overgrowth or transit of the test meal into the colon. Figure VII.1 exemplifies a normal test and a test showing small bowel bacterial overgrowth. 


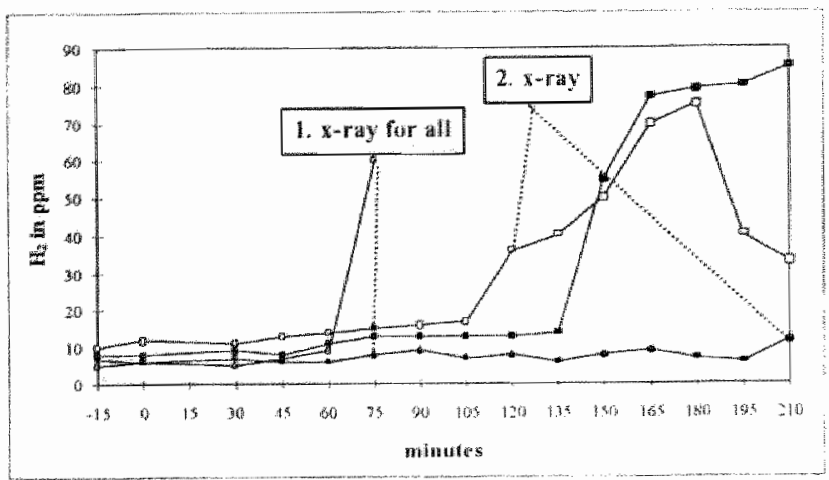

Figure VII.1 Meisurements of oro-coecal transit time in patients after total gastrectomy with nornal or with rapid oro-coecal transit (OCTT $<75$ minutes). Examples of $\mathrm{H}_{2}-$ breath tests with a test breakfast as used in this study. The line with the filled circles denotes a patient without bacterial overgrowth and an oro-coecal transit time exceeding 210 minutes. The line with the black squares denotes a parient without bacterial owergrowth in whom markers were identified in the ascending colon at 150 minutes. The line with the white squares denotes a patient with bacterial overgrowth. At 120 minutes there is a rise in $\mathrm{H}_{2}$-concentration, but markers were identified in the small intestine; the OCTT could therefore not be measured. The line with the white circles denotes a patient with an oro-coecal transit time below 75 minutes as the $\mathrm{H}_{2}$-values were already rising and radiopaque narkers were identified in the ascending colon at 75 mimutes.

\section{Statistics}

Statistical calculations included the $\chi^{2}$-tests. General factorial ANOVA-models and multiple logistic regression models were used to control for difference in time since operation. A p-value of 0.05 was considered to be significant ${ }^{37}$.

\section{Results}

The $\mathrm{H}_{2}$-breath test was not evaluable for the diagnosis of bacteriall overgrowth in 35 patients, because the oro-coecal transit time was shorter than 75 minutes, and in nine patients, because of technical difficulties and/or prior antibiotic treatment. Three patients were classified as $\mathrm{H}_{2}$-nonproducers. These 47 patients were excluded from further analysis. The remaining 127 patients $(\mathrm{f}=47, \mathrm{~m}=80$; mean age 56.9 $(95 \%$ confidence interval $=\mathrm{CI}(55.1$ to 58.7$))$ years $)$ after potentially curative total gastrectomy for gastric malignancy 573 days earlier (mean; CI 364 to 782) were evaluated. Patients without SBBO $(n=80,63 \%)$ were compared with patients with SBBO $(n=47,37 \%)$.

In patients with small bowel bacterial overgrowth the time period between 
operation and hospital admission was significantly shorter (370 (96-645) days, Cl) than in patients without bacterial overgrowth (687 (397-976) days, Cl) (Table VII.2). Controlling for the difference in time span since operation, there were no differences between the two study groups regarding gender, age, tumour stage and type of operation and/or reconstruction.

Table VII.2 Gender, age, time since operation, tumour stage, and type of operation in 127 patients without or with small bowel bacterial overgrowth (SBBO)

\begin{tabular}{|c|c|c|c|c|}
\hline & no SBBO $(n=80)$ & & $\operatorname{SBBO}(n=47)$ & \\
\hline \multicolumn{5}{|l|}{ Gender } \\
\hline Male & 55 & & 25 & \\
\hline Female & 25 & & 22 & \\
\hline Age (years)" & $55.7(53.4-58.0)$ & & $59.0(56.1-61.8)$ & \\
\hline Time past operation (days) & $687(397-976)^{* *}$ & & $370(96-645)^{* *}$ & \\
\hline \multicolumn{5}{|l|}{ Tumour stage (UICC) } \\
\hline 0 & 2 & & 2 & \\
\hline IA & 23 & & 10 & \\
\hline IB & 18 & & 5 & \\
\hline II & 9 & & 10 & \\
\hline IIIA & 11 & & 6 & \\
\hline IIIB & 2 & & 4 & \\
\hline IV & 2 & & 1 & \\
\hline Iymphomas & 13 & & 9 & \\
\hline \multicolumn{5}{|l|}{ Type of operation } \\
\hline Roux-en-Y without pouch & 39 & $49 \%$ & 21 & $45 \%$ \\
\hline Roux-en-Y with pouch & 13 & $16 \%$ & 10 & $21 \%$ \\
\hline small bowel interposition & 9 & $11 \%$ & 10 & $21 \%$ \\
\hline unknown & 19 & $24 \%$ & 6 & $13 \%$ \\
\hline
\end{tabular}

"means and confidence intervals; ${ }^{* *} \mathrm{p}=0.0039$

Mean basic haematological and biochemical values were in the normal range and did not differ significantly between the study groups (Table VII.3). The frequencies of pathological haematological or biochemical values were similar in both groups for all parameters. Mean ferritin values were lower in patients with bacterial overgrowth compared with patients without bacterial overgrowth and positive faecal occult blood tests were more frequent in patients with bacterial 
overgrowth compared with patients without bacterial overgrowth. Neither of these differences, however ${ }_{\text {; }}$ was significant.

Table VII.3 Hatmatological and biochemical data on hospital admission in 127 patients without or with small bowel bacterial overgrowth (SBBO)

\begin{tabular}{|c|c|c|c|c|c|c|c|}
\hline & \multirow[t]{2}{*}{ normal trange } & \multicolumn{3}{|c|}{ no SBPO } & \multicolumn{3}{|c|}{ SWBO } \\
\hline & & $n$ & mean & CI & n & mean & CI \\
\hline 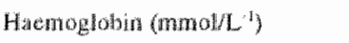 & $8.2+11.0$ & 76 & 8.4 & $8.2-8.7$ & 47 & 8.3 & 8.0 .8 .6 \\
\hline 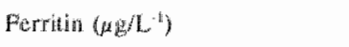 & $20-400$ & 74 & 106 & $54 \div 58$ & 46 & 72 & 52.92 \\
\hline Albumin $\left(\mathrm{EL}^{-1}\right)$ & $35.2-50.4$ & 75 & 44 & $43-46$ & 46 & 42 & $40-4.4$ \\
\hline Calcum (mmad/L') & $2.20-2.50$ & 75 & 2.40 & $2.34-2.47$ & 46 & 2.42 & $2.35-2.48$ \\
\hline Chymourypsitum oupue (U/72hrs) & $50434769^{\circ}$ & 25 & 3441 & $2196-4686$ & 18 & 3864 & $3132-4596$ \\
\hline POBT & & & $2 / 77$ & $2.6 \%$ & & $4 / 47$ & 8.5 \\
\hline
\end{tabular}

Cl denotes confidence interval; " according to Stockbrügger et al ${ }^{\text {st; }}$; faecall occult blood test (at least 1 of 3 slides positive); chymotrypsin output was assessed in 43 patients only

Symptoms were reported by $83 \%$ of the patients. Bloating, dyspepsia, and early satiety were the most frequent. The greatest difference between the patients with bacterial overgrowth and those without bacterial overgrowth was more bloating in the former ( $71 \%$ vs $53 \%)$. This difference, however, was not significant $(\mathrm{p}=0.25)$. The symptom score was low in both study groups. (Table VII.4).

Table VII.4 Frequency and severity of symptoms on admission in 127 patients without or with small bowel bacterial overgrowth (SBBO)

\begin{tabular}{lcccccc}
\hline & \multicolumn{2}{c}{ no SBBO } & \multicolumn{2}{c}{ SBBO } \\
& number & $\%$ & number & $\%$ & \\
\hline & 80 & & 47 & & \\
Bloating" & $16 / 30$ & 53 & $12 / 17$ & 71 & \\
Dyspepsiat & 45 & 56 & 32 & 68 & \\
Early saticty & 42 & 53 & 25 & 53 & \\
Reflux & 21 & 26 & 12 & 26 & \\
Dysphagiat & 15 & 19 & 9 & 19 & \\
Postprandial vomiting & 11 & 14 & 5 & 11 & \\
Any symptom & 65 & 81 & 41 & 87 & \\
& & mean & $\mathrm{Cl}$ & & mean & Cl \\
Symptomscore & 74 & 0.567 & $0.392-0.743$ & 46 & 0.540 & $0.354-0.726$ \\
\hline
\end{tabular}

"bloating was asked in 47 patients only; " scale from 0.000 to 3.000 ; Cl denotes confidence interval. 
There were no significant differences between patients with and without small bowel bacterial overgrowth regarding the employment status or the Karnovsky index. The Edinburgh Rehabilitation Status Scale-score (ERSS) was significantly higher (38\%) in patients with bacterial overgrowth than in those without (Table VII.5).

There was no difference between the study groups regarding the frequency of upper intestinal endoscopic examination, the fundings at endoscopic examination, and the number of pathological upper intestinal endoscopic examinations.

Table VII.5 Employment status, Karnovsky index, and Edinburgh Rehabilitation Status Scale (ERSS) on admission in 127 patients without or with small bowel bacterial overgrowth (SBBO)

\begin{tabular}{|c|c|c|c|c|c|c|}
\hline & \multicolumn{2}{|c|}{ no $\mathrm{SBBO}$} & \multicolumn{4}{|c|}{$\mathrm{SBBO}$} \\
\hline & number & $\%$ & & number & $\%$ & \\
\hline Employment status & 80 & & & 47 & & \\
\hline working & 10 & 12.5 & & 4 & 8.5 & \\
\hline due to ill health & 22 & 27.5 & & 11 & 23.4 & \\
\hline temporary retirement due to ill health & 1 & 1.3 & & 4 & 8.5 & \\
\hline early retirement & 8 & 10.0 & & 1 & 2.1 & \\
\hline retimement & 22 & 27.5 & & 19 & 40.4 & \\
\hline unemployed & 17 & 21.3 & & 8 & 17.0 & \\
\hline ratio working/potentially working population & $10 / 41$ & 24 & & $4 / 20$ & 20 & \\
\hline Karnovsky index* & 84 & 80 & -89 & 80 & 75 & -86 \\
\hline ERSS $^{*}(0$ to 28 , best to worst) & $3.7^{* * *}$ & 2.2 & -5.2 & $5.1^{* *}$ & 3.0 & -7.0 \\
\hline
\end{tabular}

"means and confidence intervals: " $p=0.038$

In the whole group of patients the mean body mass index on admission was 22.1 $\mathrm{kg} / \mathrm{m}^{2}$ (CI 21.5 to 22.7 ). The patients had lost a mean of 6.4 (Cl 4.1 to 6.7 ) \% of their weight since the operation. Mean kilojoule intake per kilogram body weight and day was 156 (CI 148 to 164) in all patients with a mean fat intake of 117 (CI 112 to 121) gram per day during the controlled diet period. There was no significant difference in any of these parameters between the two study groups (Table VII.6). 
Table VII.6

Weight development and calorie intake in patients without or with small bowel bacterial overgrowth (SBBO)

\begin{tabular}{lccccccc}
\hline & \multicolumn{3}{c}{ no SBBO } & \multicolumn{4}{c}{ SBBO } \\
& $\mathrm{n}$ & mean & $\mathrm{Cl}$ & $\mathrm{n}$ & mean & $\mathrm{CI}$ \\
\hline BMI $\left(\mathrm{kg} \mathrm{m}^{2}\right)$ & 78 & 22.1 & $21.4-22.8$ & 47 & 22.0 & $21.1-23.0$ \\
Weight loss $(\%)^{*}$ & 78 & 5.6 & $2.4-8.8$ & 47 & 7.6 & $4.4-10.7$ \\
Caloric intake $(\mathrm{kJ} / \mathrm{day})^{* *}$ & 73 & 9669 & $9180-10163$ & 44 & 9397 & $8837-9954$ \\
Caloric intake $(\mathrm{kJ} / \mathrm{kg}$ body weight and day) & 70 & 154 & $144-164$ & 43 & 158 & $145-172$ \\
Fat intake $(\mathrm{g} / \mathrm{day})^{* *}$ & 73 & 118 & $112-124$ & 44 & 115 & $108-121$ \\
\hline
\end{tabular}

$\mathrm{Cl}$ denotes confidence interval; "denotes weight loss since operation in \%; " during a five-dayperiod

Bowel habits and faecal mass were not different between the two groups. Compared with patients without small bowel bacterial overgrowth, patients with small bowel bacterial overgrowth had a higher mean faecal fat excretion and fat malassimilation, but theses differences were not statistically significant (Table VII.7).

Table VII.7

Bowel habits, faecal mass, faecal fat excretion, and fat malassimilation in 127 patients without or with small bowel bacterial overgrowth (SBBO)

\begin{tabular}{lccccc}
\hline & \multicolumn{2}{c}{ no SBBO } & \multicolumn{3}{c}{ SBBO } \\
& mean & CI & mean & CI \\
\hline number & 80 & & 47 & \\
Fadecal consistency" (5-day-period) & 1.2 & $1.1-1.4$ & 1.3 & \\
number & 71 & & 45 & $1.2-1.7$ \\
Faecall frequency per day (5-day-period) & 1.6 & $1.4-1.8$ & 1.5 & \\
number & 66 & & 43 & \\
Fatecall mass (g/d, 3-day-period) & 249 & $205-293$ & 233 & $1.1-1.7$ \\
number & 76 & & 44 & \\
Fatecal tiat excretion (g/d, 3-day-period) & 14.8 & $11.2-18.5$ & 19.3 & $13.1-25.6$ \\
number & 73 & & 41 & \\
Fat matassimilation (\% of fat intake, 3-day-period) & 12.2 & $9.5-15.0$ & 17.2 & $12.0-22.3$ \\
\hline
\end{tabular}

$\mathrm{Cl}$ denotes confidence interval; " faecal consistency is ranked: $0=$ no faeces, 1 =normally formed, $2=$ soft, 3 = watery darrhoed; scale from 0.0 io 3.0; " one centre reported no faecal mass 


\section{Discussion}

After gastrectomy, the combination of impaired gastric acid secretion and the altered gastric and intestinal motility facilitate bacterial overgrowth ${ }^{2.17}$. Bacterial overgrowth, however, can be asymptomatic. In patients with pernicious anaemia bacterial overgrowth with gram-negative and gram-positive bacteria is common, but the bacterial overgrowth syndrome is rare ${ }^{14}$.

The frequency of a bacterial overgrowth syndrome after total gastrectomy is not known. The small bowel bacterial overgrowth syndrome and the post-gastrectomy syndrome have many clinical and biochemical features in common. It is therefore tempting to suspect that some symptoms and clinical signs after total gastrectomy could be caused by bacterial overgrowth of the small intestine $e^{2,7.19,31,32}$.

In this multicentre study of patients after a potentially curative total gastrectomy we evaluated patients with and without small bowel bacterial overgrowth regarding subjective symptoms and objective signs of nutrient malassimilation. Our patient population had in general been operated on for early tumour stages. The selection of our patients for care in a rehabilitation centre also made it probable that there currently was little comorbidity and excluded cancer recurrence or other disease. Cultures of duodenal or jejunal aspirates are the "gold standard" in the diagnosis of bacterial overgrowth. However, they have shortcomings. Distal small bowel bacterial overgrowth and focal overgrowth in post-operative loops may be out of reach for the endoscope or another suction device and could therefore be missed on diagnosis. Furthermore, rapid transit of food to the bacteria-containing lower gut can cause symptoms very similar to the small bowel bacterial overgrowth syndrome ${ }^{6}$. Using lactulose or glucose as a substrate for a breath test might possibly have given false values, because both substrates accelerate small bowel transi $^{39-41}$; especially in patients after total gastrectomy. For this reason we used an $\mathrm{H}_{2}$-breath test to diagnose bacterial overgrowth of the small bowel in a modification described by Armbrecht et al. ${ }^{35.36,42}$, which controls for fastened oro-coecal transit. This modified $\mathrm{H}_{2}$-breath test has been shown to be sufficiently sensitive and specific in the diagnosis of upper gastrointestinal bacterial overgrowth in the operated and non-operated gastrointestinal tract. ${ }^{4}$. This test, however, is not applicable in patients who have an oro-coecal transit time below 75 minutes. Rise in $\mathrm{H}_{2}$-concentration in breath during the first 90 minutes can be due to oral flora or movement of ileal contents into the coecum by the gastro-intestino-colic reflex.3. This is why we had to exclude the patients with rapid small bowel transit from further analysis.

In our patients small bowel bacterial overgrowth was diagnosed in $37 \%$. The data regarding the frequency of small bowel bacterial overgrowth after total or partial gastrectomy are scarce and vary. Lock found bacterial overgrowth in 35 of 38 $(92 \%)$ patients after total gastroscopy ${ }^{17}$. However, he examined patients referred 
for endoscopy and a selection bias is possible. Bradley cultured anaerobes in all ten patients with total gastrectomy who he examined ${ }^{43}$. In patients with an Billroth II resection faecal flora was found in nine out of ten patients in gastric juice ${ }^{36}$. Bjømeklett studied 22 patients after a Billroth II resection, all of whom had small bowel bacterial overgrowth. However, so did half of the healthy controls ${ }^{44}$. Drasar assessed 43 patients with a partial gastrectomy and found small bowel bacterial overgrowth in 13 of them $(30 \%)^{4 s}$. In the gastric juice of patients with achlorhydria Armbrecht found faecal flora in $60 \%$ of the patients ${ }^{4}$ and Stockbrügger reported faecal flora in duodenal biopsies in eight of 19 patients with pernicious anaemia ${ }^{14}$.

In our study population, the time period since operation was shorter in patients with bacterial overgrowth than in those patients without bacterial overgrowth. The reason for this difference is not obvious. Earlier admission after operation to the rehabilitation hospital could be the result of complaints or dysfunctioning motivating patients to request care. However, the symptomatology in patients with SBBO was only marginally more severe than in patients without.

Symptoms were reported by the patients in both groups without any significant differences regarding the frequency and the severity of the symptoms. There was a trend for bloating to be more frequent in the patients with bacterial overgrowth. It might be that the number of patients questioned for bloating in our study was insufficient to demonstrate a difference.

There were no essential differences between patients with and patients without bacterial overgrowth in biochemical and haematological parameters. After total gastrectomy, the development of iron deficiency correlates positively with time ${ }^{18,46}$. It has been suggested by some authors that gastric surgery impairs iron absorption $^{47}$, while others could not find any difference in absorption ${ }^{48,49}$. Bacterial overgrowth can also cause gastro-intestinal bleeding resulting in iron deficiency ${ }^{50}$. In this study, controlling for the difference in time since operation, bacterial overgrowth was associated with a trend to lower ferritin values and/or a higher frequency of positive faecal occult blood tests.

Weight, weight development since operation, bowel habits and fat malassimilation were not significantly different between the study groups. Although patients with bacterial overgrowth scored worse in all parameters, especially those regarding fat assimilation, the confidence intervals overlapped extensively.

Considering the similarities in all the basic somatic parameters, it comes as no surprise that the Karnovsky-index between the groups did not differ.

On the Edinburgh Rehabilitation Status Scale the total group of patients scored low, which corresponds to a "high degree of medico-social functioning" ${ }^{33}$. This fact may be a result of the patient selection, as our patients had to be able to travel to the respective rehabilitation centres and to stay away from home for at least four weeks. However, patients with small bowel bacterial overgrowth had a significantly worse ERSS-score than patients without bacterial overgrowth. As mentioned above, 
a possible explanation for this phenomenon as well as for the shorter time span between operation and hospital admission, might be the integral effect of the negative trends seen in some of the post-operative data.

Therapy of post-surgical bacterial overgrowth is overshadowed by the risk of recurrence. Cyclic antibiotic treatments ${ }^{2.51}$, prokinetics ${ }^{52}$, $\operatorname{diet}^{53}$, probiotics ${ }^{54}$, and surgery 9 are possible therapeutic measures with varying success. None of the patients in the present study population had to receive antibiotic treatment during the actual sojorn. In conclusion, in the studied patients after total gastrectomy of this investigation the subgroup with small bowel bacterial overgrowth and the subgroup without bacterial overgrowth did not essentially differ in such parameters, symptoms, and signs, which are normally associated with bacterial overgrowth. The notion that a bacterial overgrowth syndrome is not a necessary consequence of extended gastric resection is also supported by other authors ${ }^{7,45,55}$. 


\section{References}

1. Toskes PP, Donaldson RM. Enteric Bacterial Flora and Bacterial Owergrowth Syndrom. In: Sleisinger $\mathrm{MH}$, Fordtran IS, eds. Gastrointestinal disease: pathophysiology, diagnosis, management. Philadelphia: WB Saunders, 1993:1106 18

2. Ellen Li. Bacterial Overgrowth. In: Yamada T ed, Textbook of Gastroenterology, 2nd edition, Philadelphia: Lippincott Company, 1995:1673-80

3. Corazza GR, Menozzi MG, Stocchi $A$, Rasciti $L$, Varia $D$, Lecchini $R$, Avanzini $P$, Chezzi C. Gasbarrini $G$. The diagnosis of small bowel bacterial overgrowth. Reliability of jejunal culture and inadequecy of breath hydrogen testing. Gastroenterology 1990;98:302-309

4. Armbrech U, Eden S, Seeberg S, Stockbrugger RW. The Value of the Hydrogen (H2) Breath Test for the Diagnosis of Bacterial Overgrowth in Gastric Achlohydria. Hepato-gastroenterol $1987 ; 34: 219-222$

5. Goldstein F, Wirts CW, Kowlessar OD. Diabetic diarmea and steatorrhea: microbiologiy and clinical observations. Ann Intern Med 1970;72:215-218

6. Vantrappen G, Janssens $J$. Coremans G, Jian R. Gastrointestinal motility disorders. Dig Dis Sci 1986;31:5S-25S

7. Husebye E. Gastrointestinal motility disorders and bacterial overgrowth. I Int Med $1995 ; 237: 419-427$

8. Atwater IS, Butt HR, Priestly JT. Gastrojejunocolic fistulae with special reference to associated nutritional deficiencies and certain surgical aspects. Ann Surg $1943: 117: 414-419$

9. Griffin WO Jr, Richardson JD, Medley ES. Prevention of small bowel contamination by illeocecal valve. South Med J 1971;64:1056-1058

10. Drasar BS, Shiner M, McLeod GM. Studies on the intestinal flora. I. The bacterial flora of the gastrointestinal tract in healthy and achlorhydric persons. Gastroenterology 1969:56:71-79

11. Stockbrügger RW, Cotton PB, Eugenides $N$, Bartholomew BA, Hill MJ, Walters $C L$. Intragastric nitrites, nitrosamimes, and bacterial overgrowth during cimetidine treatment. Gut 1982;23:1048-1054

12. Roberts $\mathrm{SH}$, Janes $\mathrm{O}$, Jarvis EH. Bacterial contamination of the small intestine is an important cause of occult malabsorption in the elderly. Lancet 1977;2:1193-1195

13. King CE. Toskes PP. Small intestinal bacterial overgrowth. Gastroenterology $1979 ; 76: 1035-55$

14. Stockbrügger RW, Armbrecht U, Rode JW, Teall AJ, Oberholzer VG, Croker JR, Cotton PB. The Bacterial Overgrowth Syndrome is Uncommon in Pernicious Anaemia: Results of a Follow-up Study. Microbial Ecology in Health and Disease $1990 ; 3: 209-215$

15. Toskes PP. Bacterial Overgrowth of the Gastrointestinal Tract. In: Stollerman GH, ed. Advances in Internal medicine. St. Louis: Mosby Year Book. 1993;38:387-407. 
16. Khin-Maung U, Bolin TD, Ducombe VM, Myo Khin, Nyunt-Nyunt Wai, Pereira SP, Linklater IM. Epidemiology of small bowel bacterial overgrowth and rice carbohydrate malabsorption in Burmese (Myanmar) village children. Am I Trop Med Hyg $1992 ; 47: 298-304$.

17. Lock G, Hollerbach S, Linde HJ, Vogt W, Andus T, Schölmerich J, Holstege A. Bacterial overgrowth after gastric surgery: Comparison of endoscopic aspiration and glucose $\mathrm{H}_{2}$-breath test. Gastroenterology $1995 ; 110 ; \mathrm{A} 343$

18. Brägelmann R, Armbrecht U, Rosemeyer D, Schneider B, Zilly W, Stockbrügger RW. Nutrient malassimilation following total gastrectomy. Scand d Gastroenterol 1996;31:26-33.

19. Armbrecht U, Lundell L, Lindstedt G, Stockbrügger RW. Causes of malabsorption after total gastrectomy with Roux-en-Y reconstruction. Acta Chir Scand $1988 ; 154: 37-41$

20. Fass J, Bares R, Hermsdorf V, Schumpelick V. Intestinal morility after jejunum interposition and Roux-Y construction - an animal experiment study. Langenbecks Arch Chir 1993; 378:239-248

21. van der Mijle HC, Kleibeuker JH, Limburg AJ, Bleichrodt RP, Beekhuis $H$, van Schilfgarde R. Manometric and scintigraphic studies of the relation between motility disturbances in the Roux limb and the Roux-en-Y syndrome. Am I Surg $1993 ; 166: 11-17$.

22. Woodward A, Sillin Lf, Bortoff A. Migrating myoelectric complex and jejunal slow-wave propagation after Roux-gastrectomy in dogs. Dig Dis Sci 1993;38: 10731078

23. Miholic J, Meyer HD, Kotzerke J, Balks J, Aebert H, Jäne J, Weimann A, Pichlmayr R. Emptying of the Gastric Substitute After Total Gastrectomy: Jejunal Interposition versus Roux-en-Y. Ann Surg 1989;210:165-172

24. Carriere F, Barrowman JA, Verger R. Laugier R. Secretion and Contribution to Lipolysis of Gastric and Pancreatic Lipases During a Test Meal in Humans. Gastroenterology 1993; 105:876-888

25. Friess H, Böhm J, Malfertheiner P. Glasbrenner B, Muller M, Hotbader B, Riepl RL, Büchler MW. Exokrine Pankreasinsuffizienz nach Gastrektomie: Eine primäre Funktionsstörung. Chirurgische Gastoenterologie 1994;10:324-330

26. Gullo L, Costa L, Ventrucci M, Mattioli S, Vitti G, Labó G. Exocrine Pancreas Function after Total Gastrectomy. Scand $\rfloor$ Gastroent 1979;14:401-407

27. Büchler $M$, Malfertheiner $P$, Glasbrenner $B$, Friess $H$, Beger $H G$. Secondary Pancreatic Insufficiency Following Partial and Total Gastrectomy. Nutrition 4:314316

28. Mackay C. Postgastrectomy steatornea. Am 』Surg 1970; 120:324-328

29. Curran FT, Hill GL. Failure of nutritional recovery after total gastrectomy. Br J Surg 1990;77:1015-1017

30. Tabaqchati, S. The Pathophysiological Role of Small Intestinal Bacterial Flora.

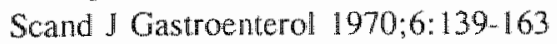


31. Cristallo $M$, Braga $M$, Agape D, Primignani $M$, Zuliani $W$, Vecchi $M$, Murone $M$, Sironi M, Di Carlo V, De Franchis R. Nutritional status, function of the small intestine and jejunal morphology after total gastrectomy for carcinoma of the stomach. Surgery, Gynecology, and Obstetrics 1986;163:225-230

32. Olbe L, Lundell L. Intestianl Function after Total Gastrectomy and Possible Consequences of Gastric Replacement. World J Surg 1987;11:713-719

33. Affleck $5 W$, Aitken RCB, Hunter IAA, McGuire RJ, Roy CW. Rehabilitation Status: A Measure of Mediosocial Dysfunction. Lancet 1988;1:230-233

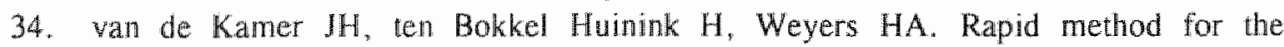
determination of fat in faeces. J Biol Chem 1949;177:347-355

35. Brummer RJM, Armbrecht $U$, Bosaeus I, Dotevall $G$, Stockbrügger RW. The Hydrogen $\left(\mathrm{H}_{2}\right)$ Breath test. Sampling Methods and the Influence of Dietary Fibre on Fasting Level. Scand J Gastroenterol 1985;20:1007-1013

36. Armbrecht U, Bosaeus I, Gillberg R, Seeberg S, Stockbrügger R. Hydrogen $\left(\mathrm{H}_{2}\right)$ Breath Test and Gastric Bacteria in Acid-Secreting Subjects and in Achlorhydric and Postgastrectomy Patients before and after Antimicrobial Treatment. Scand J Gastroenterol 1985;20:805-813

37. Lindeman RH, Merenda PF, Gold RZ. Introduction to Bivariate and Multivariate Analysis, Scott, Foresman and Company. London, 1980.

38. Stockbrügger RW, Armbrecht U. Determination of Faecal Chymotrypsin Concentration and 72- Hour Faecal Chymotrypsin Output in the Detection of Pancreatic Steatorrhea. Scand J Gastroenterol 1991;188:13-19

39. Lembcke, B. Current Role of Breath Tests in Gastroenterology. Z Gastroenterol 1996; 4:46-53

40. Bond $\mathrm{JH} \mathrm{Jr}$, Levitt MD, Prentiss R. Investigation of small bowel transit time in man utilizing pulmonary hydrogen $\left(\mathrm{H}_{2}\right)$ measurements. J Lab Clin Med. 1975;85:546555

41. Read NW, Cammack J, Edwards C, Holgate AM, Cann PA, Brown C. Is the transit time of a meal through the small intestine relared to the rate at which it leaves the stomach? Gut $1982 ; 23: 824-828$

42. Armbrecht U, Jensen J, Eden S, Stockbrügger RW. Assesment of Oro-coecal Transit Time by Means of a Hydrogen $\left(\mathrm{H}_{2}\right)$ Breath Test As Compared with a Radiologic Control Method. Scand J Gastroenterol 1986;21:669-677

43. Bradley EL, Isaacs J, Hersch T, Davidson ED, Milikan W. Nutritional consequences of total gastrectomy. Ann Surg 1975;182:415-429

44. Bjørneklett A, Fausa O, Midtvedt T. Small-Bowel Bacterial Overgrowth in the Postgastrectomy Syndrome. Scand J Gastroenterol 1983;18:277-287

45. Drasar BS, Shiner M. Studies on the intestinal flora. Part II Bacterial flora of the small intestine in patients with gastrointestinal disorders. Gut $1969 ; 10: 812-819$

46. Tovey FI, Godfrey JE, Lewin MR. A gastrectomy population: 25-30 years on. Postgrad Med 』1990;66:450-456 
47. Magnusson B, Faxen A, Cederblad A, Rosander L, Kewenter J, Hallber L. The effect of parietal cell vagotomy and selective vagotomy with pyloroplasty on iron absorption. A prospective randomized study. Scand J Gastroenterol 1979:14:177182

48. Amaral JF, Thompson WR, Caldwell MD, Martin HF, Randall HT. Prospective hematologic evaluation of gastric exchusion surgery for morbid obesity. Ann Surg $1985 ; 201: 186-193$

49. Harju E. Metabolic problems after gastric surgery. Int Surg 1990; 75:27-35

50. Giannella RA. Toskes PP. Gastrointestinal bleeding and iron absorption in the experimental blind loop sydrome. Am J Clin Nutr 1976;29:754-757

51. Kumar A, Forsmark CE, Toskes PP. The response of small bowel bacterial overgrowth to treatment: Effects of coexisting conditions. Gastroenterology $1995 ; 110: A 340$

52. Venturi M, Zuccato E, Restelli A, Mazzoleni L, Mussini E, Doldi SB. Utility of hydrogen and methane breath tests in combination with $\mathrm{X}$-ray after a barium meal in the diagnosis of small bowel bacterial avergrowth after jejuno-ileal bypass for morbid obesisty. Obes Surg 1994;4:144-148

53. Willard MD, Simpson RB, Delles EK, Coben ND, Fossum TW, Kolp D, Reinhart G. Effects of dietary supplementation of fructo-oligosaccharides on small intestinal bacterial overgrowth in dogs. Am I Vet Res 1994;55:654-659

54. Attar A, Bouhnik Y, Flourié B, Franchisseur C, Crenn P, Briet F, Ruszniewski P, Rambaud JC. Efficacy of two antibiotics and a probiotic in the treatment of small intestinal bacterial overgrowth. Gastroenterology 1995; 1. 10:A310

55. Kumar A, Forsmark CE, Toskes PP. Small bowell bacterial overgrowth: The changing face of an old disease. Gastroenterology 1995;110:A340 


\section{Chapter VIII}

\section{Determinants of Medico-Social Functioning after Total Gastrectomy}

R Brägelmann, U Armbrecht, D Rosemeyer, A Volovics, W Zilly, RW Stockbrügger

(Accepted for publication in Disability and Rehabilitation) 


\section{Abstract}

\section{Aim}

To describe medico-social functioning after total gastrectomy and the factors determining it.

\section{Patients and methods}

In three medical rehabilitation centres, 173 consecutive patients after potentially curative total gastrectomy for gastric malignancy were evaluated for pre- and post-operative parameters with potential influence on post-operative medico-social functioning as measured with the Edinburgh Rehabilitation Status Scale (ERSS). Independent influential factors for the ERSS were identified in a linear regression analysis.

\section{Results}

The median ERSS-score was 4 (IQR 2 to 6) on a scale from 0 (best) to 28 (worst). Independent factors influencing medico-social performance after total gastrectomy were blue collar work (vs. white collar work), time after operation, dyspepsia, dysphagia and intestino-oesophageal reflux.

\section{Conclusion}

Medico-social functioning was acceptable in this patient population. After total gastrectomy, dyspepsia, dysphagia, and intestinal reflux into the oesophagus need speciall attention. 


\section{Introduction}

The annual incidence and mortality rates of gastric cancer are declining in most countries ${ }^{1}$, but stomach cancer is still a major cause of morbidity and mortality world-wide ${ }^{2-4}$. Survival rates have been low ${ }^{5.7}$, but in patients operated on, they are improving ${ }^{8-10}$, possibly due to improved surgical technique ${ }^{11.26}$ and earlier diagnosis $^{9.21 \cdot 29}$.

Optimising quality of life in the gastrectomised patient has been recognised as a point of concern ${ }^{30,31}$. Most studies regarding quality of life after total gastrectomy compare the influence of different types of gastric reconstruction. The results of these studies are diverging ${ }^{32-48}$.

No single factor is known determining medico-social functioning after gastrectomy. Pre-operative patient and tumour characteristics, intestino-oesophageal reflux ${ }^{49}$, small bowel bacterial overgrowth ${ }^{50-53}$, shortened oro-coecal transit time ${ }^{52}$, abdominal symptoms $s^{32,40,43,45}$, nutrient malassimilation and diarrhoea ${ }^{39,45}$, and psychological factors ${ }^{54}$ are discussed as possible influential factors.

The aim of this study was to describe medico-social functioning after total gastrectomy and to elucidate which factors are determining it.

\section{Patients and methods}

During the period from May 1990 to January 1993, 196 consecutively admitted patients following a potentially curative total gastrectomy for gastric malignancy were seen at three German gastroenterological rehabilitation hospitals in Bad Kissingen, Bad Driburg, and Bad Brückenau. The first clinic mainly serves bluecollar workers, whilst the latter two preferably deal with patients employed in the public sector as administrators. In Germany patients after major surgery have the opportunity of admission to a rehabilitative centre. The study patients, thus, were electively referred for rehabilitative purposes without known acute or serious disease at that moment. Of the 196 patients, 14 had been admitted for the second time, and in eight patients a cancer recurrence and/or metastasis was diagnosed shortly after admission. In one of the remaining 174 patients, medico-social functioning was accidentally not assessed on admission. These 23 patients were not included in the study. The remaining 173 patients $(f=62, m=111$; median age 58 (IQR 50 to 66) years) were evaluated on the average 206 days (median; IQR 56 to 644) after the potentially curative total gastrectomy. 


\section{Basic evaluation}

After clinical and biochemical investigation on admission, all patients were asked regarding the presence of the following abdominal symptoms: dyspepsia, bloating, early satiety, reflux, dysphagia, dumping, vomiting; also overall well-being was evaluated. Body mass was measured applying the Quetelet index (weight/height; normal range 20.0 to $25.0 \mathrm{Kg} / \mathrm{m}^{2}$ ), using anamnestic data for weight in health and reported data at the time of operation and admission.

\section{Controlled diet period}

Patients who were on pancreatic enzyme supplementation at the time of hospital admission were asked to discontinue this. All patients were then put on a standardised diet for five days. During the diet period, meals were composed of $48 \%$ fat, $17 \%$ protein, and $35 \%$ carbohydrates respectively. The individual nutritional intake was quantified at every meal by an attending dietician and summarised each day. During the period of controlled diet abdominal complaints, faecal frequency, and faecal consistency were scored daily according to a questionnaire-interview and a five-day-score of each parameter was reported. The scale of the symptom score ranged from 0.000 (no complaints) to 3.000 (worst possible complaints).

\section{Fat malassimilation}

During the last three days of the controlled diet period faecal mass and faecal fat output were assessed, the latter according to the method of van de $\mathrm{Kamer}^{\mathrm{s}}$. Fat assimilation was calculated as the proportion of fat output compared to the intake.

\section{Endoscopy}

An upper endoscopy was performed on each patient, unlless it had been performed during the previous two months. In these cases the endoscopic diagnosis from the last examination was recorded. Endoscopic diagnosis was coded: $0=$ normal, 1 =oesophagitis I, 2 =oesophagitis II, $3=$ oesophagitis III, $4=$ food retention without evident stenosis, $5=$ fibrotic stenosis.

\section{Oro-coecal transit time and small bowel bacterial overgrowth}

The frequency of rapid upper intestinal transit and small bowel bacterial overgrowth were evaluated simultaneously using a modification of the $\mathrm{H}_{2}$-breath test described by Ambrecht et al. with a standard test meal and radiopaque markers ${ }^{56}$. This modification has been described in detail before ${ }^{51}$. 


\section{Medico-social functioning}

In order to assess medico-social dysfunction the Edinburgh Rehabilitation Status Scale (ERSS) was recorded by one of the authors on the day of admission ${ }^{57}$. The ERSS ranges from 0 to 28 points, with higher figures indicating a poorer medicosocial functioning. The ERSS measures dimensions of medico-social performance in four different subscales: Independence/dependence, activity/inactivity, social integration/social isolation, and effects of symptoms on lifestyle. These subscale points are summed up to the final score which is reported here. In one centre, however, the specific subscales were recorded as well. The Edinburgh Rehabilitation Status Scale has been tested in several somatic patient groups in rehabilitative medicine $e^{57-62}$. The inter-rater reliability is good ${ }^{57}$ and there is good correlation to the Barthel Index and the Pulses profile ${ }^{61}$. Table VIII.1 gives the final scores for different patient groups as reported by Affleck et al. ${ }^{s}$.

Table VIII.1 Mean Edinburgh Rehabilitation Status Scale (ERSS) scores in different patient groups according to Affleck et al. ${ }^{\text {s7 }}$

\begin{tabular}{lc}
\hline Patient groups & ERSS \\
\hline Upper limb \& neck lesions & 7.7 \\
Back-pain syndrome & 9.8 \\
Arthritis & 10.0 \\
Cardiac & 14.9 \\
Amputation & 15.4 \\
CNS excluding CVA & 16.7 \\
CVA & 18.0 \\
Multiple impairment & 18.3 \\
\hline
\end{tabular}

Adapted from Affeck th al. ${ }^{57}$ : scale $0-28$ (best to worst)

\section{Statistics}

First, a description of the whole group using medians and interquartile ranges (IQR) for continuous parameters is given. To elucidate the factors influencing medico-social functioning, a linear regression analysis was performed with all the available variables. The diagnosis of the endoscopic examination was not included in the analysis, because only $48 \%$ of our patients had an endoscopic examination. To account for missing values in other variables we substitued the mean value (continuous values) or zero (categorical variables) for the missing value and included a missing indicator variable in the analysis ${ }^{63}$. 


\section{Ethics}

The protocol was approved by the ethical committee of the Bayerische Landesärztekammer, Germany.

\section{Results}

\section{Patient characteristics}

Gender, age, time since operation, tumour stage, type of operation, and the distribution according to clinical centre are given in Table VIII.2.

Table VIII.2 Demographical parameters, tumour, and surgical data in 173 patients after total gastrectomy

\begin{tabular}{|c|c|c|c|c|c|}
\hline \multirow{2}{*}{ Female/male } & & number of patients & \multirow[t]{2}{*}{ median } & \multirow[t]{2}{*}{ IQR } & \multirow[b]{3}{*}{66} \\
\hline & & $62 / 111$ & & & \\
\hline Age (years) & & 173 & 58 & 50 & \\
\hline Time since op & ation (days) & 167 & 206 & 56 & 644 \\
\hline \multirow[t]{3}{*}{ Tumour stage } & 0 & 4 & & & \\
\hline & IA & 48 & & & \\
\hline & $\mathbb{B}$ & 37 & & & \\
\hline \multirow[t]{3}{*}{ According to } & II & 23 & & & \\
\hline & IIIA & 22 & & & \\
\hline & IIIB & 8 & & & \\
\hline \multirow[t]{2}{*}{ UTCC } & IV & 7 & & & \\
\hline & Lymphomas & 24 & & & \\
\hline \multicolumn{2}{|c|}{ Duodenal bypass without pouch } & 87 & & & \\
\hline \multicolumn{2}{|c|}{ Duodenal bypass with pouch } & 27 & & & \\
\hline \multicolumn{2}{|c|}{ Continuous duodenal transit } & 27 & & & \\
\hline \multicolumn{2}{|c|}{ Other type of reconstruction } & 32 & & & \\
\hline \multirow[t]{3}{*}{ Clinic } & Bad Kissingen & 78 & & & \\
\hline & Bad Driburg & 73 & & & \\
\hline & Bad Brückenau & 22 & & & \\
\hline
\end{tabular}

\section{Biochemistry}

Haematological and biochemical data is shown in Table VIII.3. Anaemia (haemoglobin $<133 \mathrm{~g} / \mathrm{L}$ ) and sideropenia (ferritin $<20 \mu \mathrm{g} / \mathrm{L}$ ) were present in $46 \%$ and $31 \%$, respectively. 
Table VIII.3 Haematological and biochemical data in patients after tota gastrectony

\begin{tabular}{|c|c|c|c|c|c|}
\hline \multirow[b]{2}{*}{ Haemoglobin (g/L) } & \multicolumn{2}{|c|}{ number of patients } & \multirow{2}{*}{$\frac{\text { medlan }}{134}$} & \multicolumn{2}{|c|}{$\mathbb{M Q R}$} \\
\hline & 169 & & & 125 & 144 \\
\hline Patients with $<133 \mathrm{~g} / \mathrm{L}$ & 78 & $46 \%$ & & & \\
\hline Ferritin $(\mu \mathrm{g} / \mathrm{L})$ & 164 & & 45 & 17 & 114 \\
\hline Patients with $<20$ & 51 & $31 \%$ & & & \\
\hline Albumin (g/l) & 163 & & 43.5 & 39.9 & 47.6 \\
\hline Patients with $<35 \mathrm{~g} / \mathrm{L}$ & 10 & $6.1 \%$ & & & \\
\hline
\end{tabular}

\section{Endoscopy}

In 83 of the 173 patients (48\%) an upper intestinal endoscopy was performed. Pathological findings were present in $34 \%$ of the patients. Of these patients, most had mild to moderate oesophagitis (Table VIII.4).

Table VIII.4 Frequency of findings at upper intestinal endoscopy, of small bowel bacteriall overgrowth, and of shortened oro-coecal transit in patients after total gastrectomy

\begin{tabular}{|c|c|c|c|}
\hline & number of patients evaluable & yes & $\%$ \\
\hline Upper intestinal endoscopy & 83 & & \\
\hline Normal & & 55 & 66 \\
\hline oesophagitis I & & 11 & 13 \\
\hline oesophagitis II & & 7 & 8 \\
\hline oesophagitis III & & A & 5 \\
\hline food retention without evident stenosis & & 3 & 4 \\
\hline fibrotic stenosis & & 3 & 4 \\
\hline Pathological findings & & 28 & 34 \\
\hline Small bowel bacterial overgrowth ${ }^{*}$ & & 47 & 37 \\
\hline Oro-coecal transit time $<75$ minutes & & 34 & 21 \\
\hline
\end{tabular}

- 34 patients with fast transit, $3 \mathrm{H}_{2}$-non-producers; 9 patients with technical problems

\section{Small bowel bacteriall overgrowth and oro-coecal transit time}

The test was not evaluable for bacterial overgrowth in 34 patients because of fast transit, in three patients because they were $\mathrm{H}_{2}$-non-producers, and in nine patients because of technical problems. Small bowel bacterial overgrowth was diagnosed in 
$37 \%$ of the remaining 127 patients (Table VIII.4).

In nine patients the test was unreliable for the evaluation of fast transit because of technical problems. An oro-coecal transit time below 75 minutes was seen in $21 \%$ of the patients (Table VIII.4).

\section{Symptoms}

Symptoms were reported by $86 \%$ of the patients. Meteorism, dyspepsia, and early satiety were the complaints most commonly described by $68 \%, 65 \%$ and $55 \%$ of the patients, respectively. Reflux and dysphagia were present in 27 and $21 \%$ respectively. The median total symptom score was 0.365 on a scale from 0.000 to 3.000 (Table VIII.5).

Table VIII.5 Frequency and severity of symptoms in 173 patients after total gastrectomy

\begin{tabular}{|c|c|c|c|c|}
\hline & number of patients & yes & $\%$ & \\
\hline Any symptom & 173 & 149 & 86 & \\
\hline Meteorism ${ }^{*}$ & 71 & 48 & 68 & \\
\hline Dyspepsia & 173 & 113 & 65 & \\
\hline Early satiety & 173 & 95 & 55 & \\
\hline Retlux & 173 & 46 & 27 & \\
\hline Dysphagia & 173 & 36 & 21 & \\
\hline \multirow[t]{2}{*}{ Vomiting } & 173 & 21 & 12 & \\
\hline & & median & \multicolumn{2}{|c|}{ IQR } \\
\hline \multicolumn{5}{|l|}{ Symptom score } \\
\hline scale from $0.000-3.000$ & 163 & 0.365 & 0.163 & 0.692 \\
\hline
\end{tabular}

* meterrism was asked in 71 pattients only"

\section{Body mass, calorie intake, bowel habits, and fat malassimilation}

Median body mass in health, at operation, and on admission were $26.2,23.8$, and $22.0 \mathrm{~kg} / \mathrm{m}^{2}$, respectively. Twenty-five $\%$ of the patients were underweight.

Median weight loss since operation was $9.5 \%$. The median calorie intake per kilogram body weight and day was 37.7 . Only $25 \%$ of the patients consumed less than 30.3 calories per $\mathrm{Kg}$ body weight and day (Table VIII.6).

In general, the patients had a normal faecal frequency and faecal consistency. The faecal mass was slightly elevated. Median faecal fat excretion was $13.0 \mathrm{~g} /$ day, with steatorrhoea (defined as $>7$ gram per day) present in $73 \%$ of the patients (Table VIII.6). 
Table VII.6 Weight development, calorie intake, and bowel habits in 173 patients after total gastrectomy

\begin{tabular}{|c|c|c|c|c|}
\hline & number of patients & median & \multicolumn{2}{|c|}{ IQR } \\
\hline \multicolumn{5}{|l|}{ Weight development } \\
\hline Body mass index in health & 170 & 26.2 & 24.1 & 29.0 \\
\hline Body mass index at operation. & 170 & 23.8 & 21.3 & 26.9 \\
\hline Body mass index on admission & 170 & 22.0 & 20.0 & 24.0 \\
\hline Loss of body mass since operation in $\%$ & 170 & 9.5 & -20 & 16.4 \\
\hline Calorie intake per kg body weight and day" & 154 & 37.7 & 30.3 & 43.1 \\
\hline \multicolumn{5}{|l|}{ Bowel habits during the controlled diet period } \\
\hline Faecal frequency $\quad$ per day & 162 & 1.2 & 1.0 & 2.0 \\
\hline Faecal consistency" scale $0.0-3.0$ & 173 & 1.0 & 1.0 & 2.0 \\
\hline grams per day & 152 & 219 & 138 & 324 \\
\hline grams per day & 165 & 13.0 & 6.2 & 21.9 \\
\hline Fat malassimilation $\%$ of intake & 158 & 11.6 & 5.1 & 19.6 \\
\hline
\end{tabular}

"denotes calorie intake per $\mathrm{Kg}$ body weight per day: " faecal consistency is ranked: $0=$ no stool, $1=$ normally formed, 2 =soft, $3=$ watery diarthoea

\section{Medico-social performance}

On admission the whole group of patients had a median ERSS-score of four (IQR 2 to 6) with a range from zero to 17 points (Figure VIII.1). Affleck ${ }^{57}$ described a score $\leq 8$ as a high level of medico-social functioning; only 10.4 percent of the patients had a higher score than eight. Looking at the subscales, the fields inactivity and effects of symptoms on lifestyle indicated most severe dysfunction (Figure VIII.2).

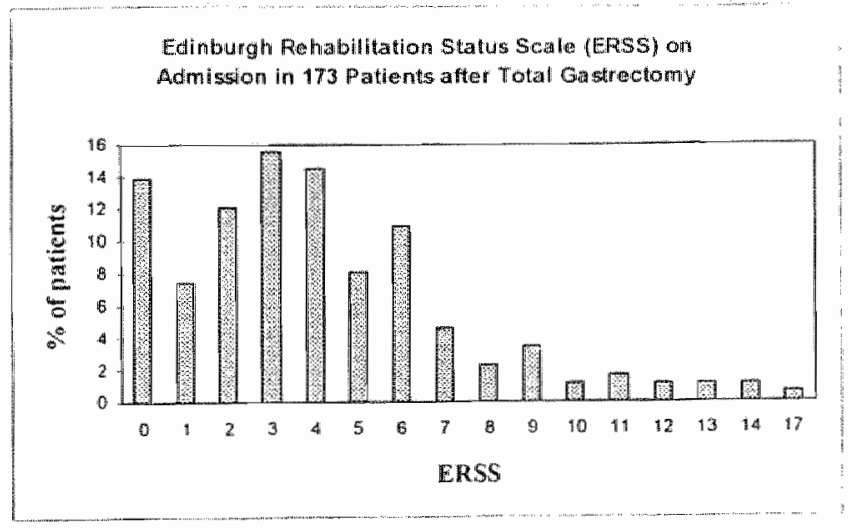

Figure VIII.I

Edinburgh Rehabilitation Status Scale (ERSS) on admission in 173 patients after total gastrectomy. Given are the percentages of patients (vertical axis) with al distinct total ERSS-score (horizontal axis, scale 0 (best) to 28 (worst) 


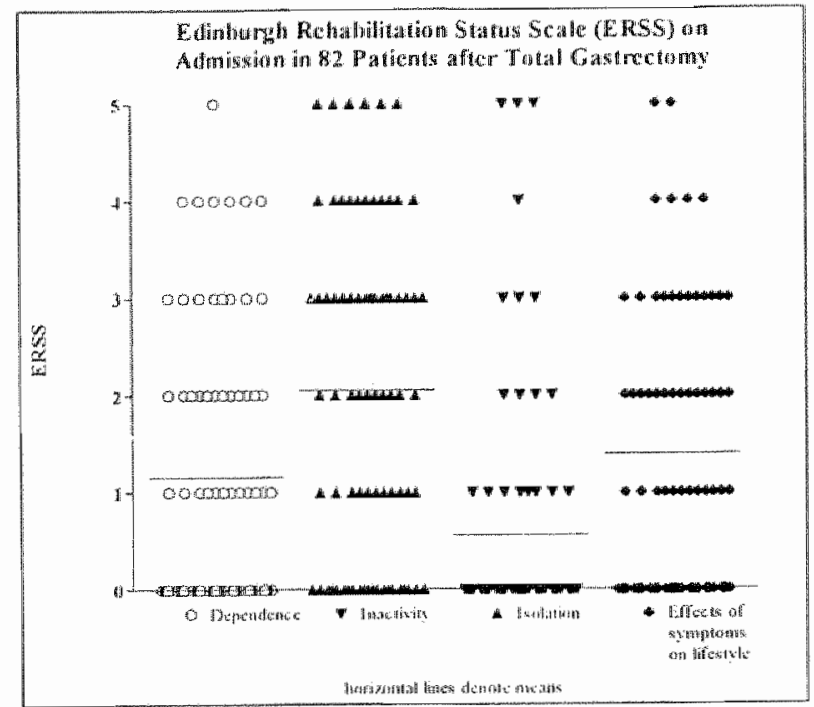

Figure VIII.2 Edinburgh Rehabilitation Status Scalle (ERSS) subscores on admission measured in a subset of 82 patients after total gastrectomy. Scale 0 (best) to 7 (worst). The horixontal lines denote the means.

\section{Linear regression analysis of factors influencing medico-social functioning}

The results of the linear regression analysis are given in Table VIII.7.

There was a remarkable difference in the ERSS-scores between the three different clinics. Patients in Bad Kissingen had significantly higher scores than patients from Bad Driburg and almost significantly higher scores than patients from Bad Brückenau. Assuming all other variables to be stable, the average ERSS-score would be 2.13 points higher for patients in Bad Kissingen and 0.87 points higher for patients in Bad Brückenau compared to patients in Bad Driburg.

Female patients had higher scores than male patients and older patients had higher scores than younger patients, but these differences were not statistically significant. The ERSS-scores improved significantly with time since operation. Assuming all other variables to be stable, the average ERSS-score would be $22 \%$ lower after one year compared to the situation directly after operation.

Higher albumin values were significantly correlated with lower ERSS-scores and higher haemoglobin levels were significantly associated with higher ERSS-scores.

Some symptoms had a significant relationship with higher ERSS-scores, i.e. impaired medico-social functioning. Dyspepsia was related to $65 \%$ and dysphagia to $62 \%$ higher average ERSS-scores, respectively. Intestino-oesophageal reflux was associated with $71 \%$ higher ERSS-scores. Increasing degrees of pathollogical findings at upper intestinal endoscopy were positively correlated with the ERSSscores in a univariate analysis ( $p<0.0001$, Figure VIII.3). 
Table VIII.7

Independent factors influencing medico-social functioning in 173 patients after total gastrectomy as identified in a linear regression analysis

\begin{tabular}{|c|c|c|c|c|c|c|}
\hline \multicolumn{2}{|l|}{ Variable } & coefficient & STDerr & $p$ & \multicolumn{2}{|c|}{$95 \%$ canf interval } \\
\hline Clinic & & & & $<0.0001$ & & \\
\hline \multicolumn{7}{|l|}{ Bad Kissingen (ref.) } \\
\hline \multicolumn{2}{|l|}{ Bad Driburg } & -2.23 & 0.48 & & -3.18 & -1.28 \\
\hline \multicolumn{2}{|l|}{ Bad Brickenau } & -11.26 & 0.66 & & -2.57 & 0.04 \\
\hline \multicolumn{2}{|l|}{ Female } & 0.83 & 0.44 & 0.0158 & -0.03 & 1.69 \\
\hline \multicolumn{7}{|l|}{ Male (ref.) } \\
\hline \multicolumn{2}{|l|}{ Age (per year) } & 0.035 & 0.02 & 0.067 & 0.00 & 0.07 \\
\hline \multicolumn{2}{|c|}{ Time since operation (years) } & -0.22 & 0.07 & 0.002 & -0.36 & -0.08 \\
\hline \multirow[t]{2}{*}{ Laboratory findings } & Haemoglobin $(g / L)$ & 0.03 & 0.10 & 0.032 & 0.00 & 0.06 \\
\hline & Albumin $(\mathrm{g} / \mathrm{L})$ & -0.10 & 0.04 & 0.0006 & -0.18 & -0.03 \\
\hline \multirow[t]{4}{*}{ Synuptoms } & no symptoms (ref.) & & & & & \\
\hline & Reflux & 1.52 & 0.46 & 0.001 & 0.60 & 2.43 \\
\hline & Dysphagia & 1.31 & 0.50 & 0.010 & 0.31 & 2.30 \\
\hline & Dyspepsia & 1.38 & 0.44 & 0.002 & 0.50 & 2.25 \\
\hline \multicolumn{2}{|l|}{ Constant } & 2. 13 & 2.41 & 0.378 & -2.63 & 6.89 \\
\hline
\end{tabular}

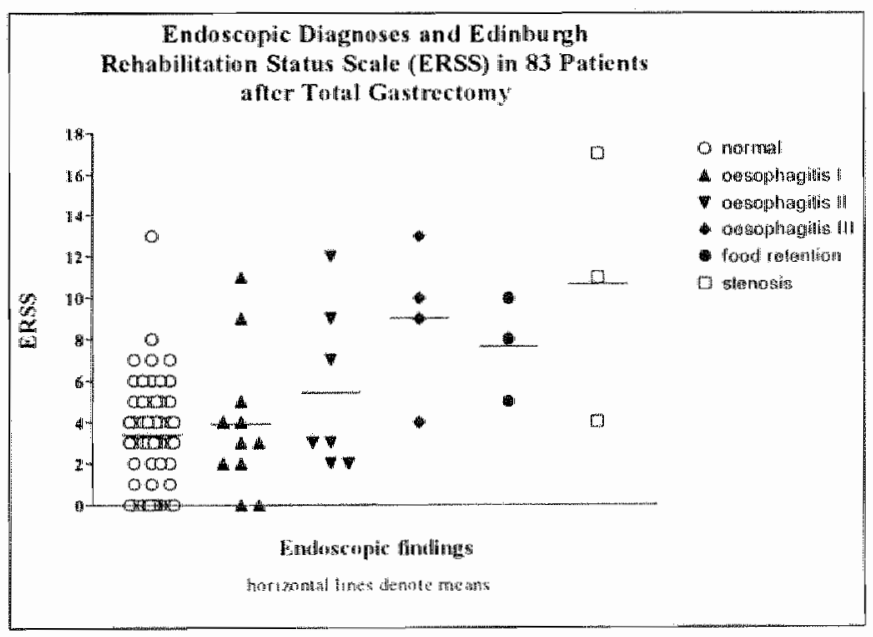

Figure VIII.3 Endoscopic diagnosis in relation to Edinburgh Rehabilitation Status Scale (ERSS) it 83 patients after total gastrectomy. Endoscopic diagnosis was coded: $0=$ mormal, $1=$ oesophagitis I, 2 =nesophagitis II, 3 =oesophagitis III, $4=$ food retention without evident stenosis, 5 =fibrotic stenosis. The ERSS-score ranges from 0 (best) to 28 (worst). The horizonal lines denotes the means. 


\section{Discussion}

Many patients and physicians consider total or subtotal gastrectomy a catastrophe. The denomination "gastric cripple" reflects the presumed quality of life in a illustrative way.

Studying specific pre- and post-operative variables with regard to their influence on medico-social functioning after total gastrectomy might elucidate areas where preventive or therapeutic action might be useful.

In this retrospective multicentre study in three gastroenterological rehabilitation centres we evaluated a large homogeneous group of patients after potentially curative total gastrectomy for gastric malignancy. The patient population had in general been operated on for early stage tumour. Patients with persisting or recurrent malignancy was excluded by thorough clinical investigation in all cases. The patient group, therefore, per definition constitutes a selected subpopulation after gastric cancer surgery which has a fairly good prognosis. To us it seemed important to assess medico-social functioning in this group which possibly will be a subject for medico-social care on longer terms.

Overall, somatic parameters in our patients were frequently impaired, but not to a severe degree. This is reflected by the generally low ERSS-score on admission and is in accordance with findings of other authors ${ }^{54,58,64}$. Looking at the subscales of the ERSS it is remarkable that inactivity and symptom induced lifestyle changes scored highest, whilst social isolation after surgery for malignancy, often considered to be of importance ${ }^{65}$, did not seem to be a major problem. This, however, might be due to the specific type of post-therapeutic handicap after treatment for other types of diseases (e.g. breast cancer).

The ERSS-scores were significantly different in the three clinics. One possible explanation is a difference due to the doctors performing the rating, but the interrater reliability of the ERSS is reported to be very good ${ }^{57}$. Another possible explanation is a difference in social background of the patients of the three clinics. The first centre (Bad Kissingen) serves mostly blue-collar workers who might define their conception of well-being more on physical ability, whereas the latter two centres preferably deal with administrative employees. Body self-esteem has been reported to be important in cancer patients ${ }^{66}$. Psychological counselling might be of use for patients with severe disturbance of their body self-esteem. It may be that the impact of a decreased physical strength is different for the two working situations. In this case, social advice regarding re-integration into the working force and necessary and/or possible changes in working life might be useful.

The improvement of medico-social functioning with time since operation probably reflects recovery after the operation, as well as physical, psychological and social adaptation to the post-operative situation. This is consistent with the literature ${ }^{67}$. However, also the positive selection of tumour-free survivors may play a role. 
As is to be expected, higher albumin values, indicative of a better healh, correlated with better medico-social performance. On the other hand, it is not really clear, why higher haemoglobin values were associated with a higher ERSSscore, i.e. impaired medico-social functioning. Smoking habits with subsequent polyglobulinaemia might interfere with this evaluation. They were, however, not recorded.

Symptoms of dyspepsia, dysphagia, and reflux into the oesophagus llad a greal impact on medico-social performance after total gastrectomy, although they were not necessarily the most frequent events. While dyspepsia is a common complaint of the patient after total gastrectomy, dysphagia and reflux were of relatively low frequency in our sudy group. Nevertheless, they interfered with post-operative performance to a substantial extent. The influence of dysphagia and reflux on the ERSS is reflected by the positive correlation of the severity of pathological findings at upper intestinal endoscopy, namely oesophagitis of different degrees and/or stenosis, and the ERSS-score. However, the small number of patients with severe endoscopic findings and the wide range of the corresponding ERSS-scores should be noted and the interpretation has to be cautious.

Treatment for dyspepsia after total gastrectomy is hampered because the pathophysiology is not clearly understood. Dyspepsia, a relatively vague denomination for upper Gl-symptoms can have a multitude of causes, either alone or in combination. Some regard dyspepsia after total gastrectomy to be due to pancreatic insufficiency. Abdominal cramps can also be due to early dumping. Van der Kleij discussed the possibility that this is caused by accelerated small intestinal transit $^{68}$. In our data, no significant correlation between medico-social functioning and oro-coecal transit times were found. Dyspepsia after total gastrectony, therefore, remains unexplained.

Dysphagia after total gastrectomy can be due to a fibrotic stenosis of the oesophago-intestinal anastonosis or an inflammatory stenosis in reflux patients. The former can be treated locally with dilatation, the latter faces the more difficult problem of reflux. Treatment for intestinal reflux into the oesophagus after total gastrectomy is difficult as the reflux is alkaline in nature. A Roux-en-Y construction with a 40 - to $50-\mathrm{cm}$ long Roux-segment is most often the only solution ${ }^{69}$.

It is not only interesting to note which factors influence post-operative performance in patients with total gastrectomy, but also those that do not. Preserved duodenal transit and/or pouch reconstruction were not of any influence ${ }^{48}$. In a previous evalluation, using a univariate approach, the presence of small bowel bacterial overgrowth in patients with tolal gastrectomy was associated with a worse medicosocial functioning" In the present study, however, this finding could no longer be demonstrated. Although early satiety is frequently experienced by the patients, it is not reported as a major complaint. This is also reflected in the high calorie intake 
and the small number of underweight patients. Bowel habits did not influence the post-operative medico-social functioning, although faecal mass was slightly and faecal fat substantially elevated in patients after total gastrectomy.

In conclusion, the study group - who constitutes a subpopulation with a potentially good prognosis - had a very good medico-social functioning after curative total gastrectomy for gastric malignancy. Medico-social functioning was influenced by a number of different factors reflecting the social situation and upper abdominal symptoms. Clinical and outpatient rehabilitative centra with special interest in chronic gastrointestinal disorders form an ideal environment to take care of these patients, as physical findings, psychological factors, and the social situations of the patient can be assessed simultaneously and can be influenced by the team approach of different health professionals. 


\section{References}

1. Parkin D, Laara E, MuirC. Estimate of the world-wide frequency of sixteen major cancers in 1980. Int J Cancer 1988:411:184-197

2. Davis DL, Hoel D. Fox J, Lopez A. Epidemiology: International trends in cancer mortality in France, West Germany, Italy, Japan, England and Wales, and the USA. Lancet 1990;336:474-481

3. Boland CR, Scheiman JM. Tumours of the Stomach. In: Yamada T, Alpers DH, Owyang C, Powell D, Silverstein F (eds). Textbook of Gastroenterology. Philadelphia: J.B. Lippincott, 1995; 1:1494-1523

4. Neugut AI, Hayek M, Howe G. Epidemiology of Gastric Cancer. Semin OncolGastric Cancer 1996;23:281-291

5. Becker HD. Radikalitätsprinzipien beim Magencarcinom-eine kritische Betrachtung. Chirurg 1991:62:878-880

6. Diehl JT, Hermann RE, Cooperman AM, Hoerr SO. Gastric Carcinoma-A TenYear Review. Ann Surg 1983;198:9-12

7. Wanebo HJ, Kennedy BJ, Chmiel J, Steele B, Winchester D, Osleen R. Cancer of the stomach. A patient care study by the American College of Surgeons. Ann Surg 1993;218:583-592

8. Gall FP, Altendorf A, Hermanek P, Gentsch HH. Chirurgische Therapie des Magenkrebses-Stagnation oder Fortschritte? Ergebnisse bei 2665 MagenkrebsPatienten. Fortschr Med 1982;100:1876-1882

9. Sue-Ling HM, Johnston D, Martin IG et al. Gastric cancer: a curable disease in Britain. BMJ 1993;307:591-595

10. Takeda J, Koufuji K, Kodama I et al. Total gastrectomy for gastric cancer: 12-year data and review of the effect of performing lymphadenectomy. Kurume Med J $1994 ; 41: 15-21$

11. Iida $F$. Koike $S$, Koide $N$. Extended total gastrectomy for carcinoma of the cardia. Hepato-gastroenterology 1993:40:103-106

12. Jatzko $G$, Lisborg Ph. Klimpfinger $M$, Denk $H$. Extended radical surgery against gastric cancer: low complication and high survival rates. Jpn I Clin Oncol $1992 ; 22: 102-106$

13. Maruyama K. Sasako M, Kinoshita T, Sano T, Katai H. Surgical treatment for gastric cancer: the Japanese approach. Semin Oncol-Gastric Cancer 1996;23:360368

14. MoNeer G, Bowden L, Booher R. McPeak C. Elective Tolal Gastrectomy for Cancer of the Stomach: End Results. Ann Surg 1974;180:252-256

15. Menke H. Morbidität und Letalität nach Operationen wegen Magenkarzinom. Ergebnisse einer prospektiven Untersuchung zur Bedeutung unterschiedlicher Risikofaktoren. Med Klin 1992;87:300-304

16. Meyer C, Perraud V, Rohr S, De-Manzini N, Thiry LC. Surgical treatment of adenocarcinoma of the stomach: 1969-1994. Apropos of 261 cases. J Chir Paris $1995 ; 132: 423-429$ 
17. Meyer HJ, Jahne J, Wilke H, Pichllmayr R. Surgical Treatment of Gastric Cancer: Retrospective Survey of 1,704 Operated Cases With Special Reference to Total Gastrectomy as the Operation of Choice. Semi Surg Oncol 1991;7:356-364

18. Meyer $\mathrm{HJ}$, Jahne $\mathbb{H}$, Wilke $\mathrm{H}$. Perspectives of surgery and multimodality treatment in gastric carcinoma. J Cancer Res Clin Oncol 1993;119:384-394

19. Pacelli F, Doglietto GB, Bellatone R, Alfieri S, Sgadari A, Cruciti F. Extensive versus limited lymph node dissection for gastric cancer: a comparative study of parients. Br J Surg 1993;80:1153-1156

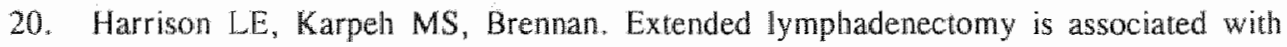
a survival benefit for node negative gastric cancer. Gastroenterology $1997 ; 122: A 1447$

21. Dietl F, Rumpf KD. Früln- und Spätergebnisse der Gastrektomie de principe. Zentrlbl Chir 1995;120:800-803

22. Guadagni $S$, Reed PI, Johnston BJ et al. Early gastric cancer: follow-up after gastrectomy in 159 patients. Br J Surg 1993;80:325-328

23. Maruyama $K$. The most important prognostic factor for the gastric cancer patient. Scand J Gastroenterol 1987;22:63-68

24. Moriguchi S, Hayashi $Y$, Nose Y Maehara Y, Korenaga D, Sugimachi K. A comparison of the logistic regression and the Cox proportional hazard models in retrospective studies on the prognosis of patients with gastric cancer. I Surg Oncol $1993 ; 52: 9-13$

25. Moureaux J, Bougaran J. Early gastric cancer. A 25-year surgical experience. Ann Surg 1993;217:347-355

26. Pinto $\mathbb{E}$, Roviello $\mathbb{F}$, de Stefano A, Vindigni $C$. Early gastric cancer: report on 142 patients observed over 13 years. Jpn J Clin Oncol 1994:24:12 19

27. Spataro V, Genoni M, Maurer C, Müller W. Stomach cancer: 10 years experiences with surgical treatment and possibilities for improving the prognosis. Helv Chir Acta 1993;59:589-595

28. Farley DR, Donohue JH, Nagorney DM, Carpenter HA, Katzmann JA, Ilstrup DM. Early gastric cancer. Br J Surg 1992;79:539-542

29. Hisamichi S. Screening for Gastric Cancer. World J Surg 1989;13:31-37

30. Troidl H. Lebensqualität: ein relevantes Zielkriterium der Chirurgie. Chirurg $1989 ; 60: 445-449$

31. Bozzeti F. Total versus subiotal gastrectomy in cancer of the distal stomach: facts and fantasy. Eur I Surg Oncol 1992;18:572-579

32. Anderson ID, Maclntyre IM. Symptomatic outcome following resection of gastric cancer. Surg Oncol 1995;4:35 40

33. Bulyl K. Schlag P, Herfarth C. Quality of life and functional results following different dypes of resection for gastric carcinoma. Eur J Surg Oncol 1990;16:404 409

34. Buhl K, Lehnert T, Schlag P, Herfarth C. Reconstruction after gastrectomy and quality of life. World J Surg 1995; 19:558-564 
35. Descottes $B$, Thognon $P$, Valleix $D$, Sodji $M$, Breville G. Antarieu $S$. Gastrectomies totales et viscerosynthese. J Chir Paris 1995:132:3336-3341

36. Jentschura D, Strohmeier N, Winkler $M$, Sturm J. Comparative study of the quality of life after stomach resection. Langenbecks Arch Chir Suppl 1996;113:247-248

37. Korenaga D, Orita H, Okuyama $T$, Moriguchi $S$, Maehara $Y$, Sugimach K. Quality of life after gastrectomy in patients with carcinoma of the stomach. Br I Surg 1992;79:248-250

38. Raab $M$, van Maercke $P$, Stützer $H$. Quality of life following gastrectomy-a comparison of Longmire and Roux stomach replacement methods. Zentralb| Chir $1987 ; 112: 1140-1145$

39. Roder JD, Herschbach P, Henrich G, Nagel M, Böttcher K, Siewert IR. Lebensqualität nach totaler Gastrektomie wegen Magenkarzinoms. Ösophagojejunoplicatio mit Pouch versus Ösophagojejunostomie ohne Pouch. Disch Med Wochenschr 1992:117:241-247

40. Roder JD, Stein HJ, Eckel $F$ et al. Vergleich der Lebensqualităt nach subtotaler und totaler Gastrektomie beim Magenkarzinom. Dtsch Med Wochenschr 1996;121:543549

41. Schmitz R, Moser KH, Treckmann I. Lebensqualieăt nach prograder Jejunuminterposition mit und ohne Pouch. Eine prospektive Studie bei Magencarcinompatienten zur Frage des Reservoirs ais Rekonstruktionsprinzip nach totaler Gastrektomie. Chirurg 1994;65:326-332

42. Schwarz $\mathrm{A}$, Büchler $\mathrm{M}$, Usinger $\mathrm{K}$ et al. Importance of the duodenal passage and pouch volume after total gastrectomy and reconstruction with the U/m pouch: prospective randomized clinical study. World I Surg 1996;20:60-67

43. Stier A, Hölscher A.H, Schwaiger M, Siewert JR. Jejunumpouch nach totaler Gastrektomie-Klinische und szintigraphische Untersuchungen zu Funktion und Befindlichkeit. Zentralbl Chir 1994;119:838-844

44. Svedlund J, Sullivan M, Liedman B, Lundell L, Sjodin I. Quality of Life after Gastrectomy for Gastric Carcinoma: Controlled Study of Reconstructive Procedures. World J Surg 1997:21:422-433

45. Troidl $H$, Kusche J, Vestweber JH, Eypasch E, Maul U. Pouch versus oesophagojejunuostomy after total gastrectomy: A randomized clinical trial. World J Surg 1987;11:699-712

46. Junginger TH, Walgenbach S. Postgastrectomy Reconstruction By Esophagojejunostomy Roux-en-Y. Nutrition 1988;4:239-242

47. Fuchs KH, Thiede A, Engemamn R, Deltz E, Stremme O, Hamelmann $H$. Reconstruction of the food passage after total gastrectomy: randomized trial. World J Surg 1995; 19:698-705

48. Brägelmann R, Armbrecht U, Rosemeyer D, Schneider B, Zilly W, Stockbrügger RW. Total Gastrectomy: The Influence of Preserved Duodenal Transit and of Pouch Reconstruction on Abdominal Sympioms, Nutrient Assimilation, and Medico-Social Functioning. German J Gastroenterol 1996;9:555

49. Herfarth C, Schlag P, Buhl K. Surgical Procedures for Gastric Substitution. World J Surg 1987;11:689-698 
50. Cristallo M, Braga M. Agape D, Primignani M, Zulani W, Vechi M, Murone M, sironi M, Di Carlo $W$, De Franchis R. Nutritional status, function of the small intestine and jejunal morphology after total gastrectomy for carcinoma of the stomach. Surg Gyn Obst 1986;163:225-230

51. Brägelmann R, Armbrecht U, Rosemeyer D, Schneider B, Zlly W, Stockbrügger RW. Small bowel bacteriall overgrowth in patients after total gastrectomy. Eur J Clin Invest 1997;27:409 416

52. Armbrectit $U$, Lundell $L$, Lindstedt $G$, Stockbrügger RW. Causes of malabsorption after total gastrectomy with Roux-en-Y reconstruction. Acta Chir Scand $1988 ; 154: 37-41$

53. Tabaqchali S. The Pathophysiological Role of Small Intestinal Bacterial Flora. Scand I Gastroenterol 1970;6:139-163

54. Siegrist K, Siegrist J. Psychosocial Factors in the Course of Gastric Cancer. Scand J Gastroenterol $1987 ; 22: 90-92$

55. van de Kamer JH, ten Bokkel Huinink $H$, Weyers HA. Rapid method for the determination of fat in faeces. J Biol Chem 1949;177:347-355

56. Armbrecht U, Jensen $J$, Eden $S$, Stockbrügger RW. Assessment of Oro-coecal Transit Time by Means of a Hydrogen $\left(\mathrm{H}_{2}\right)$ Breath Test As Compared with a Radiologic Control Method. Scand J Gastroenterol 1986;21:669-677

57. Affleck JW, Aitken RCB, Hunter JAA, McGuire RJ, Roy CW. Rehabilitation Status: A Measure of Medicosocial Dysfunction. Lancet 1988;1:230-233

58. Gutschmidt $S$, Hänisch $S$, Wurthner $K$. Verlaufsbeschreibung stationärer Rehabilitation bei Verdaungs-und Stoffwechselkrankheiten unter zunehmender Integration von Verhalten und Erleben. Rehabilitation 1993;32:185-196

59. Gutschmidt $S$, Hänisch $S$. Integrativer Therapieansatz in der stationären Rehabilitation von Frauen und Männern mit totaler Gastrektomie wegen Magenkarzinom. Rehabilitation 1994;33:228-236

60. Disler PB, Christopher WR, Smith BP. Predicting Hours of Care Needed. Arch Phys Med Rehabil 1993;74:139-143

61. Mattison PG, Aitken CB. Prescott RJ. Rehabilitation status-the relationship between the Edimburgh Rehabilitation Status Scale (ERSS), Barthel Index, and PULSES profile. Int Disabill Studies 1991;13:9-11

62. Mattison PG, Aitken CB. Prescott RJ. Rehabilitation status in multiple handicap. Arch Phys Med Rehabil 1992;73:926-929

63. Dawson-Saunders B, Trapp RG. Basic and Clinical Biostatistics. East Norwalk: Appleton \& Lange, 1990

64. Egli H. What constitutes Quality of Life? Methodological Considerations and Suggestions for Clinical Practice. Scand J Gastroenterol 1987;22:87-89

65. Bloom $\mathbb{J R}$, Spiegel D. The relationship of two dimensions of social support to the psychological well-being and social functioning of wonen with advanced breast cancer. Soc Sci Med 1984;19:831-837

66. Katz MR, Rodin G, Devins GM. Self-esteem and cancer: theory and research. Can J Psychiatry 1995;40:608-615 
67. Zieren HU, Zippel K. Zieren J, Muller JM. Quality of Life after Surgical Treatment of Gastric Carcinoma. Eur J Surg 1998;164:119-125

68. van der Kleij FGH, Vecht J, Lamers CBHW, Masclee AAM. Diagnostic value of dumping provocation in patients after gastric surgery. Scand J Gastroenterol $1996 ; 31: 1162-1166$

69. Debas HT, Orloff SL. Surgery for Peptic Uicer Disease and Postgastrectomy Syndromes. In: Yamada T, Alpers DH, Owyang C, Powell D, Silverstein F (eds). Textbook of Gastroenterology. Philadelphia: I.B. Lippincott 1995;1:1523-1543 


\section{Chapter IX}

\section{Coping Behaviour in Patients}

after Curative Total Gastrectomy

R Brägelmann, HH Theissen, U Armbrecht, RW Stockbrügger

(Submitted for publication) 


\section{Abstract}

\section{Background}

The aim of this study was to describe and examine coping patterns applied by the patients after a potentially curative total gastrectomy for gastric malignancy.

\section{Patients and Methods}

78 consecutive parients ( $f=25, m=53$, median age 57 years, (interquartile range $=I Q R$ 50-65)) were seen 144 days (IQR 41-546) after a curative total gastrectomy for gastric malignancy. Patients were invited to be interviewed by a psychologist, who assessed coping strategies using a validated questionnaire. The predilection for certain strategies was compared within the group and with a disease-control group from the literature. The possible relationship of tumour stage, time past operation, gender, weight loss since operation, and energy intake per kilogram body weight and day with the coping strategies was examined.

\section{Results}

Fifty of the 78 patients $(64 \%)$ agreed to be assessed by the clinical psychologist. These patients $(f=19, m=31 ; f / m=0.62)$ with a median age of 53 years (IQR 49-63) were investigated 187 days (IQR 41-573) after the total gastrectomy. The pattern compliance strategy and trust in doctors scored significantly higher than all the other fields $(p<0.0001)$. The patterns self-support and relativation by comparison had significantly higher ratings than all the other fields $(p=0.0001)$ with the exception of the field compliance strategy and trust in doctors. Problem analysis and problem solving and hedonism scored significantly higher $(\mathrm{p}=0.0003)$ than cognitive devial and dissimulation or the remaining seven fields not mentioned. The fields compliance strategy and trust in doctors, hedonism, regressive tendency, relativation by comparison and self-support had at least ten patients (20\%) above the mean score plus the standard deviation of the disease-control group, whereas only the field emotional control and social isolation had ten patients below the mean minus the standard deviation of the disease-control group. There was a positive correlation of the field hedonism with time past operation $\left(r^{2}=0.5\right.$, $\mathrm{p}<0.0001)$.

\section{Conclusion}

Active and problem-oriented coping patterns were predominant in a group of supposedly cancer-free patients after total gastrectomy for gastric malignancy. If these coping patterns are recognised by the managing physician(s), posi-operative rehabilitation can probably be further improwed. 


\section{Introduction}

Survival rates for patients with gastric cancer are improving ${ }^{1}$, due to improved surgical technique $\mathrm{e}^{2}$ and earlier diagnosis ${ }^{1,3}$. Optimising quality of life in the gastrectomised patient has been recognised as a point of concern ${ }^{4.5}$. Studies regarding quality of life after total gastrectomy mainly compare the influence of different types of gastric reconstruction ${ }^{6-12}$. Apart from this somatic approach, psychological factors influencing quality of live after the diagnosis and/or treatment of severe disease have been of growing interest. Coping strategies are one facet of these factors.

Coping studies developed from the studies of stress reactions. Coping categories are not precisely defined, but coping styles have mainly been described as "confrontative", "avoiding", "resigned", or a "non-dominant style"13. Coping behaviour has by some authors been described to be influenced by gender $\mathrm{r}^{14.15}$ and age ${ }^{16.17}$. The outcome of an operation or other therapy ${ }^{16.18}$, related to the subjective expectancies of the patient ${ }^{19}$, have been found to be of importance for coping behaviour especially. Supposedly, the ascribed meaning of symptoms ${ }^{20}$ and causal psychosocial attributions ${ }^{21}$ will effect it. Coping strategies are not exclusively a consequence of personal style ${ }^{22}$ but can also be learnt ${ }^{23-27}$. There seems to be a certain disease specificity of coping behaviour ${ }^{22,2 * 29}$. Disease-specific coping patterns might result from objective disease parameters, symptoms, physical stigmata, therapeutical requirements, or peer-group reactions ${ }^{29}$. Reports, however, are not consistent $t^{27,30,31,32}$, and hitherto no correlations have been made between disease-related parameters and coping strategies. Some coping strategies are reported to correlate with better adjustment and less emotional distress than others ${ }^{19,21.27,31,33}$. Svedlund et al. ${ }^{34}$ discuss the need for linking somatic factors to psychological performance after gastrectomy for gastric cancer.

The aim of this study was to describe the coping patterns applied by the patients after a potentially curative total gastrectomy for gastric malignancy, to examine disease-specificity, and to identify parameters of possible influence on the predilection of the patients for certain coping patterns.

\section{Patients and methods}

During the period from May 1990 to January 1993, 95 consecutively admitted patients following a potentially curative total gastrectomy for gastric malignancy were seen at a gastroenterological rehabilitation hospital in Bad Kissingen, Germany. Of the 95 patients, 13 had been admitted for the second time, and in four patients a cancer recurrence and/or metastasis was diagnosed shortly after admission. These patients were not included in the evaluation, because the intention 
of the study was to examine tumour-free patients and repeated evaluation of the same patient might falsify the results. 78 patients ( $\mathrm{f}=25, \mathrm{~m}=53 ; \mathrm{f} / \mathrm{m}=0.47$ ) with a median age of 57 years (IQR 50-65) were investigated I44 days (IQR 41-546) after the total gastrectomy.

\section{Basic evaluation}

Surgical records were scrutinised for data regarding tumour stage and outcome of the operation. On admission cancer recurrence had been excluded by thorough physical, biochemical, and when necessary by endoscopic investigation. Body mass was measured applying the Quetelet index (weight/height ${ }^{2}$; normal range 20.0 to $\left.25.0 \mathrm{Kg} / \mathrm{m}^{2}\right)$.

\section{Controlled diet period}

All patients were put on a standardised diet for five days. During the diet period, meals were composed of $48 \%$ fat, $17 \%$ protein, and $35 \%$ carbohydrates, respectively. The individual nutritional intake was quantified at every meal by an attending dietician and summarised each day.

\section{Coping behaviour}

All patients included in the study were invited to see the clinical psychologist for a personal or, if preferred, written interview to evaluate coping behaviour. The patients were totally free in their decision to accept this unvitation or to decline the offer. No reasons were inquired if patients choose not to participate.

In order to assess coping behaviour the "Freiburger Fragebogen zur Krankheitsverarbeitung - FKV $102^{\text {" }}$ of Muthny et a1..$^{35}$ was used. This questionnaire has been developed to assess coping and social support. It can either focus retrospectively on the moment when the patient was told the diagnosis, or on the week before the interview. The latter procedure was followed in this study. The questionnaire consists of 102 items which have to be rated by the patient in a range from one to five reflecting "not fitting at all" to "fits perfectly". The items are related to twelve scales which are given in the following table (Table IX.1). Higher numbers indicate that a pattern is more important for the patient.

Primarily, the predilection of the patients for the specific patterns is described with an intra-scale comparison. Thereafter, the degree to which the individual scales are applied by our patients is compared with a disease-control group from the literature consisting of patients with chronic renal insufficiency $(n=212)$ and patients with breast cancer $(n=107)^{35}$. Finally, the following variables were analysed with regard to the possible influence on coping strategies: tumour stage, time past operation, gender, weight loss since operation, and energy intake per kilogram body weight and day. For this evaluation the patients were re-grouped into three tumour groups, 
as prognosis and/or therapy of these groups differ substantially: group 1 with stage IA gastric cancer $(n=17)$, group 2 with stage IB to IV gastric cancer $(n=27)$, and group 3 with gastric lymphoma $(\mathrm{n}=6)$.

Table IX.1 Scales of the "Freiburger Fragebogen zur Krankheitsweratbeitung (FKV 102) and examples of some items

\begin{tabular}{|c|c|c|c|c|c|c|}
\hline \multicolumn{2}{|c|}{ Scales of the FKV 102} & \multirow{2}{*}{ 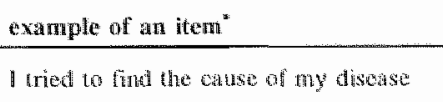 } & \multicolumn{2}{|c|}{ ratinge } & \multirow{2}{*}{$\frac{\text { neanin }}{39}$} & \multirow{2}{*}{$\frac{8}{12}$} \\
\hline 1 & Problem analysis \& probiem solving & & 13 & 65 & & \\
\hline 2 & Depression & 1. was depressed \& sad & 16 & 80 & 34 & 16 \\
\hline 3 & Hedonism & I did somenhing nice tollay & 11 & 55 & 32 & 9 \\
\hline 4 & Religion \& search lor reason & Through the discase, I tom mysed & 8 & 40 & 19 & 8 \\
\hline 5 & Pessmisto behavioum \& distrustullness & Ifelf dominated tyy the dociors & 7 & 35 & 18 & 7 \\
\hline 6 & Cognitive denial \& dissimulation & I wanted to hear that it was not that bot & 9 & 45 & 22 & 8 \\
\hline 7 & Distraction \& self-appraisal & 1 tried to forget & 8 & 40 & 21 & 7 \\
\hline 8 & Emolional control \& social isolation & I wanted to be allone & 7 & 35 & 18 & 6 \\
\hline 9 & Regressive lendency & I wished that I were allowed to be weak & 5 & 25 & 10 & 4 \\
\hline 10 & Relativation by comparison & 1 got strongth, buca ise other lined & 4 & 20 & 14 & 4 \\
\hline 1: & Compliance strategy \& trust in doctors & I did exactly what roy dochon cold the & 4 & 20 & 17 & 3 \\
\hline 12 & Sell-support & I rotied on my optimistm a dust for life & 5 & 25 & 18 & 5 \\
\hline
\end{tabular}

* Translation from the German by the awthor: 'mean values and standart deviation (S) for a disease eondrol group? ascording to Mutbuy et al. ${ }^{35}$

\section{Statistics}

The specific scales of the FKV 1.02 were compared with each other by means of a Wilcoxon Matched-Pairs Signed-Ranks Test with a Bonferroni correction. A pvalue of $0.013(0.05 / 4)$ was used to indicate significance. The possible influence of five variables on coping strategies was analysed in linear regression models with a Bonferroni correction. The time past operation was transformed into the logarithmic value $\left(\log _{10}\right)$ to account for the skewed distribution of the values. A pvalue of $0.004(0.05 / 12)$ was used to indicate significance.

\section{Results}

Fifty of the 78 patients $(64 \%)$ agreed to be interviewed by the clinical psychologist. These paiients $(\mathrm{f}=19, \mathrm{~m}=31 ; \mathrm{f} / \mathrm{m}=0.62)$ with a median age of 53 years (IQR 49-63) were investigated 187 days (IQR 41-573) after the total gastrectomy.

The overall coping patterns are given in Figure IX.1 as the percentage of the maximum possible value for each individual coping pattern. The pattern compliance 
strategy and trust in doctors scored significantly higher than all the other fields $(p<0.0001)$. The patterns self-support and relativation by comparison had significantly higher ratings than all the other fields $(p=0.0001)$ with the exception of the field compliance strategy and trust in doctors. Problem analysis and problem solving and hedonism scored significantly higher $(\mathrm{p}=0.0003)$ than cognitive denial and dissimulation or the remaining seven fields.

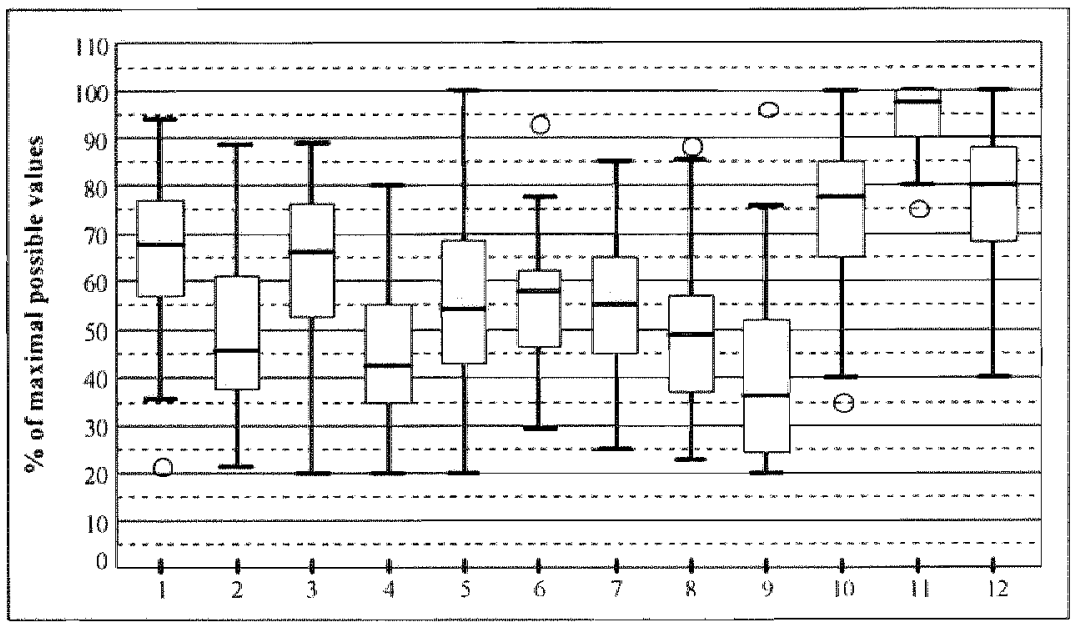

Figure IX.1 Coping patterns after curative total gastrectomy. Given is the distribution of the percentages of the maximal possible values for the 12 coping patterns in 50 patients after curative total gastrectomy in a whisker-boxplot. The lower boundary of the boxes is the $25^{\text {in }}$ percentile, the upper boundary is the $75^{\text {th }}$ percentile, the line in the box represents the mediam. The circles denote outliers, which are defined as cases with a value 1.5 to 3 box-lengths from the edge of the box. The whiskers show the highest and lowest values that are not outliers. $1=$ problem analysis and problem solving, 2 =elepression, 3 =hedonism, $4=$ religion and search for reason, $5=$ pessimistic behaviour and distrustfullness, $6=$ cognitive denial and dissimulation, 7 =distraction and self-appraisal, 8=emotional control and social isolation, $9=$ regressive tendency, $10=$ relativation by comparison, $11=$ complance strategy and trust in doctors, $12=$ sell-support.

The number of patients with values below or above the mean values $(+/-$ standard deviation) of a disease-control group ${ }^{35}$ is given in Table IX.2. The fiellds compliance strategy and trust in doctors, hedonism, regressive tendency, relativation by comparison and self-support had at least ten patients $(20 \%)$ above the mean score of the disease-control group, whereas only the field emotional control and social isolation had ten patients below the mean of the disease-control group. 


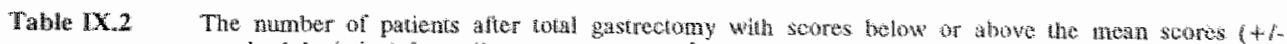
standard deviation) for a discasemcontrol group"

\begin{tabular}{|c|c|c|c|c|c|}
\hline \multicolumn{2}{|c|}{ Scales of the FKV 102} & \multicolumn{2}{|c|}{ <. mesn of disease controls } & \multicolumn{2}{|c|}{$>$ mescate of disinasio controls } \\
\hline & & th & $\%$ & $\mathrm{n}$ & 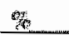 \\
\hline 1 & Problem analysis \& problem solving & 4 & 8 & 8 & 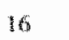 \\
\hline 2 & Depression & $\S$ & 10 & 7 & 14 \\
\hline 3 & Hedonism & 5 & 10 & 13 & $2 \overline{6}$ \\
\hline 4 & Religion a search for reason & 5 & 10 & 7 & 14 \\
\hline 5 & Pessimistic behaviour distrustulfulness & 5 & 10 & 8 & 16 \\
\hline 6 & Cogrütive derial dissimndlation & 1 & 2. & 4 & 8 \\
\hline 7 & Distraction \& self-appraisal & 6 & 12 & 8 & 16 \\
\hline 8 & Emctional control sancial isolation & 10 & 20 & 7 & 14 \\
\hline 9 & Regressive tendenoy & 9 & 18 & $\mathbb{1}$ & 22 \\
\hline 10 & Relativation by comparison & 4 & 8 & 10 & 20 \\
\hline 11 & Complance strategy a trust in doctors & 0 & 0 & 23 & 46 \\
\hline 12 & Selissuppor. & 2 & 4 & 10 & 20 \\
\hline
\end{tabular}

acoordimg to Muthuny ${ }^{35}$

The patients with stage IA cancer did not differ in any of the twelve coping parameters compared with the patients with a worse cancer stage (IB to IV). Cancer patients and those with gastric lymphoma differed in the field emotional control and social isolation which was slightly higher in the group with the lymphomas compared to the cancer patients $(p=0.004)$. Whilst this might be due to the difference in therapy (e.g. chemo-therapy), the small size of the lymphomagroup $(n=6)$ limits the usefulness of this finding. There was a positive correlation of the field hedonism with time past operation in a linear regression model $\left(r^{2}=0.5, p<0.0001\right.$, Figure IX.2). Neither gender, weight loss nor energy intake per kilogram body weight and day were associated with any specific coping pattern.

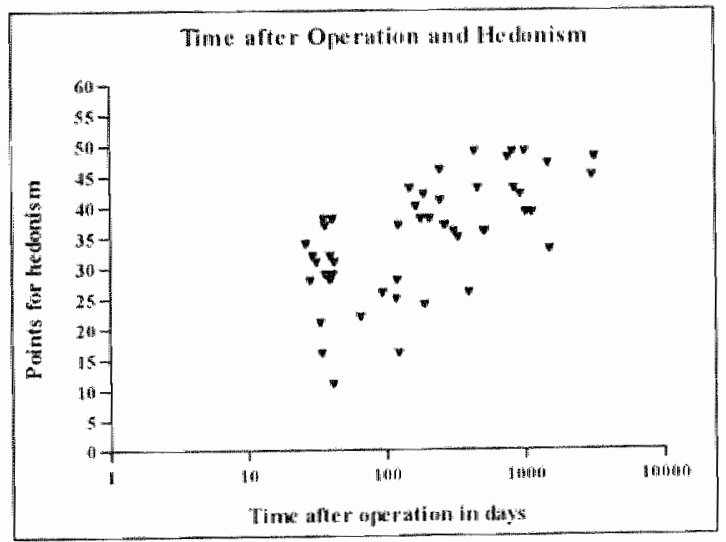

Figure $\mathbb{1 X} .2$ The influence of time past operation on the degree of hedonisic coping. Given is the relationship of the time past operation (logarithmic scale) and the rating for hedonistic coping in 50 patients after curative total gasurectomy. $r^{2}=0.5 p<0.0001$ 


\section{Discussion}

Whilst the importance of successful and unsuccessful coping strategies for the patient's well-being is recognised, it is not well understood why some patients succeed in their coping process whereas others fail. A predilection for certain coping strategies after or during disease can be due to sociodemographic factors, personality traits, situational factors, and characteristics of the disease and/or therapy. As there seems to be a difference in coping patterns between various disorders, it is tempting to ask whether objective differences within one condition (prognosis, severity, chronicity, symptoms, etc.) influence the choice of certain coping strategies.

In this study we described coping behaviour of patients with gastric malignancy after curative total gastric resection and tried to relate it to a number of preselected disease-related parameters. Only the most plausible variables were examined, because of the small number of patients. Besides tumour stage and tumour type as well as time elapsed since operation and gender, we choose to evaluate weight loss since operation and current energy intake per kilogram body weight and day. Weight loss and low energy intake are very common problems after total gastrectomy. Age, which sometimes seems to be of influence on coping patterns ${ }^{16,17}$, was not considered as an interesting variable, as the range of age in our patient group was very narrow.

This study is a rather crude assessment of trends as the number of patients examined was small in relation to the number of evaluated parameters. Moreover, the selection bias created by the decision of $36 \%$ of the patients not to accept the invitation of the psychological assessment is of unknown impact.

Comparing the individual scales with each other and with the values of a diseasecontrol group ${ }^{35}$, a predilection for certain coping patterns in our patients can be discussed.

Compliance strategy and trust in doctors reflects the positive experience of surviving a life-threatening disease by medical intervention without major complications, free of recurrences, and without major post-operative chronic impairment. In our patient group, a great number of patients had higher ratings for this strategy compared to the disease-control group, although patients with chronic renal insufficiency or coronary insufficiency have a predilection for this pattern thernselves ${ }^{30}$. This probably is due to the impression of our patients that they were saved, but may partly be due to the difference in chronicity or to the difference in daily disease-related problems between our patients and the disease-control group. Hedonism describes the patients, interest and self-study of dietary habits, digestion, bowel movements, enjoyment of life and well-being. In contrast to the field problem analysis and problem solving, which is a more theoretical approach, the term hedonism covers the concept of focusing on minor improvements in the 
culinairy field. It is remarkable but also understandable that patients, whose major handicap is enjoying eating, apply this technique in such a frequency especially whem compared to the disease-control group.

Looking at the results of the intra-scale analysis, regressive tendency, an intrapsychic retreat of the patient to cope without external support, was not one of the major coping patterns of our patients. This is consistent with the high scores for the pattern discussed. so far, which all indicate a rather active role of the patient. However, compared to the disease-control group of Muthny ${ }^{35}$, a relatively large proportion of our study group applied this coping technique.

Self-support describes the patients possibility of overcome monents of suspicion and depression and to notice objective improvements in disease parameters.

Relativation by comparison probably is a highly attractive coping pattern to patients after curative total gastrectomy, because they survived while others died.

It is positive that the field problem analysis and problem solving is a major feature of patients after gastric resection. Many patients seem to have realised, that own assessment of disease- and operation-related problems, e.g. food intolerance, and the initiative to adapt accordingly are necessary prerequisites to improve their quality of life. The realisation that they can actively influence their post-operative problems is of importance as it examplifies regained self-determination. The setting of our study in a rehabilitation centre, where patients come to learn how to adapt, might have overemphasised the importance of this specific coping pattern. Compared to the disease-control group, however, the number of patients with higher ratings was not impressive.

Emotional control and social isolation was applied less often by our patients than by the disease-control of Muthny et al ${ }^{35}$, which is consistent with the active role of the patient indicated by the use of the patterns discussed up to now.

Evaluating the influence of some pre-selected variables on the predilection for coping patterns, most variables had no effect. Patients with different cancer stages corresponding to a highly varying prognosis applied similar coping strategies. Whilst this could indeed indicate that coping patterns in one specific disease are independent of prognosis, this is most probably due to lack of information about the varying prognosis or the trust that curative resection removes this variation. Only the time past operation showed a positive correlation with the importance of hedonistic coping, indicating a "learning process".

In conclusion, active and problem-oriented coping patterns were predominant in a group of cancer-free patients after total gastrectomy for gastric malignancy. If these coping patterns are recognised by the managing physician(s), post-operative rehabilitation can probably be further improved. 


\section{References}

1. Sue-Ling HM, Johnston D, Martin IG, Dixon MF, Landsdown MRI, McMahon MJ, Axon ATR. Gastric cancer: a curable disease in Britain. BMJ 1993;307: $591-595$

2. Maruyama K, Sasako M, Kinoshita T, Sano T, Katai H. Surgical treatment for gastric cancer: the Japanese approach. Semin Oncol-Gastric Cancer 1996:23:360 368

3. Hanazaki K, Sodeyama $H$, Wakabayashi $M$, Miyazawa M, Yokoyama S, Sode $Y$, Kawamura N, Miyazaki T, Ohtsuka M. Surgical treatment of gastric cancer detected by mass screening. Hepato Gastroenterology 1997;44:1126-1132

4. Troidl H. Lebensqualitât: ein relevantes Zielkriterium der Chirurgie. Chirurg $1989 ; 60: 445-449$

5. Bozzetti F. Total versus subtotal gastrectomy in cancer of the distal stomach: facts and fantasy. Eur ISurg Oncol 1992;18:572-579

6. Buhl $K$, Lehnert $T$, Schlag $P$, Herfarth $C$. Reconstruction after gastrectomy and quality of life. World J Surgery 1995; 19:558-564

7. Roder JD, Stein HJ, Eckel F, Herschbach P, Henrich G, Böttcher K, Busch R, Siewert JR. Vergleich der Lebensqualitat nach subtotaler und totaler Gastrektomie beim Magenkarzinom. Disch Med Wochenschr 1996;121:543-549

8. Schwarz $A$, Büchler $M$, Usinger $K$, Rieger $H$, Glasbrenner $B$, Friess $H$, Kunz $\mathbb{R}$, Beger HG. Importance of the duodenal passage and pouch volume after total gastrectomy and reconstruction with the Ulm pouch: prospective randomized clinical study. World J Surg 1996;20:60-67

9. Swedlund J, Sullivan M, Liedman B, Lundell L, Sjodin I. Quality of Life after Gastrectomy for Gastric Carcinoma: Controlled Study of Reconstructive Procedures. World J Surg 1997;21:422-433

10. Troitl H, Kusche J, Vestweber JH, Eypasch E, Maul U. Pouch versus oesophagojejunuostomy after total gastrectomy: A randomized clinical trial. World J Surg $1987 ; 11: 699-712$

11. Fuchs KH, Thiede A, Engemann R, Deltz E, Stremme O, Hamelmann H. Reconstruction of the food passage after total gastrectomy: randomized tral "World J Surg 1995; 19:698-705

12. Brägelmann R, Armbrecht U, Rosemeyer D, Schneider B, Zilly W, Stockbrügger RW. Total Gastrectomy: The Influence of Preserved Duodenal Transit and of Pouch Reconstruction on Abdominal Symptoms, Nutrient Assimilation, and Medico-Social Functioning. Gierman J Gastroenterology 1996;9:555

13. Shapiro DE, Rodrigue JR, Boggs SR, Robinson ME. Cluster analysis of the medical coping modes questionnaire: evidence for coping with cancer styles? J Psychosom Res 1994;38:151-9

14. Baider L, Perry S, Sison A. Holland J, Uuziely B. DeNour AK. The role of psychological variables in a group of melanoma patients. An Israeli sample. Psychosomatics $1997 ; 38: 45-53$ 
15. Graupe F, Schwenk W, Bracht B, Kroner-Herwig B, Stock W. Psychological stress on patients in tumor after-care after RO resection of colorectal carcinomas. Chirung 1996:67:604 609

16. Gross RE, Burnet CB, Borelli M. Coping responses to the diagnosis of breast cancer in postmastectomy patients. Cancer Pract 1996:4:204-211

17. Jacobson PB, Butler RW. Relation of cognitive coping and catastrophizing to acute pain and analgesic use following breast cancer surgery. $₫$ Behav Med 1996; 19:17-29

18. Hulme Moir I. Psychological, social, and surgical factors which influence success or failure after gastric operations. Scand J Gastroenterol 1979;14:457-462

19. Wagner MK, Armstrong D, Laughlin IE. Cognitive determinants of quality of life after onset of cancer. Psychol Rep 1995:77:147-54

20. Barkwell DP. Ascribed meaning: a critical factor in coping and pain attenuation in patients with cancer-related pain. I Pallat Care 1991;7:5-14

21. Faller $H$, Lang $H$, Schilling $S$. Causal "cancer personality" atribution- an expression of maladaptive coping with illness? Z Klin Psychol Psychopathol Psychther 1996;44:104-116

22. Feifel H, Strack S, Nagy VT. Degree of life-threat and differential use of coping modes. I Psychosom Res 1987;31:91-99

23. Spiegel D. Health caring. Psychosocial support for patients with cancer. Cancer $1994 ; 74: 1453-7$

24. Cunningham AJ, Lockwood GA, Edmonds CV. Which cancer patients benefit most from a brief, group, coping skills program? Int J Psychiatry Med 1993;23:383-398

25. Finlay IG, Jones OL. Hypnotherapy in palliative care. I R Soc Med 1996;89: 493-496

26. Grahn G, Danielson M. Coping with the cancer experience. Il. Evaluating an education and support programme for cancer patients and their significant others. Eur J Cancer Care Engl 1996:5:182-187

27. Grassi L, Rosti G. Psychosocial morbidity and adjustment to illness among longterm cancer survivors. A six-year follow-up study. Psychosomatics 1996:37: $523-532$

28. Holland JC, Korzun AH, Tross S, Silberfarb P, Perry M, Comis R, Oster M. Comparative psychological disturbance in patients with pancreatic and gastric cancer. Am J Psy 1986;143:982-986

29. Theissen HH. Coping with illness in the postoperative phase following gastrectomy. Z Gastroenterol 1996;34 Supp $12: 29-31$

30. Muthny FA, Bechtel M. Spaete M. Lay etiologic theories and coping with illness in severe physical diseases. An empirical comparative study of female myodardial infarct, cancer, dialysis and multiple sclerosis patients. Psychother Psyshosom Med Psychol 1992;42:41-53

31. Dunkel-Schetter D, Feinstein LG, Taylor SE, Falke RL. Patterns of coping with cancer. Health Psychol 1992;11:79.87

32. Beutel M. Bewältigungsprozesse bei chronischen Erkrankungen. Edition Medizin VCH. Weinhem 1988 
33. Classen C, Koopman C, Angell K. Spiegel D. Coping styles associated with psychological adjustment to advanced breast cancer. Health Psychology $1996: 15: 434-437$

34. Svedlund J, Sullivan M, Sjodin I, Liedman B, Lundell L. Quality of life in gastric cancer prior to gastrectomy. Qual Life Res 1996;5:255-264

35. Muthny FA. Freiburger Fragebogen zur Krankheitsverarbeitung. Manual. Verlag Bellz, Weinheim 1989 


\section{Chapter X}

\section{General Discussion}

R Brägelmann, RW Stockbrügger 


\section{General Introduction}

\section{Introduction}

The cardinal medical problem of a patient with gastric cancer is to be suitable for a curative resection. Nothing else matters at that moment. After curative resection, the threat of recurrence has the greatest significance for the patients. However, "functional changes" in their daily post-operative lifes gain more importance, too. In this context the term "functional changes" encompasses medical, psychological and social parameters.

Advances in diagnosis ${ }^{1-12}$ and surgical technique ${ }^{1.2 .13-22}$ caused a rise of curative resection and of survival rates. Although stomach cancer incidence is decreasing, the number of surviving patients with a total gastrectomy for gastric malignancy will remain around the present level for quite a time, because of the improved survival. Furthermore, the rise in proximally located gastric tumours also causes an increase of total or subtotal gastrectomies ${ }^{23-26}$. In summary, the number of patients for whom long-term post-operative problems after total gastrectomy will be relevant, will probably rise.

In Chapter I some features of the situation after total gastrectomy as described in the literature have been discussed. It is pointed out that there are a number of possibly or definitely interrelated factors which determine post-operative symptomatology, nutrient assimilation, and medico-social performance. Although the number of studies performed on tunctional changes in patients after total gastrectomy is quite high, the data is conflicting in many aspects. Furthermore, information on the relevance of specific alterations after total gastrectomy is often lacking. The most important reasons for discrepancies and shortcomings of information are the following problems:

1. Recruiting an adequate number of representative patients for a study like this is hampered by the poor prognosis of this patient group.

2. A great number of potentially confounding variables have to be evaluated simultaneously after numerous intensive investigations in a large study group using multivariate analysis.

In what follows our results will first be discussed with a descriptive approach. Thereafter, an outline will be given what insights our investigations provide into the pathophysiology of nutrient malassimilation after total gastrectomy, and in the factors influencing post-operative medico-social performance.

\section{Descriptive analysis}

Looking at the data of the large patient group presented in Chapter III and Chapter VIII, the overall impression is that "very little has changed in their the 
patients) lives (after total gastrectomy) ${ }^{m y}$. This general statement, although true, needs some specific comments.

Due to the selection procedure as described in Chapter $\mathbf{I}$, the patients constitute a subgroup of gastric cancer patients with a much better prognosis than the total group of operated gastric cancer patients. However, this selection was intended for this special investigation: namely to study nutrient malassimilation, related symptomatology and possible intervention in a (supposedly) cancer-free patientgroup relatively stable after the curative surgical event.

It is probable that adaptive processes occur after total gastrectomy. As there is little information regarding the influence of the time span since operation on this process, it is not possible to define when the adaptive phase after total gastrectomy is ended. Also, the length of an adaptive phase might be different for different parameters. The time span after operation in our patients varied to a great extent, ranging from admission in the first months after operation to years. This feature of our patient population offered the opportunity to include time span affer operation as a variable of interest. Indeed, there were some variables which were timedependant; such as ferritin values, medico-social functioning, and the degree of hedonistic coping.

Symptoms were reported with a frequency comparable to the literature. It is noteworthy that this applies to the situation on admission to a rehabilitative centre reflecting symptoms at home as well as symptoms under controlled dietary conditions. According to their own assessment, the hindrance of the patients by these symptoms seems to be low.

Meteorism was significantly more frequent in patients with rapid oro-coecal transit than in those with normal transit time (Chapter VI). Colonic bacterial fermentation of malabsorbed carbohydrates with subsequent gas production is the probable explanation for this. There was notably no difference between patients with and without small bowel bacterial overgrowth with regard to meteorism (Chapter VII). Dyspepsia, a relatively vague denomination for upper GI-symptoms can have a multitude of causes, either alone or in combination. Pancreatic insufficiency is one of the possible causes. Our intervention study with a high dosage of pancreatic enzymes did, however, not show any improvement of dyspeptic complaints (Chapter V). Neither was there any correlation between dyspepsia and rapid orocoecal transit time (Chapter VI), as it is discussed as a possibility in the literature $^{28}$. In our view, the pathophysiology of dyspepsia after total gastrectomy, still remains unexplained.

Early satiety after gastrectomy is a common problem. The concept of a pouch construction was introduced to overcome the volume-problem after gastric resection. In our data (Chapter IV) the construction of a pouch did not have any effect on calorie intake. 
Twenty-six percent of the patients had reflux complaints and alkaline reflux oesophagitis as diagnosed at endoscopy. This figure is compatible with the data from the literature ${ }^{29.30}$, but it might overestimate the true frequency of oesophagitis as patients with available endoscopic records had more often reflux complaints. Treatment for intestinal reflux into the oesophagus after total gastrectomy is difficult as the reflux is alkaline by nature. The construction of a Roux-en- $Y$ segment with a 40 to $50-\mathrm{cm}$ long segment proximal of the entero-enteroanastomosis most often is the only solution ${ }^{31}$. As is described in Chapter $\mathbf{I V}$, the construction of a pouch did not significantly decrease the frequency of reflux oesophagitis. On the contrary, there was a non-significant trend to more oesophagitis in the pouch group. The notion that pouches can cause more alkaline reflux oesophagitis has been described by others $t o 0^{32,33}$.

Dysphagia after total gastrectomy can be due to a fibrotic stenosis of the anastomosis or to an inflammatory stenosis in reflux patients; or both. While the former can be treated locally with dilatation, the latter faces the same problems as the reflux patient.

Haematological and biochemical data were only moderately disturbed which is in accordance with most other studies. As is known from the literature, supplementation with vitamin $B_{12}$, iron and folic acid will efficiently prevent anaemia. In this context it is striking that 138 of our 1.74 patients $(79 \%)$ did not have iron supplementation on admission. In these patients moderate anaemia was found in $48.6 \%$ and sideropenia in $26.7 \%$. Vitamin $\mathrm{B}_{12}$ supplementation on the other hand, had been given to 126 of 173 patients (72\%). Seemingly, the need for iron supplementation after total gastrectomy needs to be stressed more.

Dietary advice after operation had been given to only $63 \%$ of the patients. However, the number of meals per day exceeded three in 90 percent of the cases with 75 percent having even five or more meals a day. This indicates that a large proportion of the patients have found out themselves how and what to eat. Under hospital conditions in the three clinical rehabilitation centres the median energy intake was 37.8 kilocalories per kilogram body weight and day. This is only five percent below the energy intake considered to be ideal for patients after total gastrectomy (40 kilocalories per kilogram body weight and day) ${ }^{34}$. Assessing simultaneously the symptoms and the calorie intake, our data suggest that patients after total gastrectomy can eat enough to cover their daily energy requirements without provoking severe abdominal symptoms.

Most of our patients did not report suffering from diarrhoea. Objectively, frequency of bowel movements and faecal consistency were normal in most patients. The slightly elevated faecal mass was normally not even noticed by most patients. The patients produced stools of relatively low volume with a relatively high fat output due to a median fat malabsorption of 11.6 percent (IQR 5.1-1.9.6). However, it is important to note that the range of fat malabsorption was five to 80 
percent. This is comparable to what is found in the literature (Chapter I, Table 1.5).

Evaluating three different types of reconstruction after total gastrectomy (Chapter IV) no differences in symptomatology, clinical signs, nutrient malassimilation, and post-operative performance could be found. Our data, therefore, do not support a preference for any single mode of reconstruction after total gastrectomy for gastric cancer.

Using the $\mathrm{H}_{2}$-breath test with radiopaque markers the mean oro-coecal transit time for the whole study group was 202 minutes (SEM 4). This is only 17 percent faster than for normal healthy controls. Similar results have been found by Miholic 35 , who recorded a median small bowel transit time of 200 minutes in 61 patients after curative total gastrectomy with a scintigraphically controlled test meal. Pellegrini et al. even found a slower transit in operated than in not-operated patient $s^{36}$. In $21.7 \%$ of our patients, however, oro-coecal transit time was shorter than 75 minutes. In this subgroup of patients steatorrhoea was significantly higher than in the remaining majority of patients.

$37.7 \%$ of the evaluated patients showed signs of bacterial overgrowth of the upper intestine when evaluated with the $\mathrm{H}_{2}$-breath test. It is quite difficult to compare this number with existing studies, because data are rather scarce and the reported frequency of bacterial overgrowth varies widely (Chapter I, Table I.8). Furthermore, there is the possibility that patients with rapid oro-coecal transit time, in whom the $\mathrm{H}_{2}$-breath test is not applicable for the evaluation of bacterial overgrowth, additionally also had bacterial overgrowth. There were no differences in symptoms, clinical signs, and nutrient assimilation between patients without and patients with small bowel bacterial overgrowth. Thus it seems that the complaints of patients after gastrectomy are not due to bacterial overgrowth and that the postoperative achlorhydric state does not necessarily cause a bacterial overgrowth syndrome. This is compatible with the literature ${ }^{37-40}$.

Weight loss, either pre-operatively $(9.2 \%$ of the weight in health) and postoperatively $(8.7 \%$ of the weight in health) was in the range reported by other authors (Chapter I, Table I.1). Since most of the patients were slightly overweight in health, this weight loss resulted in a more "normal weight" on admission. The proportion of underweight patients (BMI $<20.0 \mathrm{~kg} / \mathrm{m}^{2}$ ) was only $25 \%$.

Many patients and physicians still consider total or subtotal gastrectomy and the post-operative changes a catastrophe. This notion is not correct. Our data suggests, that gastrectomy as such does not interfere with good post-operative performance as long as there is no remaining malignant disease. Medico-social functioning (Chapter VIII) was evaluated with the Edinburgh Rehabilitation Status Scale (ERSS). On admission the whole group of patients had a median ERSS-score of four (IQR 2 to 6 ) with a range from zero to 17 on a scale from zero to 28 points. Our patients thus scored much better than many other patient groups with chronic 
diseases, (even such benign conditions as chronic back pain ${ }^{41}$ ), suggesting that patients after a curative total gastrectomy potentially can perform quite well. However, there are a couple of possible biases to be kept in mind: 1) The positive impression might be caused by the positive selection of our patient group. 2) Another reason for the low score on the ERSS might be, that the ERSS seems to emphasise the importance of mobility by evaluating independence, activity, and isolation. Hampered mobility, however, is most often not a problem of gastrectomised patients.

Whilst the importance of successful and unsuccessful coping strategies for the patient's post-operative behaviour is well recognised, is not sufficiently understood why some patients succeed in their coping process whereas others fail. Some coping strategies are reported to correlate with better adjustment and less emotional distress than others ${ }^{42-46}$. A predilection for certain coping strategies during or after disease can be due to sociodemographic factors, personality traits, situational factors, and characteristics of the disease and/or its therapy. Reports about diseasespecific coping patterns in patients with different diseases ${ }^{47.50}$ were the reason to examine coping patterns in patients after curative total gastrectomy (Chapter $\mathbf{I X}$ ).

The primary aim was to give a description of coping patterns in this specific patient group. Furthermore, we tried to assess the influence of some objective diseasespecific parameters on the patients" "choice" of coping patterns. However, this study should only be seen as a rather crude assessment of trends, as the number of patients examined was small and the number of evaluated parameters relatively high.

A comparison of the twelve examined coping patterns within the patient group, as well as a comparison with a disease-control group from the literature ${ }^{48}$ revealed that our patients mainly followed active and problem-oriented coping patterns. In the context of post-operative dietary problems, it is quite interesting that the pattern hedonism is frequently applied by our patients. With an increasing time span after the operation, patients appear to "learn" how to enjoy eating again. It might be, that the positive experience of doing something that was particularly hampered by the disease, emphasises the regained health. All other examined parameters were of no influence on the patients' choice of coping patterns.

\section{Factors influencing nutrient malassimilation after total gastrectomy}

In the following paragraph two possible causative factors of nutrient malassimilation after total gastrectomy and their putative pathophysiology will be discussed. 


\section{Energy intake}

Median energy intake in our patients under clinical conditions was sufficient. Metabolic problems due to a diet five percent below the standard requirements are not probable. However, under uncontrolled conditions and without "motivation" by the clinical setting, dietary intake might be lower. Bradley et al. "51 reported a 15 percent lower intake at home compared to an examination under hospital conditions in ten patients. It is very striking that in our study group patients suffering from greater weight loss seemed to consume more calories per $\mathrm{kg}$ body weight as a conscious or subconscious reaction.

As is mentioned above, abdominal symptoms do not seem to be much of a handicap to the patients subjectively. Objectively, however, the frequency and the severity of early satiety were associated with lower energy intake, as was the frequency of vomiting. Symptom-induced low calorie intake has also been mentioned by Harju et al. ${ }^{52}$.

The idea of a pouch construction after total gastrectomy was prompted by the concept of an anatomical volume problem inducing early satiety. In our patient group, the construction of a pouch did not increase the energy intake nor did it decrease the frequency of early satiety. According to our data, there is no necessity to construct a pouch to improve energy intake.

\section{Maldigestion and/or malabsorption}

Calculating the energy loss through steatorrhoea, the average fat malabsorption is only of little influence on energy requirements. However, the range of the fat malabsorption was five to $80 \%$, pointing to clinically relevant individual differences. The influence of steatorrhoea on the deficiency of fat soluble vitamins was not addressed in this thesis, but should be kept in mind as well. Therefore, assessment of fat malabsorption in the individual patient is necessary when evaluating patients after total gastrectomy for nutrient malassimilation.

Patients after total gastrectomy produce stools of relatively low volume with a high fat content. This type of a steatorrhoea is less likely to be caused by small bowel bacterial overgrowth but resembles more the type following pancreatic insufficiency. Pancreatic exocrine deficiency can be absolute (organ insufficiency) or relative (non-availability of digestive enzymes). In what follows I will comment on these possibilities in the context of the studies presented.

It seems improbable, that absolute pancreatic insufficiency, often referred to as primary pancreatic insufficiency, is the cause of chronic post-gastrectomy steatorrhoea. In the intervention study (Chapter $\mathbf{V}$ ) the effect of a ligh dosage of pancreatic enzymes was examined in a subgroup of patients with moderate to severe steatorrhoea after total gastrectomy. Supplementation with pancreatic enzymes in a dosage of lipase 72.000 , amylase 54.000 , protease $4.800 \mathrm{FIP}$ per 
every major meal and half of it per every smaller meal did not significantly increase fat absorption. It is not reasonable to assume that this is a dosage problem, as the prescribed amount of lipase was more than double of what is used for exocrine pancreatic insufficiency in chronic pancreatitis ${ }^{53}$. Friess et all. ${ }^{54}$ described a primary pancreatic insufficiency after total gastrectomy in nine patients who had been operated three month before. However, adaptation of the pancreas to the postoperative state during time might be of importance for the interpretation of the data. Büchler et al.$^{55.56}$ described an increase of the enzyme content of the pancreas in rats after gastrectomy which took longer for lipase than for other enzymes. In a previous study of our group, a positive correlation of faecal fat output and faecal chymotrypsin output was described in patients after partial and total gastrectomy indicating a positive feedback mechanism of steatorrhoea on the pancreas ${ }^{\text {s7 }}$.

Relative pancreatic insufficiency can theoretically be caused by the bypass of the duodenum, bacterial overgrowth of the small intestine, rapid transit of food through the small intestine with poor mixing of food and enzymes, or a negative feedback mechanisms of the ileum on the exocrine pancreas elicited by the presence of fat or carbohydrates $^{58}$. Most of these mechanisms were investigated in this study.

In Chapter IV, patients with and without surgical duodenal bypass were evaluated. There was no difference in the degree of steatorrhoea between the patient groups examined. Fuchs et al ${ }^{59}$ had similar results. This renders it less probable that duodenal bypass is the reason for steatorrhoea.

The influence of bacterial overgrowth of the small bowel was examined in Chapter VII. Steatorrhoea in small bowel overgrowth and subsequent malabsorption of fat soluble vitamins is probably due to a deficiency of conjugated bile acids ${ }^{60.61}$, possibly also to a toxic effect of deconjugated bile acids on jejunal mucosa ${ }^{62.63}$, and/or due to relative pancreatic insufficiency with bacterial degradation of pancreatic enzymes as mentioned above. In our study we could not find any differences between patients with and patients without small bowel bacterial overgrowth regarding nutrient malassimilation. Bacterial overgrowth, therefore, seems not to influence steatorrhoea in our patients.

In Chapter VI patients with an oro-coecal transit time below 75 minutes were compared with those with a slower transit. Rapid oro-coecal transit was indeed associated with significantly higher degree of steatorrhoea and with a lower faecal chymotrypsin concentration. Since faecal chymotrypsin output per 72 hours was not significantly different, pancreatico-cibal asynchrony seems to have the most important role in steatorrhoea after total gastrectomy. If pancreatico-cibal asynchrony is the major reason for steatorhoea in patients with accelerated small bowel transit, measures to slow down small-intestinal transit - with or without pancreatic enzyme supplementation - would be a logical approach. 


\section{Conclusion}

Symptom-induced low calorie intake and pancreatico-cibal asynchrony acting either alone or in concert seem to be the major reasons for mutrient malassimilation in patients after total gastrectomy.

\section{Factors influencing medico-social performance after total gastrectomy}

As has been discussed above, patients after total gastrectomy suffer from numerous, but not necessarily severe, problems. The question arises which of the various phenomena has a major impact on post-operative performance. Studying specific pre- and post-operative variables with regard to their influence on medicosocial functioning after total gastrectomy might elucidate areas where preventive or therapeutic action could be useful. The influence of a number of them on medicosocial functioning is discussed in Chapter VIII.

It seems as if the social background of the patients is of importance for the degree of disturbance experienced by them post-operatively. The patients of the clinical centre that served mostly blue-collar workers had higher ratings on the ERSS-score than the patients of the two other centres. It is, however, not evident what caused this difference. It is not very probable that it is caused by inter-rater variability, because the inter-rater reliability of the ERSS is reported to be very good ${ }^{41}$. The impact of physical ability may be different for the conception of "good health" between the two patient groups, either because of differing patterns of body selfesteem and/or because of differing influence of the post-operative state on the working situations. Psychological counselling might be of use in the former case and social advice regarding possible changes in working life in the latter.

Our data suggest that medico-social functioning after total gastrectomy improves with time after operation probably due to recovery after the operation and physical, psychological, and social adaptation to the post-operative situation. Zieren et al. ${ }^{64}$ had similar results. This certainly is true only for the selection of tumour-free survivors in this study, in whom the factor of increasing "hope for the future" may have an important impact. The analysis of the coping patterns in Chapter $\mathbf{L X}$ is consistent with the impression of psychological adaptation. It points to increasing use of hedonism with increasing time past operation. This observation has be to regarded with caution, however, because of the small sample size.

Symptoms of dyspepsia, dysphagia, and reflux into the oesophagus had a major impact on medico-social performance after total gastrectomy, although they were not necessarily the most frequent events. The influence of dysphagia and reflux on the ERSS is reflected by a positive correlation between the severity of pathological findings at upper intestinal endoscopy and the ERSS-score (Chapter VIII, Figure 3). Here also the interpretation has to be cautious, because the number of patients with severe endoscopic findings was small and the range of the corresponding 
ERSS-scores was wide.

Using the more complex statistical approach in Chapter VIII the relationship of small bowel bacterial overgrowth and ERSS-scores as described in Chapter VII was not found anymore.

\section{Conclusion}

In order to improve the medico-social functioning of patients after total gastrectomy physical findings, psychological factors, and the social situations of the patient should be jointly assessed and - if necessary - influenced by a team approach of various professions. Rehabilitative centres may be an ideal environment for this task, as they have the advantage of a specific medical, medico-social, and psychological expertise in combination with a special emphasis on the evaluation and the treatment of chronic medical problems when compared to the standard inpatient or outpatient setting. 


\section{References}

1. Brennan MF, Karpeh MS Jr. Surgery for gastric cancer: The American view. Semin Oncol-Gastric Cancer 1996;23:352-359

2. Sue-Ling HM, Johnston D, Martin IG, Dixon MF, Landsdown MRJ. McMahon MJ, Axon ATR. Gastric cancer: a curable disease in Britain. BMJ 1993;307:591595

3. Maehara Y, Tomoda M, Tomisaki S, Ohmori M, Baba H, Akazawa K, Sugimachi K. Surgical Treatment and Outcome for Node Negative Gastric Cancer. Surgery $1997 ; 121: 633-639$

4. Jatzko G, Lisborg $\mathrm{Ph}$, Klimpfinger $\mathrm{M}$, Denk $\mathrm{H}$. Extended radical surgery against gastric cancer: low complication and high survival rates. Jpn I Clin Oncol 1992;22:102-106

5. Everett SM, Axon ATR. Early gastric cancer in Europe. Gut 1997;41:142-150

6. Hanazaki $\mathrm{K}$, Sodeyama $H$, Wakabayashi $M$, Miyazawa $M$, Yokoyama $S$, Sode $Y$, Kawamura N, Miyazaki T, Ohtsuka M. Surgical treatment of gastric cancer detected by mass screening. Hepato Gastroenterology 1997;44:1126 1132

7. Hisamichi Shigeru. Screening for Gastric Cancer. World J Surg 1989;13:31-37

8. Takeda J, Koufuji K, Kodama I, Tsuji Y, Maruiwa M, Kawabata S, Soematsu T, Kagegawa $T$. Retrospective studies of synchronous double early gastric cancer. Kurume Med J 1993:40:53-57

9. Maruyama $\mathrm{K}$. The most important prognostic factor for the gastric cancer patient. Scand J Gastroenterol 1987;22:63-68

10. Moureaux J, Bougaran J. Early gastric cancer. A 25-year surgical experience. Ann Surg 1993;217:347-355

11. Pinto E, Roviello F, de Stefano A, Vindigni C. Early gasiric cancer: report on 142 patients observed over 13 years. Jpn I Clin Oncol 1994;24:12-19

12. Spataro V, Genoni M, Maurer C, Müller W. Stomach cancer: 10 years experiences with surgical treatment and possibilities for improving the prognosis. Helv Chir Acta 1993;59:589-595

13. Tida F, Koike $S$, Koide N. Extended total gastrectomy for carcinoma of the cardia. Hepato-gastroenterology 1993;40:103-106

14. Roder JD, Böttcher K, Siewert JR, Busch R, Hermanek P, Meyer HJ. Prognostic factors in gastric carcinoma. Result of the German Gastric Carcinoma Study. Cancer 1993;72:2089-2097

15. Gall FP, Altendorf A, Hermanek P, Gentsch HH. Chirurgische Therapie des Magenkrebses-Stagnation oder Fortschritte? Ergebnisse bei 2665 MagenkrebsPatienten. Fortschr Med 1982;100:1876-1882

16. Koga S, Kishimoto H, Tanaka K, Miyano Y, Kawaguchi H, Takeda R, Nishidoi H, Kumura $O$. Results of total gastrectomy for gastric cancer. Am J Surg $1980 ; 140: 636-638$

17. Takeda J, Koufuji K, Kodama I Tsuji Y, Yokoyama T, Kawabata S, Suematsu T, Kakegawa $T$. Total gastrectomy for gastric cancer: 12-year data and review of the effect of performing lympladenectomy. Kurume Med J 1994:41:15-21 
18. Moriguchi S, Hayashi $Y$, Nose $Y$ Maehara $Y$, Korenaga D, Sugimachi $K$. A comparison of the logistic regression and the Cox proportional hazard models in retrospective studies on the prognosis of patients with gastric cancer. I Surg Oncol $1993 \cdot 52: 9-13$

19. Schiessel R Wenzl E, Pratschner T. Results of the surgical therapy of stomach cancer. Wien Klin Wochenschr 1987;99:406-410

20. Nakajima $T$, Nishi M. Kajitani T. Improvement in treatment results of gastric cancer with surgery and chemotherapy. Experience of 9700 cases in the Cancer Institute Hospital, Tokyo. Semin Surg Oncol 1991;7:365-372

21. Meyer HJ, Jähne J, Wilke H, Pichlmayr R. Surgical Treatment of Gastric Cancer: Retrospective Survey of 1,704 Operated Cases With Special Reference to Total Gastrectomy as the Operation of Choice. Semin Surg Oncol 1991;7:356-364

22. Maruyama K Okabayashi $K$, Kinoshita $T$. Progress in gastric cancer surgery in Japan and its limits of radicality. World J Surg 1987;11:418-425

23. Neugut Al, Hayek M, Howe G. Epidemiology of Gastric Cancer. Semin OncolGastric Cancer. 1996;23930:281-291

24. Diehl JT, Hermann RE, Cooperman AM, Hoerr SO. Gastric Carcinoma-A TenYear Review. Ann Surg 1983;9-12

25. Fortner JG, Lauwers GY, Thaler HT, Concepcion R, Friedlander-Klar $H$, Kher U, Maclean BJ. Nativity, complications, and pathology are determinants of surgical results for gastric cancer. Cancer 1994;73:8-14

26. Korenaga D, Moriguchi $S$, Orita $H$, Kakeji $Y$, Haraguchi M, Maehara $Y$, Sugimachi $K$. Trends in survival rates in Japanese patients with advanced carcinoma of the stomach. Surg Gynecol Obstet 1992;174:387-393

27. Farris JM, Ransom HK, Coller FA. Total Gastrectomy: Effects upon Nutrition and Hematopoisis. Surgery 1943;13:823-833

28. van der Kleij FGH, Vecht J, Lamers CBHW, Masclee AAM. Diagnostic value of dumping provocation in patients after gastric surgery. Scand J Gastroenterol $1996 ; 31: 1162-1166$

29. Lantone $\mathrm{G}$, Lorusso D, Pezzolla F, Lacatena M, Guerra V, Giorgio $\mathbb{1}$. Reconstruction of the digestive tract after total gastrectomy. A comparison of Roux anastomosis with Nakayama's beta anastomosis. Minerva Chir 1991;46:885-888

30. Parrilla P, Liron R, Martinez de Haro LF, Ortiz A, Molina J, De Andrés B. Gastric surgery does not increase the risk of developing Barrett's esophagus. AJG 1997:92:960-963

31. Debas HT, Orloff SL. Surgery for Peptic Ulcer Disease and Postgastrectomy Syndromes. In: Yamada T, Alpers DH, Owyang C, Powell D, Silverstein F eds. Textbook of Gastroenterology. Philadelphia: J.B. Lippincott, 1995;1:1523-1543

32. Tanaka $T$, Fujwara $Y$, Nakagawa $K$, Kusunoki $M$, Utunomiya J. Reflux Esophagitis after Total Gastrectomy with Jejunal Pouch Reconstruction: Comparison of Long and Short Pouches. Am J Gastroenterol 1997:92:821-824

33. Behrns KE, Sarr MG. Diagnos is and management of gastric emptying disorders. Adv Surg 1994:27:233-255 
34. Wechsler, JG. Emälltrungsverhalten und Diăt nach Gastrektomie. In Armbrecht U, Stockbrügger RW eds. Der gastrektomierte Patient. Karger 1992:79487

35. Miholic J, Meyer HJ, Balks J, Kotaerke J. Einflul der Rekonstruktionsmethode auf den Ernährungszustand nach Gastrektomie. Vergleich von Roux-en-YOsophagojejunostomie und Jejunuminterposition. Chirurg 1991;62:300-305

36. Pellegrin CA, Deveney CW, Patti MG, Lewin M, Way LW. Intestinal transit of food after total gastrectomy and Roux $-Y$ esophagojejunostomy. Am I Surg 1986; $151: 117-125$

37. Stockbrügger RW, Armbrecht U, Rode JW, Teall AJ, Oberholzer VG, Croker JR, Cotton PB. The Bacterial Overgrowth Syndrome is Uncommon in Pernicious Anaemia: Results of a Follow-up Study. Microbial Ecology in Health and Disease $1990 ; 3: 209-215$

38. Husebye E. Gastrointestinal motility disorders and bacterial overgrowth. I Int Med $1995 ; 237: 419-427$

39. Drasar BS, Shiner M. Studies on the intestinal flora. Part II Bacterial flora of the small intestine in patients with gastrointestinal disorders. Gut 1969;10:812-819

40. Kumar A, Forsmark CE, Toskes PP. Smalt bowel bacterial overgrowth: The changing face of an olld disease. Gastroenterology 1995:110:A340

41. Affleck JW, Aitken RCB, Hunter JAA, McGuire RJ, Roy CW. Rehabilitation

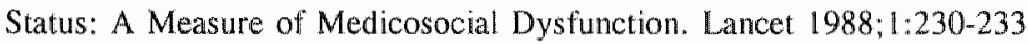

42. Wagner MK, Armstrong D, Laughlin JE. Cognitive determinants of quality of life after onset of cancer. Psychol Rep 1995;77:147-154

43. Faller $H$, Lang $H$, Schilling S. Causal "cancer personality" attribution- an expression of maladaptive coping with illness? Z Klin Psychol Psychopathol Psychther 1996;44:104-116

44. Grassi L, Rosti G. Psychosocial morbidity and adjustment to illmess among longterm cancer survivors. A six-year follow-up study. Psychosomatics 1996;37:523532

45. Dunkel-Schetter D, Feinstein LG. Taylor SE, Falke RL. Patterns of coping with cancer. Health Psychol 1992:11:79;87

46. Classen C, Koopman C, Angell K, Spiegel D. Coping styles associated with psychological adjustment to advanced breast cancer. Health Psychology $1996 ; 15: 434-437$

47. Holland JC, Korzun AH, Tross S, Silberfarb P, Perry M, Comis R, Oster M. Comparative psychological disturbance in patients with pancreatic and gastric cancer. Am J Psy 1986;143:982-986

48. Muthny FA. Bechtel M, Spaete M. Lay etiologic theories and coping with illness in severe physical diseases. An empirical comparative study of femalc myodardial infarct, cancer, dialysis and multiple sclerosis patients. Psychother Psyshosom Med Psychol 1992;42:41-53

49. Theissen HH. Coping with illness in the postoperative phase following gastrectomy. Z Gastroenterol 1996;34:29-31

50. Feifel H, Strack S, Nagy VT. Degree of life-threat and differential use of coping modes. J Psychosom Res 1987;31:91-99 


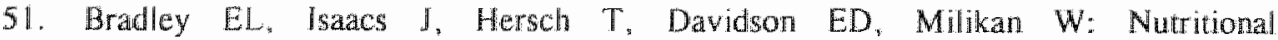
consequences of total gastrectomy. Ann Surg 1975;182:415-429

52. Harju $E$. Dietary habits and eating related symptoms in out-patients following total gastrectomy and Roux-en-Y reconstruction for carcinoma of the stomach. Anticancer Res 1985;5:277-279

53. Lankisch PG. Enzyme Treatment of Exocrine Pancreatic Insufficiency in Chronic Pancreatitis. Digestion 1993;54:21-29

54. Friess H, Bohm J, Müller MW, Glasbrenner B, Riepl RL, Malfertheiner P, Büchler MW. Maldigestion after total gastrectomy is associated with pancreatic insufficiency. Am $\mathbb{G a s t r o e n t e r o l ~ 1 9 9 6 ; 9 1 : 3 4 1 - 3 4 7 ~}$

55. Buchler $M$, Malfertheiner P, Glasbrenner $B$, Beger HG. Rat exocrine pancreas function following total gastrectomy. Int J Pancreatol 1986;1:389-398

56. Giasbrenner B, Malfertheiner P, Büchler $M$, Brandle F, Friess $H$, Ditschuneit $H$. Long-term effect of growih promoting conditions on the exocrine pancreas of rats. Int J Pancreatol 1989;5:55-67

57. Armbrecht U, Brägelmann R, Baumgart I, Stockbrugger RW. Fecal Chymotrypsin Output in Relation To Fecal Fat after Partial and Total Gastrectomy. Gastroenterology April 1994;106:A219

58. Layer P, Schlesinger T, Gröger G, Goebell H. Modulation of Human Periodic Interdigestive Gastrointestinal Motor and Pancreatic Function by the lleum. Pancreas 1993;8:426-432

59. Fuchs $K H$, Thiede A, Engemann R, Deltz E, Stremme O, Hamelmann $H$. Reconstruction of the food passage after total gastrectomy: randomized trial. World J Surg 1995; 19:698-705

60. Tabaqchali S. The Pathophysiological Rolle of Small Intestinal Bacterial Flora. Scand J Gastroenterol 1970;6:139-163

61. Kim YS, Spritz M. Blum M, Terz J, Sherlock P. The role of altered bile acid metabolism in the steatorhea of experimental blind loop. J Clin Invest 1966; $45: 956 \cdot 962$

62. Shimoda SS, O'Brien TK, Saunders DR. Fat absorption after infusing bile salts into the human small intestine. Gastroenterology 1974;67:7-18

63. Wanitsche R, Ammon HV. Effects of dihydroxy bile acids and hydroxy fatty acids on the absorption of oleic acid in the human jejunum. J Clin Invest 1978;61:178186

64. Zieren HU, Zippel K, Zieren J, Müller JM. Quality of Life after Surgical Treatment of Gastric Carcinoma. Eur J Surg 1998;164:119-125 


\section{Chapter XI}

\section{Summary and Concluding Remarks}




\section{Summary and Concluding Remarks}

The present thesis supplies data on some aspects of patients after a curative totall gastrectomy for gastric malignancy.

In Chapter I a critical review regarding post-gastrectomy problems is given. Due to differences in definition and method of assessment the frequency and the reported clinical relevance of abdominal and systemic symptoms after total gastrectomy vary widely. Malnutrition, as defined by weight loss and micronutrient deficiencies, can be caused by either anorexia, absolute pancreatic insufficiency or pancreatico-cibal asynchrony, rapid upper intestinal transit, upper intestinal bacterial overgrowth, or any combination of these variables. The possible influence of different surgical reconstructions after gastrectomy with regard to functional outcome is discussed. It is outlined that any study on the pathophysiology of postgastrectomy malnutrition needs to control for all these variabels.

Quality of life after total gastrectomy has been examined in numerous trials comparing different reconstruction procedures, but still little is known about interrelations between physical and biochemical variables and post-operative physical, mental, and social performance. An introduction to the concept of coping strategies is provided.

In Chapter II the patients examined, the clinical setting of the examination, and the methods used in the studies performed are presented.

In Chapter III a descriptive analysis of our patient group is given and a preliminary analysis of possible pathophysiological mechanisms of nutrient malassimilation was done.

Mean body mass index according to Quetelet (BMI) was $26.61 \mathrm{~kg} / \mathrm{m}^{2}$ (SEM 0.31) pre-operatively and $22.06 \mathrm{~kg} / \mathrm{m}^{2}$ (SEM 0.23 ) on admission to the rehabilitative clinics. $96 \%$ of the patients had lost weight pre-operatively, and $67 \%$ had lost weight since the operation. Only $13 \%$ were underweight at the time of operation, whereas $25 \%$ of the patients were underweight on admission to the rehabilitative clinics.

Under standardised dietary conditions abdominal symptoms were found in $86 \%$ of the patients, but they were not severe. In a univariate subgroup analysis of patients with low calorie intake $(<30$ kilocalories per kilogram body weight per day) and of patients with higher calorie intake ( $\geq 30$ kilocalories per kilogram body weight per day) it was found that the latter reported significantly less early satiety and vomiting, whilst meteorism was more frequent.

Strikingly, 138 of our 174 patients $(79 \%)$ did not have iron supplementation on admission. In these patients moderate anaemia was found in $48.6 \%$ and sideropenia in $26.7 \%$. Ferritin concentrations decreased logarithmically with time past. operation. Vitamin $B_{12}$ supplementation, on the other hand, had been given to 126 of 173 patients $(72 \%)$. Only $63 \%$ of the patients reported that they had be given 
dietary advice after the operation. The energy intake of most patients under inpatient conditions is sufficient (median $37.8 \mathrm{kcal} / \mathrm{kg}$ body weight and day) with $25 \%$ of them consuming more than $43.1 \mathrm{kcal} / \mathrm{kg}$ body weight and day. Pailents after total gastrectomy had a normal defaecation frequency with normal to soft stools. They produced stools of relatively low volume (median 219, IQR (139322) $\mathrm{g} / \mathrm{d})$ with a rather high fat output (median $12.9,1 \mathrm{IR}(6.2-21.6) \mathrm{g} / \mathrm{d})$ due to a median fat malabsorption of $11.6 \%$ (IQR 5.1-19.6). The range of the fat malabsorption was five to $80 \%$ pointing to clinically relevant individual differences. Compared to patients with moderate steatorrhoea (faecal fat 7-14 g/d), patients with severe steatorrhoea (faecal fat $>14 \mathrm{~g} / \mathrm{d}$ ) had a significantly higher incidence of shortened oro-coecall transit $(<75$ minutes) and were admitted earlier after operation.

Alkaline reflux oesophagitis was present in $26 \%$ of the patients examined. Small bowel bacterial overgrowth as assessed with an $\mathrm{H}_{2}$-breath test was found in $37 \%$ and oro-coecal transit faster than 75 minutes was diagnosed in $21.7 \%$ of the patients.

In Chapter IV three different functional types of gastric reconstruction after total gastrectomy - duodenal bypass with or without pouch construction, and jejunal interposition, - are compared as to their relevance for functional post-operative performance.

Not one of the numerous parameters examined revealed any statistically significant difference between these different surgical procedures. In conclusion, in our study neither subjective nor objective data support preference for any single mode of reconstruction after total gastrectomy for gastric cancer.

In Chapter V a double-blind, randomised, parallel, placebo-controlled trial with a high dosage pancreatic enzyme supplementation in 52 patients with a faecal fat output $\geq 14 \mathrm{~g} / \mathrm{day}$, operated on for malignant gastric disease 198 (median; interquartile range 47-608) days previously, and free from recurrence and/or metastasis is reported.

After treatment with lipase 72.000 , amylase 54.000 , and protease 4.800 FIP per every major meal and half of it per every smaller meal, patients on enzyme therapy felt better overall, but no improvement of a specific symptom could be identified. Enzyme treatment did not result in a significant difference between the placebo and the enzyme treated group regarding fat malassimilation.

The effect of high dose pancreatic enzymes supplementation on symptoms and steatorrhoea after totall gastrectomy is marginal and does not justify its routine use.

In Chapter VI the influence of a rapid oro-coecal transit time (below 75 minutes) on symptoms, malnutrition, and post-operative performance is discussed.

Bloating was significantly more frequent in patients with a rapid oro-coecal transit. The median faecal chymotrypsin concentration was significantly lower in patients with oro-coecal transit time below 75 minutes compared to the remainder (2.7 (IQR 
2.1 to 4.6 ) vs. 4.9 (IQR 2.9 to 7.2$)$ U/g; $p<0.05$ ). Furthermore, median faecal chymotrypsin output during 72 hours tended to be lower in the patients with an oro-coecal transit time below 75 minutes. Patients with rapid oro-coecal transit had a $50 \%$ higher median daily faecal fat output $(p<0.02)$ and a $47 \%$ higher fat malassimilation $(p<0.05)$ compared to patients with normal transit. The number of patients with a daily faecal fat output exceeding 14 grams was $24 / 62 .(39 \%)$ in the group with normal oro-coecal transit time versus $22 / 34$ (65\%) in those patients with rapid oro-coecal transit $(\mathrm{p}=0.02)$.

In patients with relevant steatorrhoea after total gastrectomy measures prolonging small-intestinal transit should be employed.

In Chapter VII patients with and patients without small bowel bacterial overgrowth after total gastrectomy were compared.

Mean time since operation was significantly shorter in patients with small bowel bacterial overgrowth than in patients without small bowel bacterial overgrowth ( $(370$, confidence interval $=\mathrm{Cl} 96-645$ vs. $687, \mathrm{Cl} 397-976)$ days; $\mathrm{p}<0.01)$. Controlling for this difference, there were no other significant differences in symptoms and signs between the subgroups except for the medico-social functioning measured with the Edinburgh Rehabilitation Status Scalle (ERSS). The mean ERSS showed significantly better medico-social functioning in patients without small bowel bacterial overgrowth than in the remaincler $(3.7 \mathrm{CI}(2.2-5.2)$ vs. $5.1 \mathrm{CI}(3.0-7.0) ; \mathrm{p}<0.05)$.

The clinical complaints of patients after gastrectomy do not seem to be due to bacterial overgrowth and the post-operative achlorhydric state does not necessarily cause a bacterial overgrowth syndrome.

In Chapter VIII the objective was to describe post-operative medico-social performance after curative total gastrectomy and to identify the factors determining it. A linear regression analysis of a great number of social, biochemical and physical parameters was performed.

The median ERSS-score was 4 (IQR 2 to 6 ) on a scale from 0 (besl) to 28 (worsi). The patients of the centre serving mainly blue collar worker had higher scores than the two other centres. Time past operation and albumin concentrations were negatively correlated with the Edinburgh Rehabilitation Status Scale (ERSS), and dyspepsia, dysphagia, and reflux were positively correlated to the ERSS-score. Increasing degrees of pathological findings at upper intestinal endoscopy were positively correlated with the ERSS-scores in a univariate analysis.

In Chapter IX coping strategies of patients after total gastrectomy were examined in 50 patients who accepted the invitation of a psychological interview in which a standardised manual was used. The pattern compliance strategy and trust in doctors scored significantly higher than all the other fields $(\mathrm{p}<0.0001)$. The patterns selfsupport and relativation by comparison had significantly higher ratings than all the other fields $(\mathrm{p}=0.0001)$ with the exception of the field compliance strategy and 
trust in doctors. Problem analysis and problem solving and hedonism scored significantly higher $(\mathrm{p}=0.0003)$ than cognitive denial and dissimulation or the remaining seven fields not mentioned. The fields compliance strategy and trust in doctors, hedonism, regressive tendency, relativation by comparison, and selfsupport had at least ten patients $(20 \%)$ above the mean score of the disease-conirol group, whereas only the field emotional control and social isolation had ten patients below the mean of the disease-control group. There was a positive correlation of the field hedonism with time past operation $\left(\mathrm{r}^{2}=0.5, \mathrm{p}<0.0001\right)$.

Active and problem-oriented coping patterns were predominant in a group of cancer-free patients after total gastrectomy for gastric malignancy. If these coping patterns are recognised by the managing physician(s), post-operative rehabilitation can probably be further improved.

In Chapter $\mathbf{X}$ the combined results of these studies are integrated to discuss which factors might be relevant for nutrient malassimilation after total gastrectomy, and what determines post-operative medico-social functioning.

Symptom-induced low calorie intake and pancreatico-cibal asynchrony due to rapid small-intestinal transit, acting alone or in concert, seem to be the major reasons for nutrient malassimilation in patients after total gastrectomy.

The social and working situation of the patient, time after operation, symptoms of dyspepsia, dysphagia, and reflux into the oesophagus were independent determinants of medico-social performance after total gastrectomy.

Future studies might focus on measures to prolong intestinal transit in patients with rapid small intestinal transit in order to decrease post-gastrectomy steatorrhoea. Another - possible more important - challenge is to further elucidate the nature of post-gastrectomy dyspepsia in order to establish adequate therapeutic measures. 


\section{Chapter XII}

Samenvatting 


\section{Samenvatting}

In dit proefschrift worden enkele aspecten van patiënten na een curatieve totale maagresectie besproken.

In Hoofdstuk wordt een kritisch overzicht over post-gastrectomie problemen gegeven. Omdat definities en methoden vaak verschillen, varieren de frequentie en de gerapporteerde klinische relevantie van abdominale en systemische symptomen na totale gastrectomie nogal sterk. Malnutritie, gedefinieerd als gewichtsverlies en deficiëntie van micronutriënten, kan veroorzaakt worden door anorexie, absolute pancreasinsufficiëntie of pancreatico-cibale asynchronie, versnelde dunne darm passage, bacteriële overgroei van de dunne darm, of iedere combinatie van deze variabelen. De mogelijke invloed van verschillende chirurgische reconstructies na gastrectomie op het functioneel resultaat wordt besproken. Beschreven wordt, dat iedere studie over de pathophysiologie van post-gastrectomie malnutritie voor al deze variabelen gecontroleerd moet zijn.

De samenhang van kwaliteit van leven na totale gastrectomie en verschillende reconstructie procedures is in een aantal studies onderzocht. In tegenstelling hiermee is over de relaties van lichamelijke en biochemische variabelen en het post-operatieve lichamelijke, mentale, en sociale functioneren minder bekend. Een inleiding over het concept "ziekteverwerking" wordt gegeven.

In Hoofdstuk II worden de patiënten, de klinische omgeving, en de gebruikte methoden van de volgende studies beschreven.

In Hoofdstuk III wordt een descriptieve analyse van onze patiënten groep verricht en een voorlopige analyse van mogelijke pathophysiologische mechanismen van nuirient malassimilatie gegeven.

De gemiddelde body mass index volgens Quetelet (BMI) was preoperatief $26.61 \mathrm{~kg} / \mathrm{m}^{2}$ (SEM 0.31) en bij opname in de revalidatie kliniek $22.06 \mathrm{~kg} / \mathrm{m}^{2}$ (SEM 0.23 ). Van de patiënten had $96 \%$ voor de operatie gewicht verloren, en $67 \%$ hadden na de operatie gewicht verloren. $25 \%$ van de patiënten was bij opname in de revalidatie klinieken onder hun streefgewicht, terwijl ten tijde van de operatie dit slechts $13 \%$ was.

Onder gestandaardiseerde dieet-omstandigheden werden abdominale symptomen bij $86 \%$ van de patiènten gevonden, maar deze waren niet emstig. Bij een univariate analyse van paẗënten met lage calorie opname $(<30$ kilocalorieen per kilogram lichamsgewicht per dag) en patiënten met hogere calorie opname ( $\geq 30$ kilocalorieen per kilogram licharnsgewicht per dag) hadden de eersten significant vaker een vroege verzadiging en last van braken, terwijl een opgeblazen gevoel minder vaak voorkwam.

Verrassend was, dat 138 van 174 patiënten ( $79 \%$ ) bij opname geen ijzer suppletie hadden. $48.6 \%$ van deze patiënten had een matige anemie en $26.7 \%$ had een sideropenie. Ferritine concentraties nemen logaritmisch in de loop van de tijd af. 
Bij 126 van 173 patiënten (72\%) was het vitamine $B_{12}$ gesupplementeerd. Slechts $63 \%$ van de patiënten zei, dat ze dieet-advies hadden gekregen na de operatie. De energie opname van de meeste patiënten tijdens de opname was voldoende (mediaan $37.8 \mathrm{kcal} / \mathrm{kg}$ lichaamsgewicht per dag) en $25 \%$ van hen consumeerde meer dan $43.1 \mathrm{kcal} / \mathrm{kg}$ lichaamsgewicht per dag. De patiënten na totale gastrectomie hadden een normale ontlastingsfrequentie met normaal gevormde tot breiige faeces. De ontlastingsvolumina waren relatief laag (mediaan 219, IQR (139$322) \mathrm{g} / \mathrm{d}$ ) met een vrij hoog vet verlies (mediaan 12.9 , IQR $(6.2-21.6) \mathrm{g} / \mathrm{d}$ ) door een gemiddelde vet malabsorptie van 11.6 percent (IQR 5.1-19.6). Het bereik van de vet malabsorptie was vijf tot $80 \%$, wat op klinisch belangrijke individuele verschillen wijst. Patiënten met een ernstige steatorrhoea (faecaal vet $\geq 14 \mathrm{~g} / \mathrm{d}$ ) hadden significant vaker een oro-coecale transit tijd korter dan 75 minuten en werden vroeger na operatie verwezen dan patiënten met slechts een matige steatorrhoea (faecaal vet $<14 \mathrm{~g} / \mathrm{d}$ ).

Alkalische reflux esophagitis was bij $26 \%$ van de onderzochte patiënten te vinden. Bacteriële overgroei van de dunne darm, onderzocht met de $\mathrm{H}_{2}$-adem test, werd gediagnostiseerd bij 37\%; een oro-coecale transit tijd onder de 75 minuten bij $21.7 \%$ van de patiënten.

In Hoofdstuk IV werden drie functioneel verschillende typen van gastrische reconstructie na totale gastrectomie - het uitsluiten van het duodenum met of zonder pouch, en jejunale interpositie - ten opzichte van hun relevantie voor de post-operatieve functie vergeleken.

Geen enkele van de talrijke onderzochte parameters toonde enig statistisch significant verschil tussen deze operatieve procedures. Samenvattend kan gezegd worden, dat noch subjectieve noch objectieve gegevens een voorkeur voor één bepaalde soort reconstructie na totale gastrectomie bij maagcarcinoom ondersteunen.

In Hoofdstuk $\mathbf{V}$ wordt een dubbel-blinde, gerandomiseerde, parallelle, placebogecontroleerde studie met een hoge dosering van pancreas enzym suppletie bij 52 patiënten met een faecaal vet verlies $\geq 14 \mathrm{~g} /$ dag besproken. De patiënten waren 198 dagen (mediaan, interquartile range 47-608) post-operatief en vrij van recedief en/of metastasen.

$\mathrm{Na}$ de behandeling met lipase 72.000 , amylase 54,000 , en protease 4.800 FIP bij iedere hoofdmaaltijd en nog een keer de helft hiervan bij iedere nevenmaaltijd gaven patiënten met enzym therapie aan, zich beter te voelen. Een verbetering van een specifiek symptoom kon niet worden aangetoond. Enzym suppletie had geen significante verandering voor de vet absorptie tussen de groep met placebo en de groep met enzymen ten gevolge.

Het effect van hoog gedoseerde pancreatische enzym suppletie op symptomen en steatorrhoea na totale gastrectomic is marginaal en een routinematig voorschrijven niet geindiceerd. 


\section{Chapter XIII}

\section{Zusammenfassung und}

Kommentar 


\section{Zusammenfassung und Kommentar}

Die vorliegenden Studien enthalten Daten zur Situation nach kurativer totaler Gastrektomie wegen maligner Magentumoren.

In Kapitel I wird ein kritischer Überblick über die Probleme nach totaler Gastrektomie gegeben. Durch Unterschiede in Definition und Erhebungsmethodik unterscheiden sich die angegebene Frequenz und die berichtete klinische Relevanz von abdominalen und systemischen Beschwerden nach totaler Gastrektomie erheblich. Mangelernährung - definiert durch Gewichtsverlust und/oder Mangel an Vitaminen und Spurenelementen - kann durch Anorexie, absolute Pankreasinsuffizienz oder pankreatico-cibale Asynchronie, beschleunigte oro-zökale Passage, bakterielle Überwucherung des Dünndarms oder eine Kombination dieser Faktoren verursacht sein. Des weiteren wird diskutiert, in wieweit die Art der chirurgischen Magenrekonstruktion einen. Einfluß auf die postoperative Funktion hat. Es wird dargelegt, daß jede Studie zur Pathophysiologie der postoperativen Mangelernährung alle obengenannten Variablen gleichzeitig erfassen muß.

Der Einfluß verschiedener Rekonstruktionsverfahren auf die Lebensqualität nach totaler Gastrektomie ist in vielen Studien untersucht worden. Die Zusammenhänge zwischen somatischen und biochemischen Faktoren und der postoperativen somatischen, mentalen und soziallen Leistungsfähigkeit der Patienten sind jedoch weitgehend unklar. Es wird eine Einführung in das Konzept der Krankheitsverarbeitung gegeben.

In Kapitel II werden die untersuchten Patienten der Studien, die klinische Umgebung, und die angewandten Methoden erläutert.

Kaptitel III beinhaltet eine deskriptive Analyse unserer Patientengruppe sowie eine vorläufige Analyse möglicher pathophysiologischer Mechanismen der Nährstoffmalassimilation.

Der durchschnituliche Body Mass Index nach Quetelet (BMI) vor der Operation war 26.61 (SEM 0.31). Bei Aufnahme in den Rehabilitationskliniken betrug dieser Wert 22.06 (SEM 0.23). 96\% der Patienten hatten vor der Operation Gewicht verloren, und bei $67 \%$ setzte sich der Gewichtsverlust auch nach der Operation fort. Bei Aufnahme in den Rehabilitationskliniken waren $25 \%$ der Patienten untergewichtig, während dies zum Zeitpunkt der Operation bei nur 13\% der Fall war.

Unter standardisierten diätetischen Bedingungen wurden von $86 \%$ der Patienten leiclute abdominale Beschwerden angegeben. Eine univariate Analyse von Patienten mit niedriger Kalorienaufnahme ( $<30$ Kilokalorien pro Kilogramm Körpergewicht und Tag) und Patienten mit höherer Kalorienaufnahme ( $>30$ Kilokalorien pro Kilogramm Körpergewicht und Tag) zeigte, daß letztere signifikant seltener Probleme mit frühem Sättigungsgefühl und Erbrechen hatten, während Blähungen häufiger waren.

Überraschenderweise hatten 138 unserer 174 Patienten $(79 \%)$ bei Aufnahme keine 
Eisensubstitution. Bei diesen Patienten wurde in $48.6 \%$ der Fälle eine geringe Anämie und in $26.7 \%$ der Fälle eine Sideropenie gefunden. Die Ferritinwerte nehmen nach Operation im Sinne einer logarithmischen Funktion ab. Substitution mit Vitamin $B_{12}$ hatten 126 won 173 Patienten $(72 \%)$ erhalten. Nur $63 \%$ der Patienten gaben an, nach der Operation Diätratschläge bekommen zu haben. Die Energieaufnahme der meisten Patienten unter Klinikbedingungen ist ausreichend (Median 37.8 Kilokalorien pro Kilogranm Körpergewicht und Tag). $25 \%$ der Patienten konsumierten mehr als 43.1 Kilokalorien pro Kilogramm Körpergewicht und Tag. Die Patienten nach totaler Gastrektomie hatten eine normale Stuhlfrequenz mit normaler oder weicher Konsistenz. Die Stühle hatten eine relativ geringes Volumen (Median 219, IQR (139-322) g/d) mit einem hohen Fettanteil (Median 12.9, IQR $(6.2-21.6) \mathrm{g} / \mathrm{d})$. Dies wird durch eine Fetmalabsorption verursacht, die im Mittel 11.6\% (IQR 5.1-19.6) beträgt. Die Spanne der Fettmalabsorption war fünf bis $80 \%$. Dies weist auf klinisch relevante individuelle Unterschiede hin. Patienten mit mäßiger Steatorrhoe (Stuhlfett $<14 \mathrm{~g} / \mathrm{T}$ ) hatten im Gegensatz zu Patienten mit ernster Steatorrhoe (Stuhlfett $\geq 14 \mathrm{~g} / \mathrm{T}$ ) signifikant häufiger eine oro-zökale Passagezeit unter 75 Minuten und waren früher nach Operation eingewiesen.

Eine alkalische Refluxösophagitis lag bei $26 \%$ der untersuchten Patienten vor. Eine bakterielle Überwucherung des Dünndarms oder eine oro-zökale Passagezeit unter 75 Minuten wurden mit dem $\mathrm{H}_{2}$-Atemtest bei $37 \%$ respektive $21.7 \%$ diagnostiziert.

In Kapitel IV werden drei funktionell verschiedene Rekonstruktionstypen nach totaler Magenresektion, nämlich die Ausschaltung des Duodenums jeweils mit oder ohne Pouchkonstruktion und die jejunale Interposition, bezüglich ihrer postoperativen funktionellen Ergebnisse verglichen.

In keinem einzigen der zahlreichen untersuchten Faktoren wurden statistisch signifikante Unterschiede zwischen den Operationsmethoden festgestellt. An Hand unserer Daten kann keiner der untersuchten Rekonstruktionsverfahren nach totaler Gastrektomie der Vorzug gegeben werden.

In Kapitel $\mathbf{V}$ werden die Ergebnisse einer doppelblinden, randomisierten, parallelen, placebo-kontrollierten Interventionsstudie mit hochdosierten Pankreasenzymen bei 52 Patienten mit einer Stuhlfettausscheidung won $\geq 14 \mathrm{~g} / \mathrm{T}$ berichtet. Die Patienten waren 198 Tage (Mittel, IQR 47-608) zuvor wegen Magenmalignität operiert worden und zum Zeitpunkt der Untersuchung tumor- und metastasenfrei.

Nach Behandlung mit 72.000 Einheiten Lipase, 54.000 Einheiten Amylase, und 4.800 Einheiten Proteasen (FIP) zu jeder Haupmahlzeit und der Hälfte dieser Dosierung zu jeder Nebenmahlzeit gaben die Patienten mit Enzymtherapie zwar an, sich im Ganzen besser zu fühlen; Verbesserung eines spezifischen Symptomes konnte jedoch nicht identifiziert werden. Die Fettmalabsorption wurde durch die Intervention nicht signifikant beeinflußt. 
Der Einfluß von hoch dosierter Substitution mit Pankreasenzymen auf Symptome und Steatorrhoe nach totaler Gastrektomie ist marginal und eine routinemäßige Verschreibung ist nicht gerechtfertigt.

Der Einfluß einer beschleunigten oro-zökalen Passage (schneller als 75 Minuten) auf Symptome, Fehlernährung und postoperative Leistungsfähigkeit wird in Kapitel VI diskutiert.

Patienten mit beschleunigter Passage hatten signifikant häufiger Blähungen. Die mittlere Stuhlkonzentration des Chymotrypsins war bei Patienten mit einer orozökalen Passage unter 75 Minuten signifikant niedriger als bei den übrigen Patienten (2.7 (IQR 2.1 to 4.6 ) ws. 4.9 (IQR 2.9 to 7.2 ) U/g; $p<0.05$ ). Die mittlere fákale Chymotrypsinausscheidung über 72 Stunden war bei Patienten mit beschleunigter oro-zökalen Passage zwar niedriger, aber der Unterschied war nicht signifikant. Patienten mit beschleunigter oro-zökaler Passage hatten im Vergleich mit den übrigen Patienten eine $50 \%$ höhere tägliche Stuhlfettausscheidung $(p<0.02)$ und eine $47 \%$ höhere Fettmalabsorption $(p<0.05)$. Die Zahl der Patienten mit einer täglichen fäkalen Fettausscheidung von mehr als $14 \mathrm{~g} / \mathrm{T}$ betrug $24 / 62(39 \%)$ bei den Patienten mit normaler Passagezeit, während es bei den Patienten mit beschleunigter oro-zökalen Passage 22/34 (65\%) waren $(p=0.02)$.

Bei Patienten mit relevanter Steatorrhoe nach totaler Gastrektomie sollten Maßnahmen zur Verlängerung der oro-zökalen Passagezeit untersucht werden.

In Kapitel VII wurden Patienten nach totaler Gastrektomie mit und ohne bakterieller Überwucherung des Dünndarms verglichen.

Die Zeit seit der Operation war signifikant kürzer bei Patienten mit bakterieller Überwucherung des Dünndarms ( $(370$, Konfidenzinterval $=\mathrm{CI} 96-645$ vs. 687, Cl 397-976) Tage; $p<0.01)$. Unter statistischer Berücksichtigung dieses Unterschieds gab es keine weiteren Unterschiede zwischen den Gruppen, mit Ausnahme des medizinisch-sozialen Funktionierens, das mit der Edinburgh Rehabilitation Status Scale (ERSS) bestimmt wurde. Der durchschnittliche ERSS-Wert zeigte bei Patienten ohne bakterielle Überwucherung im Vergleich zu den anderen Patienten ein besseres medizinisch-soziales Funktionieren an $(3.7 \mathrm{Cl}(2.2-5.2)$ vs. $5.1 \mathrm{Cl}$ $(3.0-7.0) ; \mathrm{p}<0.05)$.

Die Beschwerden der Patienten mach totaler Gastrektomie scheinen nicht durch eine bakterielle Überwucherung venursacht zu sein. Der postoperative achlorhydrische Zustand führt nicht zwingend zu einem bakteriellen Überwucherungs Syndrom.

Ziel der Überlegungen in Kapitel VIII war es, das postoperative medizinischsoziale Funktionieren nach kurativer totaler Gastrektomie zu beschreiben und Faktoren zu identifizieren, die es bestimmen. Ein lineares Regressionsmodel mit einer großen Anzahl von sozialen, biochemischen und somatischen Faktoren wurde analysiert.

Der mittlere ERSS-Wert betrug 4 (IQR 2 bis 6) auf einer Skala von 0 (bester Wert) bis 28 (schlechtester Wert). Die Patienten derjenigen Klinik, die hauptsächlich 
Berufsgruppen mit körperlich anstrengender Arbeit versorgte, hate höhere Werte als die zwei anderen Kliniken. Die Zeit seit Operation und die Albuminkonzentration korrelierten negativ mit der Edinburgh Rehabilitation Status Skala (ERSS), während Dyspepsie, Dysphagie und Reflux positiv korrelierten. In einer univariaten Analyse zeigten zunehmende Abweichungen bei der intestinalen Endoskopie eine positive Korrelation mit der Edinburgh Rehabilitation Status Skala. In Kapitel IX wurden die Strategien der Krankheitsverarbeitung von 50 Patienten nach kurativer totaler Gastrektomie, die auf die Einladung des PSychologen reagiert hatten, mit einem standardisierten Fragebogen erfaßt. Das Feld ComplianceStrategie und Antvertrauen zeigte höhere Werte als alle anderen Felder $(\mathrm{p}<0.0001)$. Die Strategien Selbsternutigung und Relativierung durch Vergleich hatten höhere Werte als alle anderen Felder $(p=0.0001)$, mit Ausnahme vom Feld Compliance-Strategie und Arztvertrauen. Problemanalyse und Lösungsverhalten und Hedonismus wurden signifikant höher $(p=0.0003)$ bewertet als Kognitive Vermeidung und Dissimulation als auch die anderen sieben nicht erwähnten Felder. Die Felder Compliance-Strategie und Arztvertranen, Hedonismus, Regressive Tendenz, Relativierung durch Vergleich, und Selbstermutigung hatten mindestens zehn Patienten (20\%) oberhalb des Mittelwertes plus einer Standardabweichung verglichen mit einer kranken Kontrollgruppe aus der Literatur, während nur das Feld Gefühlskontrolle/sozialer Rückzug zehn Patienten unterhallb dieses Vergleichswertes hatte. Es gab eine positive Korrelation des Feldes Hedonismus mit der Zeit, die seit der Operation verstrichen war $\left(\mathrm{r}^{2}=0.5, \mathrm{p}<0.0001\right)$.

Tumorfreie Patienten nach totaler Gastrektomie zeigen hauptsächlich aktive und problem-orientierte Krankheitsverarbeitung. Falls der behandelde Arzu/Ärztin diese Strategien erkennt, kann die postoperative Rehabilitation wahrscheinlich noch weiter verbessert werden.

In Kapitel X wird unter Berücksichtigung der gesamten Ergebnisse dieser Studien diskutiert, welche Faktoren für die Nahrungsmittelmalassimilation nach totaler Gastrektomie relevant sind und was das postoperative medizinisch-soziale Funktionieren beeinträchtigt.

Eine symptombedingte erniedrigte Kalorienaufnahme und/oder eine pancreaticocibale Asynchronie scheinen die Hauptursache der Mangelnährung nach totaler Gastrektomie zu sein.

Die sozialen Umstände und speziell die Arbeitsplatzsituation der Patienten, die Zeitspanne nach Operation, sowie die Symptome Dyspepsie, Dysphagie und Reflux sind unabhängige Faktoren, die das medizinisch-soziale Funktionieren nach totaler Gastrektomie bestimmen.

Es bleibt zu untersuchen, ob eine Verlängerung der Dünndarmtransitzeit bei Patienten mit Steatorrhoe nach Gastrektomie diese vermindert. Eien andere Aufgabe ist es, die Dyspepsie nach Gastrektomie näher zu beschreiben, um entsprechende therapeutische Maßnahmen zu entwickeln. 
Dankwoord 


\section{Dankwoord}

Het werd mij verteld, dat het dankwoord het meest gelezen deel van een proefschrift is. Dit wetende, wordt het ook een lastig te schrijven gedeelte, ondat men toch niet alle betrokken personen kan noemen. Zoals velen voor mij, wil ik dan ook eerst iedereen die aan de studie heeft meegedaan van harte bedanken, ook al is dat wat onpersoonlijk.

Enkele personen wil ik toch bij name noemen.

Hooggeleerde Stockbrügger, als mijn promotor had je vanaf het begin de touwtjes van de studie vast in handen. Je was het hoofd achter het hele onderzoek. Wat voor mij als een kleine studie in Bad Kissingen was begonnen, is door jouw consequente begeleiding en sturing behoorlijk gegroeid totdat dit proefschrift is ontstaan. Beste Reinhold, als vriend was je altijd aanspreekbaar en hebt de meeste "üps en douns", zoals ze hier in Nederland zeggen, meegemaakt en meegeleefd. Zowel voor het eerste als voor het tweede punt mijn hartellijke dank.

Zeergeleerde Armbrecht, beste Ulrich, toen ik in Bad Kissingen kwam, stond alles kant en klaar om met deze studie te starten. Dat was voor een groot deel jouw verdienste. Jouw directe theoretische en praktische begeleiding was onmisbaar - zowel bij de interpretatie van de een of andere test als ook bij sommige operatie verslagen.

Mijn co-auteurs Dr D Rosemeyer, Prof Dr W Zilly, Prof Dr B Schneider, Drs A Volovics en $\mathbb{H H}$ Theissen wil ik danken voor de inzet zowel bij de data verzameling als ook bij de interpretatie van de gegevens.

De leden van de beoordelingscommissie, Prof Dr G Kootstra, Prof Dr ir. WHM Saris, Prof Dr H Abrahamsson, Prof Dr P Pop, Prof Dr JPMA Smout bedank ik voor hun bereidwilligheid het manuscript te lezen en voor het geven van waardevolle adviezen.

Prof Dr Kruseman en Prof Dr HFP Hillen, mijn opleiders voor Interne Geneeskunde in Maastricht, bedank ik hartelijk voor hun inzet.

Mijn mentor Karel Leunissen wil ik bedanken voor enkele interessante gesprekken. die ik belangrijker vond als ik destijds misschien heb laten zien.

De leden van de afdeling diëtiek in Bad Kissingen onder de leiding van Mv. Heide wil ik graag bedanken voor hun inzet bij de verzaneling van de voedings-gegevens.

De werkgroep gastroenterologie Maastricht had met dit onderzoek alleen indirect te doen omdat de data verzameld waren toen ik hier kwam. Mijn dank is dan ook voornamelijk voor de prettige samenwerking aan Wim, Robert-Jan, Rob, Maurice, Erik. Ingrid, Peter, Ardi, Silvia, Bertine, en Gaby. Boudewijn en Ton wil ik graag extra noemen - met de ene zou ik nog graag willen koken en met die andere nog een voetbal finale zien. 
Graag wil ik nog noemen mijn langdurige kamergenoot Wubbo Mulder met wie in ontspannen discussies de meeste problemen van de wereld zijn opgelost.

Evelyn Pijpers, wriendin, paranimf en Oxfordian, wil ik graag danken voor het vele leuke gesprekken. Motivatie dieptepunten heb je opgevangen zodat het toch nog goed is gekomen. I $\mathrm{k}$ ben zeker dat jouw toekomst in de kliniek en ook in de wetenschap witstekend zal lopen.

Marie-Noël Janssen, wil ik danken woor de taalcorrecties (this is business) maar ook en vooral voor je voortdurende en besmettelijke vrolijkheid (this is personal).

Tiny Wouters heeft -zoals bij de meeste pomovendi van het a $\mathrm{M}$ voor mij- in een alomvattende professionele greep het manuscript "drukklaar" gemaakt.

En กแ.
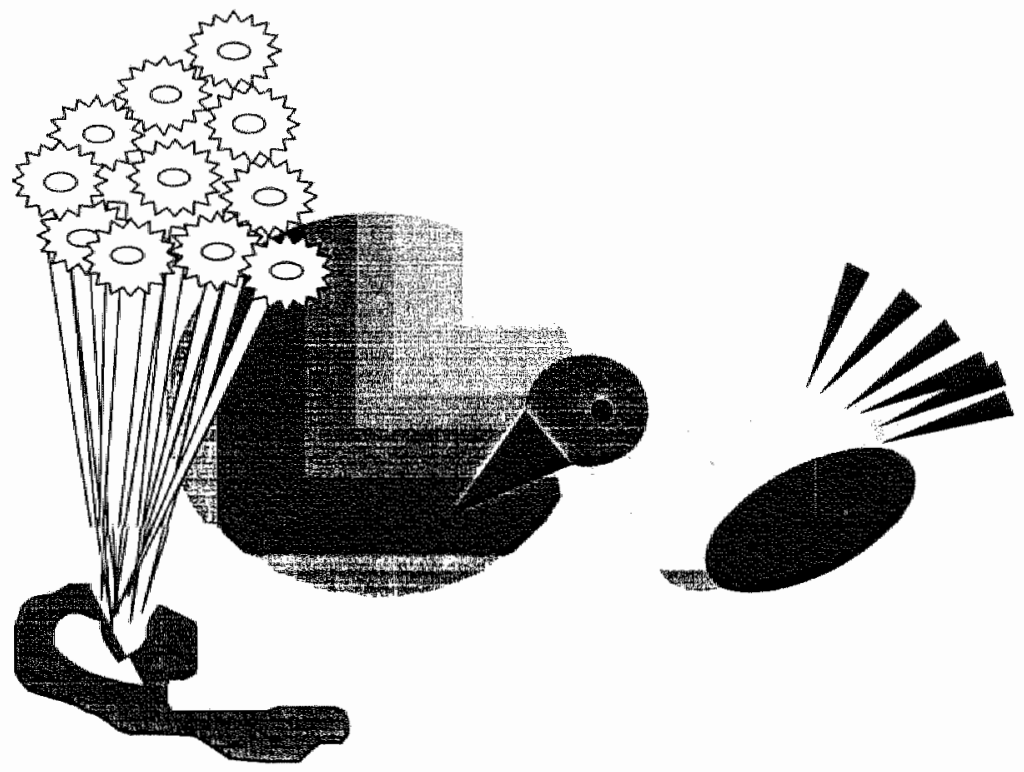
Curriculum Vitae 


\section{Curriculum Vitae}

Robert Brägelmann

$1960 \quad$ Geboren te Vechta, Duitsland

1977-1978 Uitzending Verenigde Staten (YFU), Portand, Michigan

1981 Eindexamen Gymnasium, Gymnasium Antonianum Vechta

1981-1982 Studie Engels en Geschiedenis, Universiteit Frankfurt am Main

1982-1984 Studie Geneeskunde, Rijks Universitair Centrum Anwerpen.

1984-1985 Studie Geneeskunde, Medizinische Hochschule Hannover

1985-1986 Studie Geneeskunde, Universiteit Frankfurt am Main

1989-1992 Arts-assistent interne geneeskunde Marbachtalklinik

Chefarzt Prof Dr R W Stockbrügger

Chefarzt Dr Dr U Armbrecht

1992-1993 Arts-assistent interne geneeskunde Diakonissenkrankenhaus Witten Chefarzt Prof Dr Gallenkamp

1993-1994 Arts-assistent interne geneeskunde Kreiskrankenhaus Lichtenfels Chefarzt Prof Dr Atzpodien

1994- Arts-assistent interne geneeskunde Academisch Ziekenhuis Maastricht Prof Dr HFP Hillen

30-06-1996 Specialist Interne Geneeskunde 